\section{Pacific Northwest}

National Laboratory

Operated by Battelle for the

U.S. Department of Energy

\title{
Laboratory Testing of Bulk Vitrified and Steam Reformed Low-Activity Waste Forms to Support a Preliminary Risk Assessment for an Integrated Disposal Facility
}
B. P. McGrail
J. L. Steele
E. M. Pierce
A. T. Owen
H. T. Schaef
D. M. Wellman
E. A. Rodriguez

September 2003

Prepared for the U.S. Department of Energy

under Contract DE-AC06-76RL01830 


\title{
DISCLAIMER
}

This report was prepared as an account of work sponsored by an agency of the United States Government. Neither the United States Government nor any agency thereof, nor Battelle Memorial Institute, nor any of their employees, makes any warranty, expressed or implied, or assumes any legal liability or responsibility for the accuracy, completeness, or usefulness of any information, apparatus, product, or process disclosed, or represents that its use would not infringe privately owned rights. Reference herein to any specific commercial product, process, or service by trade name, trademark, manufacturer, or otherwise does not necessarily constitute or imply its endorsement, recommendation, or favoring by the United States Government or any agency thereof, or Battelle Memorial Institute. The views and opinions of authors expressed herein do not necessarily state or reflect those of the United States Government or any agency thereof.

\section{PACIFIC NORTHWEST NATIONAL LABORATORY operated by BATTELLE MEMORIAL INSTITUTE for the UNITED STATES DEPARTMENT OF ENERGY under Contract DE-AC06-76RLO 1830}

\author{
Printed in the United States of America
}

$$
\begin{gathered}
\text { Available to DOE and DOE contractors from the } \\
\text { Office of Scientific and Technical Information, } \\
\text { P.O. Box 62, Oak Ridge, TN 37831-0062; } \\
\text { ph: (865) 576-8401 } \\
\text { fax: (865) 576-5728 } \\
\text { email: reports@adonis.osti.gov }
\end{gathered}
$$

Available to the public from the National Technical Information Service, U.S. Department of Commerce, 5285 Port Royal Rd., Springfield, VA 22161 ph: (800) 553-6847 fax: $(703) 605-6900$

email: orders@ntis.fedworld.gov

online ordering: http://www.ntis.gov/ordering.htm 


\section{Laboratory Testing of Bulk Vitrified and Steam Reformed Low-Activity Waste Forms to Support A Preliminary Risk Assessment for an Integrated Disposal Facility}
B. P. McGrail
E. M. Pierce
H. T. Schaef
E. A. Rodriguez
J. L. Steele
A. T. Owen
D. M. Wellman

September 2003

Prepared for

the U.S. Department of Energy

under Contract DE-AC06-76RLO 1830

Pacific Northwest National Laboratory

Richland, Washington 99352 


\section{Summary}

Low-activity tank wastes will be generated during cleanup of high-level radioactive tank wastes on the Hanford site. The low-activity tank waste will be among the largest volumes of radioactive waste within the U.S. Department of Energy (DOE) complex and is one of the largest inventories of long-lived radionuclides planned for disposal in a low-level waste facility. The Department of Energy's Office of River Protection is evaluating several options for immobilization of low-activity tank wastes for eventual disposal in a shallow subsurface facility at the Hanford Site. A significant portion of the waste will be converted into low-activity waste (LAW) glass with a conventional Joule-heated ceramic melter. In addition, three supplemental treatment processes are presently under consideration by the DOE to treat wastes in selected tanks with the goal of accelerating the overall cleanup mission at the Hanford site. These are: 1) bulk vitrification (BV), 2) cementation or the cast stone (CS) process, and 3) steam reformation (SR). The DOE is expected to select by October 2003 one or more of these supplemental treatment technologies for more detailed evaluation. As part of the selection process, a preliminary risk assessment is being performed to evaluate the impacts of the disposal facility on public health and environmental resources.

The purpose of this report is to document the laboratory testing that was conducted on BV and SR waste forms to supply the input parameters needed for reactive chemical transport calculations with the Subsurface Transport Over Reactive Multiphases (STORM) code. This same code was used to conduct the 2001 ILAW performance assessment. The required input parameters for BV and SR waste forms are derived from a mechanistic model that describes the effect of solution chemistry on contaminant release rates. The single-pass flow-through test is the principal method used to obtain these input parameters, supplemented by product consistency test measurements and physical property measurements. 


\section{Contents}

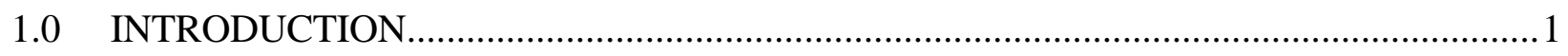

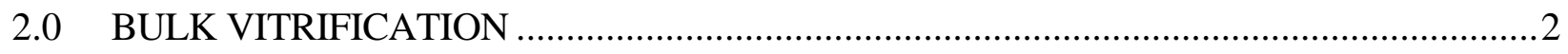

2.1 Froth-Layer Characterization ....................................................................................

2.1.1 Pore Size Distribution........................................................................................ 3

2.1.1.1 X-ray Microtomagraphy (XMT) ………………………………....

2.1.1.2 Froth-Layer Glass Surface Area ……………………...........................

2.1.2 Volatilized Pertechnetate Salt Fraction.....................................................................

2.1.2.1 Re Volatilization Fraction......................................................................... 6

2.1.2.2 ${ }^{99} \mathrm{Tc} / \mathrm{Re}$ Volatilization Ratio ................................................................. 6

2.1.2.3 Swept Volume Fraction.........................................................................

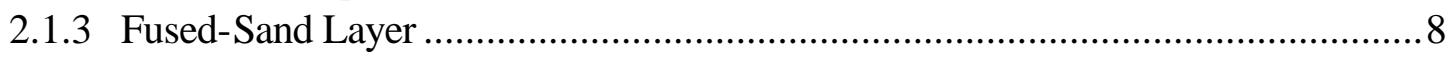

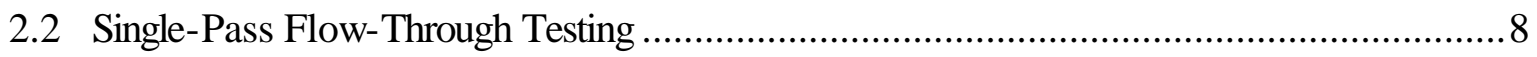

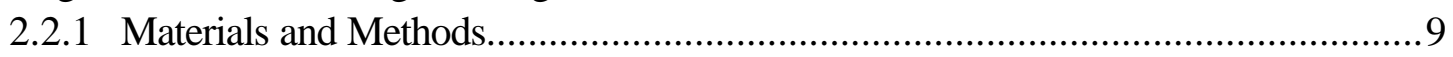

2.2.1.1 Bulk Composition Analysis .................................................................

2.2.1.2 Sample Preparation .......................................................................... 10

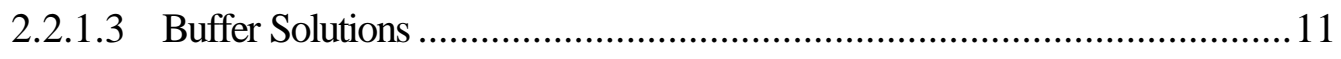

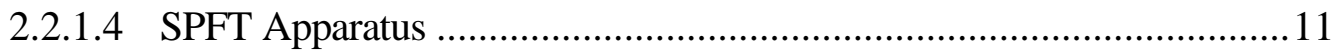

2.2.1.5 Dissolution Rate and Error Calculations ................................................. 12

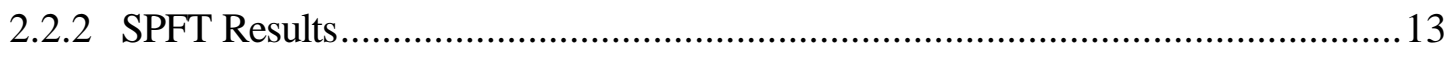

2.2.2.1 Crucible Melt BV Glass BKV1 (ASCM-01) ……………………........ 14

2.2.2.2 Comparison of Rate Law Parameters to EST-01

and LST-02 BV Glass Samples..................................................................... 18

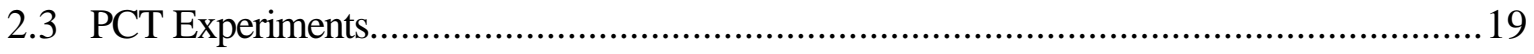

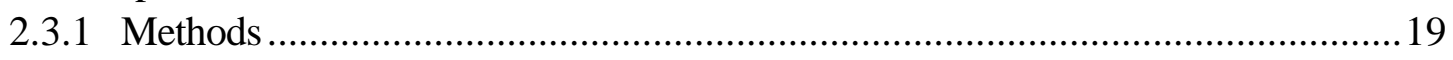

2.3.2 Results for BKV1 Glass ............................................................................19

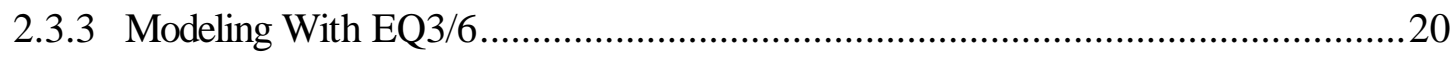

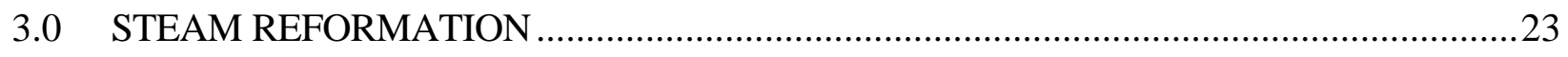

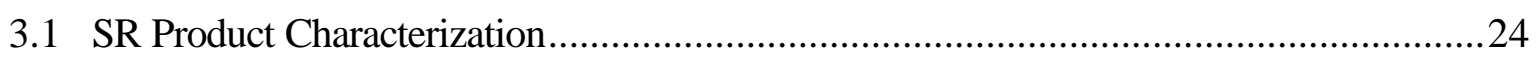

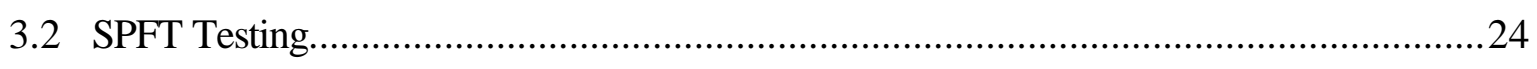

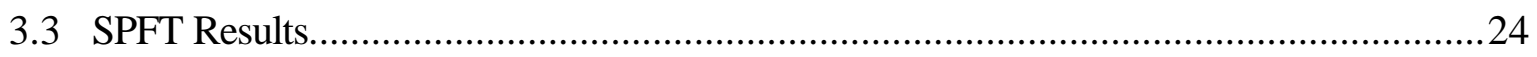

3.4 Rate Law Parameter Estimation for Nepheline and Nosean............................................26

3.5 Nosean and Nepheline Solubility Product...................................................................2

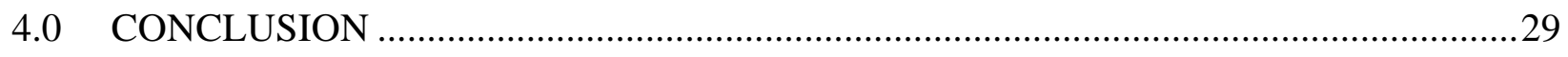

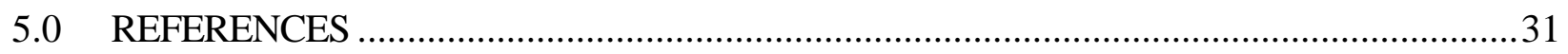

6.0 APPENDIX A. BULK VITRIFIED PRODUCT CHEMICAL ANALYSIS...........................34

7.0 APPENDIX B - BULK VITRIFIED GLASS SPFT TEST DATA .......................................... 37

8.0 APPENDIX C - STEAM REFORMER SPFT TEST DATA ……………………................73 


\section{Figures}

Figure 1. Photograph of LST-02 Block After Removal of Steel Forms........................................2

Figure 2. Picture of Froth Layer Sample From Large Scale Test \#2 _............................................2

Figure 3. Picture of Froth Layer Sample From EST-01 ......................................................

Figure 4. Picture of Edge Piece Broken Off From Near the East Electrode

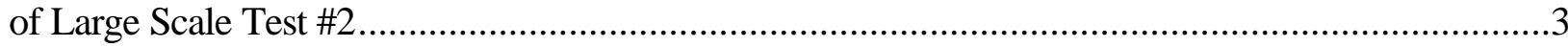

Figure 5. Digital Photograph of the XMT System.................................................................4

Figure 6. CT Image of BV Froth Layer Sample ...................................................................

Figure 7. Pore Size Distribution as Determined from CT Image Analysis........................................5

Figure 8. X-ray Diffraction Pattern of $\mathrm{SiO}_{2}$ Polymorphs as a Function of Depth and Relative Intensity.8

Figure 9. Quantitative X-ray Diffraction Data of $\mathrm{SiO}_{2}$ Polymorphs as a Function of Depth

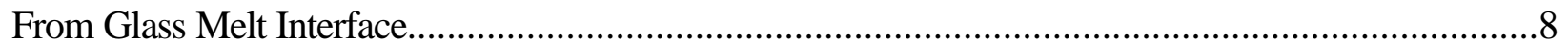

Figure 10. Schematic of the Single Pass Flow-Through (SPFT) Apparatus ....................................12

Figure 11. Normalized B Release Rate as a Function of $\mathrm{pH}$ and Temperature...............................14

Figure 12: Na Ion Exchange Rate as a Function of Solution $\mathrm{pH}$ and Temperature..........................15

Figure 13. Na Ion Exchange Rate Versus Reciprocal Temperature for $\mathrm{SiO}_{2}(\mathrm{aq})$ activity

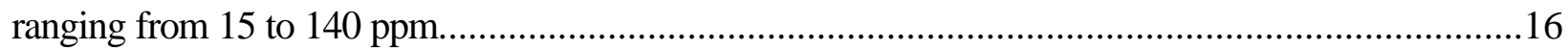

Figure 14. Normalized Release Rate with Respect to B and $\mathrm{Na}$ Versus $\mathrm{SiO}_{2}$ (aq) Activity

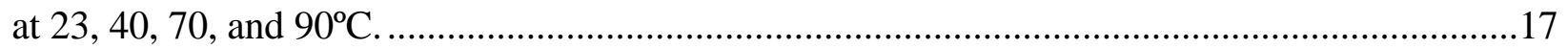

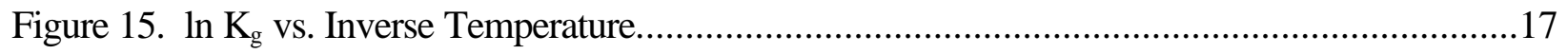

Figure 16: Comparison of Normalized B Release Rates as a Function of $\mathrm{pH}$ and Temperature for Each Glass Sample Tested.................................................................................................. 18

Figure 17: Comparison of $\ln \mathrm{K}_{\mathrm{g}}$ as a Function of Temperature for BKV1, BKVX, and BKV4........18

Figure 18. PCT-B Results for BKV1, BKV4, and BKV5 Glasses............................................19

Figure 20: Predicted Paragenetic Sequence of Alteration Phases Formed During the Reaction of

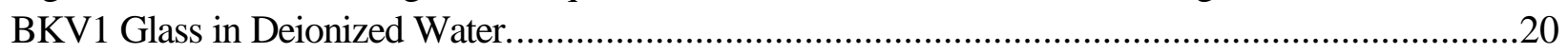

Figure 19: Comparison of PCT Solution Concentration Data (symbols) with the Solution Composition Calculated with the EQ3/6 Code ..................................................................................20

Figure 21. Optical Photograph of SCT02-098 Particle. Black particles are magnetite....................23

Figure 22. Normalized Release Rate as a Function of Time and Temperature in SPFT Experiments ..25

Figure 23. Normalized Release Rate as a Function of Temperature in SPFT Experiments

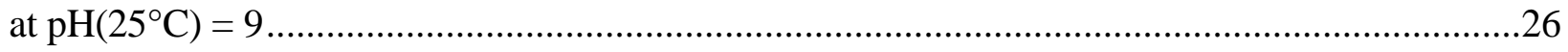




\section{Tables}

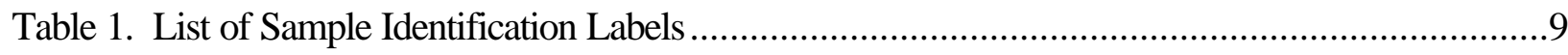

Table 2. Calculated Thermal Cool down Profile for the Crucible Melt Sample and a AMEC Large

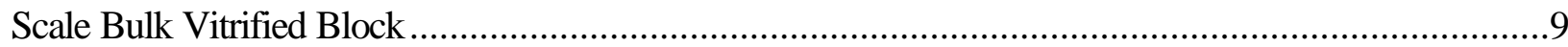

Table 3. "Normalized Chemical Composition of Bulk Vitrified Glass Samples with WTP Glass Sample LAWA44 for Comparison ........................................................................10

Table 4. Composition of Solutions Used in SPFT Experiments....................................................11

Table 5. Estimate of the Pseudo-Equilibrium Constants for BKV1 as a Function of Temperature. .....17

Table 6: Estimate of the Pseudo-Equilibrium Constants for BKVX and BKV4 as a Function of

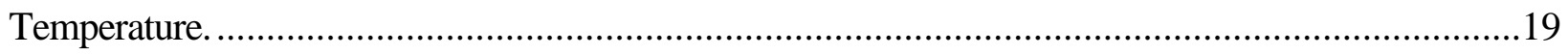

Table 7: Secondary Phase Reaction Network for BKV1 Glass ...............................................21

Table 8. Composition of Solution Used in SPFT Experiments SR Product.....................................24

Table 9. Thermodynamic Data Used for Calculating Temperature-Dependence

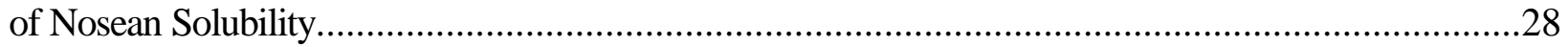

Table 10. Temperature-dependent Solubility Constants for Nosean............................................28 


\section{Quality Assurance}

The work described in this report was performed under the PNNL Nuclear Quality Assurance Requirements Description (NQARD) procedures in accordance with the Supplemental Technologies Support Program, Tank Waste Support Quality Assurance Plan Rev. 2. These project quality assurance procedures and the project QA plan are compliant with the national standard ASME/NQA-1as required in the project sponsor's statement of work. Testing documented in this report was performed in accordance with Test Plan: Kinetic Parameter Measurements on "Bulk Vitrified and Steam Reformed Immobilized Low-Activity Waste Using the Single-Pass Flow-Through Test Method," 44832-200301, Rev. 0, and "Test Plan: Product Consistency Test Measurements on Bulk Vitrified Low-Activity Waste Simulants," 44832-2003-02, Rev. 1. However, some of the project work was conducted under the PNNL Standards Based Management System quality program or the quality programs implemented by others. This work included:

- $\quad$ software applications

- subcontracted chemical analysis

- sample collection, data, and procedures provided by or with the assistance of non-project staff

- physical property analysis of froth layer samples obtained from large-scale test \#2. 


\subsection{Introduction}

The purpose of this report is to document the results from laboratory testing that was conducted to support a preliminary risk assessment for two waste forms that are being considered for supplemental treatment Hanford low-activity tank waste: glass produced by a bulk vitrification (BV) process, and a polycrystalline ceramic produced by a steam reformation (SR) process. The laboratory testing information presented in this document represents the execution of a testing strategy that was outlined previously by McGrail et al. (2003a). To limit duplication, only very limited background information is provided in this report. The reader should refer to the prior strategy report (MCGRAIL et al., 2003a) for details on the background and rationale for the testing program described here.

Briefly, low-activity wastes (LAW) at Hanford will be converted into glass at a Waste Treatment Plant (WTP) with a conventional slurry-fed, Joule-heated ceramic melter. However, in 2002, the U.S. Department of Energy (DOE) began implementation of an accelerated cleanup plan for the Hanford Site designed to shorten the overall cleanup by at least 35 years. A key element of the accelerated cleanup plan is a strategic initiative for acceleration of tank waste treatment by increasing the capacity of the WTP and using supplemental technologies for waste treatment and immobilization for as much as 70\% of the LAW (DOE, 2002). Three supplemental treatment options for immobilization of low-activity tank waste are being evaluated: 1) bulk vitrification (BV), 2) cementation or the cast stone (CS) process, and 3) steam reformation (SR). Each supplemental treatment technology will be evaluated against predetermined criteria in areas such as safety, environmental protection, schedule, cost, operability, and interfaces. The initial technology selection is scheduled to be completed by October 30, 2003.

The environmental protection aspects of any LAW forms are evaluated through a performance assessment, which is a document that describes the long-term impacts of the disposal facility on public health and environmental resources. Because of time and funding constraints, a full performance assessment for all three supplemental waste forms could not be carried out. Instead, a risk assessment method was selected that is acknowledged to be less rigorous and detailed than a performance assessment but of sufficient technical rigor to support a decision-making process for selection among bulk vitrification, cementation, and steam reformation technologies for treating Hanford LAW.

The Pacific Northwest National Laboratory (PNNL) was tasked by CH2M Hill Hanford Group, Inc. to perform the testing outlined in the strategy document of McGrail et al. (2003a) for the BV and SR waste forms. The Center for Laboratory Science at Columbia Basin College (Pasco, WA) was tasked to conduct the required testing for the CS waste form. Detailed discussion of the computer simulations and calculational results of contaminant release rates for all three supplemental treatment technologies are documented in the report by Mann et al. (2003).

The testing discussed in this report should not be interpreted as either sufficient or comprehensive to complete a performance assessment for an Integrated Disposal Facility (IDF) containing these waste forms. We expect development of a testing strategy and testing program will be pursued if one or more of the supplemental treatment technologies are selected for further development. 


\subsection{Bulk Vitrification}

Bulk vitrification (AMEC Earth \& Environmental, Inc.) is a modification to the in situ vitrification (ISV) process developed for remediation of buried wastes and contaminant plumes in soils (TIXIER et al., 1991; LUEY and SEILER, 1995). An in-container vitrification process has been designed in which LAW, soil, and glass forming chemicals are mixed, dried, and then melted at about $1500^{\circ} \mathrm{C}$ by electrical resistance heating (KIM et al., 2003). Graphite flakes are added to the mix to form a conductive path for melt initiation. Current is supplied by two graphite electrodes imbedded in the batch. The high-temperature glass melt is kept insulated from the steel container by lining the container walls with a $15 \mathrm{~cm}$ (6 in) of Lane Moun-

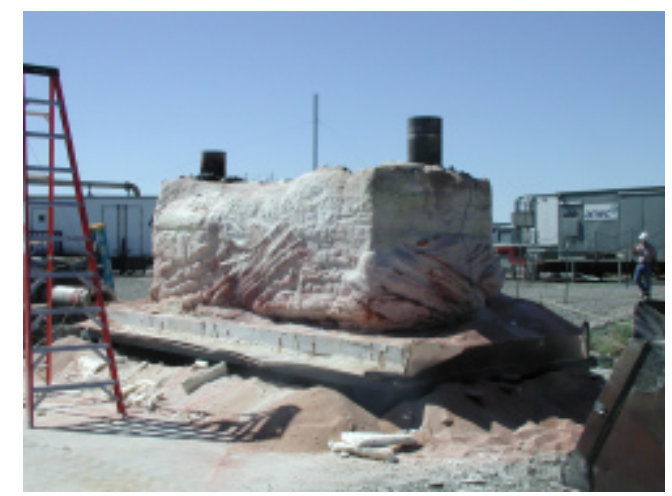

Figure 1. Photograph of LST-02 Block After Removal of Steel Forms. East electrode is on the right. tain \#16 quartz sand. Gases generated during the process are vented to an off-gas treatment system. Figure 1 shows the configuration of the BV block immediately after the steel forms were removed from the sides.

The BV process does not produce a waste form that can be characterized by a single set of physical and chemical properties. The product is heterogeneous with complex interfaces. We have elected to divide the BV product into three distinct lithological units: 1) scoria layer at the top, 2) fusedsand layer on the four sides and bottom, and 3) bulk glass. Certainly, additional divisions could be assigned but the three lithologies are believed to adequately represent the most significant features.

The top of the block is a so-called "froth layer". The froth layer is analogous to the vesicular tops of basalt lava flows formed by gas bubbles trapped in the melt (REIDEL et al., 2002). A photo of a froth-layer sample obtained from large-scale test \#2 (LST-02) of the BV process is shown in Figure 2. The froth layer has higher porosity and hence available surface area for glass dissolution and contaminant release than the bulk of the melt. Hence, characterization of the physical properties of this layer was needed (see Section 2.1 for details).

We also examined scoria samples from an engineeringscale test (\#1) of the BV process (KIM et al., 2003). Several samples were noted as being coated with a white precipitate, as shown in Figure 3. X-ray diffraction analyses positively

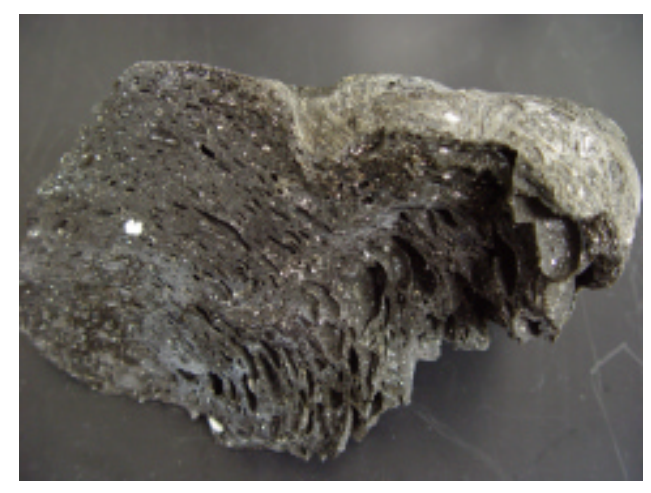

Figure 2. Picture of Froth Layer Sample From Large Scale Test \#2

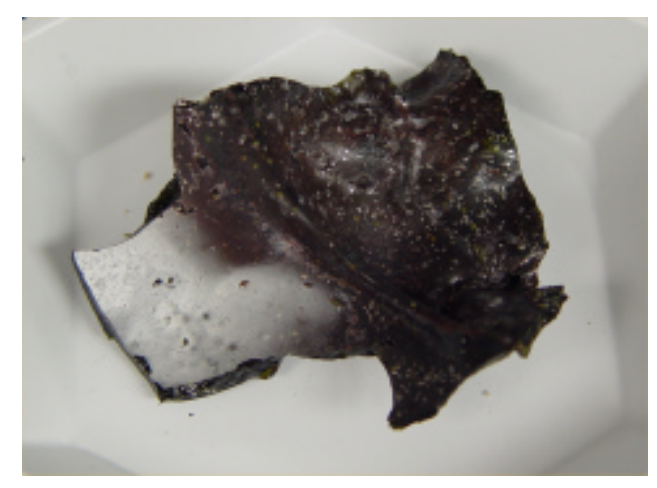

Figure 3. Picture of Froth Layer Sample From EST-01 
identified $\mathrm{KReO}_{4}$ as one of several crystalline phases making up the white coating. Because $\mathrm{Re}$ was used in the EST-01 test as a non-radioactive chemical analog for ${ }^{99} \mathrm{Tc}$, the discovery of a discrete $\mathrm{Re}$ bearing phase as a soluble salt had important implications for both product testing and risk assessment calculations. The method we used for estimating the amount of Tc that would be present in a soluble salt phase is documented in Section 2.1.2.

During the BV process, partial dissolution of the insulating layer of quartz sand occurs into the BV melt. This tends to raise the $\mathrm{SiO}_{2}$ content of the final product glass from the target. Heating into the temperature range of the $\mathrm{BV}$ melt $\left(\approx 1500^{\circ} \mathrm{C}\right)$ also causes phase changes in the quartz sand; hightemperature, low-pressure $\mathrm{SiO}_{2}$ polymorphs identified in samples taken from large-scale tests of the process include several forms of tridymite and cristobalite. Consequently, five sides of the BV box contain a sequence of layers that generally progress from the outer edge towards the melt as follows:

$$
\alpha \text {-quartz } \rightarrow \text { tridymite } \rightarrow \text { cristobalite } \rightarrow \text { glass melt }
$$

Figure 4 shows the layer structure observed along an edge broken off near the East electrode from the LST-02 test. The yellow coloration was identified as zincite $(\mathrm{ZnO})$ that apparently formed from vaporization of a piece of galvanized steel flashing that was placed near the top of the melt. Details on the characterization of samples removed from the "fused-sand" layer are provided in Section 2.1.

The last lithological unit is the bulk glass. We have made no attempt in this work to quantify any heterogeneity that may exist in the physical or chemical properties of the bulk glass. A grab sample was obtained from the proximity of the middle of the LST-02 block; this sample was used for comparison with sam-

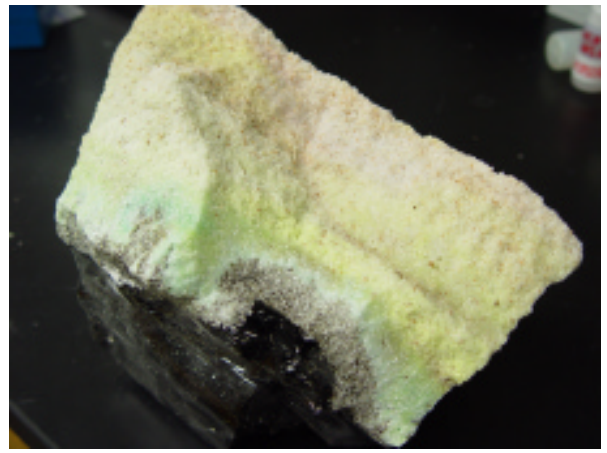

Figure 4. Picture of Edge Piece Broken Off From Near the East Electrode of Large Scale Test \#2 ples from the EST-01 test and with a crucible melt sample.

In the next section, we discuss the measurements performed to characterize the physical properties of the BV froth layer. That discussion is followed by a discussion of the chemical characterization and dissolution testing performed on the samples, and the results.

\subsection{Froth-Layer Characterization}

\subsubsection{Pore Size Distribution}

Characterization of the pore size distribution in the froth layer is needed for two purposes: 1) computation of the glass surface area per unit volume, and 2) computation of hydraulic properties for the froth layer. Due to time limitations, only a few grab samples were subjected to detailed analyses. Consequently, the values reported here are representative of the few samples that were analyzed and should not be interpreted as a complete or even adequate representation of the froth layer properties.

The determination of the average pore size distribution and overall porosity was accomplished through the use of an x-ray microtomography system available at PNNL. 


\subsubsection{X-ray Microtomagraphy (XMT)}

$\mathrm{X}$-ray microtomography provided a novel way to characterize the froth layer glass properties. Characterization was principally done on a piece of froth-layer glass broken off the sample shown in Figure 2. This sampled was labeled BKV5. The XMT system at PNNL, shown in Figure 5, is an ACTIS 200/160 KXR unit manufactured by Bio-Imaging Research, Inc. The $\mathrm{X}$-ray generator is a Kevex KM16010E-A X-ray tube with spot sizes of $10,20,65,250 \mu \mathrm{m}$ at power levels 5 , 10,50 , and 160 watts. The microfocus X-ray source allows variable slice widths over a nominal range of 10

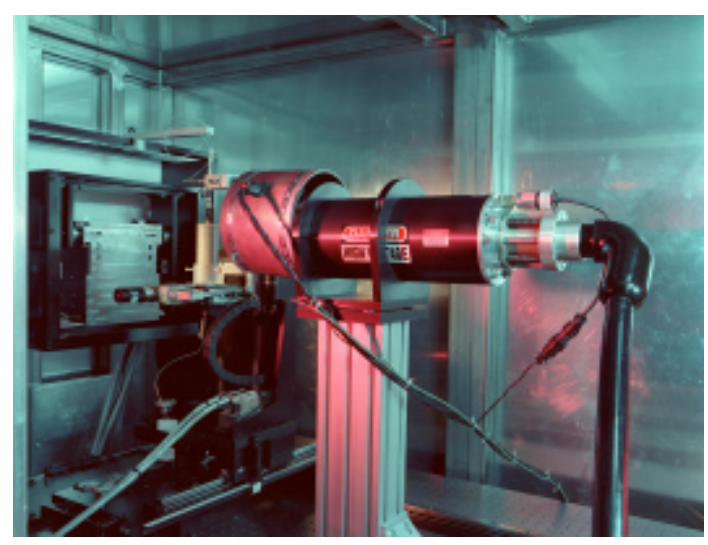

Figure 5. Digital Photograph of the XMT System to $150 \mu \mathrm{m}$ and can achieve resolution in the focal plane of one one-thousandth of the object diameter. A computer-controlled sample manipulator with a $75-\mathrm{mm}$ diameter turntable allows $365^{\circ}$ of continuous rotation and a maximum vertical travel of $150 \mathrm{~mm}$ The detection system is a BIR RLS 2048-100 discrete element solid-state detector system consisting of gadolinium oxysulfide scintillator and EG \& G Reticon photodiodide arrays. The system produces cross-sectional (CT) images and digitized radiographs (DR). A computer data acquisition, instrument control, and image reconstruction system with ACTIS+ software provides X-ray and sample manipulation control in addition to CT and CT MultiPlaner (MPR-3D) imaging. Two-dimensional computed tomographic (CT) images are displayed using 2562, 5122, or 10242 pixels, each at 12 bits (4096 contrast levels).

Sample imaging began once the $\mathrm{X}$-ray generator equilibrated for at least 30 minutes at power settings of $160 \mathrm{KeV}$ and $0.3 \mathrm{~mA}$. The sample was scanned using a large focal spot size of $250 \mu \mathrm{m}$, target power of 160.0 $\mathrm{keV}$, and a current of $1.0 \mathrm{~mA}$ Twenty scans with a slice thickness of $0.1 \mathrm{~mm}$ each were taken in increments of 2 $\mathrm{mm}$ moving in a vertical direction from the bottom to the top of the sample. The sample was scanned in a full $360^{\circ}$ rotation with a total of 2000 pictures captured on each section. The pictures were compiled and integrated to reconstruct a single two-dimensional computed tomographic image at each $2 \mathrm{~mm}$ sample interval. A typical CT scan is

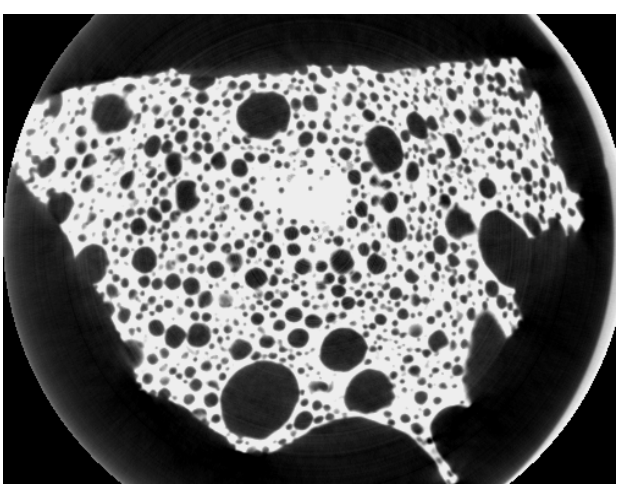

Figure 6. CT Image of BV Froth Layer Sample shown in Figure 6.

Clemex Vision PE 3.5 (Clemex Technologies Inc., Quebec, Canada) image analysis software was used to process the $2 \mathrm{D}$ images and determine the porosity of each glass slice. The raw images were loaded into the software and an automated routine was established to ensure invariant image analysis of all sample slices. The 2D images were optimized to produce even gray levels within each phase and to increase contrast. Each image was threshold processed by grouping pixels within a restricted gray level range into editable bitplanes representing the background, glass, and pore space. The bitplanes were subsequently shaded red, green and blue, respectively and computer analyzed. Digital area analysis determined the number of pores, their respective size fractions, and the total porosity. All of the image 
analysis data was combined and normalized to produce a pore size population distribution, which is given in Figure 7. The total porosity $(\varepsilon)$ was computed from averaging the values from $20 \mathrm{CT}$ images. Total porosity was 0.36 \pm 0.08 . This value is in excellent agreement with the 0.32 value for determined gravimetrically.

\subsubsection{Froth-Layer Glass Surface Area}

The pore size distribution data given in Figure 7 were fit to a log-normal distribution of the form

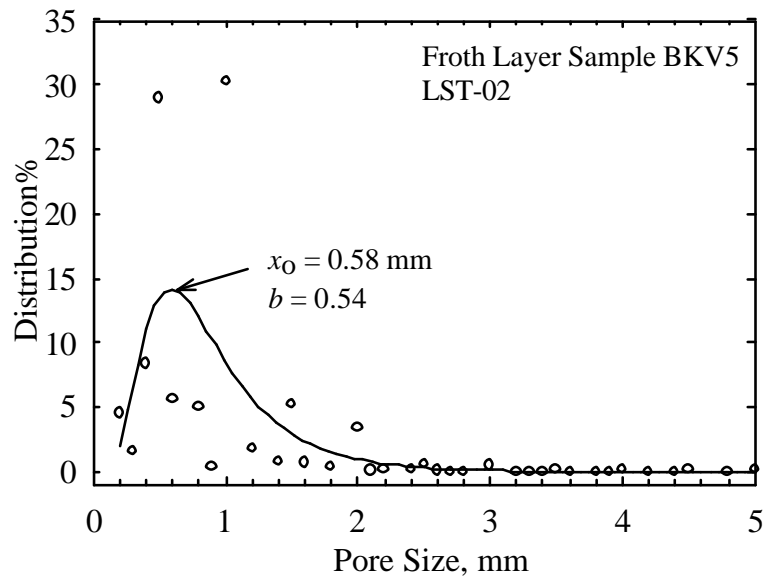

Figure 7. Pore Size Distribution as Determined from CT Image Analysis

$$
p_{p}(x)=\frac{\exp \left(-\frac{\left[\ln (x)-\mathrm{x}_{\mathrm{o}}\right]^{2}}{2 b^{2}}\right)}{b x \sqrt{2 \pi}}
$$

where $x_{\mathrm{o}}$ is the mean pore size diameter and $b$ is the shape parameter. The best fit parameters were $b=0.535$, and $x_{0}=0.581 \mathrm{~mm}$. The total pore volume in a scoria sample of radius $r$, where $r>\mathrm{x}_{0}$, is then given by

$$
\varepsilon V=n \int_{x_{\min }}^{\infty} V_{p}(x) p_{p}(x) d x=n \int_{x_{\min }}^{\infty} \frac{4}{3} \pi(x / 2)^{3} \frac{\exp \left(-\frac{\left[\ln (x)-\mathrm{x}_{\mathrm{o}}\right]^{2}}{2 \mathrm{~b}^{2}}\right)}{b x \sqrt{2 \pi}} d x
$$

where $n$ is the total number of pores, and $V_{p}$ is the volume of each pore with average diameter $x$. The total glass surface area associated with the pores $\left(A_{p}\right)$ is then given by

$$
A_{p}=n \int_{x_{\min }}^{\infty} \pi x^{2} p_{p}(x) d x
$$

As the pore surface area will be much greater than geometric surface area for any sample of diameter significantly larger than the mean pore diameter, we neglect the geometric surface area in computing the total surface area. The STORM simulator (BACON et al., 2000) requires surface area of a reactant normalized to the volume of the reactant. Consequently, the value of interest is

$$
A_{r}=\frac{A_{p}}{(1-\varepsilon) V}=\frac{6 \varepsilon \int_{x_{\min }}^{\infty} x^{2} p_{p}(x) d x}{(1-\varepsilon) \int_{x_{\min }}^{\infty} x^{3} p_{p}(x) d x}
$$


Setting $\varepsilon=0.32, x_{\mathrm{o}}=0.581 \mathrm{~mm}$, and $b=0.535$ in Equation (4), we find $A_{r}=771 \mathrm{~m}^{2} / \mathrm{m}^{3}$.

\subsubsection{Volatilized Pertechnetate Salt Fraction}

An estimate of the amount of Tc that would get volatized and condensed as a soluble salt in BV froth layer was calculated as described in this section. The estimate was based largely on a single measurement conducted on the froth layer samples from the LS-02 test. Changes in the process, such as filling each box twice as full of waste/soil mix may impact the volatilization fraction estimate but the authors have no means of assessing what the effect might be.

The formula used to compute the ${ }^{99} \mathrm{Tc}$ volatilization fraction $\left(f_{v}\right)$ was

$$
f_{v}=\frac{f_{\mathrm{o}} \cdot f_{\mathrm{Tc}}}{f_{c p} \cdot F_{s}}
$$

where $f_{\mathrm{o}}$ is the measured Re volatilization fraction from the LS-02 test, $f_{\mathrm{Tc}}$ is the volatilization ratio of $\mathrm{Tc} / \mathrm{Re}, f_{c p}$ is the average fraction of connected porosity, and $F_{s}$ is the cumulative average volume fraction of the sample pores where Re is swept out by diffusion. Derivation of each of these factors is discussed next.

\subsubsection{Re Volatilization Fraction}

Pieces of froth layer were removed by hand from approximately $1 / 2$ of the LS- 2 block, around the west-end electrode. The pieces were piled into two 55-gal drums and weighed. Water was then added and filled to the top of each drum. The glass scoria samples removed from the top of block were still quite hot; the interior temperature of the $\mathrm{BV}$ block was just below $500^{\circ} \mathrm{C}$ when the samples were taken. As a result, there was considerable boiling and spitting while water was added. The hottest glass samples likely shattered or cracked but the extent of any cracking was not quantified. The waterfilled drums were then sealed and weighed again. The drums were allowed to remain outdoors over a period of about 68 hours. Air temperatures during the day at this time reached $38^{\circ} \mathrm{C}$.

The drums were rolled to mix the leachate and then weighed again before opening. Approximately $25 \mathrm{~mL}$ of solution was removed, which was filtered to remove and fine particles, and then analyzed for Re content. From the known mass of glass in the drums, amount of water added, and mass of Re added to the $\mathrm{BV}$ box, the fraction of Re volatilized was calculated at $f_{\mathrm{o}}=0.017$.

\subsubsection{2 ${ }^{99} \mathrm{Tc} / \mathrm{Re}$ Volatilization Ratio}

Prior studies of high-temperature vitrification processes clearly show that Tc is significantly less volatile than Re (DARAB and SMITH, 1996). Fortunately, Kim et al. (2003) included both Re and Tc in an engineering-scale test of the BV process and following a procedure similar to what was described in Section 2.1.2.1, they determined that $f_{\mathrm{Tc}}=0.06$. We assume here that this same ratio applies at fullscale for the BV process and so used this value directly in our analysis. 


\subsubsection{Swept Volume Fraction}

Water will flood the connected porosity in the BV samples that were immersed in water in the 55gal drums. Although any water soluble Re salt present would immediately dissolve into the pore water, the dissolved Re must still be transported back to the sample surface to be mixed with the bulk water in the drum. Consequently, a correction factor was derived for the fraction of the scoria sample volume where Re would have been removed and counted in the bulk water samples.

The mean penetration depth $\left(d_{p}\right)$ from which solubilized Re would be removed is given by

$$
d_{p}=2 \sqrt{\phi D_{w} t_{s}}
$$

where and $\phi$ is the average fraction of connected porosity in the samples, $D_{w}$ is the free diffusion coefficient of water $\left(10^{-5} \mathrm{~cm}^{2} / \mathrm{s}\right)$, and $t_{s}$ is soak time. The fraction of connected porosity in the BKV5 sample was determined by Archimedes method and the value was surprisingly high, $f_{c p}=79 \%$. Lacking any other data as a guide, the connected porosity was then given by $\phi=\varepsilon f_{c p}=0.32 \times 0.79=0.25$. Setting $t_{s}=68 \mathrm{hrs}$ in Equation (6), the mean penetration depth is $d_{p}=1.6 \mathrm{~cm}$.

The swept volume fraction $\left(f_{s}\right)$ of a spherical sample of radius $r$ that would contribute Re to a wellmixed water bath surrounding the sample is given by

$$
f_{s}(r)=\frac{V_{d_{p}}}{V_{r}}=\frac{\frac{4}{3} \pi r^{3}-\frac{4}{3} \pi\left(r-d_{p}\right)^{3}}{\frac{4}{3} \pi r^{3}}=1-\frac{\left(r-d_{p}\right)^{3}}{r^{3}}
$$

The size distribution of the scoria pieces retrieved from the top western half of the LS-02 block was assumed to follow a logistic distribution of the form:

$$
p_{d}(r)=\frac{\exp \left(-\frac{\left(r-d_{p}\right)-r_{\mathrm{o}}}{s}\right)}{\left[1+\exp \left(-\frac{\left(r-d_{p}\right)-r_{\mathrm{o}}}{s}\right)\right]^{2} s}, r \geq d_{p}
$$

where $p_{d}$ is the probability distribution function, $r$ is the scoria sample radius, $r_{\mathrm{o}}$ is the mean radius, and $s$ is the scale parameter. Direct measurement of the diameters of the scoria pieces placed in the drums for water extraction was not performed. A mean diameter of $10 \mathrm{~cm}$ was assumed based on visual observation of the samples that were placed in the drums. A scale factor $(s)$ of 2 was assumed, which causes relatively large tails of the distribution and skews the distribution to weight the smaller size fraction. 
The total swept volume fraction for the particle size distribution given by Equation (8) is then given by

$$
F_{s}=\int_{d_{p}}^{\infty} f_{s}(r) p_{d}(r) d r
$$

Setting $d_{p}=1.6 \mathrm{~cm}, s=2 \mathrm{~cm}$, Equation (9) was numerically integrated with Mathematica ${ }^{\mathrm{TM}} \mathrm{V} 4.1$ and the value of $F_{s}$ was found to be 0.51 . So, we estimate that approximately $50 \%$ of the total soluble $\operatorname{Re}$ salt would have been extracted from the foam layer pieces.

Having now determined all the unknown values in Equation (5), we can compute the fraction of Tc volatilized:

$$
f_{v}=\frac{f_{\mathrm{o}} \cdot f_{\mathrm{Tc}}}{f_{c p} \cdot F_{s}}=\frac{0.017 \times 0.06}{0.79 \times 0.51}=0.3 \%
$$

An important caveat on the above analysis is that no attempts were made to include sand from the top or sides of the LS- 2 box in the drums. Sand at the top had been removed or fallen off before the scoria samples were obtained. Consequently, this estimate neglects any additional Re that might have condensed on the surfaces of these sand particles.

\subsubsection{Fused-Sand Layer}

Samples were removed as a function of depth from the glass interface from the broken edge piece shown in Figure 4. X-ray diffraction analysis of these samples is shown in Figure 8. Peaks associated with $\alpha$-tridymite and $\alpha$-cristobalite disappear in samples further away from the glass melt as expected.

The x-ray diffraction data were subjected to quantitative analysis and the resulting mass $\%$ of each phase are plotted versus depth from the glass interface in Figure 9.

\subsection{Single-Pass Flow-Through Testing}

Three sources of samples of BV glass were used for testing: 1) crucible melted, 2) engineering-scale test \#1 (EST-01), and 3) large-scale test \#2 (LST-02). The majority of the testing was performed on a crucible melt glass designated ASCM-01 that was heated treated to mimic centerline cooling of a large-scale melt (half-filled waste package). The crucible melt sample was selected

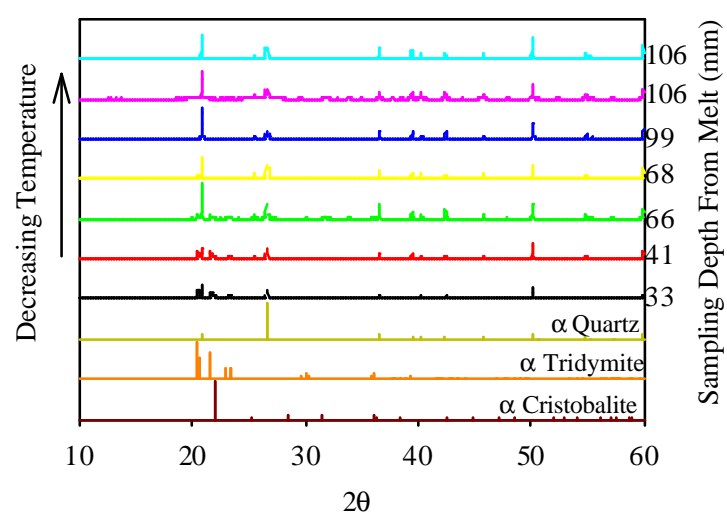

Figure 8. X-ray Diffraction Pattern of $\mathrm{SiO}_{2}$ Polymorphs as a Function of Depth and Relative Intensity

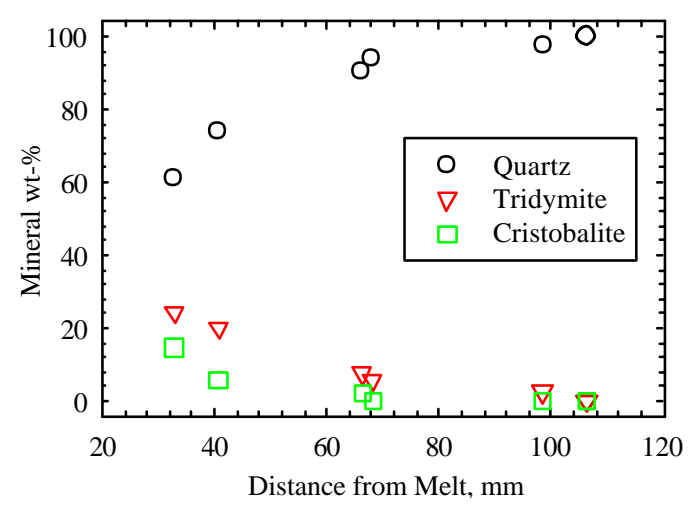

Figure 9. Quantitative X-ray Diffraction Data of $\mathrm{SiO}_{2}$ Polymorphs as a Function of Depth From Glass Melt Interface 
because it was immediately available and represented the target glass composition for the BV process (KIM et al., 2003). Glass from EST-01 was significantly impacted by dissolution of the quartz insulating layer used to line the container; the glass had significantly higher $\mathrm{SiO}_{2}$ and lower $\mathrm{Na}_{2} \mathrm{O}$ content than the target glass (KIM et al., 2003) and so was considered to poorly represent the BV product from a waste form performance perspective. Samples from LST-02 were not available until early August of 2003, which was too late to conduct the necessary testing in time for calculations. The LST-02 samples also deviated somewhat from the target composition (see Section 2.2.1.1 for details) because of quartz dissolution in the melt. We begin the discussion with chemical and physical characterization of the glass samples followed by test methods and results.

\subsubsection{Materials and Methods}

The methods and materials section provides information on the characterization techniques, experimental setup, and test conditions that were used for the testing of bulk vitrified glass.

\subsubsection{Bulk Composition Analysis}

Three samples from an engineering scale test (EST-01), one crucible melt sample, and two samples from the second large-scale test (LST02) of the BV process were selected for testing. Note that for ease of discussion, the labels used in the SPFT experiments, listed in Table 1, will be used when referring to individual experiments and the PNNL I.D. will be used when referring to a group of experiments on one glass sample. Samples from

Table 2. Calculated Thermal Cool down Profile for the Crucible Melt Sample and a AMEC Large Scale Bulk Vitrified Block

\begin{tabular}{c|c|c|c|c|c}
\hline Time (hr) & $\begin{array}{c}\text { Crucible Melt } \\
\text { C.D.S. }\left({ }^{\circ} \mathbf{C}\right)\end{array}$ & $\begin{array}{c}\text { dT/dt } \\
\left({ }^{\circ} \mathbf{C} / \mathrm{hr}\right)\end{array}$ & Time $(\mathbf{h r})$ & $\begin{array}{c}\text { Amec block } \\
\text { C.D.S. }\left({ }^{\circ} \mathbf{C}\right)\end{array}$ & $\begin{array}{c}\mathrm{dT} / \mathrm{dt} \\
\left({ }^{\circ} \mathbf{C} / \mathrm{hr}\right)\end{array}$ \\
\hline $0-14$ & $1300-1080$ & -15.71 & $0-6$ & $1600-1400$ & -33.33 \\
$14-38$ & $1080-880$ & -8.33 & $6-10$ & $1400-1300$ & -25.00 \\
$38-62$ & 880 to 720 & -6.67 & $10-24$ & $1300-1080$ & -15.71 \\
$62-86$ & $720-600$ & -5.00 & $24-48$ & $1080-880$ & -8.33 \\
$86-110$ & $600-500$ & -4.17 & $48-72$ & $880-720$ & -6.67 \\
& & & $72-96$ & $720-600$ & -5.00 \\
& & & $96-120$ & $600-500$ & -4.17 \\
\hline
\end{tabular}

C.D.S. = Cool down schedule

EST-01 were taken from the middle, in proximity to one of the electrodes, and top of the melt. Similarly, representative samples from LST-02 were taken from the middle and top of the melt. A crucible melt sample that had been heat-treated according to the expected centerline cooling curve (CCC), shown in Table 2, was also tested.

The average composition of each bulk vitrified glass formulation are displayed in Table 3, with a LAW glass formulation, LAWA44 shown for comparison. Detailed results from each analytical tech- 
nique are provided in Appendix A. The BV glass formulations are quite similar to LAWA44 glass, except for significantly less boron and much higher $\mathrm{ZrO}_{2}$ content. Also, samples from the EST-01 melt are approximately $25 \%$ lower in $\mathrm{Na}_{2} \mathrm{O}$ content than the target composition expected in a full scale $\mathrm{BV}$ melt. The composition of each glass sample was identified using a combination of energy-dispersive and wavelength $\mathrm{x}$-ray fluorescence, as well as, determining the analytical chemistry of sodium peroxide $\left(\mathrm{Na}_{2} \mathrm{O}_{2}\right)$ and lithium borate $\left(\mathrm{LiBO}_{2}\right)$ fusions via inductively coupled optical emission mass spectrometry (ICP-OES) and/or inductively coupled mass spectroscopy (ICP-MS). For a more detail description of the techniques used and interested reader should refer to (MCGRAIL et al., 2000).

Table 3. *Normalized Chemical Composition of Bulk Vitrified Glass Samples with WTP Glass Sample LAWA44 for Comparison

\begin{tabular}{ccccccccc}
\hline Oxide & Target & BKV1 & BKV2 & BKV3 & BKVX & BKV4 & BKV5 & LAWA44 \\
\hline $\mathrm{Al}_{2} \mathrm{O}_{3}$ & 9.890 & 8.692 & 7.872 & 8.568 & 6.94 & 8.13 & 9.26 & 6.2 \\
$\mathrm{~B}_{2} \mathrm{O}_{3}$ & 5.000 & 5.987 & 5.651 & 5.489 & 4.87 & 5.89 & 6.10 & 8.9 \\
$\mathrm{CaO}$ & 3.750 & 2.707 & 3.375 & 2.828 & 2.66 & 2.68 & 3.21 & 1.99 \\
$\mathrm{Cl}$ & 0.180 & 0.033 & 0.072 & 0.041 & 0.03 & 0.03 & 0.05 & 0.65 \\
$\mathrm{Cr}_{2} \mathrm{O}_{3}$ & 0.090 & 0.090 & 0.057 & 0.028 & 0.05 & 0.05 & 0.05 & 0.02 \\
$\mathrm{Fe}_{2} \mathrm{O}_{3}$ & 6.330 & 3.688 & 2.826 & 3.493 & 2.57 & 4.43 & 5.23 & 6.98 \\
$\mathrm{~K}_{2} \mathrm{O}$ & 1.760 & 1.653 & 2.235 & 2.156 & 1.73 & 1.96 & 2.22 & 0.5 \\
$\mathrm{MgO}$ & 0.970 & 1.232 & 1.390 & 1.123 & 0.98 & 1.25 & 1.41 & 1.99 \\
$\mathrm{Na}_{2} \mathrm{O}$ & 20.00 & 22.19 & 23.96 & 23.45 & 19.74 & 14.78 & 16.30 & 20 \\
$\mathrm{P}_{2} \mathrm{O}_{5}$ & 0.600 & 0.417 & 0.203 & 0.210 & 0.19 & 0.26 & 0.27 & 0.03 \\
$\mathrm{ReO}_{2}$ & 0.0100 & 0.0012 & 0.0018 & $\mathrm{BLQ}$ & 0.00 & 0.00 & $\mathrm{BLQ}$ & $\mathrm{BLQ}$ \\
$\mathrm{SO}_{3}$ & 0.830 & 0.669 & 0.497 & 0.429 & 0.09 & 0.47 & 1.40 & 0.1 \\
$\mathrm{SiO}_{2}$ & 42.55 & 45.20 & 46.39 & 45.88 & 55.46 & 53.93 & 47.32 & 44.55 \\
$\mathrm{TiO}_{2}$ & 0.970 & 0.630 & 0.545 & 0.612 & 0.47 & 0.74 & 0.84 & 1.99 \\
$\mathrm{ZrO}_{2}$ & 7.000 & 6.815 & 4.924 & 5.686 & 4.22 & 5.39 & 6.34 & 2.99 \\
\hline $\mathrm{Total}^{9}$ & 99.9 & 100.0 & 100.0 & 100.0 & 100.0 & 100.0 & 100.0 & 96.9 \\
\hline $\mathrm{BLQ}$ Below Limit of Quantification & & & & & \\
\hline
\end{tabular}

${ }^{\mathrm{a}}$ Composition used in the computation of the rate law parameters. This initial composition was determined using a combination of XRF and analytical chemistry analysis of fusions via ICP-OES for Al, B, Na, and Si; the remaining elements were determined using the results of XRF analyses.

${ }^{b}$ Revised composition was determined using a combination of XRF and analytical chemistry analysis of fusions via ICP-OES or ICP-MS.

${ }^{\mathrm{c}}$ Four significant figures are shown to accurately capture the low concentration of $\mathrm{ReO} 2$ in the sample. Mass percents of oxides with concentrations above $0.001 \%$ should not be considered accurate to five significant figures.

\subsubsection{Sample Preparation}

The samples used in this study were prepared by crushing glass in a ceramic ball mill. The crushed glass was then sieved into $-100+200$ mesh $(150$ to $75 \mu \mathrm{m})$ size fractions, washed in deionized water (DIW), sonicated in DIW, rinsed in ethanol, and dried in a $90^{\circ} \mathrm{C}$ oven. The specific surface area of each sample was calculated using a geometric formula (MCGRAIL et al., 1997). This formula assumes that the particles are spherical, size distributions of the grains are normally distributed, and that surface pits, cracks, and other forms of surface roughness do not affect the surface area. Although all three of these assumptions may not be valid, results from LAW glass experiments using glass coupons, with a 
calculated and measured surface area, have shown that the geometric surface area best represents the overall glass surface area (MCGRAIL et al., 2000).

\subsubsection{Buffer Solutions}

The solutions used to control the $\mathrm{pH}$ during the SPFT experiments are summarized in Table 4. Table 4 also contains a summary of the in-situ $\mathrm{pH}$ values computed at each test temperature using EQ3NR (WOLERY, 1992a). It is important to take into account the change in pH that occurs at different temperatures when computing dissolution rates from SPFT data as the in-situ pH can vary by as much as $1.5 \mathrm{pH}$ units over the temperature range from $23^{\circ}$ to $90^{\circ} \mathrm{C}$. These solutions were prepared by adding small amounts of the organic THAM buffer to DIW and adjusting the solution to the desired $\mathrm{pH}$ value using $15.8 \mathrm{M} \mathrm{HNO}_{3}$ or $1 \mathrm{M} \mathrm{LiOH}$. The THAM buffer range is between $\mathrm{pH} 7$ to 10 ; therefore the alkaline solutions, $\mathrm{pH}$ range 11 and 12, were prepared by adding of $\mathrm{LiOH}$ and $\mathrm{LiCl}$ to DIW and adjusting the solution to the desired $\mathrm{pH}$ value using $15.8 \mathrm{M} \mathrm{HNO}_{3}$ or $1 \mathrm{M} \mathrm{LiOH}$.

Silicon concentration was varied from saturated to dilute for select experiments. These solutions were prepared by dissolving analytical grade silicic acid powder $\left(\mathrm{SiO}_{2} \cdot \mathrm{H}_{2} \mathrm{O}\right)$ in a solution of $0.05 \mathrm{M}$ Tris buffer and heating the mixture in a $90^{\circ} \mathrm{C}$ oven for no less than three days to facilitate complete dissolution. Upon complete dissolution each solution was removed from the oven, allowed to cool, and $\mathrm{pH}$ adjusted (target $\mathrm{pH}=9$ ) using aliquots of $15.8 \mathrm{M} \mathrm{HNO}_{3}$ or $1 \mathrm{M} \mathrm{LiOH}$. The amount of $\mathrm{Si}$ added was altered from dilute to saturation with respect to amorphous silica $\left[\mathrm{SiO}_{2}(\mathrm{am})\right]$, based on the results from calculations using EQ3NR (WOLERY, 1992a). It is important to note that the solubility behavior of $\mathrm{SiO}_{2}$ (am) changes with temperature, therefore, the target amount of $\mathrm{Si}$ added to each solution was adjusted to correspond to the experimental temperature being interrogated, resulting in Si solution concentrations that ranged from 15 to $140 \mathrm{ppm}$.

\subsubsection{SPFT Apparatus}

Dissolution experiments were conducted using the single pass flow-through (SPFT) apparatus (Figure 10). The SPFT experimental system provides a continuous flow of fresh input solution, prevents

Table 4. Composition of Solutions Used in SPFT Experiments. Solution pH values above $23^{\circ} \mathrm{C}$ were calculated with EQ3NR Code V7.2b database.

\begin{tabular}{|c|c|c|c|c|c|}
\hline \multirow[t]{2}{*}{ Solution } & \multirow[t]{2}{*}{ Composition } & \multicolumn{4}{|c|}{ pH @ } \\
\hline & & $23^{\circ} \mathrm{C}$ & $40^{\circ} \mathrm{C}$ & $70^{\circ} \mathrm{C}$ & $90^{\circ} \mathrm{C}$ \\
\hline 1 & $0.05 \mathrm{M}$ Tris $+0.047 \mathrm{M} \mathrm{HNO}_{3}$ & 7.01 & 6.57 & 5.91 & 5.55 \\
\hline 2 & $0.05 \mathrm{M}$ Tris $+0.02 \mathrm{M} \mathrm{HNO}_{3}$ & 8.32 & 7.90 & 7.25 & 6.89 \\
\hline 3 & $0.05 \mathrm{M}$ Tris $+0.0041 \mathrm{M} \mathrm{HNO}_{3}$ & 8.99 & 8.67 & 8.08 & 7.72 \\
\hline 4 & $0.05 \mathrm{M}$ Tris $+0.003 \mathrm{M} \mathrm{LiOH}$ & 9.99 & 9.55 & 8.88 & 8.52 \\
\hline 5 & $0.0107 \mathrm{M} \mathrm{LiOH}+0.010 \mathrm{M} \mathrm{LiCl}$ & 11.00 & 10.89 & 10.43 & 10.06 \\
\hline 6 & $0.0207 \mathrm{M} \mathrm{LiOH}+0.010 \mathrm{M} \mathrm{LiCl}$ & 12.02 & 11.74 & 11.08 & 10.70 \\
\hline 7 & $0.05 \mathrm{M}$ Tris $+\mathrm{Si}^{*}$ & 9.00 & 8.83 & 8.51 & 8.27 \\
\hline
\end{tabular}

Tris $=$ Tris hydroxymethyl aminomethane (THAM) buffer 
the buildup of reaction products, maintains the bulk solution composition throughout an experiment, provides a direct measure of the dissolution rate, and allows an investigator to study the reactivity of a material over a wide range of experimental conditions. This system has been extensively described by others (HOLDREN and SPEYER, 1987); (CHOU and Wollast, 1984); (CARROLL and BRUNO, 1991); and (MCGRAIL et al., 2000), and an interested reader should consult these references, as well as the references contained therein for more detail.

In general, solution is transferred using a Kloehn syringe pump (Model 50300) from a reservoir bottle to a Teflon re-

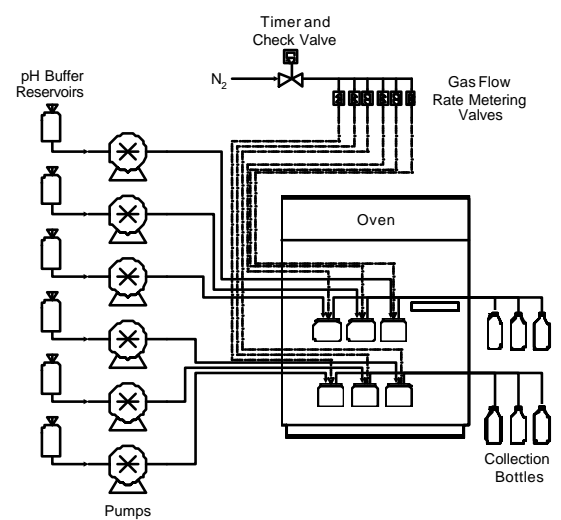

Figure 10. Schematic of the Single Pass Flow-Through (SPFT) Apparatus actor and finally to a sample collection vial via $1 / 16^{\text {th }}$ inch Teflon tubing. The Teflon reactor vessels consisted of two main pieces, (e.g., a top and bottom) that threaded together to form a cylinder with a 1.87-inch outer diameter and 2.48-inch height, with a total inner volume of approximately $80 \mathrm{~mL}$. The relatively large diameter of the sample holder (1.60-inch inner diameter) allows the glass particles to form a thin layer at the reactor bottom and interact with the contacting solution. Once collected, the effluent solutions were monitored for 4 main glass components, aluminum $(\mathrm{Al})$, boron $(\mathrm{B})$, sodium $(\mathrm{Na})$, and silicon $(\mathrm{Si})$ using ICP-OES.

\subsubsection{Dissolution Rate and Error Calculations}

Dissolution rates, based on steady-state concentrations of elements in the effluent, are normalized to the amount of the element present in the sample by the following formula:

$$
\text { Normalized dissolution rate }\left(\mathrm{g} \mathrm{m}^{-2} \mathrm{~d}^{-1}\right)=\frac{\left(C_{i}-\bar{C}_{i, b}\right) q}{f_{i} S}
$$

where $C_{i}$ is the concentration of the element, $i$, in the effluent $\left(\mathrm{g} \mathrm{L}^{-1}\right), \bar{C}_{i, b}$ is the average background concentration of the element of interest $\left(\mathrm{g} \mathrm{L}^{-1}\right), q$ is the flow-through rate $\left(\mathrm{L} \mathrm{d}^{-1}\right), f_{i}$ is the mass fraction of the element in glass (dimensionless), and $S$ is the surface area of the sample $\left(\mathrm{m}^{2}\right)$. The value of $f_{i}$ can be calculated from the chemical composition of the sample. Flow-through rates are determined by gravimetric analysis of the fluid collected in each effluent collection vessel upon sampling. The background concentration of the element of interest is determined, as previously discussed, by analyses of the starting input solution and the three blank solutions. Typically, background concentrations of elements are below their respective detection threshold. The detection threshold of any element is defined here as the lowest calibration standard that can be determined reproducibly during an analytical run within $10 \%$. In cases where the analyte is below the detection threshold, the background concentration of the element is set at the value of the detection threshold.

Determining the experimental uncertainty of the dissolution rate takes into account uncertainties of each parameter in Equation (11). For uncorrelated random errors, the standard deviation of a function $f\left(x_{1}, x_{2}, \ldots x_{n}\right)$ is given by: 


$$
\sigma_{f}=\sqrt{\sum_{i=1}^{n}\left(\frac{\partial f}{\partial x_{i}}\right)^{2} \sigma_{i}^{2}}
$$

where

$$
\begin{aligned}
& \sigma_{f}=\text { standard deviation of the function } f . \\
& x_{i}=\text { parameter } i \\
& \sigma_{i}=\text { standard deviation of parameter } i .
\end{aligned}
$$

Substituting (11) into (12) results in:

$$
\sigma_{r_{i}}=\sqrt{\left(\frac{q}{f_{i} S}\right)^{2}\left(\sigma_{C_{i}}^{2}+\sigma_{\bar{C}_{i, b}}^{2}\right)+\left(\frac{C_{i}-\bar{C}_{i, b}}{f_{i} S}\right)^{2} \sigma_{q}^{2}+\left(\frac{\left(C_{i}-\bar{C}_{i, b}\right) q}{f_{i}^{2} S}\right)^{2} \sigma_{f_{i}}^{2}+\left(\frac{\left(C_{i}-\bar{C}_{i, b}\right) q}{f_{i} S^{2}}\right)^{2} \sigma_{S}^{2}}
$$

Equation (13) can also be expressed in terms of the relative error, $\hat{\sigma}_{r_{i}}=\sigma_{r_{i}} / r_{i}$, and is given by

$$
\hat{\sigma}_{r_{i}}=\sqrt{\frac{\left(\hat{\sigma}_{C_{i}} C_{i}\right)^{2}+\left(\hat{\sigma}_{\bar{C}_{i, b}} \bar{C}_{i, b}\right)^{2}}{\left(C_{i}-\bar{C}_{i, b}\right)^{2}}+\hat{\sigma}_{q}^{2}+\hat{\sigma}_{f_{i}}^{2}+\hat{\sigma}_{S}^{2}}
$$

Relative errors of $10 \%, 10 \%, 5 \%, 3 \%$, and $15 \%$ for $C_{i}, \bar{C}_{i, b}, q, f_{i}$, and $S$, respectively, are typical for measurements conducted at PNNL. Although the absolute error in $f_{i}$ is likely significantly higher than $3 \%$, this error is non-systematic and so does not contribute significantly to sample-to-sample uncertainty, which is the principal error of interest here. The conservative appraisal of errors assigned to the parameters in Equation (14), in addition to the practice of imputing detection threshold values to background concentrations, results in typical uncertainties of approximately $\pm 35 \%$ on the dissolution rate.

\subsubsection{SPFT Results}

Silicate waste glass dissolution depends strongly on temperature, $\mathrm{pH}$, and the solution chemistry contacting the glass (MCGRAIL et al., 2000). As expected, dissolution of bulk vitrified glass followed very similar patterns as has been observed for WTP glasses. A comprehensive list of the experimental conditions, including temperature, solution $\mathrm{pH}$, flow-through rates $(q)$, and solution saturation state used in these experiments is given in Appendix B. The majority of the reported rates are based on the boron concentration. Boron was chosen as the primary element for the determination of the rate law constants because it is a major glass matrix component and does not exhibit solubility effects under the experimental conditions examined. Therefore, the boron release rate represents the overall dissolution of the glass matrix. 
To simplify the discussion, the data set has been divided into two sections. The first section will discuss the results of tests conducted using crucible melt samples to determine rate law parameters for bulk vitrified glass dissolution. This section will be followed by a second section that will compare the experimental results obtained from three EST-01 and two LST-02 samples to the data used to determine the rate law parameters for the STORM code.

\subsubsection{Crucible Melt BV Glass BKV1 (ASCM-01)}

\subsection{Effect of $\mathrm{pH}$}

To determine the effect of $\mathrm{pH}$ on the dissolution rate, solution $\mathrm{pH}$ values were varied between 7 and 12 at temperatures of $23,40,70$, and $90^{\circ} \mathrm{C}$. The in situ solution $\mathrm{pH}$ has been corrected for the effect of temperature using EQ3NR (see Table 4). Figure 11 illustrates that as the $\mathrm{pH}$ increases from 7 to 12 , the overall glass dissolution rate also increases. This direct relationship between the dissolution rate and $\mathrm{pH}$, going from the neutral to alkaline $\mathrm{pH}$ range, is typical of other LAW glass formulations (MCGRAIL et al., 2001a). Conducting a linear regression on the data at each temperature gave a slope $\eta=0.42$ \pm 0.02 indicating that $\eta$ does not depend on temperature within experimental error. Using this value for $\eta$, a non-linear regression was performed on the entire data set shown in Figure 11 using the kinetic rate law (MCGRAIL et al., 2003a)

$$
J=k_{\mathrm{o}} 10^{\eta[\mathrm{pH}]} \exp \left(\frac{-E_{a}}{\mathrm{R} T}\right)
$$

where $J$ is the normalized release rate, $k_{\mathrm{o}}$ is the intrinsic rate constant, $\eta$ is the $\mathrm{pH}$ power law coefficient, $E_{a}$ is the activation energy, $\mathrm{R}$ is the ideal gas constant, and $T$ is the temperature. The resulting regression coefficients are $k_{\mathrm{o}}=1.5 \pm 1.43 \mathrm{~mol} \mathrm{~m}^{-2} \mathrm{~s}^{-1}, E_{a}=77 \pm 3 \mathrm{~kJ} \mathrm{~mol}^{-1}$ with a correlation coefficient $\left(\mathrm{R}^{2}\right)$ of 0.96. ${ }^{\mathrm{a}}$ The value of $k_{\mathrm{o}}, E_{a}$, and $\eta$ are within the experimental error of values reported for LAW glass formulation LD6-5412 (MCGRAIL et al., 1997), $\left(k_{\mathrm{o}}=1.75 \mathrm{~mol} \mathrm{~m}^{-2} \mathrm{~s}^{-1}, E_{a}=75 \pm 1 \mathrm{~kJ} \mathrm{~mol}^{-1}\right.$, and $\eta=0.40 \pm 0.03)$

Figure 11 also illustrates that temperature has a strong effect on the dissolution rates. The apparent activation energy determined ( $E_{a}=76 \pm 3 \mathrm{~kJ}$ mol-1) corresponds to a surface controlled reaction process, 41.8 to $83.7 \mathrm{~kJ}$ mol-1 (Lasaga, 1981). This value is in good agreement with the values reported

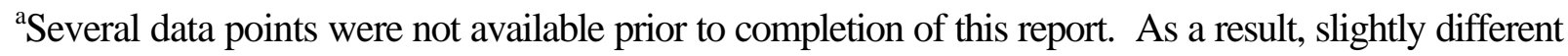
regression coefficients were calculated and used for STORM simulations (Mann et al. 2003). These were: $k_{\mathrm{o}}=1.80 \mathrm{~mol} \mathrm{~m} \mathrm{~s}^{-1}, E_{a}=73.3 \mathrm{~kJ} / \mathrm{mol}$, and $\eta=0.37$. 
for other LAW glass formulations and several $\mathrm{SiO}_{2}$ polymorphs [LAWABP1 $=68 \mathrm{~kJ} / \mathrm{mol}$ (McGrail et al 2000), quartz $=66-83 \mathrm{~kJ} \mathrm{~mol}^{-1}$ (Dove, 1994), $\mathrm{SiO}_{2}(\mathrm{am})=74.5 \mathrm{~kJ} / \mathrm{mol}$ (Icenhower and Dove, 2000), and cristobalite $=69 \mathrm{~kJ} / \mathrm{mol}$ (Renders, 1995)], suggesting that the rupture of the $\mathrm{SiO}$ bond is the rate-limiting step in dissolution.

Another factor affecting glass dissolution that is observed when evaluating the dissolution rate as a function of $\mathrm{pH}$ and temperature is ion exchange. Ion exchange is a process by which $\mathrm{H}^{+}$, contained in the solution, exchanges for the ions contained in the glass matrix, as illustrated by

$$
\text { Glass } \cdots \mathrm{Na}+\mathrm{H}^{+} \stackrel{J_{x}}{\longrightarrow} \text { Glass } \cdots \mathrm{H}+\mathrm{Na}^{+} \text {. }
$$

The addition of this mechanism may affect BV glass performance because of the significant $\mathrm{Na}_{2} \mathrm{O}$ content. Methods to quantify the Na ion-exchange rate for the BKV1 glass are discussed below.

\subsection{Effect of Ion Exchange}

The rate of ion exchange (IEX) was computed by subtracting the rate of matrix dissolution from the Na release rate and converting the resulting value to moles of $\mathrm{Na}$ per square meter per second. Figure 12 shows the computed ion exchange rate from temperatures of 23 to $90^{\circ} \mathrm{C}$. These results illustrate a very shallow decrease in ion-exchange rate with increasing $\mathrm{pH}$. Conducting a linear regression on the data at each temperature gave a slope $\eta=-0.051 \pm 0.004$, indicating that $\eta$ probably does not depend on temperature but this will require confirmation from additional experiments. Using the value of $\eta$ above, a non-linear regression was performed on the entire data set shown in Figure 12 using the kinetic rate law, Equation (15), and modifying it to Equation (17)

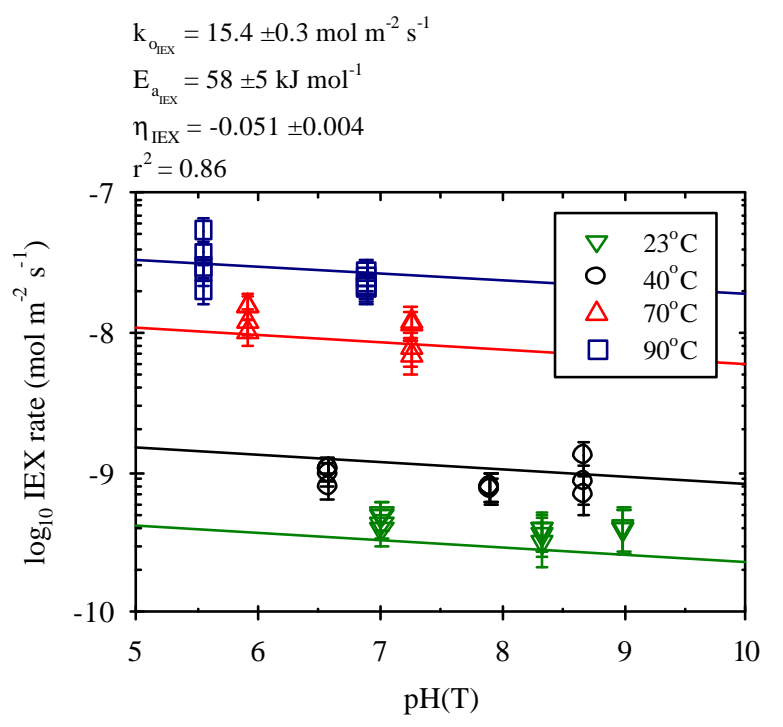

Figure 12: Na Ion Exchange Rate as a Function of Solution $\mathrm{pH}$ and Temperature.

$$
J_{x}=k_{x} 10^{\eta_{x}[\mathrm{pH}]} \exp \left(\frac{-E_{x}}{\mathrm{RT}}\right)
$$

where $J_{x}$ is the Na ion exchange rate, $k_{x}$ is the intrinsic exchange rate constant, $\eta_{x}$ is the IEX power law coefficient, $E_{x}$ is the activation energy. The resulting regression coefficients, used in the STORM calculations, were $k_{x}=15.4 \pm 0.3 \mathrm{~mol}[\mathrm{Na}] \mathrm{m}^{-2} \mathrm{~s}^{-1}, E_{x}=58 \pm 5 \mathrm{~kJ} \mathrm{~mol}^{-1}$, and $\eta_{x}=-0.051 \pm 0.004$ with a correlation coefficient $\left(\mathrm{R}^{2}\right)$ of 0.86 .

The effect of IEX was also observed in experiments where the concentration of Si in the influent solution was varied. Figure 13 illustrates the natural logarithm of the IEX rate versus 1/T for each $\mathrm{SiO}_{2}(\mathrm{aq})$ activity interrogated. Conducting a linear regression on the data resulted in a $E_{x}=53 \pm 2 \mathrm{~kJ}$ 
$\mathrm{mol}^{-1}$. The resulting $E_{x}$ correlates well with the LAW glass formulation LAWABP1 $\left(E_{x}=52 \mathrm{~kJ} \mathrm{~mol}^{-1}\right)$ (MCGRAIL et al., 2001a).

\subsection{Effect of Solution Saturation State}

As previously discussed, experiments with input solutions doped with $\mathrm{Si}$ (ranging from 15 to $140 \mathrm{ppm}$ ) were conducted as a function temperature at $\mathrm{pH}\left(23^{\circ} \mathrm{C}\right)$ of 9 . Before discussing these results, it is important to determine the aqueous $\mathrm{Si}$ speciation at each temperature to correctly account for the change in Si speciation with temperature in the analysis. Therefore, the solution speciation of dissolved Si species was computed with the aid of the geochemical code EQ3NR (WOLERY, 1992a). Results of this computation shows that $\mathrm{SiO}_{2}(\mathrm{aq})$ was the dominant solution species in the buffer solution from 23 to $90^{\circ} \mathrm{C}$, ranging from $90 \%$, at $23^{\circ} \mathrm{C}$, to $87 \%$, at $90^{\circ} \mathrm{C}$.

The remaining 10 and $13 \%$, at 23 and $90^{\circ} \mathrm{C}$ re-

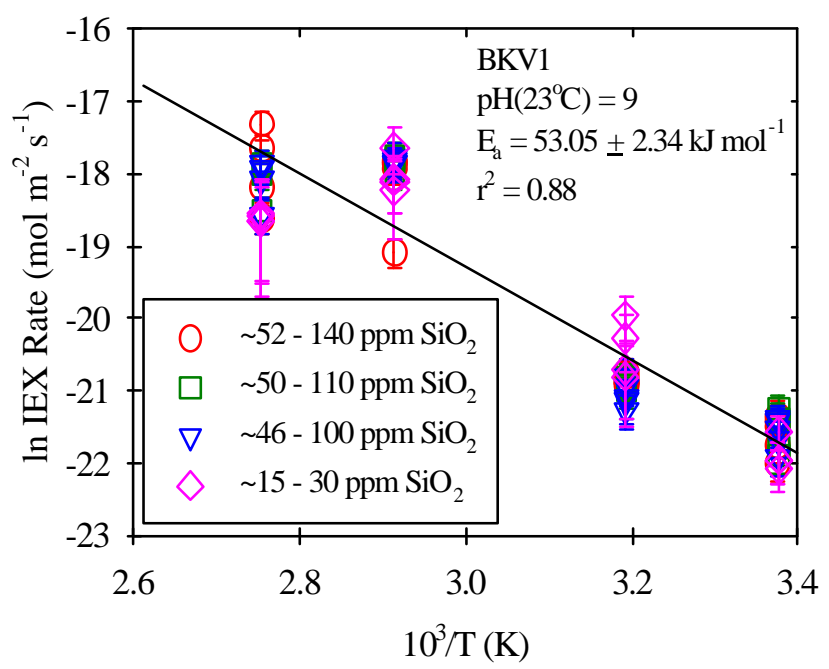

Figure 13. Na Ion Exchange Rate Versus Reciprocal Temperature for $\mathrm{SiO}_{2}(\mathrm{aq})$ activity ranging from 15 to $140 \mathrm{ppm}$ spectively, corresponds to the solution species $\mathrm{HSiO}_{3}{ }^{-}$.

Normalized release rates for $\mathrm{B}$ and $\mathrm{Na}$ as a function of $a\left[\mathrm{SiO}_{2}(\mathrm{aq})\right]$ are shown in Figure 14. The trend, a decrease in the dissolution rate with increasing $\mathrm{SiO}_{2}(\mathrm{aq})$ activity, is similar to those obtained for several LAW glass formulations (MCGRAIL et al., 2001a). As the activity $\mathrm{SiO}_{2}$ (aq) increases, Figure 14 also shows an increasing discrepancy between the bulk glass dissolution rate, as indicated by the rate of B release, versus the normalized rate of Na release. The discrepancy has been assigned to a secondary reaction mechanism associated with $\mathrm{Na}$ ion exchange. However, unlike other LAW glass formulations, such as LAWABP1, the release rate of $\mathrm{Na}$ and $\mathrm{B}$ does not converge completely at $90^{\circ} \mathrm{C}$. This is almost certainly due to the $10 \mathrm{X}$ higher Na IEX rate for the BKV1 glass as compared with LAWABP1; the $\mathrm{Na}$ IEX is still detectable at $90^{\circ} \mathrm{C}$ in Si-saturated solutions with the BKV1 glass but is overwhelmed by matrix dissolution at $90^{\circ} \mathrm{C}$ with LAWABP1 glass. The BKV1 glass should have a higher concentration of non-bridging oxygen (NBO) sites relative to LAWABP1 based on its composition. The NBO concentration has been directly correlated with $\mathrm{Na}$ ion-exchange rates in simple glasses (MCGRAIL et al., 2001b).

By applying a linear fit to the normalized $B$ release rates as they approached zero for the data shown in Figure 14, the $\mathrm{x}$-intercept was determined at each temperature, which is equivalent to the pseudo-equilibrium constant $\left(K_{g}\right)$. The estimated $K_{g}$ values are given in Table 5 and also plotted versus inverse temperature in Figure 15, along with the temperature-dependent solubility products for quartz and $\mathrm{SiO}_{2}(\mathrm{am})$. The results show the $\mathrm{K}_{\mathrm{g}}$ for $\mathrm{BKV} 1$ glass is intermediate between quartz and amorphous silica. The slope of a line regressed through the data also provides a crude estimate of the enthalpy of reaction, $\Delta \mathrm{H}_{\mathrm{r}}=12 \pm 2 \mathrm{~kJ} \mathrm{~mol}^{-1}$. Using the regression line shown in Figure 15, the value for $\mathrm{K}_{\mathrm{g}}$ at the disposal system temperature of $15^{\circ} \mathrm{C}$ was calculated and is provided in Table 5 . 

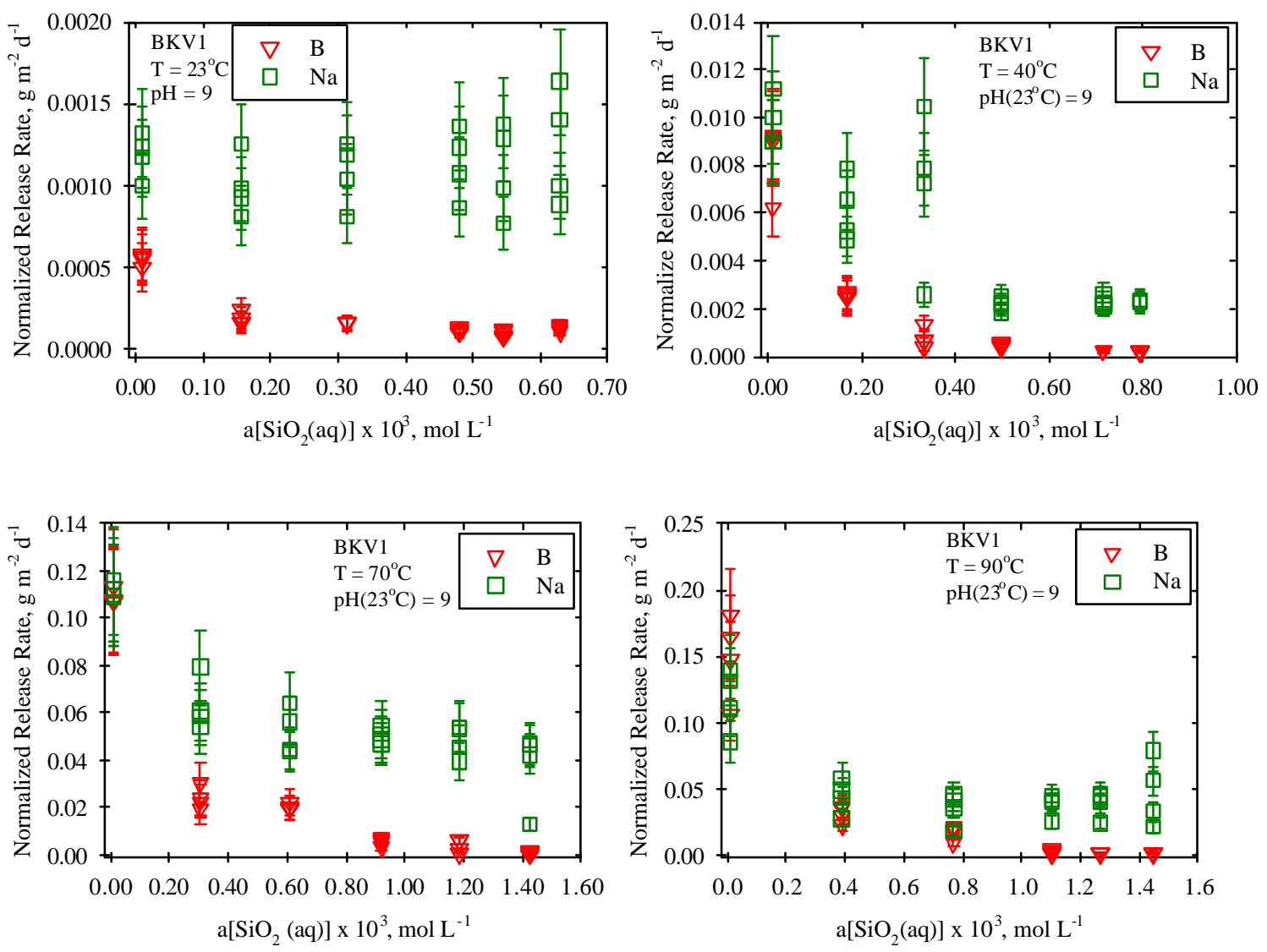

Figure 14. Normalized Release Rate with Respect to $\mathrm{B}$ and $\mathrm{Na}$ Versus $\mathrm{SiO}_{2}(\mathrm{aq})$ Activity at 23, 40,70 , and $90^{\circ} \mathrm{C}$.

Table 5. Estimate of the Pseudo-Equilibrium Constants for BKV1 as a Function of Temperature.

\begin{tabular}{c|c|c|c}
\hline $\mathbf{T}\left({ }^{\mathbf{0}} \mathbf{C}\right)$ & $\mathbf{K}_{\mathbf{g}}$ & Error & $\mathbf{R}^{\mathbf{2}}$ \\
\hline 15 & $3.23 \mathrm{E}-4$ & - & - \\
23 & $3.94 \mathrm{E}-4$ & $\pm 3.09 \mathrm{E}-4$ & 0.77 \\
40 & $4.48 \mathrm{E}-4$ & $\pm 2.91 \mathrm{E}-5$ & 0.76 \\
70 & $6.54 \mathrm{E}-4$ & $\pm 1.53 \mathrm{E}-5$ & 0.77 \\
90 & $9.65 \mathrm{E}-4$ & $\pm 2.65 \mathrm{E}-5$ & 0.74 \\
\hline
\end{tabular}

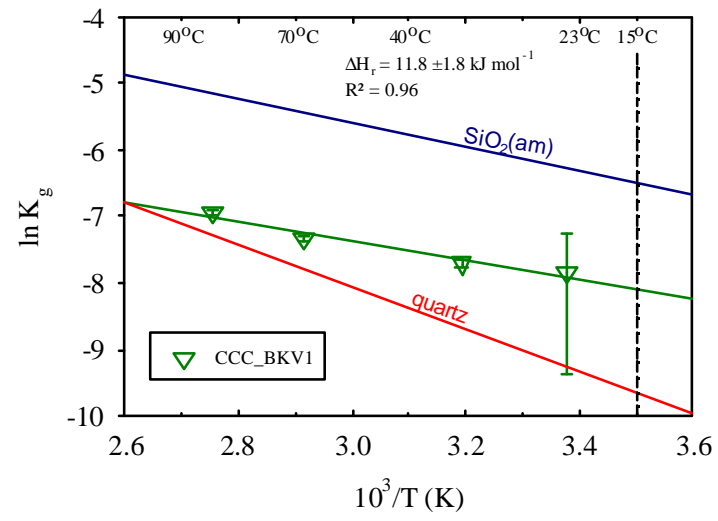

Figure 15. $\ln \mathrm{K}_{\mathrm{g}}$ vs. Inverse Temperature 


\subsubsection{Comparison of Rate Law Parameters to EST-01 and LST-02 BV Glass Samples}

As previously discussed, the crucible melt sample (BKV1) was used to quantify each of the kinetic rate law parameters needed to accurately model glass dissolution. A detailed explanation for selecting the crucible melt sample instead of the EST-01 and LST-02 samples has been provided in section 2.2. As a result of selecting the crucible melt sample to quantify the kinetic rate law parameters, the results of these experiments must be compared to actual glass samples created using the BV process. Therefore, select SPFT experiments were conducted using three EST-01 samples (BKVX, BKV2, and BKV3) and two LST-02 samples (BKV4 and BKV5). These test were conducted as a function of $\mathrm{pH}$ (from 7 to 12 ), solution saturation (from 0 to $140 \mathrm{ppm} \mathrm{Si}$ ), and temperature (from 23 to $90^{\circ} \mathrm{C}$ ).

Normalized release rates for $\mathrm{B}$ as a function of $\mathrm{pH}$ are shown in Figure 16. This figure illustrate that the results obtained at $\mathrm{pH}\left(23^{\circ} \mathrm{C}\right) 9$ using $\mathrm{BKVX}$ (T ranging from 23 to $90^{\circ} \mathrm{C}$ ), and $\mathrm{BKV} 2, \mathrm{BKV} 3$, $\mathrm{BKV} 4$, and BKV5 $\left(\mathrm{T}=90^{\circ} \mathrm{C}\right)$ are with in the experimental error of the values reported for BKV1. Additional experiments were conducted using the LST-02 glass sample BKV5 at $90^{\circ} \mathrm{C}$ as a function of $\mathrm{pH}$ (ranging from 7 to 12). Conducting a linear regression on these results provided a slope $\eta_{\text {вки }}=$ $0.38 \pm 0.03$ with a correlation coefficient $\left(\mathrm{R}^{2}\right)$ of 0.92 . The value of $\eta_{\text {вку }}$ is within the experimental error for BV glass sample BKV1 as well as other LAW glass formulations, LD6-5412 and LAWBP1, (refer to section 2.2.2.1.1).

Several experiments were also conducted using solutions doped with $\mathrm{Si}$ (ranging from 0 to 140 $\mathrm{ppm}$ ) as a function of temperature (from 23 to $90^{\circ} \mathrm{C}$ ) on BKVX and BKV4. By applying a linear fit to the normalized B release rates as they approached zero, a pseudo-equilibrium constant $\left(K_{g}\right)$ was determined for BKVX and BKV4. The estimated $K_{g}$ values are displayed in Table 6 and are plotted versus inverse temperature in Figure 17, along with the temperature dependent solubility products for quartz and $\mathrm{SiO}_{2}(\mathrm{am})$. The results show that the $K_{g}$ for BKVX and BKV4 are within the experimental error of $\mathrm{BKV} 1$, and lie between the temperature dependant solubility products for quartz and $\mathrm{SiO}_{2}(\mathrm{am})$. As previously discussed in section 2.2.2.1.3, regressing a line through the temperature-dependant $K_{g}$ values

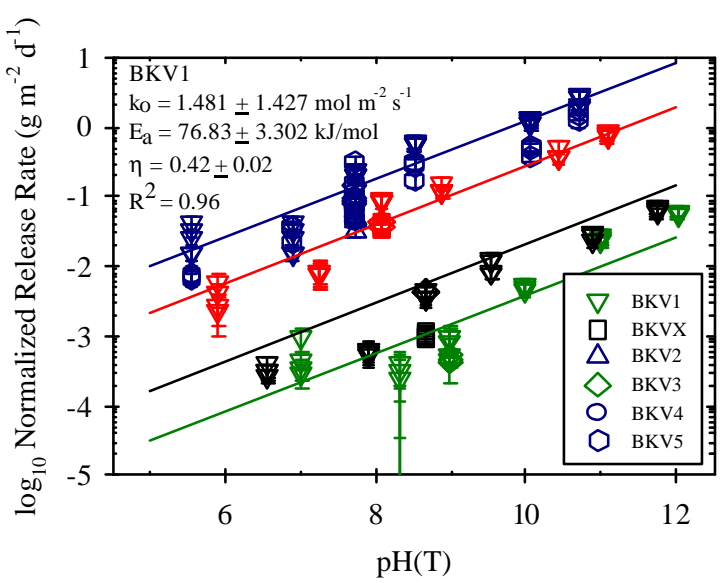

Figure 16: Comparison of Normalized B Release Rates as a Function of $\mathrm{pH}$ and Temperature for Each Glass Sample Tested.

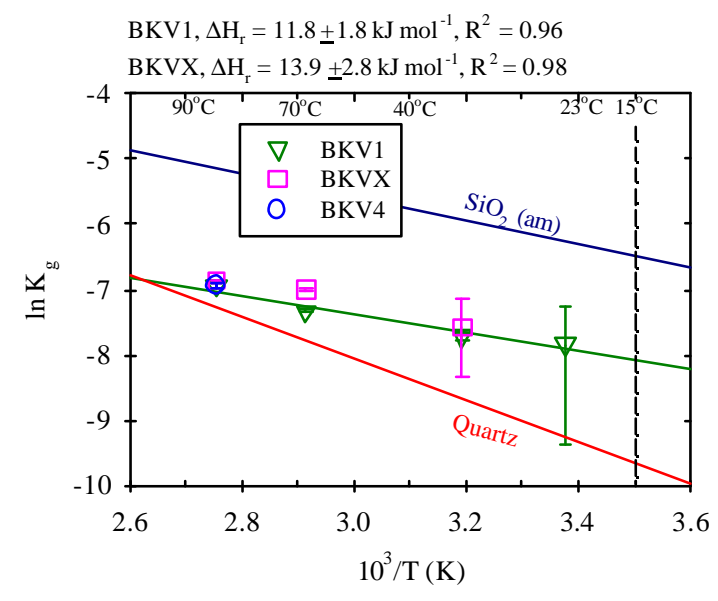

Figure 17: Comparison of $\ln \mathrm{K}_{\mathrm{g}}$ as a Function of Temperature for BKV1, BKVX, and BKV4. 
also provides a crude estimate of the enthalpy of reaction and allows for the value of $K_{g}$ at $15^{\circ} \mathrm{C}$ to be computed. Using the results from these experiments conducted with BKVX resulted in an estimate for $\Delta \mathrm{H}_{\mathrm{r}}$ of $14 \pm 3 \mathrm{~kJ} \mathrm{~mol}^{-1}$ and a computed $\mathrm{K}_{\mathrm{g}}$ value at $15^{\circ} \mathrm{C}$ of $3.31 \times 10^{-4}$ (refer to Table 6).

\subsection{PCT Experiments}

The PCT has been standardized as an

Table 6: Estimate of the Pseudo-Equilibrium Constants for BKVX and BKV4 as a Function of Temperature.

\begin{tabular}{c|c|c|c|c}
\hline $\begin{array}{c}\text { Sample } \\
\text { ID }\end{array}$ & $\mathbf{T}\left({ }^{\circ} \mathbf{C}\right)$ & $\mathbf{K}_{\mathbf{g}}$ & Error & $\mathbf{R}^{2}$ \\
\hline BKVX & 15 & $3.31 \mathrm{E}-4$ & - & - \\
& 40 & $5.11 \mathrm{E}-4$ & $\pm 2.71 \mathrm{E}-4$ & 0.75 \\
& 70 & $9.16 \mathrm{E}-4$ & $\pm 3.16 \mathrm{E}-5$ & 0.76 \\
& 90 & $1.04 \mathrm{E}-3$ & $\pm 2.67 \mathrm{E}-5$ & 0.77 \\
BKV4 & 90 & $9.73 \mathrm{E}-4$ & $\pm 3.08 \mathrm{E}-5$ & 0.71 \\
\hline
\end{tabular}

ASTM standard procedure (ASTM, 1994). The ASTM standard includes two methods: PCT Method A was developed specifically for verifying process control of vitrified high-level waste forms and is conducted with specific values of test parameters; PCT Method B does not specify the values of test parameters. Because the PCT Method B encompasses commonly used variations of test parameters, PCT Method B was used in this work.

\subsubsection{Methods}

The PCTs were conducted by reacting a fixed amount of crushed glass that was sieved to isolate the $-100+200$ mesh size fraction and then cleaned according to ASTM procedure. Two glass surfacearea-to-solution volume ratios (S/V) were used: 1) $1 \mathrm{~g}$ of glass per $10 \mathrm{~mL}$ of deionized water to give an S/V of approximately $2000 \mathrm{~m}^{-1}$, and 2) $1 \mathrm{~g}$ of glass per $1 \mathrm{~mL}$ of deionized water to give an S/V of approximately $20,000 \mathrm{~m}^{-1}$. All experiments were run at $90^{\circ} \mathrm{C}$. To limit water loss for long-duration experiments, the Teflon PFA reactors were sealed inside a stainless steel Parr reactor. At the end of the test, the solution is analyzed for $\mathrm{pH}$ and the concentrations of dissolved glass components. The reacted glass surface was also analyzed to help characterize any alteration phases formed during the test.

\subsubsection{Results for BKV1 Glass}

Figure 18 summarizes the available PCT data on BKV1, BKV4, and BKV5 glass to date for the experiments with $\mathrm{S} / \mathrm{V}$ ratio of $20000 \mathrm{~m}^{-1}$. These results suggest that glass dissolution behavior is entirely normal with no indication of reaction rate acceleration due to secondary phase formation. The normalized mass losses for BKV4 and BKV5 are slightly lower than BKV1 but it is still early in this test ( $<28$ days). Therefore, attempts were made to only model the solution composition data for the experiments conducted using BKV1 glass.

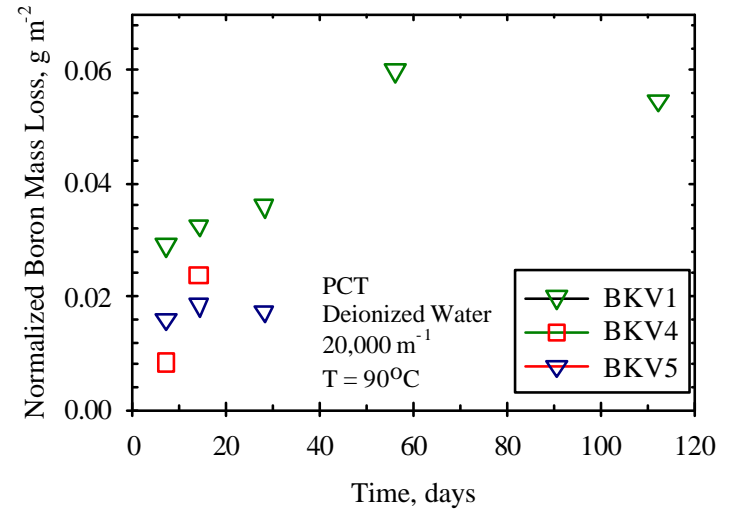

Figure 18. PCT-B Results for BKV1, BKV4, and BKV5 Glasses 


\subsubsection{Modeling With EQ3/6}

Using the boron release data from the PCT experiments with BKV1 glass, a reaction progress value was calculated as a function of test duration. Reaction progress is simply the moles of glass dissolved in $1 \mathrm{~kg}$ of water. The results are shown in Figure 20. Also shown in the Figure 20 is the predicted elemental solution concentration from the EQ3/6 code. Agreement with the experimental data is extraordinarily good. Na was the one exception. To account for $\mathrm{Na}$ release via ion exchange, an initial concentration of $\mathrm{Na}$ was added to the starting solution. Although the present modeling work represents a good start, longer-term PCT data is needed to fully calibrate the chemical reaction network for BV glasses. Solid-phase analyses of reacted solids from the tests also need to be performed to identify any secondary minerals that have not been considered in this initial study.

The predicted secondary phase paragenesis is provided in Figure 19. To adequately reproduce the PCT data, it was necessary to adjust the log K upward for several of the phases [labled as amorphous, e.g., $\left.\mathrm{Fe}(\mathrm{OH})_{3}(\mathrm{am})\right]$. This is a consequence of the fact that amorphous solids rather than their crystalline analogs often form in laboratory experiments with waste glasses. The amorphous solids are typically much more soluble and this is reflected in the equilibrium constant. The log K values assigned to each of the phases used in the simulations are provided in Table 7.

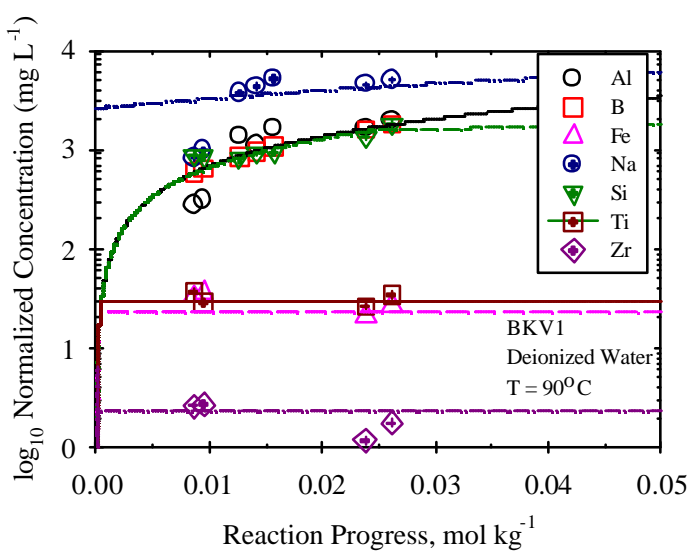

Figure 20: Comparison of PCT Solution Concentration Data (symbols) with the Solution Composition Calculated with the EQ3/6 Code (lines)

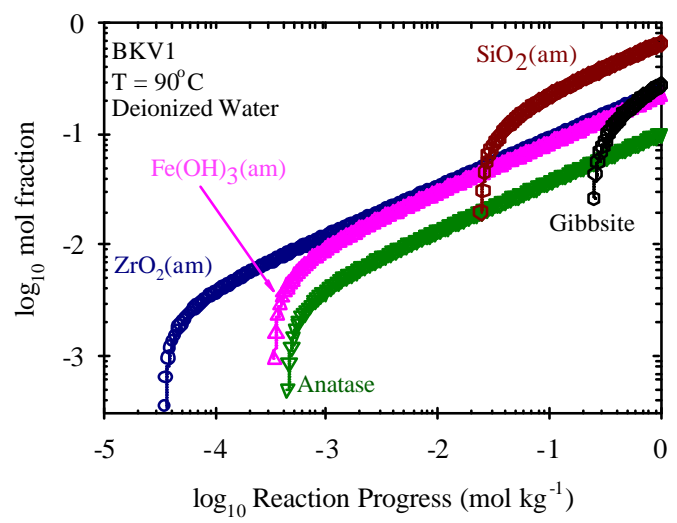

Figure 19: Predicted Paragenetic Sequence of Alteration Phases Formed During the Reaction of BKV1 Glass in Deionized Water. 
Table 7: Secondary Phase Reaction Network for BKV1 Glass. $\log \mathrm{K}$ is calculated at $90^{\circ} \mathrm{C}$.

\begin{tabular}{|c|c|c|}
\hline Phase & Reaction & $\log K$ \\
\hline $\begin{array}{l}\text { Aluminum Hydroxide } \\
\mathrm{Al}(\mathrm{OH})_{3}(\mathrm{am})\end{array}$ & $\mathrm{Al}(\mathrm{OH})_{3}(\mathrm{am})+3 \mathrm{H}^{+}=3 \mathrm{H}_{2} \mathrm{O}+\mathrm{Al}^{3+}$ & 6.34 \\
\hline $\begin{array}{c}\text { Anatase } \\
\mathrm{TiO}_{2}\end{array}$ & $\mathrm{TiO}_{2}+2 \mathrm{H}_{2} \mathrm{O}=\mathrm{Ti}(\mathrm{OH})_{4}^{\circ}(\mathrm{aq})$ & -5.65 \\
\hline $\begin{array}{l}\text { Amorphous Iron Hydroxide } \\
\qquad \mathrm{Fe}(\mathrm{OH})_{3}(\mathrm{am})\end{array}$ & $\mathrm{Fe}(\mathrm{OH})_{3}(\mathrm{am})+2 \mathrm{H}^{+}=2.5 \mathrm{H}_{2} \mathrm{O}+1 \mathrm{Fe}^{2+}+0.25 \mathrm{O}_{2}$ & 2.36 \\
\hline $\mathrm{ZrO}_{2}(\mathrm{am})$ & $\mathrm{ZrO}_{2}(\mathrm{am})+2 \mathrm{H}^{+}=\mathrm{Zr}(\mathrm{OH})_{2}{ }^{2+}$ & -4.65 \\
\hline $\mathrm{SiO}_{2}(\mathrm{am})$ & $\mathrm{SiO}_{2}(\mathrm{am})=\mathrm{SiO}_{2}^{\circ}(\mathrm{aq})$ & -2.23 \\
\hline
\end{tabular}




\subsection{Steam Reformation}

The THOR ${ }^{\text {TM }}$ Fluidized Bed Steam Reformation (FBSR) process operates by introducing high sodium nitrate content tank wastes into a moderate temperature $\left(650-800^{\circ} \mathrm{C}\right)$ fluidized bed. The tank waste is reacted with carbon and iron-based reductants to convert nitrates and nitrites directly to nitrogen gas. Radionuclides, alkali metals, sulfate, chloride, fluoride, and non-volatile heavy metals in the waste stream are reacted with clay (kaolinite) or other inorganic materials to produce a polycrystalline mineral product. Additional details on the process can be found in the report by Jantzen (2002) or at the THOR Treatment Technologies, LLC website (www.thortt.com).

Extensive characterization and testing studies have been performed on a SR product manufactured in a 6-inch diameter, fluidized bed pilot plant at Hazen Research (Golden, Colorado) and the results documented by Jantzen (2002) and McGrail et al (2003b). The SR product sample was granular with grain sizes ranging between 4 $\mathrm{mm}$ and $1 \mathrm{~mm}$ diameter. A picture of a typical SR granule is provided in Figure 21. The primary minerals identified in the product were hexagonal nepheline $\left(\mathrm{NaAlSiO}_{4}\right)$ and nosean $\left[\mathrm{Na}_{8}\left(\mathrm{AlSiO}_{4}\right)_{6} \mathrm{SO}_{4}\right]$; small amounts of hematite, magnetite, and corundum were also detected. From testing data and independent mineral synthesis work (MATTIGOD et al., 2003), Rhenium

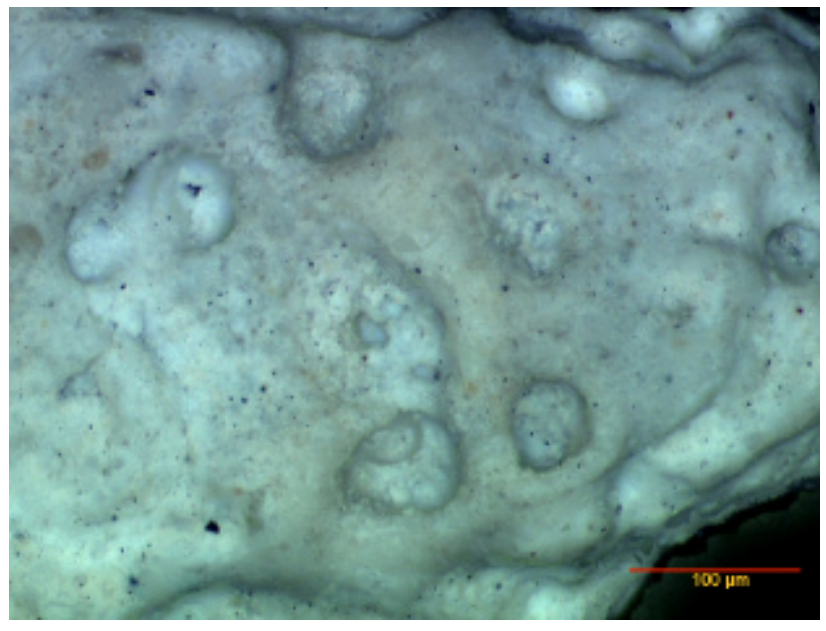

Figure 21. Optical Photograph of SCT02-098 Particle. Black particles are magnetite. [Re] (chemical analog for Tc) was inferred to be located principally in the nosean phase. As will be shown below, additional testing data obtained on the SR product was consistent with this hypothesis.

As discussed by McGrail et al. (2003a), the same kinetic rate equation used for modeling dissolution of WTP and BV glasses will be used for modeling the dissolution kinetics of nepheline and nosean minerals in the SR product. Consequently, the parameters $\vec{k}, \mathrm{E}_{\mathrm{a}}, \eta$, and $K$ need to be determined for both mineral phases. McGrail et al. (2003a) were able to extract a value for $\eta$ for nepheline of 0.25 . As $\eta$ values have little or no detectable temperature dependence for silicate glasses, this assumption was also adopted for nepheline. As experiments were only conducted at one temperature $\left(90^{\circ} \mathrm{C}\right)$ by McGrail et al. (2003a), insufficient data was available for the authors to extract $\vec{k}$, and $\mathrm{E}_{\mathrm{a}}$. Consequently, the additional testing and data reduction required to obtain these parameters are described here. We also include a brief description of the calculation done to compute a $\log K$ value for nosean. The $\log K$ for nepheline was obtained directly from the EQ3NR (WOLERY, 1992b) thermodynamic database. 


\subsection{SR Product Characterization}

The SR product SCT02-098 was subjected to detailed characterization of its physical, bulk chemical and mineralogical properties using a variety of methods. The interested reader should refer to the report by McGrail et al. (2003b) for details on these property measurements. As the identical product was used for the additional testing discussed in this report, no additional product characterization was considered necessary.

\subsection{SPFT Testing}

The experimental procedures and data reduction methods described previously for the BV glasses were used in essentially the same manner for the SR product. Crushing the SR product in an agate mortar and pestle produced the sample used in this study. The crushed material was then sieved to separate the $-100+200$ mesh (149 to $75 \mu \mathrm{m}$ diameter) size fraction and cleaned as described previously. We used $0.5 \pm 0.004 \mathrm{~g}$ of $-100+200$ mesh sample in each reactor; the powder lies at the bottom of the reactor in a thin layer. SPFT experiments were conducted at 70,40 , and $23^{\circ} \mathrm{C}$ with the buffer solution shown in Table 8. Aliquots of effluent solution were routinely checked to ensure that $\mathrm{pH}$ control was maintained during the experiment. The remainder of the effluent solution was acidified by high purity nitric acid and analyzed for chemical composition by ICP-OES and ICP-MS methods. Three blank solutions were drawn before the SR sample was added to the reactor. The blank solutions were analyzed for background concentrations of elements of interest.

Table 8. Composition of Solution Used in SPFT Experiments SR Product. TRIS = THAMbased buffer. Solution $\mathrm{pH}$ values were calculated with the EQ3NR Code V7.2b database.

\begin{tabular}{ccccc} 
Composition & $\mathrm{pH} 23^{\circ} \mathrm{C}$ & $\mathrm{pH} 40^{\circ} \mathrm{C}$ & $\mathrm{pH} 70^{\circ} \mathrm{C}$ & $\mathrm{pH} 90^{\circ} \mathrm{C}$ \\
\hline $0.05 \mathrm{M}$ TRIS + 0.0079 $\mathrm{M} \mathrm{HNO}_{3}$ & 8.97 & 8.44 & 7.78 & 7.42
\end{tabular}

\subsection{SPFT Results}

Each SPFT experiment was run in duplicate. However, we will only show the results from one of the experiments as the data were essentially identical for each replicate test. Detailed results from each test are provided in Appendix C.

As shown in Figure 22, there is a modest temperature dependence on elemental release rates for the SR product. Normalized rates decrease by a factor of about 10X over the temperature interval 90 to $23^{\circ} \mathrm{C}$. A strong correlation between the Re and $\mathrm{S}$ release rates is observed at each temperature, identical to what was observed previously at $90^{\circ} \mathrm{C}$ only. All the test data continue to support our hypothesis that $\mathrm{Re}$ and $\mathrm{S}$ principally reside in the same phase (nosean).

The normalized $\mathrm{Re}$ and $\mathrm{S}$ release rates observed at longer times in the $23^{\circ} \mathrm{C}$ test were significantly lower than at the other temperatures. This experiment may not have been run for sufficient time to reach a true steady-state condition. Both $\mathrm{S}$ and Re release rates are consistently observed to decline at early times in the 90,40 , and $70^{\circ} \mathrm{C}$ tests and then recover to steady-state values near the end of the test. We do not know why this occurs at the present time. However, recovery times are definitely longer at 

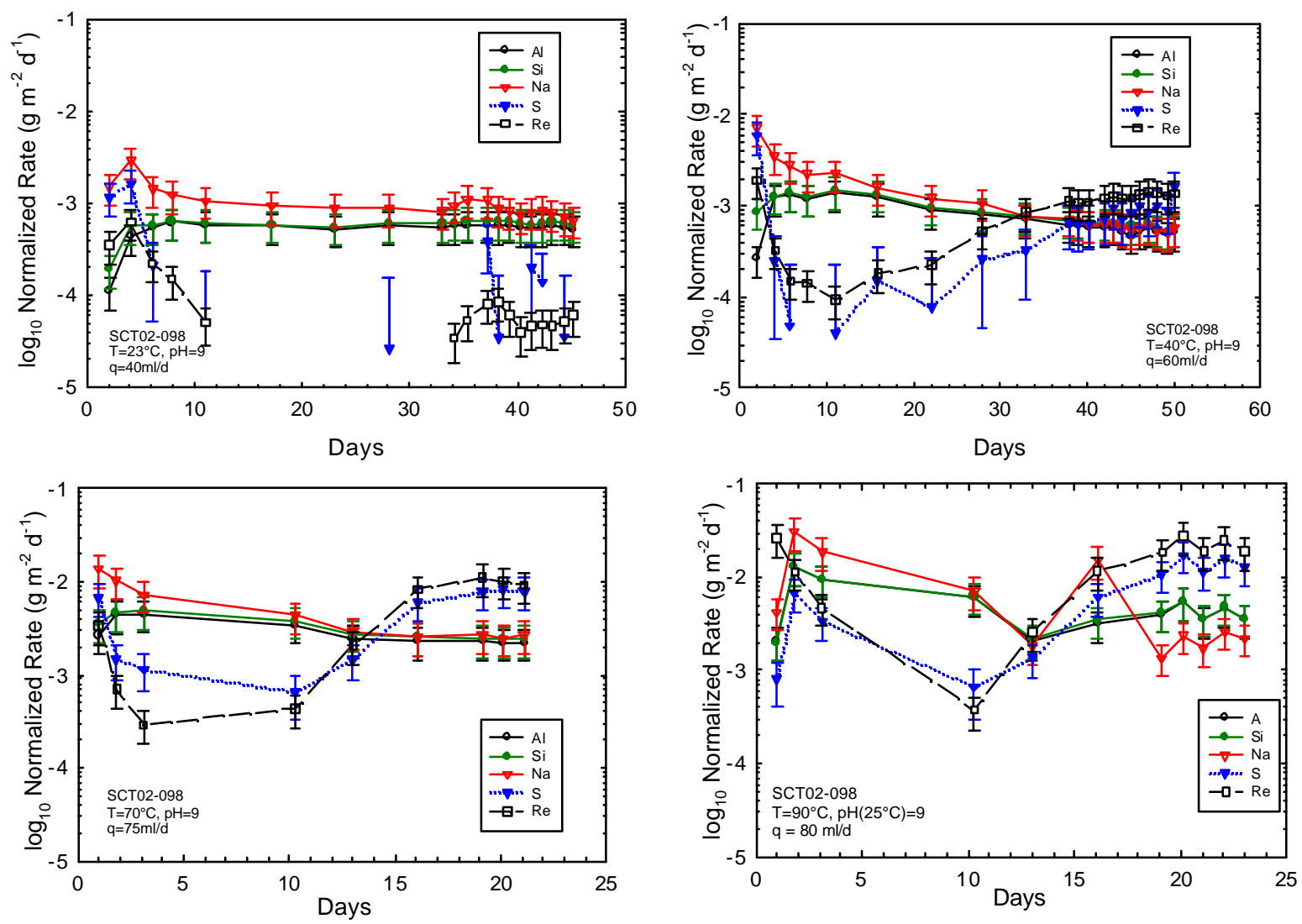

Figure 22. Normalized Release Rate as a Function of Time and Temperature in SPFT Experiments

$40^{\circ} \mathrm{C}$ as compared with $90^{\circ} \mathrm{C}$ and so the $23^{\circ} \mathrm{C}$ experiments would be expected to take even longer to achieve steady-state. Another possible explanation is that solubility effects may be influencing the solution concentration data at $23^{\circ} \mathrm{C}$. To test this hypothesis, the saturation index for nosean was calculated at room temperature with the EQ3NR geochemical computer code (WOLERY, 1992b) and the solubility product given in Section 3.5. The starting solution $\mathrm{pH}\left(23^{\circ} \mathrm{C}\right)$ of 9 was set using $0.05 \mathrm{M}$ TRIS and $0.006 \mathrm{M} \mathrm{HNO}_{3}$. Concentrations of chemical species were input to the code, based on the measured effluent composition from the experiments. At $23^{\circ} \mathrm{C}$, the calculated effluent $\mathrm{pH}$ was 9.03 and a $\log _{10}$ saturation index $(\mathrm{Q} / \mathrm{K})$ of 0.994 for nosean. A $\log (\mathrm{Q} / \mathrm{K})$ greater than zero indicates supersaturation. If the calculated $\log \mathrm{K}$ for nosean is accurate, this would explain why the release rates for $\mathrm{S}$ (and $\mathrm{Re}$ ) are lower than the other components in the $23^{\circ} \mathrm{C}$ tests; $\mathrm{Na}, \mathrm{Si}$, and $\mathrm{Al}$ release rates are dominated by the nepheline but nosean constrains release of $S$ and Re . Saturation indices for nosean at 40, 70, and $90^{\circ} \mathrm{C}$ were many orders of magnitude undersaturated and so the SPFT data reflect true forward dissolution rates. XRD analyses of reacted SR sample after termination of each test showed decreasing $\mathrm{wt} \%$ nosean remaining in the sample with increasing temperature; nosean wt $\%$ decreased to below detectable quantities $(\approx 2 \mathrm{wt} \%)$ by XRD at the highest temperature $\left(90^{\circ} \mathrm{C}\right)$ but was unchanged at $23^{\circ} \mathrm{C}$. 


\subsection{Rate Law Parameter Estimation for Nepheline and Nosean}

Making the assumption that $\mathrm{S}$ is present only in the nosean phase, an estimate of the dissolution rate of the nepheline phase in the SR product can be obtained by differencing. The results from this calculation are presented in Figure 23 as a function of inverse temperature. The data represent the average of the last three samplings at each temperature.

Attempts to perform a non-linear regression with the full rate Equation (15) (neglecting the affinity term) resulted in an ill-conditioned matrix. Consequently, the activation energy was determined with a simple linear regression on the major component release rates from nepheline ( $\mathrm{Na}, \mathrm{Al}$, and $\mathrm{Si})$. The slope $(m)$ is used to compute the activation energy $\left(E_{a}\right)$ from:

$$
m=-\frac{E_{a}}{\mathrm{R}} .
$$

Applying Equation (18), $E_{a}=16.6 \pm 3.4 \mathrm{~kJ} / \mathrm{mol}$. A non-linear regression was then performed using a fixed value of 0.25 for $\eta$ and the regressed $E_{a}$ value. The results gave $\vec{k}=2.0 \times 10^{-9}$ $\pm 2.3 \times 10^{-10} \mathrm{~mol} \mathrm{~m}^{-2} \mathrm{~s}^{-1}$ for nepheline. This value is 2 times higher than the value used for IDF calculations (MANN et al., 2003) because a slightly different method was used to compute $\vec{k}$ prior to completion of this report. However, as discussed in Mann et al. (2003), the exact value of the rate constant for nepheline is unlikely to impact the calculational results significantly.

The regressed value of the activation energy for nepheline dissolution is much lower than reported for dissolution of single-crystal nepheline of between 53 and $77 \mathrm{~kJ} / \mathrm{mol}$ (ToLE et al.,

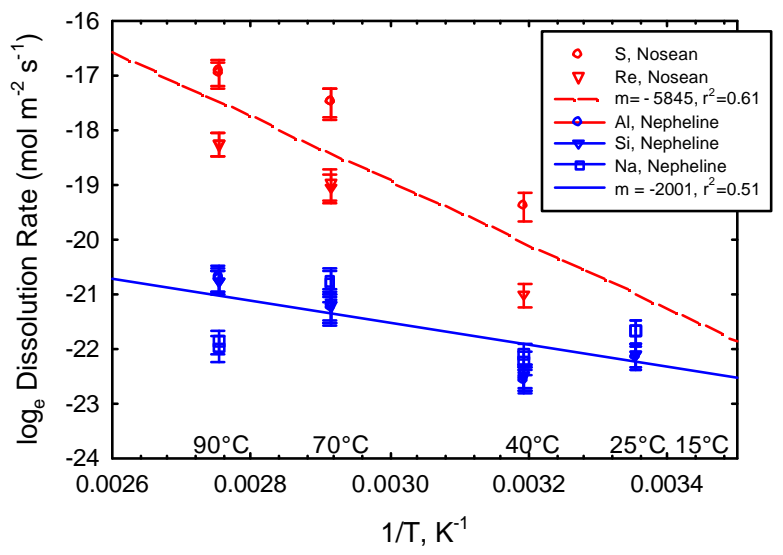

Figure 23. Normalized Release Rate as a Function of Temperature in SPFT Experiments at $\mathrm{pH}\left(25^{\circ} \mathrm{C}\right)$ $=9$. The ordinate is plotted with the natural logarithm; hence Equation (18) is valid for directly computing $E_{a}$ from the slope. 1986). In fact, our data is consistent with the activation energy for free diffusion of water of 17.6 $\mathrm{kJ} / \mathrm{mol}$ (MLLS, 1973). Nepheline is one of the least stable rock-forming minerals with respect to chemical weathering (TOLE et al., 1986; FRANKE and TESCHNERSTEINHARDT, 1994). Our data is certainly consistent with this view as the dissolution rate appears to be controlled simply by the rate that water molecules can diffuse to the mineral surface. We cannot offer an explanation at this time as to why the nepheline phase in the SR product appears to dissolve by a water transport-limited mechanism rather than a bond-breaking mechanism that is common for most silicate minerals. Very low activation energies for dissolution of orthosilicate minerals, such as olivine, have been previously reported (WESTRICH et al., 1993). However, tectosilicates like nepheline have considerably different structure in comparison to orthosilicates so the relevance of these observations is unclear.

The dissolution rate for the nosean phase was obtained by averaging the last three samplings for Re and S shown in Figure 22; the data are also presented in Figure 23. A simple linear regression of the 
Re and $\mathrm{S}$ release data, excluding the values at $23^{\circ} \mathrm{C}$ that are considered unreliable, gives an activation energy of $48.6 \pm 13.6 \mathrm{~kJ} / \mathrm{mol}$ and $\vec{k}=0.25$ (0.002 to 29.7) $\mathrm{mol} \mathrm{m}^{-2} \mathrm{~s}^{-1}$. Clearly, with only three temperatures where reasonably reliable data was available, the regressed rate law parameters for dissolution of nosean are highly uncertain. Additional experiments are needed to improve the estimates. Experiments with a synthesized pure nosean phase are also needed to eliminate potential interactions with the other phases present in the SR product that may be affecting the results.

\subsection{Nosean and Nepheline Solubility Product}

As discussed previously, nosean is an important phase in the SR product as it appears to be the host phase for Re and so by chemical analogy, Tc. However, a solubility product for nosean has not been reported to our knowledge. Consequently, it is necessary to estimate a $\log K$ for nosean.

The temperature dependent solubility product was calculated using the approach outlined by Mattigod and Kittrick (1980). In this approach the temperature dependence of solubility of a mineral is expressed in the form:

$$
\log K_{\mathrm{T}}=1 / 2.303 \mathrm{R}\left[\mathrm{A} \ln \mathrm{T}+\mathrm{BT}+\mathrm{C} / \mathrm{T}^{2}+\mathrm{D} / \mathrm{T}+\mathrm{E}\right]
$$

where $K_{\mathrm{T}}$ is the solubility product at temperature $\mathrm{T}\left({ }^{\circ} \mathrm{K}\right), \mathrm{R}$ is the gas constant, $\mathrm{A}=\Delta \mathrm{a}, \mathrm{B}=\Delta \mathrm{b} / 2$, $\mathrm{C}=\Delta \mathrm{c} / 2, \mathrm{D}=\left[\Delta \mathrm{a} \mathrm{T}_{\mathrm{r}}+(\Delta \mathrm{b} / 2) \mathrm{T}_{\mathrm{r}}^{2}-\Delta \mathrm{c} / \mathrm{T}_{\mathrm{r}}-\Delta \mathrm{S}^{0} \mathrm{~T}_{\mathrm{r}}+\mathrm{RT} \ln \mathrm{K}_{\mathrm{Tr}}\right]$, and $\mathrm{E}=\left[-\Delta \mathrm{a}-\Delta \mathrm{a} \ln \mathrm{T}_{\mathrm{r}}-\Delta \mathrm{b} \mathrm{T}_{\mathrm{r}}+\right.$ $\left.\left(\Delta \mathrm{c} / 2 \mathrm{~T}_{\mathrm{r}}^{2}\right)+\Delta \mathrm{S}^{0}\right]$, and $\Delta \mathrm{a}, \Delta \mathrm{b}$, and $\Delta \mathrm{c}$ are the heat capacity of reaction coefficients from the MeierKelly equation

$$
\mathrm{C}_{\mathrm{p}}=\Delta \mathrm{a}+\Delta \mathrm{bT}+\Delta \mathrm{c} / \mathrm{T}^{2}
$$

where $\Delta \mathrm{S}^{0}=$ entropy of reaction

$$
K_{\mathrm{Tr}}=\text { solubility product at a reference temperature }(298.15 \mathrm{~K}) \text {. }
$$

The dissolution/precipitation reaction for nosean is expressed in the form:

$$
\mathrm{Na}_{8} \mathrm{Al}_{6} \mathrm{Si}_{6} \mathrm{O}_{24}\left(\mathrm{SO}_{4}\right)+24 \mathrm{H}^{+}=8 \mathrm{Na}^{+}+6 \mathrm{Al}^{3+}+6 \mathrm{SiO}_{2}(\mathrm{aq})+\mathrm{SO}_{4}{ }^{2-}+12 \mathrm{H}_{2} \mathrm{O}
$$


Using Kirchhoff's law, the Gibbs free energy of reaction was calculated as a function of temperature using the thermodynamic data provided in Table 9.

The solubility product was then calculated using the expression

$$
\ln \mathrm{K}(\mathrm{T})=-\Delta \mathrm{G}^{\mathrm{o}} / 2.479
$$

where $\Delta \mathrm{G}^{\circ}$ is the free energy of reaction. The resulting values for $\log K(\mathrm{~T})$ are given in Table 10 .

The $\log K$ at $15^{\circ} \mathrm{C}$ is 51.8 given the reaction written as Equation (21). Because $\mathrm{pH}$ values are expected to be well above $\mathrm{pH} 4$ in the disposal system, $\mathrm{AlO}_{2}^{-}$is the dominant solution species. Consequently, the $\log K\left(15^{\circ} \mathrm{C}\right)$ value (-92.1) used for the IDF simulations (MANN et al., 2003) reflects a correction for the reaction:

$\mathrm{Al}^{3+}+2 \mathrm{H}_{2} \mathrm{O}=\mathrm{AlO}_{2}^{-}+4 \mathrm{H}^{+} \quad \log _{10} K\left(15^{\circ} \mathrm{C}\right)=-23.98$.

The dissolution/precipitation reaction for nepheline is

$\mathrm{NaAlSiO}_{4}(\mathrm{~s})+4 \mathrm{H}^{+}=\mathrm{Na}^{+}+\mathrm{AlO}_{2}^{-}+\mathrm{SiO}_{2}(\mathrm{aq})$.

The $\log K\left(15^{\circ} \mathrm{C}\right)$ is -9.4 as obtained directly from the EQ3NR database, GEMBOCHS.V2-EQ8-DATA0.
Table 10. Temperaturedependent Solubility Constants for Nosean

$\begin{array}{crr}\frac{\mathrm{T}\left({ }^{\circ} \mathrm{C}\right)}{15} & & \frac{\log K}{51.8} \\ 25 & 52.1 \\ 35 & 52.4 \\ 45 & 52.7 \\ 55 & 53.0 \\ 65 & 53.3 \\ 75 & 53.7 \\ 85 & 53.9 \\ 95 & 54.3\end{array}$

Table 9. Thermodynamic Data Used for Calculating Temperature-Dependence of Nosean Solubility

\begin{tabular}{|c|c|c|c|c|c|}
\hline \multirow[t]{2}{*}{ Species } & \multirow[t]{2}{*}{$\begin{array}{c}\Delta \mathrm{G}_{\mathrm{f}}^{0} \\
(\mathrm{~kJ} / \mathrm{mol})\end{array}$} & \multirow[t]{2}{*}{$\begin{array}{l}\Delta \mathrm{S}_{298.15}^{0} \\
(\mathrm{~J} / \mathrm{mol} \mathrm{deg})\end{array}$} & \multicolumn{3}{|c|}{$\begin{array}{c}\mathrm{C}_{\mathrm{p}}=\mathrm{a}+\mathrm{bT}+\mathrm{c} / \mathrm{T}^{2} \\
(\mathrm{~J} / \mathrm{mol} \mathrm{deg})\end{array}$} \\
\hline & & & $\Delta \mathrm{a}$ & $\Delta \mathrm{b} \times 10^{3}$ & $\Delta \mathrm{c} \times 10^{-5}$ \\
\hline $\begin{array}{l}\mathrm{Na}_{8} \mathrm{Al}_{6} \mathrm{Si}_{6} \mathrm{O}_{24}\left(\mathrm{SO}_{4}\right) \\
\text { (nosean) }\end{array}$ & -13300.5 & 806 & 1047.9 & 158.56 & -241.20 \\
\hline $\mathrm{Na}^{+}(\mathrm{aq})$ & -261.90 & 59.00 & 0 & 155.64 & 0 \\
\hline $\mathrm{Al}^{3+}(\mathrm{aq})$ & -485.00 & -321.70 & 0 & 128.03 & 0 \\
\hline $\mathrm{SO}_{4}{ }^{2-}(\mathrm{aq})$ & -744.50 & 17.57 & 0 & -1004.16 & 0 \\
\hline $\mathrm{SiO}_{2}(\mathrm{aq})$ & -833.8 & 40.18 & -99.3 & 611.03 & -16.88 \\
\hline $\mathrm{H}_{2} \mathrm{O}$ (liq) & -237.14 & 69.91 & 49.66 & 54.31 & 8.44 \\
\hline
\end{tabular}




\subsection{Conclusion}

In this report, we have documented the testing that has been accomplished to date of bulk vitrified and steam reformed low-activity waste forms. The test data have been reduced to a set of parameters that have been utilized in reactive chemical transport simulations of an integrated disposal facility. The reader should consult Mann et al. (2003) for a description of the results from those calculations. The reader is strongly cautioned not to directly utilize the test data in this report to draw conclusions about the long-term performance of either waste form. 



\subsection{References}

ASTM. 1994. Standard Test Methods for Determining Chemical Durability of Nuclear Waste Glasses: The Product Consistency Test (PCT). ASTM C1285, American Society for Testing and Materials, Philadelphia, Pennsylvania.

Bacon, D. H., M. D. White, and B. P. McGrail. 2000. Subsurface Transport Over Reactive Multiphases (STORM): A General, Coupled Nonisothermal Multiphase Flow, Reactive Transport, and Porous Medium Alteration Simulator, Version 2, User's Guide. PNNL-13108, Pacific Northwest National Laboratory, Richland, Washington.

Carroll, S. A. and J. Bruno. 1991. "Mineral-Solution Interactions in the U(VI)-CO2-H2O System." Radiochimica Acta 52/53:187-193.

Chou, L. and R. Wollast. 1984. "Study of the weathering of albite at room temperature and pressure with a fluidized bed reactor." Geochimica et Cosmochimica Acta 48:2205-2217.

Darab, J. G. and P. A. Smith. 1996. "Chemistry of Technetium and Rhenium Species During LowLevel Radioactive Waste Vitrification." Chem. Mater. 8:1004-1021.

DOE. 2002. Performance Management Plan for the Accelerated Cleanup of the Hanford Site. DOE/RL-2002-47, Revision D, U.S. Department of Energy, Richland, Washington, URL= http://www.hanford.gov/docs/rl-2002-47/rl-2002-47.pdf.

Dove, P. M. 1994. "The Dissolution Kinetics of Amorphous Silica Into Sodium Chloride Solutions: Effects of Temperature and Ionic Strength." American Journal of Science 294:665 - 712.

Franke, W. A. and R. Teschnersteinhardt. 1994. "An Experimental Approach to the Sequence of the Stability of Rock-Forming Minerals Towards Chemical Weathering." Catena 21(2-3):279-290.

Holdren, G. R. and P. M. Speyer. 1987. "Reaction Rate-Surface Area Relationships during the Early Stages of Weathering. II. Data on Eight Additional Feldspars." Geochimica et Cosmochimica Acta 51(9):2311-2318.

Icenhower, J. P. and P. M. Dove. 2000. "The dissolution kinetics of amorphous silica into sodium chloride solutions: Effects of temperature and ionic strength." Geochimica et Cosmochimica Acta 64(24):4193-4203.

Jantzen, C. M. 2002. Engineering Study of the Hanford Low Activity Waste (LAW) Steam Reforming Process. WSRC-TR-2002-00317, Rev. 0, Westinghouse Savannah River Company, Aiken, South Carolina.

Kim, D.-S., J. D. Vienna, P. R. Hrma, M. J. Schweiger, J. Matyáš, J. V. Crum, D. E. Smith, G. J. Sevigny, W. C. Buchmiller, J. S. Tixier, V. J. Yeager, and K. B. Belew. 2003. Development and Testing of ICV Glasses for Hanford LAW. PNNL-14351, Pacific Northwest National Laboratory, Richland, Washington.

Lasaga, A. C. K., R. J. 1981. "Kinetics of Geochemical Processes." In Reviews in Mineralogy, Vol. 8 (ed. P. H. Ribbe),Washington D. C. Web 
Luey, J. and D. K. Seiler. 1995. Application of In Situ Vitrification in the Soil Subsurface: Engineering-Scale Testing. PNL-10485, Pacific Northwest Laboratory, Richland, Washington.

Mann, F. M., B. P. McGrail, D. H. Bacon, R. J. Serne, K. M. Krupka, R. J. Puigh, R. Khaleel, and S. H. Finfrock. 2003. Risk Assessment Supporting the Decision on the Initial Selection of Supplemental ILAW Technologies. RPP-17675, Rev. 0, CH2M Hill Hanford Group, Inc., Richland, Washington.

Mattigod, S. V. and J. A. Kittrick. 1980. "Temperature and Water Activity as Variables in Soil Mineral Activity Diagrams." Soil Sci. Soc. Am. J. 44:149-154.

Mattigod, S. V., B. P. McGrail, D. M. McCready, and K. E. Parker. 2003. "Synthesis and Structure of Perrhenate Sodalite." Chem. Mat. In press.

McGrail, B. P., D. H. Bacon, J. P. Icenhower, W. L. Ebert, P. F. Martin, H. T. Schaef, and E. A. Rodriguez. 2001a. Waste Form Release Data Package for the 2001 Immobilized Low-Activity Waste Performance Assessment. PNNL-13043, Rev. 2, Pacific Northwest National Laboratory, Richland, Washington.

McGrail, B. P., D. H. Bacon, R. J. Serne, and E. M. Pierce. 2003a. A Strategy to Assess Performance of Selected Low-Activity Waste Forms in an Integrated Disposal Facility. PNNL-14362, Pacific Northwest National Laboratory, Richland, Washington.

McGrail, B. P., W. L. Ebert, A. J. Bakel, and D. K. Peeler. 1997. "Measurement of kinetic rate law parameters on a Na-Ca-Al borosilicate glass for low-activity waste." Journal of Nuclear Materials 249:175-189.

McGrail, B. P., J. P. Icenhower, and P. F. Martin. 2000. Low-Activity Waste Glass Studies: FY2000 Summary Report. PNNL, Richland, Wa.

McGrail, B. P., J. P. Icenhower, D. K. Shuh, P. Liu, J. G. Darab, D. R. Baer, S. Thevuthasen, V. Shutthanandan, M. H. Engelhard, C. H. Booth, and P. Nachimuthu. 2001b. "The Structure of $\mathrm{Na}_{2} \mathrm{O}-$ $\mathrm{Al}_{2} \mathrm{O}_{3}-\mathrm{SiO}_{2}$ Glass: Impact on Sodium Ion Exchange in $\mathrm{H}_{2} \mathrm{O}$ and $\mathrm{D}_{2} \mathrm{O}$." J. Non-Cryst. Solids 296(12):10-26.

McGrail, B. P., H. T. Schaef, P. F. Martin, D. H. Bacon, E. A. Rodriguez, D. E. McCready, and A. R. Primak. 2003b. Initial Suitability Evaluation of Steam-Reformed Low Activity Waste for Direct Land Disposal. WTP-RPT-097, Battelle, Pacific Northwest Division, Richland, Washington.

Mills, R. 1973. "Self-Diffusion in Normal and Heavy Water in the Range 1-45'." J. Physical Chem. 77(5):685-688.

Reidel, S. P., V. G. Johnson, and F. A. Spane. 2002. Natural Gas Storage in Basalt Aquifers of the Columbia Basin, Pacific Northwest USA: A Guide to Site Characterization. PNNL-13962, Pacific Northwest National Laboratory, Richland, Washington.

Renders, P. J. N. G., C.H.; and Barnes, H.L. 1995. "Precipitation and Dissolution Rate Constants for Cristobalite From 150 to $300^{\circ}$ C." Geochimica et Cosmochimica Acta 59( ):77-85.

Tixier, J. S., J. A. Stottlemyre, and M. T. Murphy. 1991. "Vitrified Underground Barriers." Waste Management '91, pp. 603-611. 
Tole, M. P., A. C. Lasaga, C. Pantano, and W. B. White. 1986. "The Kinetics of Dissolution of Nepheline (NaAlSiO 4$)$." Geochim. Cosmochim. Acta 50(3):379-392.

Westrich, H. R., R. T. Cygan, W. H. Casey, C. Zemitis, and G. W. Arnold. 1993. "The Dissolution Kinetics of Mixed-Cation Orthosilicate Minerals." Am. J. Sci. 293(9):869-893.

Wolery, T. J. 1992a. EQ3NR, A Computer Program for Geochemical Aqueous SpeciationSolubility Calculations: Theoretical Manual, User's Guide, and Related Documentation (Version 7.0). UCRL-MA-110662 PT III, LLNL, Livermore, CA.

Wolery, T. J. 1992b. EQ3NR, A Computer Program for Geochemical Aqueous SpeciationSolubility Calculations: Theoretical Manual, User's Guide, and Related Documentation (Version 7.0). UCRL-MA-110662 PT III, Lawrence Livermore National Laboratory, Livermore, California. 


\subsection{Appendix A. Bulk Vitrified Product Chemical Analysis}

Table A1. Results of Analyses of BKV1 $1^{\mathrm{a}}$.

\begin{tabular}{|c|c|c|c|c|c|}
\hline Oxide & $\begin{array}{l}\mathrm{LiBO}_{2} \\
\text { Fusion }\end{array}$ & $\begin{array}{l}\mathrm{Na}_{2} \mathrm{O}_{2} \\
\text { Fusion }\end{array}$ & $\begin{array}{l}\mathrm{LiBO}_{2} \\
\text { Fusion }\end{array}$ & $\begin{array}{l}\mathrm{Na}_{2} \mathrm{O}_{2} \\
\text { Fusion }\end{array}$ & $\begin{array}{c}\text { BKV1 } \\
\text { Powder }\end{array}$ \\
\hline $\mathrm{Al}_{2} \mathrm{O}_{3}$ & 2.970 & 9.887 & $\mathrm{ND}^{\mathrm{b}}$ & ND & 8.111 \\
\hline $\mathrm{B}_{2} \mathrm{O}_{3}$ & ND & 6.198 & ND & ND & 4.316 \\
\hline $\mathrm{CaO}$ & 16.563 & 3.495 & ND & ND & 2.109 \\
\hline $\mathrm{Cl}$ & ND & ND & ND & ND & 0.034 \\
\hline $\mathrm{Cr}_{2} \mathrm{O}_{3}$ & 0.005 & 0.094 & ND & ND & 0.092 \\
\hline $\mathrm{Fe}_{2} \mathrm{O}_{3}$ & 1.852 & 3.844 & ND & ND & 3.564 \\
\hline $\mathrm{K}_{2} \mathrm{O}$ & 0.693 & 2.145 & ND & ND & 1.161 \\
\hline $\mathrm{MgO}$ & 0.080 & 1.133 & ND & ND & 1.341 \\
\hline $\mathrm{Na}_{2} \mathrm{O}$ & 25.10 & ND & ND & ND & 20.85 \\
\hline $\mathrm{P}_{2} \mathrm{O}_{5}$ & 0.899 & 0.414 & ND & ND & 0.533 \\
\hline $\mathrm{ReO}_{2}$ & ND & ND & $B L Q^{c}$ & 0.0012 & $<0.0013$ \\
\hline $\mathrm{SO}_{3}$ & 1.0198 & $B L Q$ & ND & ND & 0.366 \\
\hline $\mathrm{SiO}_{2}$ & 45.06 & 45.79 & ND & ND & 49.53 \\
\hline $\mathrm{TiO}_{2}$ & 0.982 & 0.686 & ND & ND & 0.567 \\
\hline $\mathrm{ZrO}_{2}$ & 0.106 & 5.841 & ND & ND & 7.055 \\
\hline Technique & ICP-OES & ICP-OES & ICP-MS & ICP-MS & XRF \\
\hline
\end{tabular}

${ }^{\mathrm{a}}$ Results noted in italics were not used in calculations of the reported mean composition.

${ }^{\mathrm{b}} \mathrm{ND}=$ Not Determined

${ }^{\mathrm{c}}$ BLQ=Below Limit of Quantification

Table A2. Results of Analyses of BKV2 ${ }^{\mathrm{a}}$.

\begin{tabular}{|c|c|c|c|c|c|}
\hline Oxide & $\begin{array}{l}\mathrm{LiBO}_{2} \\
\text { Fusion }\end{array}$ & $\begin{array}{l}\mathrm{Na}_{2} \mathrm{O}_{2} \\
\text { Fusion }\end{array}$ & $\begin{array}{l}\mathrm{LiBO}_{2} \\
\text { Fusion }\end{array}$ & $\begin{array}{l}\mathrm{Na}_{2} \mathrm{O}_{2} \\
\text { Fusion }\end{array}$ & $\begin{array}{c}\text { BKV2 } \\
\text { Powder }\end{array}$ \\
\hline $\mathrm{Al}_{2} \mathrm{O}_{3}$ & 10.03 & 7.278 & $\mathrm{ND}^{\mathrm{b}}$ & ND & 6.974 \\
\hline $\mathrm{B}_{2} \mathrm{O}_{3}$ & ND & 5.116 & ND & ND & 3.1421 \\
\hline $\mathrm{CaO}$ & 3.1889 & 2.922 & ND & ND & 1.687 \\
\hline $\mathrm{Cl}$ & ND & ND & ND & ND & 0.0647 \\
\hline $\mathrm{Cr}_{2} \mathrm{O}_{3}$ & 0.098 & 0.053 & ND & ND & 0.0490 \\
\hline $\mathrm{Fe}_{2} \mathrm{O}_{3}$ & 3.988 & 2.579 & ND & ND & 2.24 \\
\hline $\mathrm{K}_{2} \mathrm{O}$ & 2.1705 & 1.643 & ND & ND & 0.99 \\
\hline $\mathrm{MgO}$ & 1.2911 & 0.839 & ND & ND & 1.19 \\
\hline $\mathrm{Na}_{2} \mathrm{O}$ & 21.6895 & ND & ND & ND & 14.68 \\
\hline $\mathrm{P}_{2} \mathrm{O}_{5}$ & 0.41 & 0.16 & ND & ND & 0.199 \\
\hline $\mathrm{ReO}_{2}$ & ND & ND & $\mathrm{BLQ}^{\mathrm{c}}$ & 0.0016 & $<0.001$ \\
\hline $\mathrm{SO}_{3}$ & 0.764 & BLQ & ND & ND & 0.1363 \\
\hline $\mathrm{SiO}_{2}$ & 43.91 & 40.08 & ND & ND & 63.50 \\
\hline $\mathrm{TiO}_{2}$ & 0.726 & 0.493 & ND & ND & 0.4513 \\
\hline $\mathrm{ZrO}_{2}$ & 6.385 & 2.543 & ND & ND & 4.46 \\
\hline Technique & ICP-OES & ICP-OES & ICP-MS & ICP-MS & $\mathrm{XRF}$ \\
\hline
\end{tabular}

${ }^{\text {a }}$ Results noted in italics were not used in calculations of the reported mean composition.

${ }^{\mathrm{b}} \mathrm{ND}=$ Not Determined

${ }^{\mathrm{c}} \mathrm{BLQ}=$ Below Limit of Quantification 
Table A3. Results of Analyses of BKVX'.

\begin{tabular}{|c|c|c|c|c|c|}
\hline Oxide & $\begin{array}{l}\mathrm{LiBO}_{2} \\
\text { Fusion }\end{array}$ & $\begin{array}{l}\mathrm{Na}_{2} \mathrm{O}_{2} \\
\text { Fusion }\end{array}$ & $\begin{array}{l}\mathrm{LiBO}_{2} \\
\text { Fusion }\end{array}$ & $\begin{array}{l}\mathrm{Na}_{2} \mathrm{O}_{2} \\
\text { Fusion }\end{array}$ & $\begin{array}{l}\text { BKVX } \\
\text { Powder }\end{array}$ \\
\hline $\mathrm{Al}_{2} \mathrm{O}_{3}$ & 7.2747 & 7.8536 & $\mathrm{ND}^{\mathrm{b}}$ & ND & 7.377 \\
\hline $\mathrm{B}_{2} \mathrm{O}_{3}$ & ND & 5.2690 & ND & ND & 2.9559 \\
\hline $\mathrm{CaO}$ & 2.7371 & 3.0272 & ND & ND & 1.686 \\
\hline $\mathrm{Cl}$ & ND & ND & ND & ND & 0.0309 \\
\hline $\mathrm{Cr}_{2} \mathrm{O}_{3}$ & 0.0521 & 0.0571 & ND & ND & 0.0466 \\
\hline $\mathrm{Fe}_{2} \mathrm{O}_{3}$ & 2.607 & 2.748 & ND & ND & 2.32 \\
\hline $\mathrm{K}_{2} \mathrm{O}$ & 1.6839 & 1.7663 & ND & ND & 1.01 \\
\hline $\mathrm{MgO}$ & 0.9833 & 0.9570 & ND & ND & 1.16 \\
\hline $\mathrm{Na}_{2} \mathrm{O}$ & 21.3457 & ND & ND & ND & 14.82 \\
\hline $\mathrm{P}_{2} \mathrm{O}_{5}$ & 0.21 & 0.15 & ND & ND & 0.213 \\
\hline $\mathrm{ReO}_{2}$ & ND & ND & 0.0006 & 0.0018 & 0.0015 \\
\hline $\mathrm{SO}_{3}$ & 0.0400 & $\mathrm{BLQ}^{\mathrm{c}}$ & ND & ND & 0.1520 \\
\hline $\mathrm{SiO}_{2}$ & 57.28 & 52.57 & ND & ND & 62.69 \\
\hline $\mathrm{TiO}_{2}$ & 0.516 & 0.522 & ND & ND & 0.4387 \\
\hline $\mathrm{ZrO}_{2}$ & 4.1459 & 2.8833 & ND & ND & 4.83 \\
\hline Technique & ICP-OES & ICP-OES & ICP-MS & ICP-MS & $\mathrm{XRF}$ \\
\hline
\end{tabular}

${ }^{\text {a }}$ Results noted in italics were not used in calculations of the reported mean composition.

${ }^{\mathrm{b}} \mathrm{ND}=$ Not Determined

${ }^{\mathrm{c}} \mathrm{BLQ}=$ Below Limit of Quantification

Table A4. Results of Analyses of $\mathrm{BKV}^{\mathrm{a}}$.

\begin{tabular}{cccccc}
\hline & $\mathrm{LiBO}_{2}$ & $\mathrm{Na}_{2} \mathrm{O}_{2}$ & $\mathrm{LiBO}_{2}$ & $\mathrm{Na}_{2} \mathrm{O}_{2}$ & $\mathrm{BKV}^{2}$ \\
Oxide & Fusion & Fusion & Fusion & Fusion & Powder \\
\hline $\mathrm{Al}_{2} \mathrm{O}_{3}$ & 9.786 & 10.01 & $\mathrm{ND}^{\mathrm{b}}$ & $\mathrm{ND}$ & 9.042 \\
$\mathrm{~B}_{2} \mathrm{O}_{3}$ & $\mathrm{ND}$ & 6.158 & $\mathrm{ND}$ & $\mathrm{ND}$ & 3.762 \\
$\mathrm{CaO}$ & 2.919 & 3.427 & $\mathrm{ND}$ & $\mathrm{ND}$ & 2.258 \\
$\mathrm{Cl}$ & $\mathrm{ND}$ & $\mathrm{ND}$ & $\mathrm{ND}$ & $\mathrm{ND}$ & 0.046 \\
$\mathrm{Cr}_{2} \mathrm{O}_{3}$ & 0.0339 & 0.0314 & $\mathrm{ND}$ & $\mathrm{ND}$ & 0.030 \\
$\mathrm{Fe}_{2} \mathrm{O}_{3}$ & 3.906 & 3.872 & $\mathrm{ND}$ & $\mathrm{ND}$ & 3.472 \\
$\mathrm{~K}_{2} \mathrm{O}$ & 2.309 & 2.306 & $\mathrm{ND}$ & $\mathrm{ND}$ & 1.376 \\
$\mathrm{MgO}^{\mathrm{O} O}$ & 1.2287 & 1.122 & $\mathrm{ND}$ & $\mathrm{ND}$ & 1.331 \\
$\mathrm{Na}_{2} \mathrm{O}$ & 26.31 & $\mathrm{ND}$ & $\mathrm{ND}$ & $\mathrm{ND}$ & 18.44 \\
$\mathrm{P}_{2} \mathrm{O}_{5}$ & 0.26 & 0.31 & $\mathrm{ND}$ & $\mathrm{ND}$ & 0.233 \\
$\mathrm{ReO}_{2}$ & $\mathrm{ND}$ & $\mathrm{ND}$ & $\mathrm{BLQ}$ & 0.0001 & $<0.002$ \\
$\mathrm{SO}_{3}$ & 0.8034 & $\mathrm{BLQ}$ & $\mathrm{ND}$ & $\mathrm{ND}$ & 0.1598 \\
$\mathrm{SiO}_{2}$ & 51.84 & 49.75 & $\mathrm{ND}$ & $\mathrm{ND}$ & 52.82 \\
$\mathrm{TiO}_{2}$ & 0.713 & 0.695 & ND & ND & 0.575 \\
$\mathrm{ZrO}_{2}$ & 6.759 & 6.231 & ND & ND & 6.121 \\
$\mathrm{Technique}^{\mathrm{c}}$ & $\mathrm{ICP}-\mathrm{OES}$ & $\mathrm{ICP}-\mathrm{OES}$ & $\mathrm{ICP}-\mathrm{MS}$ & ICP-MS & XRF \\
\hline
\end{tabular}

${ }^{\text {a }}$ Results noted in italics were not used in calculations of the reported mean composition.

${ }^{\mathrm{b}} \mathrm{ND}=$ Not Determined

${ }^{c}$ BLQ=Below Limit of Quantification 
Table A5. Results of Analyses of BKV4 $4^{\mathrm{a}}$.

\begin{tabular}{cccccc}
\hline & $\mathrm{LiBO}_{2}$ & $\mathrm{Na}_{2} \mathrm{O}_{2}$ & $\mathrm{LiBO}_{2}$ & $\mathrm{Na}_{2} \mathrm{O}_{2}$ & BKV4 \\
Oxide & Fusion & Fusion & Fusion & Fusion & Powder \\
\hline $\mathrm{Al}_{2} \mathrm{O}_{3}$ & 9.329 & 9.403 & $\mathrm{ND}^{\mathrm{b}}$ & $\mathrm{ND}$ & 8.652 \\
$\mathrm{~B}_{2} \mathrm{O}_{3}$ & $\mathrm{ND}$ & 6.514 & $\mathrm{ND}$ & $\mathrm{ND}$ & 3.0560 \\
$\mathrm{CaO}$ & 3.077 & 3.421 & $\mathrm{ND}$ & $\mathrm{ND}$ & 2.399 \\
$\mathrm{Cl}$ & $\mathrm{ND}$ & $\mathrm{ND}$ & $\mathrm{ND}$ & $\mathrm{ND}$ & 0.038 \\
$\mathrm{Cr}_{2} \mathrm{O}_{3}$ & 0.052 & 0.058 & $\mathrm{ND}$ & $\mathrm{ND}$ & 0.048 \\
$\mathrm{Fe}_{2} \mathrm{O}_{3}$ & 4.609 & 4.624 & $\mathrm{ND}$ & $\mathrm{ND}$ & 4.15 \\
$\mathrm{~K}_{2} \mathrm{O}$ & 2.087 & 1.937 & $\mathrm{ND}$ & $\mathrm{ND}$ & 1.23 \\
$\mathrm{MgO}^{\mathrm{O} O}$ & 1.365 & 1.226 & $\mathrm{ND}$ & $\mathrm{ND}$ & 1.49 \\
$\mathrm{Na}_{2} \mathrm{O}$ & 16.34 & $\mathrm{ND}$ & $\mathrm{ND}$ & $\mathrm{ND}$ & 10.41 \\
$\mathrm{P}_{2} \mathrm{O}_{5}$ & 0.318 & 0.213 & $\mathrm{ND}$ & $\mathrm{ND}$ & 0.291 \\
$\mathrm{ReO}_{2}$ & $\mathrm{ND}$ & $\mathrm{ND}$ & 0.0019 & 0.0024 & $<0.001$ \\
$\mathrm{SO}_{3}$ & 0.962 & $\mathrm{BLQ}$ & $\mathrm{ND}$ & $\mathrm{ND}$ & 0.067 \\
$\mathrm{SiO}_{2}$ & 57.80 & 50.36 & $\mathrm{ND}$ & $\mathrm{ND}$ & 61.43 \\
$\mathrm{TiO}_{2}$ & 0.857 & 0.831 & $\mathrm{ND}$ & $\mathrm{ND}$ & 0.689 \\
$\mathrm{ZrO}_{2}$ & 6.375 & 5.280 & ND & ND & 5.72 \\
$\mathrm{Technique}^{\mathrm{c}}$ & $\mathrm{ICP}-\mathrm{OES}$ & $\mathrm{ICP}-\mathrm{OES}$ & $\mathrm{ICP}-\mathrm{MS}$ & $\mathrm{ICP}-\mathrm{MS}$ & XRF \\
\hline
\end{tabular}

${ }^{\mathrm{a}}$ Results noted in italics were not used in calculations of the reported mean composition.

${ }^{\mathrm{b}} \mathrm{ND}=$ Not Determined

${ }^{\mathrm{c}} \mathrm{BLQ}=$ Below Limit of Quantification

Table A6. Results of Analyses of BKV5 $5^{\mathrm{a}}$.

\begin{tabular}{cccccc}
\hline & $\mathrm{LiBO}_{2}$ & $\mathrm{Na}_{2} \mathrm{O}_{2}$ & $\mathrm{LiBO}_{2}$ & $\mathrm{Na}_{2} \mathrm{O}_{2}$ & BKV5 \\
Oxide & Fusion & Fusion & Fusion & Fusion & Powder \\
\hline $\mathrm{Al}_{2} \mathrm{O}_{3}$ & 10.4173 & 10.0066 & $\mathrm{ND}^{\mathrm{b}}$ & $\mathrm{ND}$ & 10.639 \\
$\mathrm{~B}_{2} \mathrm{O}_{3}$ & $\mathrm{ND}$ & 6.8206 & $\mathrm{ND}$ & $\mathrm{ND}$ & 3.7457 \\
$\mathrm{CaO}$ & 3.6192 & 4.1888 & $\mathrm{ND}$ & $\mathrm{ND}$ & 2.954 \\
$\mathrm{Cl}$ & $\mathrm{ND}$ & $\mathrm{ND}$ & $\mathrm{ND}$ & $\mathrm{ND}$ & 0.0518 \\
$\mathrm{Cr}_{2} \mathrm{O}_{3}$ & 0.0534 & 0.0541 & $\mathrm{ND}$ & $\mathrm{ND}$ & 0.0581 \\
$\mathrm{Fe}_{2} \mathrm{O}_{3}$ & 5.338 & 5.624 & $\mathrm{ND}$ & $\mathrm{ND}$ & 5.21 \\
$\mathrm{~K}_{2} \mathrm{O}$ & 2.3826 & 2.2782 & $\mathrm{ND}$ & $\mathrm{ND}$ & 1.46 \\
$\mathrm{MgO}^{\mathrm{O} O}$ & 1.5920 & 1.5065 & $\mathrm{ND}$ & $\mathrm{ND}$ & 1.59 \\
$\mathrm{Na}_{2} \mathrm{O}$ & 18.2233 & $\mathrm{ND}$ & $\mathrm{ND}$ & $\mathrm{ND}$ & 10.94 \\
$\mathrm{P}_{2} \mathrm{O}_{5}$ & 0.34 & 0.30 & $\mathrm{ND}$ & $\mathrm{ND}$ & 0.336 \\
$\mathrm{ReO}_{2}$ & $\mathrm{ND}$ & $\mathrm{ND}$ & $\mathrm{BLQ}$ & $\mathrm{BLQ}$ & $<0.0011$ \\
$\mathrm{SO}_{3}$ & 2.9764 & $\mathrm{BLQ}$ & $\mathrm{ND}$ & $\mathrm{ND}$ & 0.1526 \\
$\mathrm{SiO}_{2}$ & 51.24 & 52.78 & $\mathrm{ND}$ & $\mathrm{ND}$ & 54.68 \\
$\mathrm{TiO}_{2}$ & 0.962 & 0.972 & $\mathrm{ND}$ & $\mathrm{ND}$ & 0.8071 \\
$\mathrm{ZrO}_{2}$ & 7.4210 & 6.6113 & ND & ND & 6.99 \\
$\mathrm{Technique}^{\mathrm{c}}$ & $\mathrm{ICP}-\mathrm{OES}$ & $\mathrm{ICP}-\mathrm{OES}$ & $\mathrm{ICP}-\mathrm{MS}$ & ICP-MS & XRF \\
\hline
\end{tabular}

${ }^{\mathrm{a}}$ Results noted in italics were not used in calculations of the reported mean composition.

${ }^{\mathrm{b}} \mathrm{ND}=$ Not Determined

${ }^{c}$ BLQ=Below Limit of Quantification 


\subsection{Appendix B - Bulk Vitrified Glass SPFT Test Data}

Table B1. SPFT Temperature Sweep, Experimental Conditions, and Dissolution Rates. Data in parenthesis are near quantification limit.

Influent $\mathrm{Si}$

Flow Rate Time

$\mathrm{pH}$

Mass Sur. Area

B

B Rate

$\underline{\text { Sample ID }}$

$\stackrel{\mathrm{T}}{\left({ }^{\circ} \mathrm{C}\right)} \quad\left(\mathrm{m}^{3} / \mathrm{da}\right)$

Crucible Melt Test (ASCM-001)

Centerline

\begin{tabular}{cc}
\multicolumn{1}{c}{ Exp. \#1 } & \\
\cline { 1 - 1 } BKV1-1A & $8.82 \mathrm{E}+02$ \\
BKV1-1B & $8.82 \mathrm{E}+02$ \\
BKV1-1C & $8.82 \mathrm{E}+02$ \\
BKV1-1.2 & $8.82 \mathrm{E}+02$ \\
BKV1-1.4 & $8.82 \mathrm{E}+02$ \\
BKV1-1.6 & $8.82 \mathrm{E}+02$ \\
BKV1-1.8 & $8.82 \mathrm{E}+02$ \\
BKV1-1.11 & $8.82 \mathrm{E}+02$ \\
BKV1-1.16 & $8.82 \mathrm{E}+02$ \\
BKV1-1.19 & $8.82 \mathrm{E}+02$ \\
Exp. \#2 & \\
\cline { 1 - 1 } BKV1-2A & $1.61 \mathrm{E}+04$ \\
BKV1-2B & $1.61 \mathrm{E}+04$ \\
BKV1-2C & $1.61 \mathrm{E}+04$ \\
BKV1-2.2 & $1.61 \mathrm{E}+04$ \\
BKV1-2.4 & $1.61 \mathrm{E}+04$ \\
BKV1-2.6 & $1.61 \mathrm{E}+04$ \\
BKV1-2.8 & $1.61 \mathrm{E}+04$ \\
BKV1-2.11 & $1.61 \mathrm{E}+04$ \\
BKV1-2.16 & $1.61 \mathrm{E}+04$ \\
BKV1-2.19 & $1.61 \mathrm{E}+04$ \\
\cline { 1 - 1 } Exp. \#3 & \\
\cline { 1 - 1 } BKV1-3A & $3.21 \mathrm{E}+04$ \\
BKV1-3B & $3.21 \mathrm{E}+04$ \\
BKV1-3C & $3.21 \mathrm{E}+04$ \\
BKV1-3.2 & $3.21 \mathrm{E}+04$ \\
BKV1-3.4 & $3.21 \mathrm{E}+04$ \\
BKV1-3.6 & $3.21 \mathrm{E}+04$
\end{tabular}

$\begin{array}{cccccc}40 & - & - & 9.0 & - & - \\ 40 & - & - & 9.0 & - & - \\ 40 & - & - & 9.0 & - & - \\ 40 & 3.2 \mathrm{E}-05 & 2.89 & 9.0 & 1.004 & 2.01 \mathrm{E}-02 \\ 40 & 2.8 \mathrm{E}-05 & 5.07 & 9.0 & 1.004 & 2.01 \mathrm{E}-02 \\ 40 & 2.8 \mathrm{E}-05 & 7.02 & 9.0 & 1.003 & 2.01 \mathrm{E}-02 \\ 40 & 2.8 \mathrm{E}-05 & 9.13 & 9.0 & 1.003 & 2.00 \mathrm{E}-02 \\ 40 & 2.8 \mathrm{E}-05 & 12.11 & 9.0 & 1.003 & 2.00 \mathrm{E}-02 \\ 40 & 2.8 \mathrm{E}-05 & 18.89 & 9.0 & 1.002 & 2.00 \mathrm{E}-02 \\ 40 & 2.8 \mathrm{E}-05 & 25.05 & 9.0 & 1.002 & 2.00 \mathrm{E}-02\end{array}$

$<25$
$<25$
$<25$
62
96
108
111
112
111
110

-
-
-
$4.59 \mathrm{E}-03$
$7.74 \mathrm{E}-03$
$8.86 \mathrm{E}-03$
$9.21 \mathrm{E}-03$
$9.29 \mathrm{E}-03$
$9.01 \mathrm{E}-03$
$9.19 \mathrm{E}-03$

$<50$
$<50$
$<50$
162
287
324
338
346
341
338

-
-
-
$3.88 \mathrm{E}-03$
$7.22 \mathrm{E}-03$
$8.25 \mathrm{E}-03$
$8.68 \mathrm{E}-03$
$8.90 \mathrm{E}-03$
$8.62 \mathrm{E}-03$
$8.72 \mathrm{E}-03$

56
$<50$
$<50$
2,563
2,168
1,662
1,454
1,310
1,198
1,169

-
-
-
$2.30 \mathrm{E}-02$
$1.71 \mathrm{E}-02$
$1.28 \mathrm{E}-02$
$1.12 \mathrm{E}-02$
$1.00 \mathrm{E}-02$
$9.00 \mathrm{E}-03$
$8.97 \mathrm{E}-03$

\section{$<500$}

$<500$

$<500$

814

1,196

1,357

1,426

1,463

1,428

2.37E-03

$4.63 \mathrm{E}-03$

7.33E-09

$6.09 \mathrm{E}-03 \quad 7.99 \mathrm{E}-10$

$6.30 \mathrm{E}-03 \quad 2.86 \mathrm{E}-10$

$5.99 \mathrm{E}-03 \quad 0.00$

6.16E-03 $\quad 0.00$

$\begin{array}{cc}<25 & - \\ <25 & - \\ <25 & - \\ 48 & 2.57 \mathrm{E}-03 \\ 45 & 2.20 \mathrm{E}-03 \\ 44 & 2.05 \mathrm{E}-03 \\ 48 & 2.45 \mathrm{E}-03 \\ 50 & 2.62 \mathrm{E}-03 \\ 50 & 2.69 \mathrm{E}-03 \\ 49 & 2.56 \mathrm{E}-03\end{array}$

$<50$
$<50$
$<50$
109
127
125
131
114
139
131

-
-
-
$1.83 \mathrm{E}-03$
$2.34 \mathrm{E}-03$
$2.23 \mathrm{E}-03$
$2.45 \mathrm{E}-03$
$1.94 \mathrm{E}-03$
$2.65 \mathrm{E}-03$

55
55
55
2,618
1,730
1,229
1,029
877
722
665

-
-
-
$2.10 \mathrm{E}-02$
$1.35 \mathrm{E}-02$
$9.29 \mathrm{E}-03$
$7.82 \mathrm{E}-03$
$6.56 \mathrm{E}-03$
$5.24 \mathrm{E}-03$
$4.90 \mathrm{E}-03$

18,237

18,206

18,241

2.9E-05 2.89

$2.8 \mathrm{E}-05 \quad 5.07$

$2.8 \mathrm{E}-05 \quad 7.02$

$2.8 \mathrm{E}-05 \quad 9.13$

2.8E-05 18.89

$2.8 \mathrm{E}-05 \quad 25.05$

$1.009 \quad 2.02 \mathrm{E}-02$

$\begin{array}{cc}<25 & - \\ <25 & - \\ <25 & - \\ 68 & 3.70 \mathrm{E}-03 \\ 47 & 2.42 \mathrm{E}-03 \\ 35 & 1.13 \mathrm{E}-03\end{array}$

$<50$
$<50$
$<50$
108
109
91

$\begin{array}{cc}- & 52 \\ - & 61 \\ - & <50 \\ 1.42 \mathrm{E}-03 & 4,546 \\ 1.82 \mathrm{E}-03 & 3,124 \\ 1.26 \mathrm{E}-03 & 2,073\end{array}$

-
-
-
$2.91 \mathrm{E}-02$
$2.52 \mathrm{E}-02$
$1.64 \mathrm{E}-02$

18,624

18,462

18,614

18,638

18,630

18,523

$2.61 \mathrm{E}-03$

2.62E-03

$1.52 \mathrm{E}-03$

$2.55 \mathrm{E}-03$

$2.69 \mathrm{E}-03$

$2.60 \mathrm{E}-03$

$1.94 \mathrm{E}-03$

$7.35 \mathrm{E}-09$

$4.51 \mathrm{E}-09$

$2.89 \mathrm{E}-09$

2.14E-09

$1.57 \mathrm{E}-09$

1.02E-09

9.32E-10

36,464

36,248

36,350

$36,798 \quad 2.37 \mathrm{E}-03$

$1.01 \mathrm{E}-08$

$\begin{array}{lllll}2.9 \mathrm{E}-05 & 5.07 & 9.0 & 1.000 & 2.00 \mathrm{E}-02\end{array}$

$1.000 \quad 2.00 \mathrm{E}-02$ 
Table B1. SPFT Temperature Sweep, Experimental Conditions, and Dissolution Rates. Data in parenthesis are near quantification limit.

\begin{tabular}{|c|c|c|c|c|c|c|c|c|c|c|c|c|c|c|c|c|}
\hline & Influent $\mathrm{Si}$ & & Flow Rate & Time & $\mathrm{pH}$ & Mass & Sur. Area & B & B Rate & $\mathrm{Al}$ & Al Rate & $\mathrm{Na}$ & Na Rate & $\mathrm{Si}$ & Si Rate & IEX Rate \\
\hline$\underline{\text { Sample ID }}$ & $\underline{\left(\mu \mathrm{g} \mathrm{L}^{-1}\right)}$ & $\frac{\mathrm{T}}{\left({ }^{\circ} \mathrm{C}\right)}$ & $\underline{\left(\mathrm{m}^{3} / \mathrm{day}\right)}$ & $\underline{\text { (days) }}$ & $\underline{\left(23^{\circ} \mathrm{C}\right)}$ & $\underline{(\mathrm{g})}$ & $\underline{\left(\mathrm{m}^{2}\right)}$ & $\underline{\left(\mu g L^{-1}\right)}$ & $\underline{\left(\mathrm{g} \mathrm{m}^{-2} \mathrm{~d}^{-1}\right)}$ & $\underline{\left(\mu g \mathrm{~L}^{-1}\right)}$ & $\underline{\left(\mathrm{g} \mathrm{m}^{-2} \mathrm{~d}^{-1}\right)}$ & $\left.\underline{(\mu \mathrm{g} \mathrm{L}} \mathrm{L}^{-1}\right)$ & $\underline{\left(\mathrm{g} \mathrm{m}^{-2} \mathrm{~d}^{-1}\right)}$ & $\underline{\left(\mu \mathrm{g} \mathrm{L}^{-1}\right)}$ & $\underline{\left(\mathrm{g} \mathrm{m}^{-2} \mathrm{~d}^{-1}\right)}$ & $\underline{\left(\mathrm{mol} \mathrm{m} \mathrm{m}^{-2} \mathrm{~s}^{-1}\right)}$ \\
\hline BKV1-3.8 & $3.21 \mathrm{E}+04$ & $\frac{1}{40}$ & $2.9 \mathrm{E}-05$ & 9.13 & 9.0 & 0.999 & $2.00 \mathrm{E}-02$ & 33 & $8.44 \mathrm{E}-04$ & 85 & $1.07 \mathrm{E}-03$ & 1,644 & $1.30 \mathrm{E}-02$ & 36,433 & $5.31 \mathrm{E}-04$ & 4.84E-09 \\
\hline BKV1-3.11 & $3.21 \mathrm{E}+04$ & 40 & $2.9 \mathrm{E}-05$ & 12.11 & 9.0 & 0.999 & $2.00 \mathrm{E}-02$ & 31 & $6.71 \mathrm{E}-04$ & 79 & $8.96 \mathrm{E}-04$ & 1,331 & $1.04 \mathrm{E}-02$ & 36,233 & 0.00 & $3.90 \mathrm{E}-09$ \\
\hline BKV1-3.16 & $3.21 \mathrm{E}+04$ & 40 & $2.8 \mathrm{E}-05$ & 18.89 & 9.0 & 0.999 & $2.00 \mathrm{E}-02$ & 31 & $6.62 \mathrm{E}-04$ & 76 & $7.82 \mathrm{E}-04$ & 1,043 & $7.86 \mathrm{E}-03$ & 36,407 & $3.48 \mathrm{E}-04$ & $2.88 \mathrm{E}-09$ \\
\hline BKV1-3.19 & $3.21 \mathrm{E}+04$ & 40 & $2.9 \mathrm{E}-05$ & 25.05 & 9.0 & 0.999 & $2.00 \mathrm{E}-02$ & 29 & $3.98 \mathrm{E}-04$ & 76 & 7.89E-04 & 940 & $7.23 \mathrm{E}-03$ & 36,557 & $1.37 \mathrm{E}-03$ & $2.73 \mathrm{E}-09$ \\
\hline \multicolumn{17}{|l|}{ Exp. \#4 } \\
\hline BKV1-4A & $4.78 \mathrm{E}+04$ & 40 & - & - & 9.0 & - & - & $<25$ & - & $<50$ & - & $<50$ & - & 54,286 & - & - \\
\hline BKV1-4B & $4.78 \mathrm{E}+04$ & 40 & - & - & 9.0 & - & - & $<25$ & - & $<50$ & - & 50 & - & 53,965 & - & - \\
\hline BKV1-4C & $4.78 \mathrm{E}+04$ & 40 & - & - & 9.0 & - & - & $<25$ & - & $<50$ & - & 54 & - & 54,157 & - & - \\
\hline BKV1-4.2 & $4.78 \mathrm{E}+04$ & 40 & $3.3 \mathrm{E}-05$ & 2.89 & 9.0 & 2.003 & $3.18 \mathrm{E}-02$ & 74 & $3.90 \mathrm{E}-03$ & 110 & $1.34 \mathrm{E}-03$ & 5,043 & $2.98 \mathrm{E}-02$ & 52,562 & 0.00 & $1.03 \mathrm{E}-08$ \\
\hline BKV1-4.4 & $4.78 \mathrm{E}+04$ & 40 & $2.7 \mathrm{E}-05$ & 5.07 & 9.0 & 2.003 & $4.00 \mathrm{E}-02$ & 38 & $6.79 \mathrm{E}-04$ & 82 & $4.65 \mathrm{E}-04$ & 3,010 & $1.16 \mathrm{E}-02$ & 52,731 & 0.00 & $4.35 \mathrm{E}-09$ \\
\hline BKV1-4.6 & $4.78 \mathrm{E}+04$ & 40 & $2.8 \mathrm{E}-05$ & 7.02 & 9.0 & 2.003 & $4.00 \mathrm{E}-02$ & 26 & $3.01 \mathrm{E}-05$ & 69 & $2.79 \mathrm{E}-04$ & 2,077 & $8.04 \mathrm{E}-03$ & 52,424 & 0.00 & $3.20 \mathrm{E}-09$ \\
\hline BKV1-4.8 & $4.78 \mathrm{E}+04$ & 40 & $2.7 \mathrm{E}-05$ & 9.13 & 9.0 & 2.002 & $4.00 \mathrm{E}-02$ & (21) & 0.00 & 59 & $1.30 \mathrm{E}-04$ & 1,656 & $6.15 \mathrm{E}-03$ & 51,840 & 0.00 & $2.53 \mathrm{E}-09$ \\
\hline BKV1-4.11 & $4.78 \mathrm{E}+04$ & 40 & $2.8 \mathrm{E}-05$ & 12.11 & 9.0 & 2.002 & $4.00 \mathrm{E}-02$ & (19) & 0.00 & 55 & $7.31 \mathrm{E}-05$ & 1,372 & $5.27 \mathrm{E}-03$ & 52,083 & 0.00 & $2.23 \mathrm{E}-09$ \\
\hline BKV1-4.16 & $4.78 \mathrm{E}+04$ & 40 & $2.7 \mathrm{E}-05$ & 18.89 & 9.0 & 2.002 & $4.00 \mathrm{E}-02$ & (17) & 0.00 & (49) & 0.00 & 1,023 & $3.75 \mathrm{E}-03$ & 52,229 & 0.00 & $1.65 \mathrm{E}-09$ \\
\hline BKV1-4.19 & $4.78 \mathrm{E}+04$ & 40 & $2.7 \mathrm{E}-05$ & 25.05 & 9.0 & 2.002 & $4.00 \mathrm{E}-02$ & (16) & 0.00 & (44) & 0.00 & 846 & $3.06 \mathrm{E}-03$ & 51,677 & 0.00 & $1.40 \mathrm{E}-09$ \\
\hline BKV1-4.22 & $4.78 E+04$ & 40 & $1.1 \mathrm{E}-05$ & 37.04 & 9.0 & 2.002 & $4.00 \mathrm{E}-02$ & 60 & $7.44 \mathrm{E}-04$ & 70 & $1.17 \mathrm{E}-04$ & 1,731 & $2.66 \mathrm{E}-03$ & 53,544 & 0.00 & $7.63 \mathrm{E}-10$ \\
\hline BKV1-4.23 & $4.78 \mathrm{E}+04$ & 40 & $9.4 \mathrm{E}-06$ & 42.05 & 9.0 & 2.002 & 4.00E-02 & (46) & $3.78 \mathrm{E}-04$ & 74 & $1.22 \mathrm{E}-04$ & 2,196 & $2.87 \mathrm{E}-03$ & 54,526 & 4.30E-04 & $9.95 \mathrm{E}-10$ \\
\hline BKV1-4.24 & $4.78 \mathrm{E}+04$ & 40 & $9.3 \mathrm{E}-06$ & 45.13 & 9.0 & 2.002 & $4.00 \mathrm{E}-02$ & (47) & $3.92 \mathrm{E}-04$ & 95 & $2.28 \mathrm{E}-04$ & 2,367 & $3.08 \mathrm{E}-03$ & 54,851 & $7.82 \mathrm{E}-04$ & $1.07 \mathrm{E}-09$ \\
\hline BKV1-4.25 & $4.78 E+04$ & 40 & $8.9 \mathrm{E}-06$ & 47.10 & 9.0 & 2.001 & $4.00 \mathrm{E}-02$ & 51 & $4.36 \mathrm{E}-04$ & 128 & $3.74 \mathrm{E}-04$ & 2,357 & $2.94 \mathrm{E}-03$ & 56,131 & $2.09 \mathrm{E}-03$ & $9.99 \mathrm{E}-10$ \\
\hline BKV1-4.26 & $4.78 \mathrm{E}+04$ & 40 & $9.1 \mathrm{E}-06$ & 49.28 & 9.0 & 2.001 & $4.00 \mathrm{E}-02$ & 55 & 5.19E-04 & 149 & $4.87 \mathrm{E}-04$ & 2,251 & $2.87 \mathrm{E}-03$ & 56,346 & $2.37 \mathrm{E}-03$ & $9.39 \mathrm{E}-10$ \\
\hline BKV1-4.27 & $4.78 \mathrm{E}+04$ & 40 & $9.6 \mathrm{E}-06$ & 51.05 & 9.0 & 2.001 & $4.00 \mathrm{E}-02$ & 56 & $5.71 \mathrm{E}-04$ & 144 & $4.85 \mathrm{E}-04$ & 1,954 & $2.61 \mathrm{E}-03$ & 56,408 & $2.56 \mathrm{E}-03$ & $8.14 \mathrm{E}-10$ \\
\hline BKV1-4.28 & $4.78 E+04$ & 40 & $6.9 \mathrm{E}-06$ & 52.97 & 9.0 & 2.001 & $4.00 \mathrm{E}-02$ & 55 & $3.96 \mathrm{E}-04$ & 157 & $3.99 \mathrm{E}-04$ & 1,948 & $1.87 \mathrm{E}-03$ & 55,650 & $1.23 \mathrm{E}-03$ & $5.89 \mathrm{E}-10$ \\
\hline BKV1-4.29 & $4.78 \mathrm{E}+04$ & 40 & $9.4 \mathrm{E}-06$ & 53.93 & 9.0 & 2.001 & $4.00 \mathrm{E}-02$ & 53 & $5.08 \mathrm{E}-04$ & 142 & $4.68 \mathrm{E}-04$ & 1,707 & $2.23 \mathrm{E}-03$ & 54,750 & $6.81 \mathrm{E}-04$ & $6.89 \mathrm{E}-10$ \\
\hline BKV1-4.30 & $4.78 \mathrm{E}+04$ & 40 & $9.4 \mathrm{E}-06$ & 57.09 & 9.0 & 2.001 & $4.00 \mathrm{E}-02$ & 53 & $4.99 \mathrm{E}-04$ & 128 & $3.98 \mathrm{E}-04$ & 1,654 & $2.15 \mathrm{E}-03$ & 55,263 & $1.25 \mathrm{E}-03$ & $6.61 \mathrm{E}-10$ \\
\hline \multicolumn{17}{|l|}{ Exp. \#5 } \\
\hline BKV1-5A & $6.89 \mathrm{E}+04$ & 40 & - & - & 9.0 & - & - & (5) & - & $<50$ & - & 50 & - & 76,603 & - & - \\
\hline BKV1-5B & $6.89 \mathrm{E}+04$ & 40 & - & - & 9.0 & - & - & (1) & - & $<50$ & - & 54 & - & 80,919 & - & - \\
\hline BKV1-5C & $6.89 \mathrm{E}+04$ & 40 & - & - & 9.0 & - & - & ND & - & $<50$ & - & $<50$ & - & 76,697 & - & - \\
\hline BKV1-5.2 & $6.89 \mathrm{E}+04$ & 40 & $2.9 \mathrm{E}-05$ & 2.89 & 9.0 & 3.004 & $6.00 \mathrm{E}-02$ & 110 & $3.92 \mathrm{E}-03$ & 82 & $3.31 \mathrm{E}-04$ & 7,581 & $2.05 \mathrm{E}-02$ & 69,360 & 0.00 & $6.63 \mathrm{E}-09$ \\
\hline BKV1-5.4 & $6.89 \mathrm{E}+04$ & 40 & $2.9 \mathrm{E}-05$ & 5.07 & 9.0 & 3.004 & $6.00 \mathrm{E}-02$ & 46 & $1.57 \mathrm{E}-03$ & 57 & $7.23 \mathrm{E}-05$ & 4,396 & $1.18 \mathrm{E}-02$ & 65,072 & 0.00 & $4.08 \mathrm{E}-09$ \\
\hline BKV1-5.6 & $6.89 \mathrm{E}+04$ & 40 & $2.8 \mathrm{E}-05$ & 7.02 & 9.0 & 3.003 & $6.00 \mathrm{E}-02$ & 26 & $8.37 \mathrm{E}-04$ & 50 & 0.00 & 2,891 & 7.62E-03 & 64,432 & 0.00 & $2.71 \mathrm{E}-09$ \\
\hline BKV1-5.8 & $6.89 \mathrm{E}+04$ & 40 & $2.8 \mathrm{E}-05$ & 9.13 & 9.0 & 3.003 & $6.00 \mathrm{E}-02$ & (20) & $6.36 \mathrm{E}-04$ & (45) & 0.00 & 2,359 & $6.24 \mathrm{E}-03$ & 65,372 & 0.00 & $2.24 \mathrm{E}-09$ \\
\hline BKV1-5.19 & $6.89 \mathrm{E}+04$ & 40 & $2.8 \mathrm{E}-05$ & 25.05 & 9.0 & 3.003 & $6.00 \mathrm{E}-02$ & (11) & $3.05 \mathrm{E}-04$ & (31) & 0.00 & 1,374 & $3.47 \mathrm{E}-03$ & 68,546 & 0.00 & $1.27 \mathrm{E}-09$ \\
\hline
\end{tabular}


Table B1. SPFT Temperature Sweep, Experimental Conditions, and Dissolution Rates. Data in parenthesis are near quantification limit.

\begin{tabular}{|c|c|c|c|c|c|c|c|c|c|c|c|c|c|c|c|c|}
\hline & Influent $\mathrm{Si}$ & & Flow Rate & Time & $\mathrm{pH}$ & Mass & Sur. Area & B & B Rate & $\mathrm{Al}$ & Al Rate & $\mathrm{Na}$ & Na Rate & $\mathrm{Si}$ & Si Rate & IEX Rate \\
\hline$\underline{\text { Sample ID }}$ & $\left.\underline{(\mu \mathrm{g} \mathrm{L}} \mathrm{L}^{-1}\right)$ & $\frac{\mathrm{T}}{\left({ }^{\circ} \mathrm{C}\right)}$ & $\left(\mathrm{m}^{3} / \mathrm{day}\right)$ & $\underline{\text { (days) }}$ & $\underline{\left(23^{\circ} \mathrm{C}\right)}$ & $\underline{(\mathrm{g})}$ & $\left(\mathrm{m}^{2}\right)$ & $\underline{\left(\mu \mathrm{g} \mathrm{L}^{-1}\right)}$ & $\underline{\left(\mathrm{g} \mathrm{m}^{-2} \mathrm{~d}^{-1}\right)}$ & $\underline{\left(\mu \mathrm{g} \mathrm{L}^{-1}\right)}$ & $\underline{\left(\mathrm{g} \mathrm{m}^{-2} \mathrm{~d}^{-1}\right)}$ & $\underline{\left(\mu g \mathrm{~L}^{-1}\right)}$ & $\underline{\left(\mathrm{g} \mathrm{m}^{-2} \mathrm{~d}^{-1}\right)}$ & $\underline{\left(\mu g \mathrm{~L}^{-1}\right)}$ & $\underline{\left(\mathrm{g} \mathrm{m}^{-2} \mathrm{~d}^{-1}\right)}$ & $\left.\underline{(\mathrm{mol} \mathrm{m}} \mathrm{m}^{-2} \mathrm{~s}^{-1}\right)$ \\
\hline BKV1-5.21 & $6.89 \mathrm{E}+04$ & 40 & $9.3 \mathrm{E}-06$ & 32.85 & 9.0 & 3.003 & $6.00 \mathrm{E}-02$ & (24) & $2.54 \mathrm{E}-04$ & (47) & 0.00 & 2,471 & $2.13 \mathrm{E}-03$ & 70,115 & 0.00 & $7.50 \mathrm{E}-10$ \\
\hline BKV1-5.22 & $6.89 \mathrm{E}+04$ & 40 & $9.8 \mathrm{E}-06$ & 37.04 & 9.0 & 3.003 & $6.00 \mathrm{E}-02$ & (41) & $4.82 \mathrm{E}-04$ & 47 & 0.00 & 2,518 & $2.31 \mathrm{E}-03$ & 72,270 & 0.00 & $7.29 \mathrm{E}-10$ \\
\hline BKV1-5.23 & $6.89 \mathrm{E}+04$ & 40 & $9.5 \mathrm{E}-06$ & 42.05 & 9.0 & 3.003 & $6.00 \mathrm{E}-02$ & (29) & $3.15 \mathrm{E}-04$ & 42 & 0.00 & 3,029 & $2.68 \mathrm{E}-03$ & 72,601 & 0.00 & $9.45 \mathrm{E}-10$ \\
\hline BKV1-5.24 & $6.89 \mathrm{E}+04$ & 40 & $9.4 \mathrm{E}-06$ & 45.13 & 9.0 & 3.003 & $6.00 \mathrm{E}-02$ & (27) & $2.89 \mathrm{E}-04$ & 49 & 0.00 & 3,412 & $3.02 \mathrm{E}-03$ & 74,229 & 0.00 & $1.09 \mathrm{E}-09$ \\
\hline BKV1-5.25 & $6.89 \mathrm{E}+04$ & 40 & $8.7 \mathrm{E}-06$ & 47.10 & 9.0 & 3.003 & $6.00 \mathrm{E}-02$ & (27) & $2.67 \mathrm{E}-04$ & 58 & $2.56 \mathrm{E}-05$ & 3,133 & $2.55 \mathrm{E}-03$ & 75,150 & 0.00 & $9.11 \mathrm{E}-10$ \\
\hline BKV1-5.26 & $6.89 \mathrm{E}+04$ & 40 & $9.2 \mathrm{E}-06$ & 49.28 & 9.0 & 3.003 & $6.00 \mathrm{E}-02$ & (25) & $2.63 \mathrm{E}-04$ & 60 & $3.44 \mathrm{E}-05$ & 2,930 & $2.51 \mathrm{E}-03$ & 75,373 & 0.00 & $8.98 \mathrm{E}-10$ \\
\hline BKV1-5.28 & $6.89 \mathrm{E}+04$ & 40 & $9.3 \mathrm{E}-06$ & 52.97 & 9.0 & 3.003 & $6.00 \mathrm{E}-02$ & (23) & $2.46 \mathrm{E}-04$ & 62 & $4.11 \mathrm{E}-05$ & 2,613 & $2.27 \mathrm{E}-03$ & 74,431 & 0.00 & $8.06 \mathrm{E}-10$ \\
\hline BKV1-5.29 & $6.89 \mathrm{E}+04$ & 40 & $9.4 \mathrm{E}-06$ & 53.93 & 9.0 & 3.002 & $6.00 \mathrm{E}-02$ & (22) & $2.32 \mathrm{E}-04$ & 67 & $5.62 \mathrm{E}-05$ & 2,446 & $2.15 \mathrm{E}-03$ & 73,966 & 0.00 & $7.65 \mathrm{E}-10$ \\
\hline $\begin{array}{c}\text { BKV1-5.30 } \\
\text { Exp. \#6 }\end{array}$ & $6.89 \mathrm{E}+04$ & 40 & $9.4 \mathrm{E}-06$ & 57.09 & 9.0 & 3.002 & $6.00 \mathrm{E}-02$ & (22) & $2.35 \mathrm{E}-04$ & 60 & $3.53 \mathrm{E}-05$ & 2,482 & $2.17 \mathrm{E}-03$ & 75,896 & 0.00 & $7.74 \mathrm{E}-10$ \\
\hline BKV1-6A & $7.64 \mathrm{E}+04$ & 40 & - & - & 9.0 & - & - & (4) & - & $<25$ & - & 61 & - & 86,093 & - & - \\
\hline BKV1-6B & $7.64 \mathrm{E}+04$ & 40 & - & - & 9.0 & - & - & ND & - & $<25$ & - & 69 & - & 88,054 & - & - \\
\hline BKV1-6C & $7.64 \mathrm{E}+04$ & 40 & - & - & 9.0 & - & - & ND & - & $<25$ & - & 60 & - & 85,820 & - & - \\
\hline BKV1-6.2 & $7.64 \mathrm{E}+04$ & 40 & $3.0 \mathrm{E}-05$ & 2.89 & 9.0 & 3.009 & 4.17E-02 & 77 & $4.14 \mathrm{E}-03$ & (12) & 0.00 & 5,304 & $2.16 \mathrm{E}-02$ & 78,987 & 0.00 & $6.97 \mathrm{E}-09$ \\
\hline BKV1-6.6 & $7.64 \mathrm{E}+04$ & 40 & $2.8 \mathrm{E}-05$ & 7.02 & 9.0 & 3.008 & $6.01 \mathrm{E}-02$ & 30 & $1.00 \mathrm{E}-03$ & (12) & 0.00 & 3,180 & $8.32 \mathrm{E}-03$ & 71,733 & 0.00 & 2.92E-09 \\
\hline BKV1-6.8 & $7.64 \mathrm{E}+04$ & 40 & $2.8 \mathrm{E}-05$ & 9.13 & 9.0 & 3.008 & $6.01 \mathrm{E}-02$ & (19) & $6.23 \mathrm{E}-04$ & (9) & 0.00 & 2,456 & $6.44 \mathrm{E}-03$ & 71,550 & 0.00 & 2.32E-09 \\
\hline BKV1-6.11 & $7.64 \mathrm{E}+04$ & 40 & $2.8 \mathrm{E}-05$ & 12.11 & 9.0 & 3.008 & $6.01 \mathrm{E}-02$ & (16) & $4.80 \mathrm{E}-04$ & (16) & 0.00 & 1,927 & $5.01 \mathrm{E}-03$ & 68,929 & 0.00 & $1.81 \mathrm{E}-09$ \\
\hline BKV1-6.16 & $7.64 \mathrm{E}+04$ & 40 & 2.7E-05 & 18.89 & 9.0 & 3.008 & $6.01 \mathrm{E}-02$ & (12) & $3.54 \mathrm{E}-04$ & (12) & 0.00 & 1,416 & $3.52 \mathrm{E}-03$ & 66,837 & 0.00 & $1.27 \mathrm{E}-09$ \\
\hline BKV1-6.19 & $7.64 \mathrm{E}+04$ & 40 & $2.8 \mathrm{E}-05$ & 25.05 & 9.0 & 3.008 & $6.01 \mathrm{E}-02$ & (13) & $3.75 \mathrm{E}-04$ & (15) & 0.00 & 1,363 & $3.50 \mathrm{E}-03$ & 67,842 & 0.00 & $1.25 \mathrm{E}-09$ \\
\hline BKV1-6.21 & $7.64 \mathrm{E}+04$ & 40 & $9.3 \mathrm{E}-06$ & 32.85 & 9.0 & 3.008 & $6.01 \mathrm{E}-02$ & 27 & $2.96 \mathrm{E}-04$ & (27) & $6.34 \mathrm{E}-06$ & 2,369 & $2.04 \mathrm{E}-03$ & 69,070 & 0.00 & $6.98 \mathrm{E}-10$ \\
\hline BKV1-6.22 & $7.64 \mathrm{E}+04$ & 40 & $1.2 \mathrm{E}-05$ & 37.04 & 9.0 & 3.008 & $6.01 \mathrm{E}-02$ & (43) & $6.47 \mathrm{E}-04$ & 29 & $1.96 \mathrm{E}-05$ & 2,325 & $2.67 \mathrm{E}-03$ & 71,356 & 0.00 & 8.09E-10 \\
\hline BKV1-6.23 & $7.64 \mathrm{E}+04$ & 40 & $9.5 \mathrm{E}-06$ & 42.05 & 9.0 & 3.008 & $6.01 \mathrm{E}-02$ & (30) & $3.38 \mathrm{E}-04$ & 32 & $2.31 \mathrm{E}-05$ & 2,764 & $2.43 \mathrm{E}-03$ & 77,394 & 0.00 & $8.35 \mathrm{E}-10$ \\
\hline BKV1-6.24 & $7.64 \mathrm{E}+04$ & 40 & $9.4 \mathrm{E}-06$ & 45.13 & 9.0 & 3.008 & $6.01 \mathrm{E}-02$ & (28) & $3.05 \mathrm{E}-04$ & 32 & $2.22 \mathrm{E}-05$ & 3,279 & $2.87 \mathrm{E}-03$ & 83,921 & 0.00 & $1.02 \mathrm{E}-09$ \\
\hline BKV1-6.25 & $7.64 \mathrm{E}+04$ & 40 & $9.6 \mathrm{E}-06$ & 47.10 & 9.0 & 3.008 & $6.01 \mathrm{E}-02$ & (26) & $2.96 \mathrm{E}-04$ & 33 & $2.72 \mathrm{E}-05$ & 3,303 & $2.97 \mathrm{E}-03$ & 87,727 & $8.08 \mathrm{E}-04$ & $1.07 \mathrm{E}-09$ \\
\hline BKV1-6.26 & $7.64 \mathrm{E}+04$ & 40 & 9.3E-06 & 49.28 & 9.0 & 3.008 & $6.01 \mathrm{E}-02$ & (25) & $2.74 \mathrm{E}-04$ & 34 & $2.90 \mathrm{E}-05$ & 3,174 & $2.75 \mathrm{E}-03$ & 88,934 & $1.66 \mathrm{E}-03$ & $9.87 \mathrm{E}-10$ \\
\hline BKV1-6.27 & $7.64 \mathrm{E}+04$ & 40 & $9.5 \mathrm{E}-06$ & 51.05 & 9.0 & 3.008 & $6.01 \mathrm{E}-02$ & (24) & $2.58 \mathrm{E}-04$ & 37 & $4.11 \mathrm{E}-05$ & 2,921 & $2.58 \mathrm{E}-03$ & 89,736 & $2.28 \mathrm{E}-03$ & $9.25 \mathrm{E}-10$ \\
\hline BKV1-6.28 & $7.64 \mathrm{E}+04$ & 40 & 9.3E-06 & 52.97 & 9.0 & 3.007 & $6.01 \mathrm{E}-02$ & (22) & $2.30 \mathrm{E}-04$ & 36 & $3.63 \mathrm{E}-05$ & 2,754 & $2.39 \mathrm{E}-03$ & 91,004 & $3.18 \mathrm{E}-03$ & $8.61 \mathrm{E}-10$ \\
\hline BKV1-6.29 & $7.64 \mathrm{E}+04$ & 40 & $9.6 \mathrm{E}-06$ & 53.93 & 9.0 & 3.007 & $6.01 \mathrm{E}-02$ & (21) & $2.26 \mathrm{E}-04$ & 37 & $4.26 \mathrm{E}-05$ & 2,665 & $2.38 \mathrm{E}-03$ & 89,246 & $1.95 \mathrm{E}-03$ & $8.60 \mathrm{E}-10$ \\
\hline $\begin{array}{c}\text { BKV1-6.30 } \\
\text { Exp. \#7 }\end{array}$ & $7.64 \mathrm{E}+04$ & 40 & 9.4E-06 & 57.09 & 9.0 & 3.007 & $6.01 \mathrm{E}-02$ & (20) & $2.14 \mathrm{E}-04$ & 35 & $3.23 \mathrm{E}-05$ & 2,598 & $2.26 \mathrm{E}-03$ & 89,925 & $2.40 \mathrm{E}-03$ & $8.16 \mathrm{E}-10$ \\
\hline BKV1-7A & - & 40 & - & - & 7.0 & - & - & (13) & - & $<25$ & - & $<100$ & - & $<100$ & - & - \\
\hline BKV1-7.2 & - & 40 & $2.9 \mathrm{E}-05$ & 2.89 & 7.0 & 2.000 & $4.00 \mathrm{E}-02$ & 175 & $9.09 \mathrm{E}-03$ & (41) & $2.43 \mathrm{E}-04$ & 10,440 & $4.27 \mathrm{E}-02$ & 783 & $2.32 \mathrm{E}-03$ & $1.34 \mathrm{E}-08$ \\
\hline
\end{tabular}


Table B1. SPFT Temperature Sweep, Experimental Conditions, and Dissolution Rates. Data in parenthesis are near quantification limit.

\begin{tabular}{|c|c|c|c|c|c|c|c|c|c|c|c|c|c|c|c|c|}
\hline & Influent $\mathrm{Si}$ & & Flow Rate & Time & $\mathrm{pH}$ & Mass & Sur. Area & B & B Rate & $\mathrm{Al}$ & Al Rate & $\mathrm{Na}$ & Na Rate & $\mathrm{Si}$ & Si Rate & IEX Rate \\
\hline$\underline{\text { Sample ID }}$ & $\underline{\left(\mu g L^{-1}\right)}$ & $\frac{\mathrm{T}}{\left({ }^{\mathrm{o}} \mathrm{C}\right)}$ & $\underline{\left(\mathrm{m}^{3} / \mathrm{day}\right)}$ & $\underline{\text { (days) }}$ & $\underline{\left(23^{\circ} \mathrm{C}\right)}$ & $\underline{(\mathrm{g})}$ & $\underline{\left(\mathrm{m}^{2}\right)}$ & $\underline{\left(\mu g \mathrm{~L}^{-1}\right)}$ & $\underline{\left(\mathrm{g} \mathrm{m}^{-2} \mathrm{~d}^{-1}\right)}$ & $\underline{\left(\mu \mathrm{g} \mathrm{L}^{-1}\right)}$ & $\left(\mathrm{g} \mathrm{m}^{-2} \mathrm{~d}^{-1}\right)$ & $\underline{\left(\mu g \mathrm{~L}^{-1}\right)}$ & $\underline{\left(\mathrm{g} \mathrm{m}^{-2} \mathrm{~d}^{-1}\right)}$ & $\underline{\left(\mu \mathrm{L}^{-1}\right)}$ & $\left(\mathrm{g} \mathrm{m}^{-2} \mathrm{~d}^{-1}\right)$ & $\left.\left.\underline{(\mathrm{mol} \mathrm{m}} \mathrm{s}^{-2}\right)^{-1}\right)$ \\
\hline BKV1-7.4 & - & 40 & $2.8 \mathrm{E}-05$ & 5.07 & 7.0 & 1.999 & $4.00 \mathrm{E}-02$ & (74) & $3.48 \mathrm{E}-03$ & (28) & $5.37 \mathrm{E}-05$ & 4,993 & $1.99 \mathrm{E}-02$ & (490) & $1.31 \mathrm{E}-03$ & $6.56 \mathrm{E}-09$ \\
\hline BKV1-7.6 & - & 40 & $2.8 \mathrm{E}-05$ & 7.02 & 7.0 & 1.999 & $4.00 \mathrm{E}-02$ & (45) & $1.87 \mathrm{E}-03$ & (31) & $8.94 \mathrm{E}-05$ & 3,137 & $1.23 \mathrm{E}-02$ & $(341)$ & $8.04 \mathrm{E}-04$ & $4.16 \mathrm{E}-09$ \\
\hline BKV1-7.8 & - & 40 & $2.9 \mathrm{E}-05$ & 9.13 & 7.0 & 1.999 & $4.00 \mathrm{E}-02$ & (38) & $1.52 \mathrm{E}-03$ & (37) & $1.85 \mathrm{E}-04$ & 2,564 & $1.01 \mathrm{E}-02$ & (313) & $7.19 \mathrm{E}-04$ & $3.42 \mathrm{E}-09$ \\
\hline BKV1-7.11 & - & 40 & $2.7 \mathrm{E}-05$ & 12.11 & 7.0 & 1.999 & $3.99 \mathrm{E}-02$ & (28) & $8.96 \mathrm{E}-04$ & (32) & $1.05 \mathrm{E}-04$ & 1,915 & $7.00 \mathrm{E}-03$ & (253) & $4.84 \mathrm{E}-04$ & $2.44 \mathrm{E}-09$ \\
\hline BKV1-7.16 & - & 40 & $2.8 \mathrm{E}-05$ & 18.89 & 7.0 & 1.999 & $3.99 \mathrm{E}-02$ & (22) & $6.14 \mathrm{E}-04$ & (30) & $7.57 \mathrm{E}-05$ & 1,364 & $5.13 \mathrm{E}-03$ & (209) & $3.63 \mathrm{E}-04$ & $1.80 \mathrm{E}-09$ \\
\hline BKV1-7.19 & - & 40 & $2.9 \mathrm{E}-05$ & 25.05 & 7.0 & 1.999 & $3.99 \mathrm{E}-02$ & (23) & $6.93 \mathrm{E}-04$ & (43) & $2.73 \mathrm{E}-04$ & 1,189 & $4.48 \mathrm{E}-03$ & (219) & $4.02 \mathrm{E}-04$ & $1.51 \mathrm{E}-09$ \\
\hline BKV1-7.22 & - & 40 & $1.2 \mathrm{E}-05$ & 37.04 & 7.0 & 1.998 & $3.99 \mathrm{E}-02$ & (45) & $8.03 \mathrm{E}-04$ & 38 & $8.57 \mathrm{E}-05$ & 2,557 & $4.34 \mathrm{E}-03$ & (305) & $2.98 \mathrm{E}-04$ & $1.41 \mathrm{E}-09$ \\
\hline BKV1-7.23 & - & 40 & $9.6 \mathrm{E}-06$ & 42.05 & 7.0 & 1.998 & $3.99 \mathrm{E}-02$ & (37) & $4.86 \mathrm{E}-04$ & 33 & $4.38 \mathrm{E}-05$ & 2,080 & $2.71 \mathrm{E}-03$ & (251) & $1.70 \mathrm{E}-04$ & $8.88 \mathrm{E}-10$ \\
\hline BKV1-7.24 & - & 40 & $9.5 \mathrm{E}-06$ & 45.13 & 7.0 & 1.998 & $3.99 \mathrm{E}-02$ & (38) & $4.90 \mathrm{E}-04$ & 39 & $7.30 \mathrm{E}-05$ & 2,072 & $2.67 \mathrm{E}-03$ & (249) & $1.66 \mathrm{E}-04$ & $8.72 \mathrm{E}-10$ \\
\hline BKV1-7.25 & - & 40 & $8.6 \mathrm{E}-06$ & 47.10 & 7.0 & 1.998 & $3.99 \mathrm{E}-02$ & (37) & $4.38 \mathrm{E}-04$ & 42 & $8.05 \mathrm{E}-05$ & 2,211 & $2.60 \mathrm{E}-03$ & (254) & $1.56 \mathrm{E}-04$ & $8.64 \mathrm{E}-10$ \\
\hline BKV1-7.26 & - & 40 & $9.3 \mathrm{E}-06$ & 49.28 & 7.0 & 1.998 & $3.99 \mathrm{E}-02$ & (36) & $4.46 \mathrm{E}-04$ & 43 & $8.97 \mathrm{E}-05$ & 2,284 & $2.92 \mathrm{E}-03$ & (254) & $1.70 \mathrm{E}-04$ & $9.88 \mathrm{E}-10$ \\
\hline BKV1-7.27 & - & 40 & $9.7 \mathrm{E}-06$ & 51.05 & 7.0 & 1.998 & $3.99 \mathrm{E}-02$ & (33) & $4.13 \mathrm{E}-04$ & 44 & $9.96 \mathrm{E}-05$ & 2,350 & $3.12 \mathrm{E}-03$ & (247) & $1.68 \mathrm{E}-04$ & $1.08 \mathrm{E}-09$ \\
\hline BKV1-7.28 & - & 40 & 7.8E-06 & 52.97 & 7.0 & 1.998 & $3.99 \mathrm{E}-02$ & (28) & $2.65 \mathrm{E}-04$ & 40 & $6.42 \mathrm{E}-05$ & 2,160 & $2.29 \mathrm{E}-03$ & (225) & $1.15 \mathrm{E}-04$ & $8.08 \mathrm{E}-10$ \\
\hline BKV1-7.29 & - & 40 & $9.6 \mathrm{E}-06$ & 53.93 & 7.0 & 1.998 & $3.99 \mathrm{E}-02$ & (28) & $3.21 \mathrm{E}-04$ & 43 & $9.07 \mathrm{E}-05$ & 2,296 & $3.01 \mathrm{E}-03$ & (235) & $1.53 \mathrm{E}-04$ & $1.07 \mathrm{E}-09$ \\
\hline Exp. \#8 & & & & & & & & & & & & & & & & \\
\hline BKV1-8A & - & 40 & - & - & 8.0 & - & - & $<50$ & - & $<50$ & - & $<100$ & - & $<500$ & - & - \\
\hline BKV1-8B & - & 40 & - & - & 8.0 & - & - & $<50$ & - & $<50$ & - & $<100$ & - & $<500$ & - & - \\
\hline BKV1-8C & - & 40 & - & - & 8.0 & - & - & $<50$ & - & $<50$ & - & $<100$ & - & $<500$ & - & - \\
\hline BKV1-8.2 & - & 40 & $3.0 \mathrm{E}-05$ & 2.89 & 8.0 & 2.002 & $4.00 \mathrm{E}-02$ & 117 & $3.80 \mathrm{E}-03$ & 149 & $1.60 \mathrm{E}-03$ & 7,569 & $3.18 \mathrm{E}-02$ & 898 & $1.39 \mathrm{E}-03$ & $1.12 \mathrm{E}-08$ \\
\hline BKV1-8.4 & - & 40 & $2.9 \mathrm{E}-05$ & 5.07 & 8.0 & 2.001 & $4.00 \mathrm{E}-02$ & (58) & $4.45 \mathrm{E}-04$ & 138 & $1.38 \mathrm{E}-03$ & 4,651 & $1.88 \mathrm{E}-02$ & 653 & $5.22 \mathrm{E}-04$ & 7.33E-09 \\
\hline BKV1-8.22 & - & 40 & $1.2 \mathrm{E}-05$ & 37.04 & 8.0 & 2.000 & $4.00 \mathrm{E}-02$ & 87 & $8.62 \mathrm{E}-04$ & 197 & $9.60 \mathrm{E}-04$ & 2,454 & $4.06 \mathrm{E}-03$ & (942) & $6.28 \mathrm{E}-04$ & $1.28 \mathrm{E}-09$ \\
\hline BKV1-8.23 & - & 40 & $9.7 \mathrm{E}-06$ & 42.05 & 8.0 & 2.000 & $4.00 \mathrm{E}-02$ & 74 & $4.44 \mathrm{E}-04$ & 190 & $7.28 \mathrm{E}-04$ & 2,164 & $2.85 \mathrm{E}-03$ & (881) & $4.34 \mathrm{E}-04$ & $9.62 \mathrm{E}-10$ \\
\hline BKV1-8.24 & - & 40 & $9.6 \mathrm{E}-06$ & 45.13 & 8.0 & 2.000 & $4.00 \mathrm{E}-02$ & 72 & $4.12 \mathrm{E}-04$ & 214 & $8.49 \mathrm{E}-04$ & 2,050 & $2.67 \mathrm{E}-03$ & (933) & $4.87 \mathrm{E}-04$ & $9.01 \mathrm{E}-10$ \\
\hline BKV1-8.25 & - & 40 & $9.7 \mathrm{E}-06$ & 47.10 & 8.0 & 1.999 & $4.00 \mathrm{E}-02$ & 77 & $5.08 \mathrm{E}-04$ & 244 & $1.02 \mathrm{E}-03$ & 2,061 & $2.73 \mathrm{E}-03$ & 1,039 & $6.17 \mathrm{E}-04$ & $8.86 \mathrm{E}-10$ \\
\hline BKV1-8.26 & - & 40 & $9.4 \mathrm{E}-06$ & 49.28 & 8.0 & 1.999 & $4.00 \mathrm{E}-02$ & 78 & $5.03 \mathrm{E}-04$ & 246 & $9.91 \mathrm{E}-04$ & 1,981 & $2.52 \mathrm{E}-03$ & 1,053 & $6.10 \mathrm{E}-04$ & $8.06 \mathrm{E}-10$ \\
\hline BKV1-8.27 & - & 40 & $9.8 \mathrm{E}-06$ & 51.05 & 8.0 & 1.999 & $4.00 \mathrm{E}-02$ & 79 & $5.38 \mathrm{E}-04$ & 250 & $1.06 \mathrm{E}-03$ & 1,908 & $2.54 \mathrm{E}-03$ & 1,069 & $6.58 \mathrm{E}-04$ & $7.99 \mathrm{E}-10$ \\
\hline BKV1-8.28 & - & 40 & $9.0 \mathrm{E}-06$ & 52.97 & 8.0 & 1.999 & $3.99 \mathrm{E}-02$ & 83 & $5.70 \mathrm{E}-04$ & 265 & $1.05 \mathrm{E}-03$ & 1,996 & $2.45 \mathrm{E}-03$ & 1,142 & $6.83 \mathrm{E}-04$ & $7.52 \mathrm{E}-10$ \\
\hline BKV1-8.29 & - & 40 & $9.5 \mathrm{E}-06$ & 53.93 & 8.0 & 1.999 & $3.99 \mathrm{E}-02$ & 86 & $6.53 \mathrm{E}-04$ & 271 & $1.13 \mathrm{E}-03$ & 2,057 & $2.65 \mathrm{E}-03$ & 1,179 & $7.57 \mathrm{E}-04$ & $7.98 \mathrm{E}-10$ \\
\hline $\begin{array}{c}\text { BKV1-8.30 } \\
\text { Exp. \#9 }\end{array}$ & - & 40 & $9.4 \mathrm{E}-06$ & 57.09 & 8.0 & 1.999 & $3.99 \mathrm{E}-02$ & 84 & $6.13 \mathrm{E}-04$ & 263 & $1.08 \mathrm{E}-03$ & 1,941 & $2.47 \mathrm{E}-03$ & 1,175 & $7.46 \mathrm{E}-04$ & $7.42 \mathrm{E}-10$ \\
\hline BKV1-9A & - & 40 & - & - & 9.0 & - & - & $<50$ & - & $<50$ & - & $<100$ & - & 1,117 & - & - \\
\hline BKV1-9.2 & - & 40 & $3.0 \mathrm{E}-05$ & 2.89 & 9.0 & 2.000 & $4.00 \mathrm{E}-02$ & 107 & $3.27 \mathrm{E}-03$ & 282 & $3.72 \mathrm{E}-03$ & 6,001 & $2.51 \mathrm{E}-02$ & 1,282 & $1.44 \mathrm{E}-03$ & $8.72 \mathrm{E}-09$ \\
\hline
\end{tabular}


Table B1. SPFT Temperature Sweep, Experimental Conditions, and Dissolution Rates. Data in parenthesis are near quantification limit.

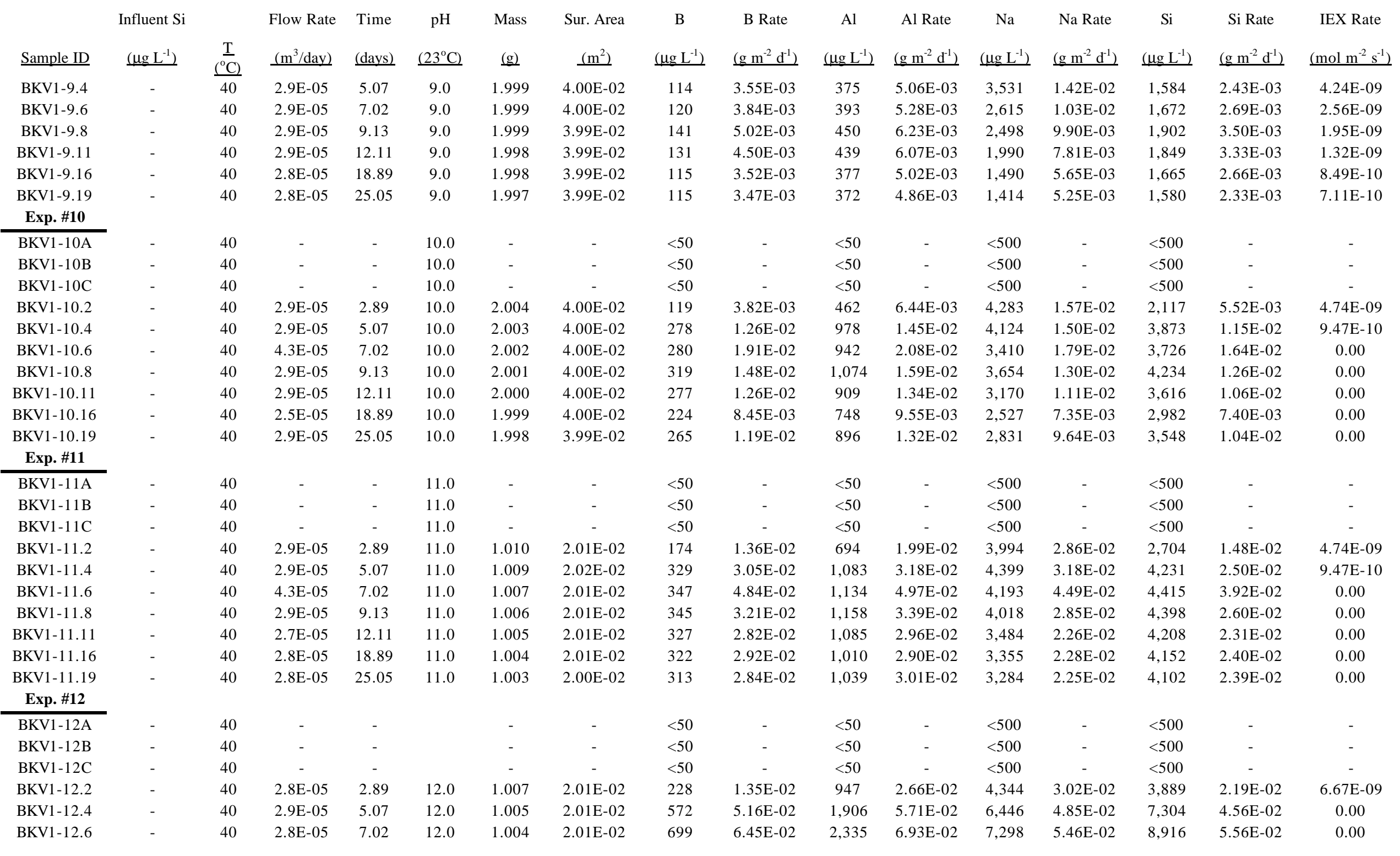


Table B1. SPFT Temperature Sweep, Experimental Conditions, and Dissolution Rates. Data in parenthesis are near quantification limit.

\begin{tabular}{|c|c|c|c|c|c|c|c|c|c|c|c|c|c|c|c|c|}
\hline$\underline{\text { Sample ID }}$ & $\begin{array}{l}\text { Influent Si } \\
\underline{\left(\mu \mathrm{g} \mathrm{L}^{-1}\right)}\end{array}$ & $\frac{\mathrm{T}}{\left({ }^{\circ} \mathrm{C}\right)}$ & $\begin{array}{l}\text { Flow Rate } \\
\underline{\left(\mathrm{m}^{3} / \mathrm{day}\right)}\end{array}$ & $\begin{array}{l}\text { Time } \\
\underline{\text { (days) }}\end{array}$ & $\begin{array}{c}\mathrm{pH} \\
\left(23^{\circ} \mathrm{C}\right) \\
\end{array}$ & $\begin{array}{l}\text { Mass } \\
\underline{(\mathrm{g})}\end{array}$ & $\begin{array}{l}\text { Sur. Area } \\
\qquad \underline{\left(\mathrm{m}^{2}\right)}\end{array}$ & $\begin{array}{c}\text { B } \\
\left(\mu \mathrm{g} \mathrm{L}^{-1}\right) \\
\end{array}$ & $\begin{array}{c}\text { B Rate } \\
\left(\mathrm{g} \mathrm{m}^{-2} \mathrm{~d}^{-1}\right) \\
\end{array}$ & $\begin{array}{c}\mathrm{Al} \\
\left.(\mu \mathrm{g} \mathrm{L})^{-1}\right) \\
\end{array}$ & $\begin{array}{l}\text { Al Rate } \\
\left(\mathrm{g} \mathrm{m}^{-2} \mathrm{~d}^{-1}\right) \\
\end{array}$ & $\begin{array}{c}\mathrm{Na} \\
\left(\mu g \mathrm{~L}^{-1}\right) \\
\end{array}$ & $\begin{array}{l}\text { Na Rate } \\
\left(\mathrm{g} \mathrm{m}^{-2} \mathrm{~d}^{-1}\right) \\
\end{array}$ & $\begin{array}{c}\mathrm{Si} \\
\left(\mu g \mathrm{~L}^{-1}\right) \\
\end{array}$ & $\begin{array}{l}\text { Si Rate } \\
\left(\mathrm{g} \mathrm{m}^{-2} \mathrm{~d}^{-1}\right) \\
\end{array}$ & $\begin{array}{c}\text { IEX Rate } \\
\left(\mathrm{mol} \mathrm{m}^{-2} \mathrm{~s}^{-1}\right) \\
\end{array}$ \\
\hline BKV1-12.8 & - & 40 & $2.9 \mathrm{E}-05$ & 9.13 & 12.0 & 1.001 & $2.00 \mathrm{E}-02$ & 803 & $7.68 \mathrm{E}-02$ & 2,721 & $8.21 \mathrm{E}-02$ & 7,830 & $5.97 \mathrm{E}-02$ & 10,350 & $6.60 \mathrm{E}-02$ & 0.00 \\
\hline BKV1-12.11 & - & 40 & 2.9E-05 & 12.11 & 12.0 & 0.999 & $2.00 \mathrm{E}-02$ & 683 & $6.41 \mathrm{E}-02$ & 2,260 & $6.84 \mathrm{E}-02$ & 6,937 & $5.28 \mathrm{E}-02$ & 8,792 & $5.60 \mathrm{E}-02$ & 0.00 \\
\hline BKV1-12.16 & - & 40 & $2.8 \mathrm{E}-05$ & 18.89 & 12.0 & 0.997 & $1.99 \mathrm{E}-02$ & 727 & $6.77 \mathrm{E}-02$ & 2,343 & $6.97 \mathrm{E}-02$ & 7,357 & $5.52 \mathrm{E}-02$ & 9,157 & $5.73 \mathrm{E}-02$ & 0.00 \\
\hline $\begin{array}{c}\text { BKV1-12.19 } \\
\text { Exp.\#13 }\end{array}$ & - & 40 & $2.9 \mathrm{E}-05$ & 25.05 & 12.0 & 0.994 & $1.99 \mathrm{E}-02$ & 729 & $6.97 \mathrm{E}-02$ & 2,412 & $7.36 \mathrm{E}-02$ & 7,232 & $5.56 \mathrm{E}-02$ & 9,286 & $5.97 \mathrm{E}-02$ & 0.00 \\
\hline BKV1-13.0 & - & 23 & - & - & 7.0 & - & - & (9) & - & 11 & - & 100 & - & $<100$ & - & - \\
\hline BKV1-13.1 & - & 23 & - & - & 7.0 & - & - & (5) & - & $<10$ & - & 126 & - & $<100$ & - & - \\
\hline BKV1-13.2 & - & 23 & - & - & 7.0 & - & - & (3) & - & $<10$ & - & $<100$ & - & $<100$ & - & - \\
\hline BKV1-13.3 & - & 23 & $2.1 \mathrm{E}-05$ & 4.13 & 7.0 & 3.001 & $6.00 \mathrm{E}-02$ & 101 & $2.56 \mathrm{E}-03$ & 40 & $2.25 \mathrm{E}-04$ & 7,408 & $1.45 \mathrm{E}-02$ & $(480)$ & $6.22 \mathrm{E}-04$ & 4.78E-09 \\
\hline BKV1-13.5 & - & 23 & $2.0 \mathrm{E}-05$ & 6.04 & 7.0 & 3.001 & $6.00 \mathrm{E}-02$ & 79 & $1.90 \mathrm{E}-03$ & 22 & $8.53 \mathrm{E}-05$ & 6,277 & $1.19 \mathrm{E}-02$ & $(424)$ & $5.14 \mathrm{E}-04$ & $3.99 \mathrm{E}-09$ \\
\hline BKV1-13.7 & - & 23 & $2.1 \mathrm{E}-05$ & 8.09 & 7.0 & 3.000 & $6.00 \mathrm{E}-02$ & (43) & $9.85 \mathrm{E}-04$ & 23 & $9.09 \mathrm{E}-05$ & 3,752 & $7.21 \mathrm{E}-03$ & (308) & $3.38 \mathrm{E}-04$ & 2.49E-09 \\
\hline BKV1-13.9 & - & 23 & $2.1 \mathrm{E}-05$ & 10.15 & 7.0 & 3.000 & $6.00 \mathrm{E}-02$ & (29) & $6.36 \mathrm{E}-04$ & 22 & $9.14 \mathrm{E}-05$ & 2,687 & $5.23 \mathrm{E}-03$ & (252) & $2.54 \mathrm{E}-04$ & $1.84 \mathrm{E}-09$ \\
\hline BKV1-13.12 & - & 23 & $2.2 \mathrm{E}-05$ & 15.07 & 7.0 & 3.000 & $6.00 \mathrm{E}-02$ & (19) & $3.90 \mathrm{E}-04$ & 24 & $1.10 \mathrm{E}-04$ & 1,807 & $3.62 \mathrm{E}-03$ & (205) & $1.85 \mathrm{E}-04$ & $1.29 \mathrm{E}-09$ \\
\hline BKV1-13.17 & - & 23 & $2.2 \mathrm{E}-05$ & 21.13 & 7.0 & 3.000 & $6.00 \mathrm{E}-02$ & (12) & $1.82 \mathrm{E}-04$ & 20 & 7.37E-05 & 1,156 & $2.18 \mathrm{E}-03$ & (159) & $1.01 \mathrm{E}-04$ & $8.00 \mathrm{E}-10$ \\
\hline BKV1-13.22 & - & 23 & $2.2 \mathrm{E}-05$ & 27.06 & 7.0 & 3.000 & $6.00 \mathrm{E}-02$ & (14) & $2.27 \mathrm{E}-04$ & 11 & $2.63 \mathrm{E}-06$ & 1,435 & $2.77 \mathrm{E}-03$ & $(312)$ & $3.64 \mathrm{E}-04$ & $1.01 \mathrm{E}-09$ \\
\hline BKV1-13.25 & - & 23 & $2.0 \mathrm{E}-05$ & 29.97 & 7.0 & 3.000 & $6.00 \mathrm{E}-02$ & (11) & $1.37 \mathrm{E}-04$ & 17 & 4.64E-05 & 1,252 & $2.15 \mathrm{E}-03$ & (159) & $9.10 \mathrm{E}-05$ & $8.02 \mathrm{E}-10$ \\
\hline BKV1-13.26 & - & 23 & $2.1 \mathrm{E}-05$ & 31.01 & 7.0 & 3.000 & $6.00 \mathrm{E}-02$ & (33) & $7.23 \mathrm{E}-04$ & (15) & $3.53 \mathrm{E}-05$ & 1,254 & $2.25 \mathrm{E}-03$ & (133) & $5.26 \mathrm{E}-05$ & $6.08 \mathrm{E}-10$ \\
\hline BKV1-13.27 & - & 23 & $2.0 \mathrm{E}-05$ & 32.21 & 7.0 & 3.000 & $6.00 \mathrm{E}-02$ & (24) & $4.90 \mathrm{E}-04$ & (14) & $2.72 \mathrm{E}-05$ & 1,184 & $2.09 \mathrm{E}-03$ & (127) & $4.38 \mathrm{E}-05$ & $6.41 \mathrm{E}-10$ \\
\hline BKV1-13.28 & - & 23 & $2.0 \mathrm{E}-05$ & 34.10 & 7.0 & 3.000 & $6.00 \mathrm{E}-02$ & (21) & $3.94 \mathrm{E}-04$ & (14) & $2.76 \mathrm{E}-05$ & 1,216 & $2.11 \mathrm{E}-03$ & (130) & $4.75 \mathrm{E}-05$ & $6.86 \mathrm{E}-10$ \\
\hline BKV1-13.29 & - & 23 & $2.1 \mathrm{E}-05$ & 35.11 & 7.0 & 3.000 & $6.00 \mathrm{E}-02$ & (20) & $3.68 \mathrm{E}-04$ & (15) & $3.14 \mathrm{E}-05$ & 1,209 & $2.15 \mathrm{E}-03$ & (132) & $5.08 \mathrm{E}-05$ & $7.13 \mathrm{E}-10$ \\
\hline BKV1-13.30 & - & 23 & $2.0 \mathrm{E}-05$ & 36.09 & 7.0 & 3.000 & $6.00 \mathrm{E}-02$ & (18) & $3.30 \mathrm{E}-04$ & (15) & $3.25 \mathrm{E}-05$ & 1,239 & $2.17 \mathrm{E}-03$ & (130) & $4.70 \mathrm{E}-05$ & $7.37 \mathrm{E}-10$ \\
\hline BKV1-13.31 & - & 23 & $2.0 \mathrm{E}-05$ & 37.16 & 7.0 & 3.000 & $6.00 \mathrm{E}-02$ & (17) & $2.88 \mathrm{E}-04$ & (15) & $3.01 \mathrm{E}-05$ & 1,156 & $2.00 \mathrm{E}-03$ & (123) & $3.61 \mathrm{E}-05$ & $6.84 \mathrm{E}-10$ \\
\hline BKV1-13.32 & - & 23 & $2.1 \mathrm{E}-05$ & 38.22 & 7.0 & 3.000 & $6.00 \mathrm{E}-02$ & (16) & $2.77 \mathrm{E}-04$ & (19) & $6.36 \mathrm{E}-05$ & 1,085 & $1.95 \mathrm{E}-03$ & (123) & $3.78 \mathrm{E}-05$ & $6.67 \mathrm{E}-10$ \\
\hline BKV1-13.33 & - & 23 & $2.1 \mathrm{E}-05$ & 39.15 & 7.0 & 3.000 & $6.00 \mathrm{E}-02$ & (15) & $2.53 \mathrm{E}-04$ & (19) & $6.65 \mathrm{E}-05$ & 1,065 & $1.87 \mathrm{E}-03$ & (122) & $3.52 \mathrm{E}-05$ & $6.47 \mathrm{E}-10$ \\
\hline BKV1-13.34 & - & 23 & $2.0 \mathrm{E}-05$ & 40.10 & 7.0 & 3.000 & $5.99 \mathrm{E}-02$ & (15) & $2.43 \mathrm{E}-04$ & (22) & $8.66 \mathrm{E}-05$ & 1,056 & $1.83 \mathrm{E}-03$ & (124) & $3.87 \mathrm{E}-05$ & $6.34 \mathrm{E}-10$ \\
\hline BKV1-13.35 & - & 23 & $2.0 \mathrm{E}-05$ & 41.32 & 7.0 & 3.000 & $5.99 \mathrm{E}-02$ & (15) & $2.46 \mathrm{E}-04$ & (22) & $8.24 \mathrm{E}-05$ & 1,024 & $1.76 \mathrm{E}-03$ & (131) & $4.85 \mathrm{E}-05$ & $6.04 \mathrm{E}-10$ \\
\hline BKV1-13.36 & - & 23 & $2.1 \mathrm{E}-05$ & 42.20 & 7.0 & 3.000 & $5.99 \mathrm{E}-02$ & (31) & $6.75 \mathrm{E}-04$ & (22) & 8.59E-05 & 950 & $1.66 \mathrm{E}-03$ & (116) & $2.62 \mathrm{E}-05$ & $3.94 \mathrm{E}-10$ \\
\hline BKV1-13.37 & - & 23 & $2.0 \mathrm{E}-05$ & 43.10 & 7.0 & 2.999 & $5.99 \mathrm{E}-02$ & (23) & $4.44 \mathrm{E}-04$ & (21) & $8.04 \mathrm{E}-05$ & 898 & $1.53 \mathrm{E}-03$ & (112) & $1.91 \mathrm{E}-05$ & $4.35 \mathrm{E}-10$ \\
\hline BKV1-13.38 & - & 23 & $2.1 \mathrm{E}-05$ & 44.09 & 7.0 & 2.999 & $5.99 \mathrm{E}-02$ & (18) & $3.33 \mathrm{E}-04$ & (23) & $9.41 \mathrm{E}-05$ & 871 & $1.56 \mathrm{E}-03$ & (108) & $1.39 \mathrm{E}-05$ & $4.91 \mathrm{E}-10$ \\
\hline BKV1-13.39 & - & 23 & $2.1 \mathrm{E}-05$ & 45.01 & 7.0 & 2.999 & $5.99 \mathrm{E}-02$ & (17) & $2.93 \mathrm{E}-04$ & (22) & $8.56 \mathrm{E}-05$ & 896 & $1.55 \mathrm{E}-03$ & (111) & $1.76 \mathrm{E}-05$ & $5.04 \mathrm{E}-10$ \\
\hline BKV1-13.40 & - & 23 & $2.1 \mathrm{E}-05$ & 47.97 & 7.0 & 2.999 & $5.99 \mathrm{E}-02$ & (17) & $3.01 \mathrm{E}-04$ & (21) & $8.01 \mathrm{E}-05$ & 897 & $1.61 \mathrm{E}-03$ & (132) & $5.35 \mathrm{E}-05$ & $5.23 \mathrm{E}-10$ \\
\hline
\end{tabular}

Exp. \#14 
Table B1. SPFT Temperature Sweep, Experimental Conditions, and Dissolution Rates. Data in parenthesis are near quantification limit.

\begin{tabular}{|c|c|c|c|c|c|c|c|c|c|c|c|c|c|c|c|c|}
\hline & Influent $\mathrm{Si}$ & & Flow Rate & Time & $\mathrm{pH}$ & Mass & Sur. Area & B & B Rate & $\mathrm{Al}$ & Al Rate & $\mathrm{Na}$ & Na Rate & $\mathrm{Si}$ & Si Rate & IEX Rate \\
\hline$\underline{\text { Sample ID }}$ & $\underline{\left(\mu g \mathrm{~L}^{-1}\right)}$ & $\frac{\mathrm{T}}{\left({ }^{\circ} \mathrm{C}\right)}$ & $\underline{\left(\mathrm{m}^{3} / \mathrm{day}\right)}$ & $\underline{\text { (days) }}$ & $\underline{\left(23^{\circ} \mathrm{C}\right)}$ & (g) & $\underline{\left(\mathrm{m}^{2}\right)}$ & $\underline{\left(\mu g \mathrm{~L}^{-1}\right)}$ & $\underline{\left(\mathrm{g} \mathrm{m}^{-2} \mathrm{~d}^{-1}\right)}$ & $\underline{\left(\mu \mathrm{g} \mathrm{L} \mathrm{L}^{-1}\right)}$ & $\underline{\left(\mathrm{g} \mathrm{m}^{-2} \mathrm{~d}^{-1}\right)}$ & $\underline{\left(\mu \mathrm{L}^{-1}\right)}$ & $\underline{\left(\mathrm{g} \mathrm{m}^{-2} \mathrm{~d}^{-1}\right)}$ & $\underline{\left(\mu \mathrm{g} \mathrm{L}^{-1}\right)}$ & $\left(\mathrm{g} \mathrm{m}^{-2} \mathrm{~d}^{-1}\right)$ & $\left.\underline{(\mathrm{mol} \mathrm{m}} \mathrm{m}^{-2} \mathrm{~s}^{-1}\right)$ \\
\hline BKV1-14.3 & - & 23 & $2.1 \mathrm{E}-05$ & 4.13 & 8.0 & 3.010 & $6.02 \mathrm{E}-02$ & 66 & $4.12 \mathrm{E}-04$ & 65 & $3.37 \mathrm{E}-04$ & 5,353 & $1.03 \mathrm{E}-02$ & (395) & $4.73 \mathrm{E}-04$ & $3.93 \mathrm{E}-09$ \\
\hline BKV1-14.5 & - & 23 & $2.0 \mathrm{E}-05$ & 6.04 & 8.0 & 3.010 & $6.02 \mathrm{E}-02$ & 51 & $3.27 \mathrm{E}-05$ & 85 & $4.68 \mathrm{E}-04$ & 4,522 & 8.38E-03 & $(450)$ & $5.45 \mathrm{E}-04$ & 3.33E-09 \\
\hline BKV1-14.29 & - & 23 & $2.1 \mathrm{E}-05$ & 35.11 & 8.0 & 3.009 & $6.01 \mathrm{E}-02$ & 50 & $1.14 \mathrm{E}-05$ & 49 & $2.23 \mathrm{E}-04$ & 947 & $1.66 \mathrm{E}-03$ & (222) & $1.96 \mathrm{E}-04$ & $6.57 \mathrm{E}-10$ \\
\hline BKV1-14.30 & - & 23 & $2.0 \mathrm{E}-05$ & 36.09 & 8.0 & 3.009 & $6.01 \mathrm{E}-02$ & 51 & $2.32 \mathrm{E}-05$ & 50 & $2.20 \mathrm{E}-04$ & 947 & $1.60 \mathrm{E}-03$ & $(220)$ & $1.87 \mathrm{E}-04$ & $6.31 \mathrm{E}-10$ \\
\hline BKV1-14.31 & - & 23 & $2.0 \mathrm{E}-05$ & 37.16 & 8.0 & 3.009 & $6.01 \mathrm{E}-02$ & 52 & $5.20 \mathrm{E}-05$ & 50 & $2.26 \mathrm{E}-04$ & 940 & $1.62 \mathrm{E}-03$ & (228) & $2.02 \mathrm{E}-04$ & $6.25 \mathrm{E}-10$ \\
\hline BKV1-14.32 & - & 23 & $2.0 \mathrm{E}-05$ & 38.22 & 8.0 & 3.009 & $6.01 \mathrm{E}-02$ & 50 & $9.52 \mathrm{E}-06$ & 50 & $2.23 \mathrm{E}-04$ & 793 & $1.35 \mathrm{E}-03$ & (222) & $1.96 \mathrm{E}-04$ & $5.33 \mathrm{E}-10$ \\
\hline BKV1-14.34 & - & 23 & $2.0 \mathrm{E}-05$ & 40.10 & 8.0 & 3.008 & $6.01 \mathrm{E}-02$ & 63 & $3.26 \mathrm{E}-04$ & 62 & $3.08 \mathrm{E}-04$ & 863 & $1.44 \mathrm{E}-03$ & (239) & $2.16 \mathrm{E}-04$ & $4.45 \mathrm{E}-10$ \\
\hline BKV1-14.35 & - & 23 & $2.0 \mathrm{E}-05$ & 41.32 & 8.0 & 3.008 & $6.01 \mathrm{E}-02$ & 65 & $3.95 \mathrm{E}-04$ & 63 & $3.15 \mathrm{E}-04$ & 730 & $1.20 \mathrm{E}-03$ & (252) & $2.40 \mathrm{E}-04$ & $3.23 \mathrm{E}-10$ \\
\hline BKV1-14.36 & - & 23 & $2.1 \mathrm{E}-05$ & 42.20 & 8.0 & 3.008 & $6.01 \mathrm{E}-02$ & 67 & 4.36E-04 & 65 & 3.39E-04 & 819 & $1.41 \mathrm{E}-03$ & $(245)$ & $2.33 \mathrm{E}-04$ & $3.87 \mathrm{E}-10$ \\
\hline BKV1-14.37 & - & 23 & $2.0 \mathrm{E}-05$ & 43.10 & 8.0 & 3.008 & $6.01 \mathrm{E}-02$ & 64 & $3.52 \mathrm{E}-04$ & 63 & $3.16 \mathrm{E}-04$ & 798 & $1.34 \mathrm{E}-03$ & (246) & $2.30 \mathrm{E}-04$ & $3.95 \mathrm{E}-10$ \\
\hline BKV1-14.38 & - & 23 & $2.1 \mathrm{E}-05$ & 44.09 & 8.0 & 3.008 & $6.01 \mathrm{E}-02$ & 69 & $5.28 \mathrm{E}-04$ & 68 & $3.77 \mathrm{E}-04$ & 756 & $1.33 \mathrm{E}-03$ & (269) & $2.82 \mathrm{E}-04$ & $3.22 \mathrm{E}-10$ \\
\hline BKV1-14.39 & - & 23 & $2.1 \mathrm{E}-05$ & 45.01 & 8.0 & 3.008 & $6.01 \mathrm{E}-02$ & 61 & $2.95 \mathrm{E}-04$ & 60 & $3.02 \mathrm{E}-04$ & 707 & $1.20 \mathrm{E}-03$ & (239) & $2.27 \mathrm{E}-04$ & $3.62 \mathrm{E}-10$ \\
\hline BKV1-14.40 & - & 23 & $2.1 \mathrm{E}-05$ & 47.97 & 8.0 & 3.007 & $6.01 \mathrm{E}-02$ & 62 & $3.38 \mathrm{E}-04$ & 62 & $3.25 \mathrm{E}-04$ & 738 & $1.30 \mathrm{E}-03$ & (273) & $2.89 \mathrm{E}-04$ & $3.84 \mathrm{E}-10$ \\
\hline Exp. \#15 & & & & & & & & & & & & & & & & \\
\hline BKV1-15.1 & - & 23 & - & - & 9.0 & - & - & $<50$ & - & $<10$ & - & $<100$ & - & $<500$ & - & - \\
\hline BKV1-15.2 & - & 23 & - & - & 9.0 & - & - & $<50$ & - & 12 & - & $<100$ & - & $<500$ & - & - \\
\hline BKV1-15.3 & - & 23 & $2.0 \mathrm{E}-05$ & 4.13 & 9.0 & 2.006 & $3.18 \mathrm{E}-02$ & (46) & 0.00 & 111 & $1.37 \mathrm{E}-03$ & 2,803 & $9.77 \mathrm{E}-03$ & (477) & 0.00 & $3.97 \mathrm{E}-09$ \\
\hline BKV1-15.5 & - & 23 & $2.0 \mathrm{E}-05$ & 6.04 & 9.0 & 2.006 & $4.01 \mathrm{E}-02$ & 50 & $2.89 \mathrm{E}-06$ & 202 & $2.08 \mathrm{E}-03$ & 2,395 & $6.60 \mathrm{E}-03$ & 808 & $7.29 \mathrm{E}-04$ & 2.63E-09 \\
\hline BKV1-15.7 & - & 23 & $2.1 \mathrm{E}-05$ & 8.09 & 9.0 & 2.006 & $4.01 \mathrm{E}-02$ & 58 & $3.05 \mathrm{E}-04$ & 230 & $2.45 \mathrm{E}-03$ & 1,592 & 4.43E-03 & 925 & $1.04 \mathrm{E}-03$ & $1.65 \mathrm{E}-09$ \\
\hline BKV1-15.9 & - & 23 & $2.1 \mathrm{E}-05$ & 10.15 & 9.0 & 2.005 & $4.01 \mathrm{E}-02$ & 66 & $6.36 \mathrm{E}-04$ & 238 & $2.56 \mathrm{E}-03$ & 1,362 & $3.77 \mathrm{E}-03$ & 992 & $1.21 \mathrm{E}-03$ & $1.25 \mathrm{E}-09$ \\
\hline BKV1-15.12 & - & 23 & $2.1 \mathrm{E}-05$ & 15.07 & 9.0 & 2.005 & $4.01 \mathrm{E}-02$ & 71 & $8.27 \mathrm{E}-04$ & 241 & $2.58 \mathrm{E}-03$ & 1,314 & $3.60 \mathrm{E}-03$ & 1,003 & $1.23 \mathrm{E}-03$ & $1.11 \mathrm{E}-09$ \\
\hline BKV1-15.17 & - & 23 & $2.1 \mathrm{E}-05$ & 21.13 & 9.0 & 2.005 & $4.01 \mathrm{E}-02$ & 64 & $5.43 \mathrm{E}-04$ & 219 & $2.36 \mathrm{E}-03$ & 869 & $2.30 \mathrm{E}-03$ & 899 & $9.83 \mathrm{E}-04$ & $7.03 \mathrm{E}-10$ \\
\hline BKV1-15.22 & - & 23 & $2.1 \mathrm{E}-05$ & 27.06 & 9.0 & 2.005 & $4.01 \mathrm{E}-02$ & 73 & $9.31 \mathrm{E}-04$ & 250 & $2.71 \mathrm{E}-03$ & 744 & $1.93 \mathrm{E}-03$ & 1,048 & $1.35 \mathrm{E}-03$ & $3.99 \mathrm{E}-10$ \\
\hline BKV1-15.24 & - & 23 & $2.3 \mathrm{E}-05$ & 29.08 & 9.0 & 2.005 & $4.01 \mathrm{E}-02$ & 73 & $9.80 \mathrm{E}-04$ & 214 & $2.48 \mathrm{E}-03$ & 726 & $2.02 \mathrm{E}-03$ & 1,023 & $1.39 \mathrm{E}-03$ & $4.17 \mathrm{E}-10$ \\
\hline BKV1-15.25 & - & 23 & $2.0 \mathrm{E}-05$ & 29.97 & 9.0 & 2.004 & $4.01 \mathrm{E}-02$ & 73 & $8.47 \mathrm{E}-04$ & 245 & $2.47 \mathrm{E}-03$ & 762 & $1.85 \mathrm{E}-03$ & 1,034 & $1.23 \mathrm{E}-03$ & $4.01 \mathrm{E}-10$ \\
\hline Exp. \#16 & & & & & & & & & & & & & & & & \\
\hline BKV1-16.0 & - & 23 & - & - & 10.0 & - & - & $<50$ & - & 10 & - & $<100$ & - & $<500$ & - & - \\
\hline BKV1-16.1 & - & 23 & - & - & 10.0 & - & - & $<50$ & - & 11 & - & $<100$ & - & $<500$ & - & - \\
\hline BKV1-16.2 & - & 23 & - & - & 10.0 & - & - & $<50$ & - & 13 & - & $<100$ & - & $<500$ & - & - \\
\hline BKV1-16.3 & - & 23 & $1.9 \mathrm{E}-05$ & 4.13 & 10.0 & 2.001 & $4.00 \mathrm{E}-02$ & 171 & $4.40 \mathrm{E}-03$ & 659 & $6.62 \mathrm{E}-03$ & 4,065 & $1.07 \mathrm{E}-02$ & 2,524 & $4.52 \mathrm{E}-03$ & $2.54 \mathrm{E}-09$ \\
\hline BKV1-16.5 & - & 23 & $2.0 \mathrm{E}-05$ & 6.04 & 10.0 & 2.000 & $4.00 \mathrm{E}-02$ & 141 & $3.53 \mathrm{E}-03$ & 573 & $6.11 \mathrm{E}-03$ & 2,761 & 7.67E-03 & 2,293 & $4.25 \mathrm{E}-03$ & $1.65 \mathrm{E}-09$ \\
\hline BKV1-16.12 & - & 23 & $2.1 \mathrm{E}-05$ & 15.07 & 10.0 & 1.999 & $4.00 \mathrm{E}-02$ & 168 & $4.75 \mathrm{E}-03$ & 559 & $6.22 \mathrm{E}-03$ & 1,815 & $5.16 \mathrm{E}-03$ & 2,297 & $4.45 \mathrm{E}-03$ & $1.65 \mathrm{E}-10$ \\
\hline
\end{tabular}


Table B1. SPFT Temperature Sweep, Experimental Conditions, and Dissolution Rates. Data in parenthesis are near quantification limit.

\begin{tabular}{|c|c|c|c|c|c|c|c|c|c|c|c|c|c|c|c|c|}
\hline$\underline{\text { Sample ID }}$ & $\begin{array}{l}\text { Influent Si } \\
\underline{\left(\mu \mathrm{g} \mathrm{L}^{-1}\right)}\end{array}$ & $\frac{\mathrm{T}}{\left({ }^{\circ} \mathrm{C}\right)}$ & $\begin{array}{l}\text { Flow Rate } \\
\underline{\left(\mathrm{m}^{3} / \mathrm{day}\right)}\end{array}$ & $\begin{array}{l}\text { Time } \\
\underline{\text { (days) }}\end{array}$ & $\begin{array}{c}\mathrm{pH} \\
\left(23^{\circ} \mathrm{C}\right) \\
\end{array}$ & $\begin{array}{l}\text { Mass } \\
\underline{(\mathrm{g})}\end{array}$ & $\begin{array}{l}\text { Sur. Area } \\
\qquad\left(\mathrm{m}^{2}\right)\end{array}$ & $\begin{array}{c}B \\
\left(\mu \mathrm{g} \mathrm{L}^{-1}\right) \\
\end{array}$ & $\begin{array}{c}\text { B Rate } \\
\left(\mathrm{g} \mathrm{m}^{-2} \mathrm{~d}^{-1}\right) \\
\end{array}$ & $\begin{array}{c}\mathrm{Al} \\
\underline{\left(\mu \mathrm{g} \mathrm{L}^{-1}\right)} \\
\end{array}$ & $\begin{array}{c}\text { Al Rate } \\
\left(\mathrm{g} \mathrm{m}^{-2} \mathrm{~d}^{-1}\right) \\
\end{array}$ & $\begin{array}{c}\mathrm{Na} \\
\underline{\left(\mu g \mathrm{~L}^{-1}\right)} \\
\end{array}$ & $\begin{array}{l}\text { Na Rate } \\
\underline{\left(\mathrm{g} \mathrm{m}^{-2} \mathrm{~d}^{-1}\right)} \\
\end{array}$ & $\begin{array}{c}\mathrm{Si} \\
\underline{\left(\mu \mathrm{g} \mathrm{L}^{-1}\right)} \\
\end{array}$ & $\begin{array}{l}\text { Si Rate } \\
\left(\mathrm{g} \mathrm{m}^{-2} \mathrm{~d}^{-1}\right) \\
\end{array}$ & $\begin{array}{l}\text { IEX Rate } \\
\left(\mathrm{mol} \mathrm{m}^{-2} \mathrm{~s}^{-1}\right) \\
\end{array}$ \\
\hline BKV1-16.17 & - & 23 & $2.2 \mathrm{E}-05$ & 21.13 & 10.0 & 1.999 & $3.99 \mathrm{E}-02$ & 158 & $4.49 \mathrm{E}-03$ & 462 & $5.24 \mathrm{E}-03$ & 1,639 & $4.75 \mathrm{E}-03$ & 2,112 & $4.10 \mathrm{E}-03$ & $1.06 \mathrm{E}-10$ \\
\hline BKV1-16.22 & - & 23 & $2.1 \mathrm{E}-05$ & 27.06 & 10.0 & 1.998 & $3.99 \mathrm{E}-02$ & 184 & $5.38 \mathrm{E}-03$ & 614 & $6.81 \mathrm{E}-03$ & 1,808 & $5.12 \mathrm{E}-03$ & 2,510 & $4.95 \mathrm{E}-03$ & 0.00 \\
\hline BKV1-16.24 & - & 23 & $2.2 \mathrm{E}-05$ & 29.08 & 10.0 & 1.997 & $3.99 \mathrm{E}-02$ & 179 & $5.48 \mathrm{E}-03$ & 585 & $6.87 \mathrm{E}-03$ & 1,811 & $5.43 \mathrm{E}-03$ & 2,415 & $5.01 \mathrm{E}-03$ & 0.00 \\
\hline BKV1-16.25 & - & 23 & $1.9 \mathrm{E}-05$ & 29.97 & 10.0 & 1.997 & $3.99 \mathrm{E}-02$ & 187 & $5.12 \mathrm{E}-03$ & 594 & $6.13 \mathrm{E}-03$ & 1,805 & $4.75 \mathrm{E}-03$ & 2,507 & $4.60 \mathrm{E}-03$ & 0.00 \\
\hline \multicolumn{17}{|l|}{ Exp. \#17 } \\
\hline BKV1-17.0 & - & 23 & - & - & 11.0 & - & - & $<50$ & - & 10 & - & $<100$ & - & $<500$ & - & - \\
\hline BKV1-17.1 & - & 23 & - & - & 11.0 & - & - & $<50$ & - & 13 & - & $<100$ & - & $<500$ & - & - \\
\hline BKV1-17.2 & - & 23 & - & - & 11.0 & - & - & $<50$ & - & 18 & - & $<100$ & - & $<500$ & - & - \\
\hline BKV1-17.3 & - & 23 & $2.2 \mathrm{E}-05$ & 4.13 & 11.0 & 1.000 & $2.00 \mathrm{E}-02$ & 112 & $5.15 \mathrm{E}-03$ & 458 & $1.04 \mathrm{E}-02$ & 2,187 & $1.30 \mathrm{E}-02$ & 1,930 & $7.31 \mathrm{E}-03$ & $3.12 \mathrm{E}-09$ \\
\hline BKV1-17.5 & - & 23 & $2.0 \mathrm{E}-05$ & 6.04 & 11.0 & 0.999 & $2.00 \mathrm{E}-02$ & 264 & $1.64 \mathrm{E}-02$ & 906 & $1.92 \mathrm{E}-02$ & 3,048 & $1.68 \mathrm{E}-02$ & 3,684 & $1.50 \mathrm{E}-02$ & $1.89 \mathrm{E}-10$ \\
\hline BKV1-17.7 & - & 23 & $2.2 \mathrm{E}-05$ & 8.09 & 11.0 & 0.998 & $2.00 \mathrm{E}-02$ & 310 & $2.23 \mathrm{E}-02$ & 1,046 & $2.49 \mathrm{E}-02$ & 3,188 & $1.98 \mathrm{E}-02$ & 4,173 & $1.93 \mathrm{E}-02$ & 0.00 \\
\hline BKV1-17.9 & - & 23 & $2.3 \mathrm{E}-05$ & 10.15 & 11.0 & 0.998 & $1.99 \mathrm{E}-02$ & 315 & $2.31 \mathrm{E}-02$ & 1,029 & $2.49 \mathrm{E}-02$ & 3,046 & $1.92 \mathrm{E}-02$ & 4,151 & $1.96 \mathrm{E}-02$ & 0.00 \\
\hline BKV1-17.12 & - & 23 & $2.3 \mathrm{E}-05$ & 15.07 & 11.0 & 0.997 & $1.99 \mathrm{E}-02$ & 360 & $2.75 \mathrm{E}-02$ & 1,176 & $2.90 \mathrm{E}-02$ & 3,368 & $2.16 \mathrm{E}-02$ & 4,732 & $2.30 \mathrm{E}-02$ & 0.00 \\
\hline BKV1-17.17 & - & 23 & $2.1 \mathrm{E}-05$ & 21.13 & 11.0 & 0.996 & $1.99 \mathrm{E}-02$ & 349 & $2.47 \mathrm{E}-02$ & 1,155 & $2.65 \mathrm{E}-02$ & 3,322 & $1.98 \mathrm{E}-02$ & 4,647 & $2.10 \mathrm{E}-02$ & 0.00 \\
\hline BKV1-17.22 & - & 23 & $2.2 \mathrm{E}-05$ & 27.06 & 11.0 & 0.994 & $1.99 \mathrm{E}-02$ & 372 & $2.75 \mathrm{E}-02$ & 1,219 & $2.90 \mathrm{E}-02$ & 3,477 & $2.15 \mathrm{E}-02$ & 4,981 & $2.35 \mathrm{E}-02$ & 0.00 \\
\hline BKV1-17.25 & - & 23 & $2.0 \mathrm{E}-05$ & 29.97 & 11.0 & 0.992 & $1.98 \mathrm{E}-02$ & 366 & $2.41 \mathrm{E}-02$ & 1,136 & $2.41 \mathrm{E}-02$ & 3,253 & $1.79 \mathrm{E}-02$ & 4,829 & $2.02 \mathrm{E}-02$ & 0.00 \\
\hline \multicolumn{17}{|l|}{ Exp. \#18 } \\
\hline BKV1-18.0 & - & 23 & - & - & 12.0 & - & - & $<50$ & - & 16 & - & $<100$ & - & $<500$ & - & - \\
\hline BKV1-18.1 & - & 23 & - & - & 12.0 & - & - & $<50$ & - & 24 & - & $<100$ & - & $<500$ & - & - \\
\hline BKV1-18.2 & - & 23 & - & - & 12.0 & - & - & $<50$ & - & 42 & - & $<100$ & - & $<500$ & - & - \\
\hline BKV1-18.3 & - & 23 & $2.0 \mathrm{E}-05$ & 4.13 & 12.0 & 1.001 & $2.00 \mathrm{E}-02$ & 180 & $9.93 \mathrm{E}-03$ & 700 & $1.44 \mathrm{E}-02$ & 2,564 & $1.40 \mathrm{E}-02$ & 2,782 & $1.07 \mathrm{E}-02$ & $1.63 \mathrm{E}-09$ \\
\hline BKV1-18.5 & - & 23 & $2.0 \mathrm{E}-05$ & 6.04 & 12.0 & 0.999 & $2.00 \mathrm{E}-02$ & 558 & $3.92 \mathrm{E}-02$ & 1,949 & 4.17E-02 & 5,561 & $3.14 \mathrm{E}-02$ & 7,609 & $3.36 \mathrm{E}-02$ & 0.00 \\
\hline BKV1-18.7 & - & 23 & $2.2 \mathrm{E}-05$ & 8.09 & 12.0 & 0.998 & $2.00 \mathrm{E}-02$ & 690 & $5.42 \mathrm{E}-02$ & 2,416 & $5.69 \mathrm{E}-02$ & 6,585 & $4.10 \mathrm{E}-02$ & 9,232 & $4.54 \mathrm{E}-02$ & 0.00 \\
\hline BKV1-18.9 & - & 23 & $2.2 \mathrm{E}-05$ & 10.15 & 12.0 & 0.996 & $1.99 \mathrm{E}-02$ & 698 & $5.56 \mathrm{E}-02$ & 2,394 & $5.72 \mathrm{E}-02$ & 6,590 & $4.15 \mathrm{E}-02$ & 9,305 & 4.64E-02 & 0.00 \\
\hline BKV1-18.12 & - & 23 & $2.2 \mathrm{E}-05$ & 15.07 & 12.0 & 0.994 & $1.99 \mathrm{E}-02$ & 807 & $6.53 \mathrm{E}-02$ & 2,727 & $6.55 \mathrm{E}-02$ & 7,589 & $4.82 \mathrm{E}-02$ & 10,871 & $5.49 \mathrm{E}-02$ & 0.00 \\
\hline BKV1-18.17 & - & 23 & $2.2 \mathrm{E}-05$ & 21.13 & 12.0 & 0.992 & $1.98 \mathrm{E}-02$ & 764 & $5.96 \mathrm{E}-02$ & 2,603 & $6.05 \mathrm{E}-02$ & 7,396 & $4.54 \mathrm{E}-02$ & 10,310 & $5.02 \mathrm{E}-02$ & 0.00 \\
\hline BKV1-18.22 & - & 23 & $2.1 \mathrm{E}-05$ & 27.06 & 12.0 & 0.988 & $1.98 \mathrm{E}-02$ & 799 & $6.21 \mathrm{E}-02$ & 2,675 & $6.18 \mathrm{E}-02$ & 7,858 & $4.80 \mathrm{E}-02$ & 10,514 & $5.10 \mathrm{E}-02$ & 0.00 \\
\hline BKV1-18.24 & - & 23 & $2.3 \mathrm{E}-05$ & 29.08 & 12.0 & 0.985 & $1.97 \mathrm{E}-02$ & 745 & $6.24 \mathrm{E}-02$ & 2,467 & $6.16 \mathrm{E}-02$ & 6,943 & $4.58 \mathrm{E}-02$ & 9,893 & $5.17 \mathrm{E}-02$ & 0.00 \\
\hline BKV1-18.25 & - & 23 & $2.0 \mathrm{E}-05$ & 29.97 & 12.0 & 0.984 & $1.97 \mathrm{E}-02$ & 793 & $5.67 \mathrm{E}-02$ & 2,557 & $5.43 \mathrm{E}-02$ & 7,514 & $4.22 \mathrm{E}-02$ & 10,299 & $4.59 \mathrm{E}-02$ & 0.00 \\
\hline \multicolumn{17}{|l|}{ Exp. \#19 } \\
\hline BKV1-19A & - & 90 & - & - & 7.0 & - & - & $<50$ & - & $<50$ & - & 79 & - & $<500$ & - & - \\
\hline BKV1-19B & - & 90 & - & - & 7.0 & - & - & $<50$ & - & $<50$ & - & 89 & - & $<500$ & - & - \\
\hline
\end{tabular}


Table B1. SPFT Temperature Sweep, Experimental Conditions, and Dissolution Rates. Data in parenthesis are near quantification limit.

\begin{tabular}{|c|c|c|c|c|c|c|c|c|c|c|c|c|c|c|c|c|}
\hline & Influent $\mathrm{Si}$ & & Flow Rate & Time & $\mathrm{pH}$ & Mass & Sur. Area & B & B Rate & $\mathrm{Al}$ & Al Rate & $\mathrm{Na}$ & Na Rate & $\mathrm{Si}$ & Si Rate & IEX Rate \\
\hline$\underline{\text { Sample ID }}$ & $\underline{\left(\mu g \mathrm{~L}^{-1}\right)}$ & $\frac{\mathrm{T}}{\left({ }^{\circ} \mathrm{C}\right)}$ & $\left(\mathrm{m}^{3} / \mathrm{day}\right)$ & $\underline{\text { (days) }}$ & $\underline{\left(23^{\circ} \mathrm{C}\right)}$ & $\underline{(\mathrm{g})}$ & $\left(\mathrm{m}^{2}\right)$ & $\underline{\left(\mu g \mathrm{~L}^{-1}\right)}$ & $\underline{\left(\mathrm{g} \mathrm{m}^{-2} \mathrm{~d}^{-1}\right)}$ & $\underline{\left(\mu g \mathrm{~L}^{-1}\right)}$ & $\underline{\left(\mathrm{g} \mathrm{m}^{-2} \mathrm{~d}^{-1}\right)}$ & $\underline{\left(\mu g \mathrm{~L}^{-1}\right)}$ & $\underline{\left(\mathrm{g} \mathrm{m}^{-2} \mathrm{~d}^{-1}\right)}$ & $\left.\underline{(\mu \mathrm{g} \mathrm{L}} \mathrm{L}^{-1}\right)$ & $\left(\mathrm{g} \mathrm{m}^{-2} \mathrm{~d}^{-1}\right)$ & $\left(\mathrm{mol} \mathrm{m}^{-2} \mathrm{~s}^{-1}\right)$ \\
\hline BKV1-19.3 & - & 90 & 4.7E-05 & 2.89 & 7.0 & 1.001 & $2.00 \mathrm{E}-02$ & 317 & 4.84E-02 & 124 & $3.76 \mathrm{E}-03$ & 17,496 & $2.36 \mathrm{E}-01$ & 1,029 & $5.89 \mathrm{E}-03$ & $7.48 \mathrm{E}-08$ \\
\hline BKV1-19.7 & - & 90 & $3.2 \mathrm{E}-05$ & 6.99 & 7.0 & 0.998 & $2.00 \mathrm{E}-02$ & 172 & $1.51 \mathrm{E}-02$ & 120 & $2.43 \mathrm{E}-03$ & 9,112 & $8.33 \mathrm{E}-02$ & 936 & $3.32 \mathrm{E}-03$ & $2.72 \mathrm{E}-08$ \\
\hline BKV1-19.10 & - & 90 & $7.8 \mathrm{E}-05$ & 10.95 & 7.0 & 0.997 & $1.99 \mathrm{E}-02$ & 139 & $2.66 \mathrm{E}-02$ & 94 & $3.71 \mathrm{E}-03$ & 7,349 & $1.61 \mathrm{E}-01$ & 1,019 & $9.50 \mathrm{E}-03$ & $5.39 \mathrm{E}-08$ \\
\hline BKV1-19.15 & - & 90 & $5.5 \mathrm{E}-05$ & 16.79 & 7.0 & 0.996 & $1.99 \mathrm{E}-02$ & 116 & $1.40 \mathrm{E}-02$ & 70 & $1.21 \mathrm{E}-03$ & 5,603 & $8.74 \mathrm{E}-02$ & 1,098 & $7.80 \mathrm{E}-03$ & $2.93 \mathrm{E}-08$ \\
\hline BKV1-19.20 & - & 90 & 7.9E-05 & 21.75 & 7.0 & 0.995 & $1.99 \mathrm{E}-02$ & (99) & $1.50 \mathrm{E}-02$ & 59 & $7.65 \mathrm{E}-04$ & 4,907 & $1.09 \mathrm{E}-01$ & 1,147 & $1.21 \mathrm{E}-02$ & $3.76 \mathrm{E}-08$ \\
\hline \multicolumn{17}{|l|}{ Exp. \#20 } \\
\hline BKV1-20A & - & 90 & - & - & 8.0 & - & - & $<100$ & - & $<50$ & - & 62 & - & $<500$ & - & - \\
\hline BKV1-20B & - & 90 & - & - & 8.0 & - & - & $<100$ & - & $<50$ & - & 52 & - & $<500$ & - & - \\
\hline BKV1-20C & - & 90 & - & - & 8.0 & - & - & $<100$ & - & $<50$ & - & 58 & - & $<500$ & - & - \\
\hline BKV1-20.1 & - & 90 & $6.9 \mathrm{E}-05$ & 0.97 & 8.0 & 1.008 & $2.01 \mathrm{E}-02$ & 272 & $4.50 \mathrm{E}-02$ & 603 & 4.07E-02 & 19,029 & $3.71 \mathrm{E}-01$ & 3,114 & $4.20 \mathrm{E}-02$ & $1.30 \mathrm{E}-07$ \\
\hline BKV1-20.3 & - & 90 & $5.8 \mathrm{E}-05$ & 2.89 & 8.0 & 1.005 & $2.01 \mathrm{E}-02$ & 330 & $5.07 \mathrm{E}-02$ & 932 & $5.48 \mathrm{E}-02$ & 12,201 & $2.00 \mathrm{E}-01$ & 4,510 & $5.43 \mathrm{E}-02$ & 5.95E-08 \\
\hline BKV1-20.5 & - & 90 & $5.3 \mathrm{E}-05$ & 4.94 & 8.0 & 1.003 & $2.01 \mathrm{E}-02$ & 328 & $4.61 \mathrm{E}-02$ & 958 & $5.17 \mathrm{E}-02$ & 8,820 & $1.32 \mathrm{E}-01$ & 4,521 & 4.99E-02 & $3.44 \mathrm{E}-08$ \\
\hline BKV1-20.7 & - & 90 & $5.4 \mathrm{E}-05$ & 6.99 & 8.0 & 1.001 & $2.00 \mathrm{E}-02$ & 303 & 4.19E-02 & 904 & $4.96 \mathrm{E}-02$ & 7,265 & $1.11 \mathrm{E}-01$ & 4,270 & 4.78E-02 & $2.76 \mathrm{E}-08$ \\
\hline BKV1-20.15 & - & 90 & $5.3 \mathrm{E}-05$ & 20.75 & 8.0 & 0.997 & $1.99 \mathrm{E}-02$ & 225 & $2.56 \mathrm{E}-02$ & 662 & $3.53 \mathrm{E}-02$ & 5,135 & 7.77E-02 & 3,233 & $3.44 \mathrm{E}-02$ & $2.08 \mathrm{E}-08$ \\
\hline BKV1-20.20 & - & 90 & $5.3 \mathrm{E}-05$ & 25.71 & 8.0 & 0.995 & $1.99 \mathrm{E}-02$ & 178 & $1.58 \mathrm{E}-02$ & 533 & $2.77 \mathrm{E}-02$ & 4,640 & $6.95 \mathrm{E}-02$ & 2,576 & $2.59 \mathrm{E}-02$ & $2.15 \mathrm{E}-08$ \\
\hline BKV1-20.22 & - & 90 & $5.5 \mathrm{E}-05$ & 28.79 & 8.0 & 0.994 & $1.99 \mathrm{E}-02$ & 171 & $1.51 \mathrm{E}-02$ & 515 & $2.80 \mathrm{E}-02$ & 4,410 & $6.95 \mathrm{E}-02$ & 2,492 & 2.62E-02 & $2.17 \mathrm{E}-08$ \\
\hline \multicolumn{17}{|l|}{ Exp. \#21 } \\
\hline BKV1-21A & - & 90 & - & - & 9.0 & - & - & $<100$ & - & $<50$ & - & $<50$ & - & $<500$ & - & - \\
\hline BKV1-21B & - & 90 & - & - & 9.0 & - & - & $<100$ & - & $<50$ & - & 52 & - & $<500$ & - & - \\
\hline BKV1-21C & - & 90 & - & - & 9.0 & - & - & $<100$ & - & $<50$ & - & $<50$ & - & $<500$ & - & - \\
\hline BKV1-21.1 & - & 90 & $6.5 \mathrm{E}-05$ & 0.97 & 9.0 & 0.499 & $9.98 \mathrm{E}-03$ & 535 & $2.18 \mathrm{E}-01$ & 1,705 & $2.33 \mathrm{E}-01$ & 8,717 & $3.24 \mathrm{E}-01$ & 6,935 & $1.98 \mathrm{E}-01$ & $4.23 \mathrm{E}-08$ \\
\hline BKV1-21.3 & - & 90 & $5.7 \mathrm{E}-05$ & 2.89 & 9.0 & 0.495 & $9.92 \mathrm{E}-03$ & 639 & $2.38 \mathrm{E}-01$ & 1,965 & $2.38 \mathrm{E}-01$ & 7,367 & $2.41 \mathrm{E}-01$ & 8,287 & $2.11 \mathrm{E}-01$ & $1.18 \mathrm{E}-09$ \\
\hline BKV1-21.5 & - & 90 & $5.5 \mathrm{E}-05$ & 4.94 & 9.0 & 0.490 & $9.83 \mathrm{E}-03$ & 625 & $2.24 \mathrm{E}-01$ & 1,943 & $2.27 \mathrm{E}-01$ & 6,506 & $2.06 \mathrm{E}-01$ & 8,170 & $2.01 \mathrm{E}-01$ & 0.00 \\
\hline BKV1-21.7 & - & 90 & $6.0 \mathrm{E}-05$ & 6.99 & 9.0 & 0.486 & $9.74 \mathrm{E}-03$ & 602 & $2.38 \mathrm{E}-01$ & 1,892 & $2.46 \mathrm{E}-01$ & 6,234 & $2.19 \mathrm{E}-01$ & 7,925 & $2.16 \mathrm{E}-01$ & 0.00 \\
\hline BKV1-21.10 & - & 90 & $6.5 \mathrm{E}-05$ & 10.95 & 9.0 & 0.481 & $9.65 \mathrm{E}-03$ & 545 & $2.31 \mathrm{E}-01$ & 1,769 & $2.51 \mathrm{E}-01$ & 6,545 & $2.51 \mathrm{E}-01$ & 7,247 & $2.15 \mathrm{E}-01$ & $8.11 \mathrm{E}-09$ \\
\hline BKV1-21.15 & - & 90 & $5.6 \mathrm{E}-05$ & 20.75 & 9.0 & 0.475 & $9.54 \mathrm{E}-03$ & 538 & $1.97 \mathrm{E}-01$ & 1,738 & $2.13 \mathrm{E}-01$ & 5,777 & $1.92 \mathrm{E}-01$ & 7,169 & $1.84 \mathrm{E}-01$ & 0.00 \\
\hline BKV1-21.20 & - & 90 & $5.9 \mathrm{E}-05$ & 25.71 & 9.0 & 0.471 & $9.44 \mathrm{E}-03$ & 529 & $2.07 \mathrm{E}-01$ & 1,708 & $2.25 \mathrm{E}-01$ & 4,621 & $1.64 \mathrm{E}-01$ & 7,101 & $1.95 \mathrm{E}-01$ & 0.00 \\
\hline BKV1-21.22 & - & 90 & $5.9 \mathrm{E}-05$ & 28.79 & 9.0 & 0.468 & $9.37 \mathrm{E}-03$ & 515 & $2.00 \mathrm{E}-01$ & 1,482 & $1.94 \mathrm{E}-01$ & 4,902 & $1.74 \mathrm{E}-01$ & 6,844 & $1.87 \mathrm{E}-01$ & 0.00 \\
\hline \multicolumn{17}{|l|}{ Exp. \#22 } \\
\hline
\end{tabular}


Table B1. SPFT Temperature Sweep, Experimental Conditions, and Dissolution Rates. Data in parenthesis are near quantification limit.

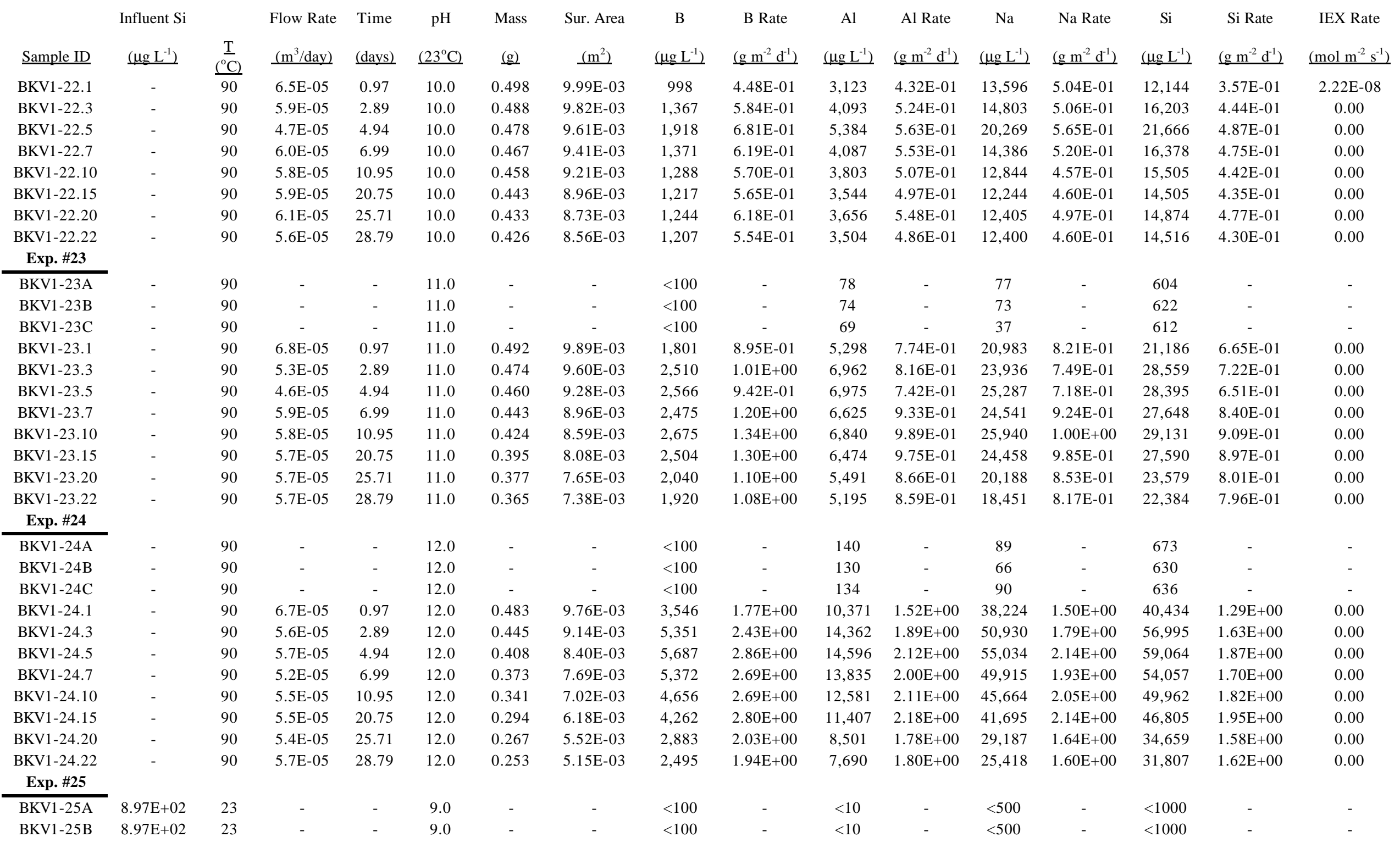


Table B1. SPFT Temperature Sweep, Experimental Conditions, and Dissolution Rates. Data in parenthesis are near quantification limit.

\begin{tabular}{|c|c|c|c|c|c|c|c|c|c|c|c|c|c|c|c|c|}
\hline & Influent $\mathrm{Si}$ & & Flow Rate & Time & $\mathrm{pH}$ & Mass & Sur. Area & B & B Rate & $\mathrm{Al}$ & Al Rate & $\mathrm{Na}$ & Na Rate & $\mathrm{Si}$ & Si Rate & IEX Rate \\
\hline$\underline{\text { Sample ID }}$ & $\underline{\left(\mu g \mathrm{~L}^{-1}\right)}$ & $\frac{\mathrm{T}}{\left({ }^{\circ} \mathrm{C}\right)}$ & $\underline{\left(\mathrm{m}^{3} / \mathrm{day}\right)}$ & $\underline{\text { (days) }}$ & $\underline{\left(23^{\circ} \mathrm{C}\right)}$ & $\underline{(\mathrm{g})}$ & $\underline{\left(\mathrm{m}^{2}\right)}$ & $\underline{\left(\mu g \mathrm{~L}^{-1}\right)}$ & $\underline{\left(\mathrm{g} \mathrm{m}^{-2} \mathrm{~d}^{-1}\right)}$ & $\underline{\left(\mu g \mathrm{~L}^{-1}\right)}$ & $\underline{\left(\mathrm{g} \mathrm{m}^{-2} \mathrm{~d}^{-1}\right)}$ & $\underline{\left(\mu g \mathrm{~L}^{-1}\right)}$ & $\underline{\left(\mathrm{g} \mathrm{m}^{-2} \mathrm{~d}^{-1}\right)}$ & $\underline{\left(\mu g \mathrm{~L}^{-1}\right)}$ & $\underline{\left(\mathrm{g} \mathrm{m}^{-2} \mathrm{~d}^{-1}\right)}$ & $\underline{\left(\mathrm{mol} \mathrm{m}^{-2} \mathrm{~s}^{-1}\right)}$ \\
\hline BKV1-25C & $8.97 \mathrm{E}+02$ & 23 & - & - & 9.0 & - & - & $<100$ & - & $<10$ & - & $<500$ & - & $<1000$ & - & - \\
\hline BKV1-25.1 & $8.97 \mathrm{E}+02$ & 23 & $9.6 \mathrm{E}-06$ & 2.09 & 9.0 & 6.005 & $1.20 \mathrm{E}-01$ & 149 & $2.98 \mathrm{E}-04$ & 195 & $3.19 \mathrm{E}-04$ & 8,866 & $3.82 \mathrm{E}-03$ & 1,155 & $5.83 \mathrm{E}-05$ & $1.41 \mathrm{E}-09$ \\
\hline BKV1-25.3 & $8.97 \mathrm{E}+02$ & 23 & $1.4 \mathrm{E}-05$ & 6.96 & 9.0 & 6.004 & $1.20 \mathrm{E}-01$ & 168 & $6.02 \mathrm{E}-04$ & 424 & $1.03 \mathrm{E}-03$ & 8,913 & $5.56 \mathrm{E}-03$ & 2,077 & $5.86 \mathrm{E}-04$ & $1.98 \mathrm{E}-09$ \\
\hline BKV1-25.5 & $8.97 \mathrm{E}+02$ & 23 & $6.3 \mathrm{E}-06$ & 12.20 & 9.0 & 6.004 & $1.20 \mathrm{E}-01$ & 157 & $2.27 \mathrm{E}-04$ & 448 & $4.92 \mathrm{E}-04$ & 6,776 & $1.87 \mathrm{E}-03$ & 2,120 & $2.75 \mathrm{E}-04$ & $6.56 \mathrm{E}-10$ \\
\hline BKV1-25.8 & $8.97 \mathrm{E}+02$ & 23 & $9.6 \mathrm{E}-06$ & 16.28 & 9.0 & 6.004 & $1.20 \mathrm{E}-01$ & 134 & $2.11 \mathrm{E}-04$ & 392 & $6.59 \mathrm{E}-04$ & 4,742 & $1.94 \mathrm{E}-03$ & 1,822 & $3.10 \mathrm{E}-04$ & $6.90 \mathrm{E}-10$ \\
\hline BKV1-25.9 & $8.97 \mathrm{E}+02$ & 23 & $9.5 \mathrm{E}-06$ & 18.25 & 9.0 & 6.003 & $1.20 \mathrm{E}-01$ & 139 & $2.35 \mathrm{E}-04$ & 437 & $7.29 \mathrm{E}-04$ & 4,410 & $1.77 \mathrm{E}-03$ & 1,956 & $3.56 \mathrm{E}-04$ & $6.13 \mathrm{E}-10$ \\
\hline BKV1-25.12 & $8.97 \mathrm{E}+02$ & 23 & $9.5 \mathrm{E}-06$ & 24.25 & 9.0 & 6.003 & $1.20 \mathrm{E}-01$ & 183 & $5.00 \mathrm{E}-04$ & 592 & $9.92 \mathrm{E}-04$ & 3,431 & $1.32 \mathrm{E}-03$ & 2,653 & $6.14 \mathrm{E}-04$ & $3.29 \mathrm{E}-10$ \\
\hline BKV1-25.13 & $8.97 \mathrm{E}+02$ & 23 & $9.6 \mathrm{E}-06$ & 26.21 & 9.0 & 6.002 & $1.20 \mathrm{E}-01$ & 190 & $5.47 \mathrm{E}-04$ & 610 & $1.03 \mathrm{E}-03$ & 3,210 & $1.23 \mathrm{E}-03$ & 2,750 & $6.56 \mathrm{E}-04$ & $2.74 \mathrm{E}-10$ \\
\hline BKV1-25.14 & $8.97 \mathrm{E}+02$ & 23 & $9.5 \mathrm{E}-06$ & 28.14 & 9.0 & 6.002 & $1.20 \mathrm{E}-01$ & 194 & $5.72 \mathrm{E}-04$ & 613 & $1.03 \mathrm{E}-03$ & 3,095 & $1.17 \mathrm{E}-03$ & 2,795 & $6.67 \mathrm{E}-04$ & $2.40 \mathrm{E}-10$ \\
\hline $\begin{array}{c}\text { BKV1-25.15 } \\
\text { Exp. \#26 }\end{array}$ & $8.97 \mathrm{E}+02$ & 23 & 8.7E-06 & 33.54 & 9.0 & 6.001 & $1.20 \mathrm{E}-01$ & 205 & $5.84 \mathrm{E}-04$ & 619 & $9.51 \mathrm{E}-04$ & 2,911 & $9.97 \mathrm{E}-04$ & 2,861 & $6.33 \mathrm{E}-04$ & $1.65 \mathrm{E}-10$ \\
\hline BKV1-26A & $1.51 \mathrm{E}+04$ & 23 & - & - & 9.0 & - & - & $<50$ & - & $<10$ & - & $<500$ & - & 16,575 & - & - \\
\hline BKV1-26B & $1.51 \mathrm{E}+04$ & 23 & - & - & 9.0 & - & - & $<50$ & - & $<10$ & - & $<500$ & - & 16,638 & - & - \\
\hline BKV1-26C & $1.51 \mathrm{E}+04$ & 23 & - & - & 9.0 & - & - & $<50$ & - & $<10$ & - & $<500$ & - & 17,341 & - & - \\
\hline BKV1-26.3 & $1.51 \mathrm{E}+04$ & 23 & $1.4 \mathrm{E}-05$ & 6.96 & 9.0 & 6.004 & $1.20 \mathrm{E}-01$ & 144 & 8.43E-04 & 198 & 4.77E-04 & 7,249 & $4.53 \mathrm{E}-03$ & 15,592 & - & $1.47 \mathrm{E}-09$ \\
\hline BKV1-26.5 & $1.51 \mathrm{E}+04$ & 23 & $6.2 \mathrm{E}-06$ & 12.20 & 9.0 & 6.004 & $1.20 \mathrm{E}-01$ & 111 & 2.39E-04 & 209 & $2.20 \mathrm{E}-04$ & 7,391 & $2.02 \mathrm{E}-03$ & 18,385 & $3.70 \mathrm{E}-04$ & $7.11 \mathrm{E}-10$ \\
\hline BKV1-26.8 & $1.51 \mathrm{E}+04$ & 23 & $9.4 \mathrm{E}-06$ & 16.28 & 9.0 & 6.004 & $1.20 \mathrm{E}-01$ & (70) & $1.20 \mathrm{E}-04$ & 153 & $2.41 \mathrm{E}-04$ & 4,872 & $1.95 \mathrm{E}-03$ & 17,470 & $2.27 \mathrm{E}-04$ & $7.32 \mathrm{E}-10$ \\
\hline BKV1-26.9 & $1.51 \mathrm{E}+04$ & 23 & $9.4 \mathrm{E}-06$ & 18.25 & 9.0 & 6.004 & $1.20 \mathrm{E}-01$ & (64) & 8.72E-05 & 160 & $2.54 \mathrm{E}-04$ & 4,234 & $1.68 \mathrm{E}-03$ & 17,577 & $2.68 \mathrm{E}-04$ & $6.34 \mathrm{E}-10$ \\
\hline BKV1-26.11 & $1.51 \mathrm{E}+04$ & 23 & $9.6 \mathrm{E}-06$ & 22.20 & 9.0 & 6.004 & $1.20 \mathrm{E}-01$ & (70) & $1.22 \mathrm{E}-04$ & 224 & $3.70 \mathrm{E}-04$ & 3,429 & $1.34 \mathrm{E}-03$ & 18,202 & $5.09 \mathrm{E}-04$ & $4.87 \mathrm{E}-10$ \\
\hline BKV1-26.12 & $1.51 \mathrm{E}+04$ & 23 & $9.3 \mathrm{E}-06$ & 24.25 & 9.0 & 6.003 & $1.20 \mathrm{E}-01$ & (78) & $1.67 \mathrm{E}-04$ & 266 & $4.29 \mathrm{E}-04$ & 3,316 & $1.25 \mathrm{E}-03$ & 18,494 & $6.01 \mathrm{E}-04$ & $4.33 \mathrm{E}-10$ \\
\hline BKV1-26.13 & $1.51 \mathrm{E}+04$ & 23 & $9.5 \mathrm{E}-06$ & 26.21 & 9.0 & 6.003 & $1.20 \mathrm{E}-01$ & (76) & $1.59 \mathrm{E}-04$ & 247 & $4.05 \mathrm{E}-04$ & 2,285 & $8.08 \mathrm{E}-04$ & 16,154 & 0.00 & $2.59 \mathrm{E}-10$ \\
\hline BKV1-26.14 & $1.51 \mathrm{E}+04$ & 23 & $9.3 \mathrm{E}-06$ & 28.14 & 9.0 & 6.003 & $1.20 \mathrm{E}-01$ & (82) & $1.90 \mathrm{E}-04$ & 273 & $4.41 \mathrm{E}-04$ & 2,573 & $9.22 \mathrm{E}-04$ & 17,509 & $2.41 \mathrm{E}-04$ & $2.92 \mathrm{E}-10$ \\
\hline $\begin{array}{c}\text { BKV1-26.15 } \\
\text { Exp. \#27 }\end{array}$ & $1.51 \mathrm{E}+04$ & 23 & $8.4 \mathrm{E}-06$ & 33.54 & 9.0 & 6.003 & $1.20 \mathrm{E}-01$ & (94) & 2.39E-04 & 311 & $4.55 \mathrm{E}-04$ & 2,938 & $9.77 \mathrm{E}-04$ & 19,874 & $9.97 \mathrm{E}-04$ & $2.95 \mathrm{E}-10$ \\
\hline BKV1-27A & $3.01 \mathrm{E}+04$ & 23 & - & - & 9.0 & - & - & $<25$ & - & $<10$ & - & $<500$ & - & 33,583 & - & - \\
\hline BKV1-27B & $3.01 \mathrm{E}+04$ & 23 & - & - & 9.0 & - & - & $<25$ & - & $<10$ & - & $<500$ & - & 33,647 & - & - \\
\hline BKV1-27C & $3.01 \mathrm{E}+04$ & 23 & - & - & 9.0 & - & - & $<25$ & - & $<10$ & - & $<500$ & - & 33,494 & - & - \\
\hline BKV1-27.1 & $3.01 \mathrm{E}+04$ & 23 & $9.5 \mathrm{E}-06$ & 2.09 & 9.0 & 6.013 & $1.20 \mathrm{E}-01$ & 145 & 7.34E-04 & 131 & 2.07E-04 & 8,127 & $3.46 \mathrm{E}-03$ & 33,628 & $2.01 \mathrm{E}-05$ & $1.09 \mathrm{E}-09$ \\
\hline BKV1-27.3 & $3.01 \mathrm{E}+04$ & 23 & $1.4 \mathrm{E}-05$ & 6.96 & 9.0 & 6.012 & $1.20 \mathrm{E}-01$ & 119 & $8.20 \mathrm{E}-04$ & 155 & $3.58 \mathrm{E}-04$ & 7,504 & $4.58 \mathrm{E}-03$ & 33,594 & $1.05 \mathrm{E}-05$ & $1.50 \mathrm{E}-09$ \\
\hline BKV1-27.5 & $3.01 \mathrm{E}+04$ & 23 & $6.4 \mathrm{E}-06$ & 12.20 & 9.0 & 6.012 & $1.20 \mathrm{E}-01$ & (80) & $2.27 \mathrm{E}-04$ & 128 & $1.36 \mathrm{E}-04$ & 5,725 & $1.60 \mathrm{E}-03$ & 33,808 & $5.88 \mathrm{E}-05$ & $5.46 \mathrm{E}-10$ \\
\hline BKV1-27.8 & $3.01 \mathrm{E}+04$ & 23 & $9.7 \mathrm{E}-06$ & 16.28 & 9.0 & 6.012 & $1.20 \mathrm{E}-01$ & (52) & $1.66 \mathrm{E}-04$ & 95 & $1.48 \mathrm{E}-04$ & 4,337 & $1.78 \mathrm{E}-03$ & 34,011 & $1.67 \mathrm{E}-04$ & $6.44 \mathrm{E}-10$ \\
\hline BKV1-27.12 & $3.01 \mathrm{E}+04$ & 23 & $9.6 \mathrm{E}-06$ & 24.25 & 9.0 & 6.012 & $1.20 \mathrm{E}-01$ & (51) & $1.57 \mathrm{E}-04$ & 148 & $2.38 \mathrm{E}-04$ & 3,255 & $1.26 \mathrm{E}-03$ & 34,777 & $4.51 \mathrm{E}-04$ & $4.39 \mathrm{E}-10$ \\
\hline
\end{tabular}


Table B1. SPFT Temperature Sweep, Experimental Conditions, and Dissolution Rates. Data in parenthesis are near quantification limit.

\begin{tabular}{|c|c|c|c|c|c|c|c|c|c|c|c|c|c|c|c|c|}
\hline$\underline{\text { Sample ID }}$ & $\begin{array}{l}\text { Influent Si } \\
\qquad \underline{\left(\mu g \mathrm{~L}^{-1}\right)}\end{array}$ & $\frac{\mathrm{T}}{\left({ }^{\circ} \mathrm{C}\right)}$ & $\begin{array}{l}\text { Flow Rate } \\
\left(\mathrm{m}^{3} / \mathrm{day}\right) \\
\end{array}$ & $\begin{array}{l}\text { Time } \\
\underline{\text { (days) }}\end{array}$ & $\begin{array}{c}\mathrm{pH} \\
\left(23^{\circ} \mathrm{C}\right) \\
\end{array}$ & $\begin{array}{l}\text { Mass } \\
\underline{(\mathrm{g})}\end{array}$ & $\begin{array}{l}\text { Sur. Area } \\
\qquad\left(\mathrm{m}^{2}\right)\end{array}$ & $\begin{array}{c}B \\
\left(\mu g \mathrm{~L}^{-1}\right) \\
\end{array}$ & $\begin{array}{c}\text { B Rate } \\
\left(\mathrm{g} \mathrm{m}^{-2} \mathrm{~d}^{-1}\right) \\
\end{array}$ & $\begin{array}{c}\mathrm{Al} \\
\underline{\left(\mu \mathrm{g} \mathrm{L}^{-1}\right)} \\
\end{array}$ & $\begin{array}{l}\text { Al Rate } \\
\left(\mathrm{g} \mathrm{m}^{-2} \mathrm{~d}^{-1}\right) \\
\end{array}$ & $\begin{array}{c}\mathrm{Na} \\
\left(\mu \mathrm{g} \mathrm{L}^{-1}\right) \\
\end{array}$ & $\begin{array}{l}\text { Na Rate } \\
\underline{\left(\mathrm{g} \mathrm{m}^{-2} \mathrm{~d}^{-1}\right)} \\
\end{array}$ & $\begin{array}{c}\mathrm{Si} \\
\left(\mu \mathrm{g} \mathrm{L}^{-1}\right) \\
\end{array}$ & $\begin{array}{l}\text { Si Rate } \\
\left(\mathrm{g} \mathrm{m}^{-2} \mathrm{~d}^{-1}\right) \\
\end{array}$ & $\begin{array}{c}\text { IEX Rate } \\
\underline{\left(\mathrm{mol} \mathrm{m}^{-2} \mathrm{~s}^{-1}\right)}\end{array}$ \\
\hline BKV1-27.13 & $3.01 \mathrm{E}+04$ & 23 & $9.7 \mathrm{E}-06$ & 26.21 & 9.0 & 6.012 & $1.20 \mathrm{E}-01$ & (52) & $1.65 \mathrm{E}-04$ & 160 & 2.61E-04 & 3,063 & $1.18 \mathrm{E}-03$ & 34,715 & $4.34 \mathrm{E}-04$ & 4.07E-10 \\
\hline $\begin{array}{c}\text { BKV1-27.15 } \\
\text { Exp. \#28 }\end{array}$ & $3.01 \mathrm{E}+04$ & 23 & $8.7 \mathrm{E}-06$ & 33.54 & 9.0 & 6.011 & $1.20 \mathrm{E}-01$ & (53) & $1.57 \mathrm{E}-04$ & 159 & $2.34 \mathrm{E}-04$ & 2,464 & $8.14 \mathrm{E}-04$ & 34,981 & $4.80 \mathrm{E}-04$ & $2.62 \mathrm{E}-10$ \\
\hline BKV1-28A & $4.60 \mathrm{E}+04$ & 23 & - & - & & - & - & (20) & - & $<10$ & - & $<500$ & - & 50,284 & - & - \\
\hline BKV1-28B & $4.60 \mathrm{E}+04$ & 23 & - & - & & - & - & (9) & - & $<10$ & - & $<500$ & - & 51,432 & - & - \\
\hline BKV1-28C & $4.60 \mathrm{E}+04$ & 23 & - & - & & - & - & (5) & - & $<10$ & - & $<500$ & - & 52,215 & - & - \\
\hline BKV1-28.1 & $4.60 \mathrm{E}+04$ & 23 & $9.6 \mathrm{E}-06$ & 2.09 & 9.0 & 6.006 & $1.20 \mathrm{E}-01$ & 132 & $7.40 \mathrm{E}-04$ & 106 & $1.06 \mathrm{E}-01$ & 7,541 & $3.23 \mathrm{E}-03$ & 51,421 & $4.18 \mathrm{E}-05$ & $9.95 \mathrm{E}-10$ \\
\hline BKV1-28.3 & $4.60 \mathrm{E}+04$ & 23 & $1.4 \mathrm{E}-05$ & 6.96 & 9.0 & 6.005 & $1.20 \mathrm{E}-01$ & 109 & $8.73 \mathrm{E}-04$ & 113 & $1.13 \mathrm{E}-01$ & 7,924 & $4.97 \mathrm{E}-03$ & 51,752 & $2.44 \mathrm{E}-04$ & $1.64 \mathrm{E}-09$ \\
\hline BKV1-28.5 & $4.60 \mathrm{E}+04$ & 23 & $6.5 \mathrm{E}-06$ & 12.20 & 9.0 & 6.005 & $1.20 \mathrm{E}-01$ & (70) & $2.45 \mathrm{E}-04$ & 86 & $8.62 \mathrm{E}-02$ & 6,020 & $1.71 \mathrm{E}-03$ & 49,951 & 0.00 & $5.86 \mathrm{E}-10$ \\
\hline BKV1-28.8 & $4.60 \mathrm{E}+04$ & 23 & $9.7 \mathrm{E}-06$ & 16.28 & 9.0 & 6.005 & $1.20 \mathrm{E}-01$ & (43) & $1.98 \mathrm{E}-04$ & 64 & $6.37 \mathrm{E}-02$ & 4,499 & $1.85 \mathrm{E}-03$ & 51,235 & 0.00 & $6.59 \mathrm{E}-10$ \\
\hline BKV1-28.9 & $4.60 \mathrm{E}+04$ & 23 & $9.8 \mathrm{E}-06$ & 18.25 & 9.0 & 6.005 & $1.20 \mathrm{E}-01$ & (37) & $1.58 \mathrm{E}-04$ & 60 & $6.02 \mathrm{E}-02$ & 4,058 & $1.66 \mathrm{E}-03$ & 50,591 & 0.00 & $6.02 \mathrm{E}-10$ \\
\hline BKV1-28.11 & $4.60 \mathrm{E}+04$ & 23 & $9.9 \mathrm{E}-06$ & 22.20 & 9.0 & 6.005 & $1.20 \mathrm{E}-01$ & (33) & $1.34 \mathrm{E}-04$ & 69 & $6.87 \mathrm{E}-02$ & 3,519 & $1.42 \mathrm{E}-03$ & 51,851 & $2.09 \mathrm{E}-04$ & $5.13 \mathrm{E}-10$ \\
\hline BKV1-28.12 & $4.60 \mathrm{E}+04$ & 23 & $9.7 \mathrm{E}-06$ & 24.25 & 9.0 & 6.005 & $1.20 \mathrm{E}-01$ & (32) & $1.30 \mathrm{E}-04$ & 75 & 7.49E-02 & 3,457 & $1.36 \mathrm{E}-03$ & 52,435 & $4.27 \mathrm{E}-04$ & $4.93 \mathrm{E}-10$ \\
\hline BKV1-28.13 & $4.60 \mathrm{E}+04$ & 23 & $9.8 \mathrm{E}-06$ & 26.21 & 9.0 & 6.005 & $1.20 \mathrm{E}-01$ & (30) & $1.19 \mathrm{E}-04$ & 81 & $8.14 \mathrm{E}-02$ & 3,151 & $1.23 \mathrm{E}-03$ & 51,380 & $2.69 \mathrm{E}-05$ & $4.45 \mathrm{E}-10$ \\
\hline $\begin{array}{c}\text { BKV1-28.15 } \\
\text { Exp. \#29 }\end{array}$ & $4.60 \mathrm{E}+04$ & 23 & 8.9E-06 & 33.54 & 9.0 & 6.005 & $1.20 \mathrm{E}-01$ & (28) & $9.64 \mathrm{E}-05$ & 82 & $8.18 \mathrm{E}-02$ & 2,549 & 8.64E-04 & 51,021 & 0.00 & $3.07 \mathrm{E}-10$ \\
\hline BKV1-29A & $6.04 \mathrm{E}+04$ & 23 & - & - & 9.0 & - & - & (1) & - & $<10$ & - & $<500$ & - & 66,735 & - & - \\
\hline BKV1-29B & $6.04 \mathrm{E}+04$ & 23 & - & - & 9.0 & - & - & $(0)$ & - & $<10$ & - & $<500$ & - & 67,352 & - & - \\
\hline BKV1-29C & $6.04 \mathrm{E}+04$ & 23 & - & - & 9.0 & - & - & (0) & - & $<10$ & - & $<500$ & - & 67,815 & - & - \\
\hline BKV1-29.1 & $6.04 \mathrm{E}+04$ & 23 & $1.0 \mathrm{E}-05$ & 2.09 & 9.0 & 6.005 & $6.60 \mathrm{E}-02$ & 171 & $1.98 \mathrm{E}-03$ & 244 & $7.67 \mathrm{E}-04$ & 8,300 & $6.77 \mathrm{E}-03$ & 66,255 & 0.00 & $1.91 \mathrm{E}-09$ \\
\hline BKV1-29.3 & $6.04 \mathrm{E}+04$ & 23 & $1.4 \mathrm{E}-05$ & 6.96 & 9.0 & 6.004 & $1.20 \mathrm{E}-01$ & 103 & $9.19 \mathrm{E}-04$ & 91 & $2.04 \mathrm{E}-04$ & 8,134 & $5.08 \mathrm{E}-03$ & 66,341 & 0.00 & $1.66 \mathrm{E}-09$ \\
\hline BKV1-29.5 & $6.04 \mathrm{E}+04$ & 23 & $6.4 \mathrm{E}-06$ & 12.20 & 9.0 & 6.004 & $1.20 \mathrm{E}-01$ & (65) & $2.65 \mathrm{E}-04$ & 71 & $7.10 \mathrm{E}-05$ & 5,881 & $1.65 \mathrm{E}-03$ & 67,587 & $7.23 \mathrm{E}-05$ & $5.54 \mathrm{E}-10$ \\
\hline BKV1-29.8 & $6.04 \mathrm{E}+04$ & 23 & $9.6 \mathrm{E}-06$ & 16.28 & 9.0 & 6.004 & $1.20 \mathrm{E}-01$ & (36) & $2.17 \mathrm{E}-04$ & 43 & $5.74 \mathrm{E}-05$ & 4,394 & $1.78 \mathrm{E}-03$ & 67,400 & $3.73 E-05$ & $6.23 \mathrm{E}-10$ \\
\hline BKV1-29.9 & $6.04 \mathrm{E}+04$ & 23 & $9.7 \mathrm{E}-06$ & 18.25 & 9.0 & 6.004 & $1.20 \mathrm{E}-01$ & (31) & $1.87 \mathrm{E}-04$ & 41 & $5.46 \mathrm{E}-05$ & 4,229 & $1.72 \mathrm{E}-03$ & 67,260 & 0.00 & $6.11 \mathrm{E}-10$ \\
\hline BKV1-29.11 & $6.04 \mathrm{E}+04$ & 23 & $9.8 \mathrm{E}-06$ & 22.20 & 9.0 & 6.004 & $1.20 \mathrm{E}-01$ & (27) & $1.64 \mathrm{E}-04$ & 46 & $6.38 \mathrm{E}-05$ & 3,659 & $1.47 \mathrm{E}-03$ & 68,473 & 4.49E-04 & $5.22 \mathrm{E}-10$ \\
\hline BKV1-29.12 & $6.04 \mathrm{E}+04$ & 23 & $9.6 \mathrm{E}-06$ & 24.25 & 9.0 & 6.004 & $1.20 \mathrm{E}-01$ & (24) & $1.47 \mathrm{E}-04$ & 51 & $7.13 \mathrm{E}-05$ & 4,077 & $1.63 \mathrm{E}-03$ & 67,990 & $2.59 \mathrm{E}-04$ & $5.94 \mathrm{E}-10$ \\
\hline BKV1-29.13 & $6.04 \mathrm{E}+04$ & 23 & $9.7 \mathrm{E}-06$ & 26.21 & 9.0 & 6.004 & $1.20 \mathrm{E}-01$ & (23) & $1.38 \mathrm{E}-04$ & 59 & $8.45 \mathrm{E}-05$ & 3,535 & $1.40 \mathrm{E}-03$ & 67,788 & $1.85 \mathrm{E}-04$ & $5.04 \mathrm{E}-10$ \\
\hline BKV1-29.14 & $6.04 \mathrm{E}+04$ & 23 & $9.6 \mathrm{E}-06$ & 28.14 & 9.0 & 6.004 & $1.20 \mathrm{E}-01$ & (21) & $1.24 \mathrm{E}-04$ & 54 & $7.56 \mathrm{E}-05$ & 2,682 & $1.00 \mathrm{E}-03$ & 68,295 & $3.75 \mathrm{E}-04$ & $3.50 \mathrm{E}-10$ \\
\hline $\begin{array}{c}\text { BKV1-29.15 } \\
\text { Exp. \#30 }\end{array}$ & $6.04 \mathrm{E}+04$ & 23 & $8.7 \mathrm{E}-06$ & 33.54 & 9.0 & 6.004 & $1.20 \mathrm{E}-01$ & (19) & $1.04 \mathrm{E}-04$ & 47 & $5.74 \mathrm{E}-05$ & 2,630 & $8.85 \mathrm{E}-04$ & 67,407 & $3.63 \mathrm{E}-05$ & $3.11 \mathrm{E}-10$ \\
\hline
\end{tabular}


Table B1. SPFT Temperature Sweep, Experimental Conditions, and Dissolution Rates. Data in parenthesis are near quantification limit.

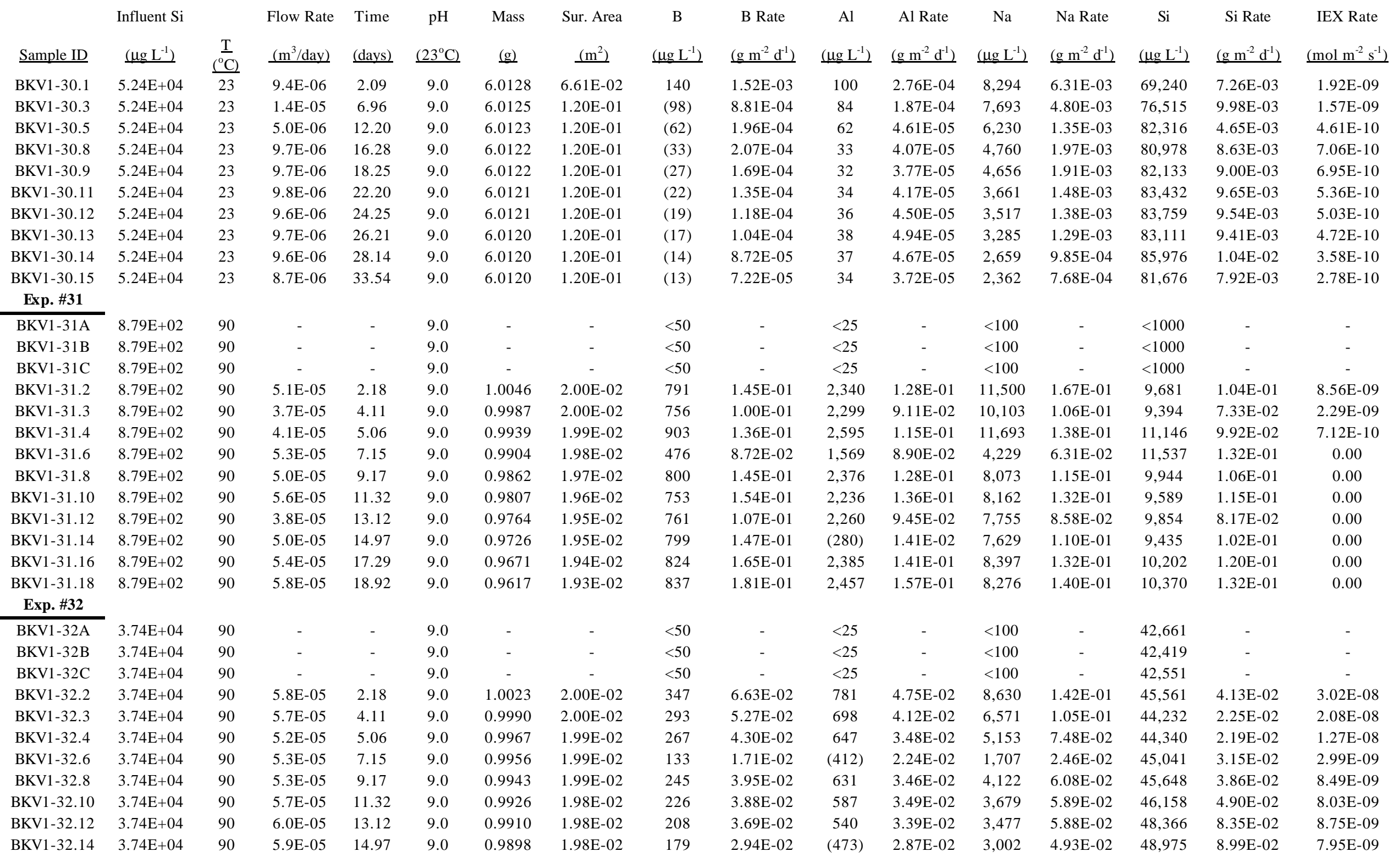


Table B1. SPFT Temperature Sweep, Experimental Conditions, and Dissolution Rates. Data in parenthesis are near quantification limit.

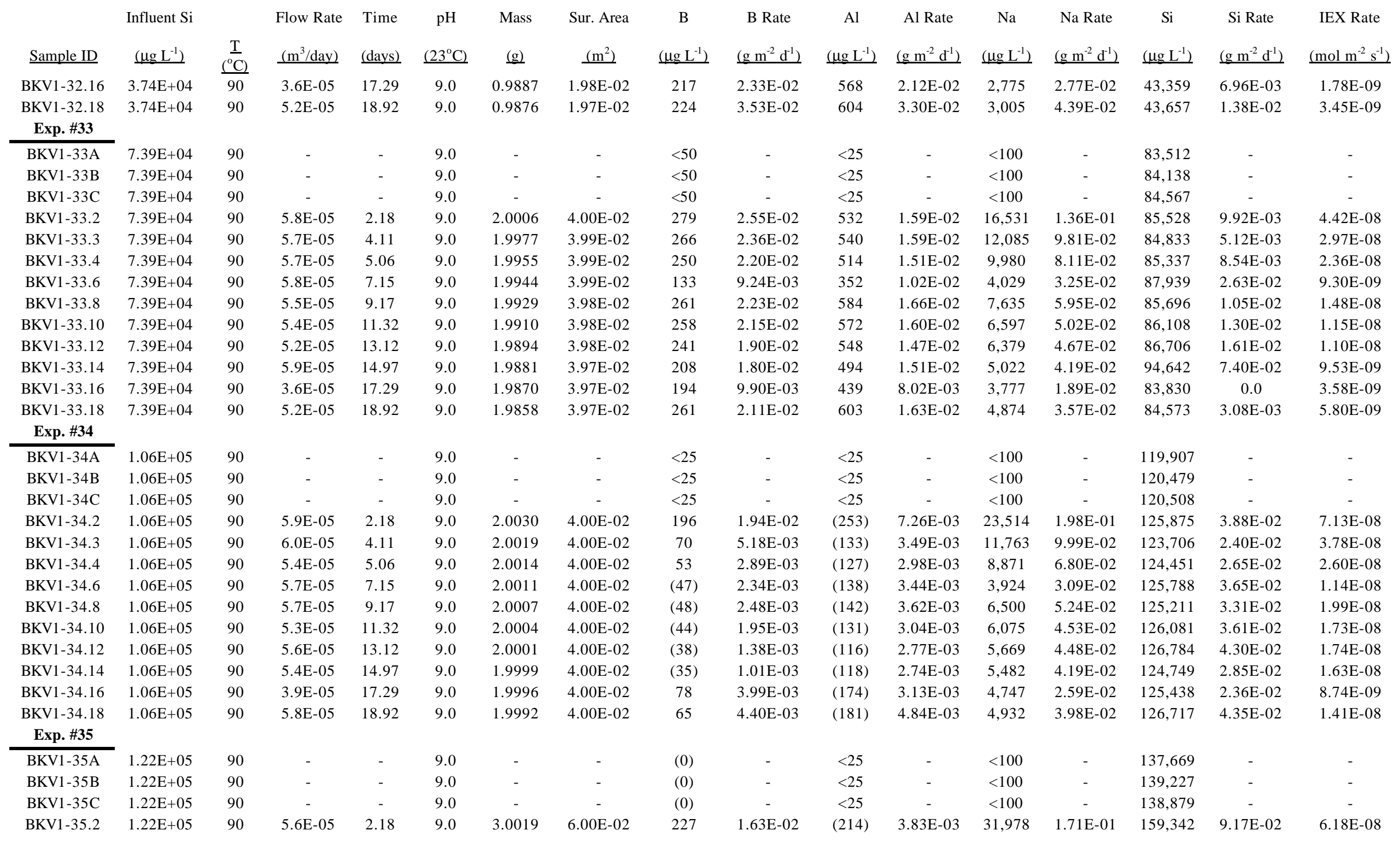


Table B1. SPFT Temperature Sweep, Experimental Conditions, and Dissolution Rates. Data in parenthesis are near quantification limit.

\begin{tabular}{|c|c|c|c|c|c|c|c|c|c|c|c|c|c|c|c|c|}
\hline & Influent $\mathrm{Si}$ & & Flow Rate & Time & $\mathrm{pH}$ & Mass & Sur. Area & B & B Rate & $\mathrm{Al}$ & Al Rate & $\mathrm{Na}$ & Na Rate & $\mathrm{Si}$ & Si Rate & IEX Rate \\
\hline$\underline{\text { Sample ID }}$ & $\underline{\left(\mu \mathrm{g} \mathrm{L}^{-1}\right)}$ & $\frac{\mathrm{T}}{\left({ }^{\circ} \mathrm{C}\right)}$ & $\underline{\left(\mathrm{m}^{3} / \mathrm{day}\right)}$ & $\underline{\text { (days) }}$ & $\underline{\left(23^{\circ} \mathrm{C}\right)}$ & $\underline{(\mathrm{g})}$ & $\underline{\left(\mathrm{m}^{2}\right)}$ & $\underline{\left(\mu \mathrm{g} \mathrm{L} \mathrm{L}^{-1}\right)}$ & $\underline{\left(\mathrm{g} \mathrm{m}^{-2} \mathrm{~d}^{-1}\right)}$ & $\underline{\left(\mu \mathrm{g} \mathrm{L}^{-1}\right)}$ & $\underline{\left(\mathrm{g} \mathrm{m}^{-2} \mathrm{~d}^{-1}\right)}$ & $\underline{\left(\mu \mathrm{g} \mathrm{L}^{-1}\right)}$ & $\underline{\left(\mathrm{g} \mathrm{m}^{-2} \mathrm{~d}^{-1}\right)}$ & $\left.\underline{(\mu \mathrm{g} \mathrm{L}} \mathrm{L}^{-1}\right)$ & $\underline{\left(\mathrm{g} \mathrm{m}^{-2} \mathrm{~d}^{-1}\right)}$ & $\underline{\left(\mathrm{mol} \mathrm{m} \mathrm{m}^{-2} \mathrm{~s}^{-1}\right)}$ \\
\hline BKV1-35.3 & $1.22 \mathrm{E}+05$ & 90 & $5.4 \mathrm{E}-05$ & 4.11 & 9.0 & 3.0007 & $6.00 \mathrm{E}-02$ & 79 & $5.41 \mathrm{E}-03$ & (94) & $1.32 \mathrm{E}-03$ & 17,227 & $8.75 \mathrm{E}-02$ & 158,040 & $8.18 \mathrm{E}-02$ & $3.28 \mathrm{E}-08$ \\
\hline BKV1-35.4 & $1.22 \mathrm{E}+05$ & 90 & $6.2 \mathrm{E}-05$ & 5.06 & 9.0 & 3.0002 & $6.00 \mathrm{E}-02$ & 52 & $4.08 \mathrm{E}-03$ & (79) & $1.19 \mathrm{E}-03$ & 13,622 & 7.94E-02 & 162,850 & $1.17 \mathrm{E}-01$ & $3.01 \mathrm{E}-08$ \\
\hline BKV1-35.6 & $1.22 \mathrm{E}+05$ & 90 & $5.8 \mathrm{E}-05$ & 7.15 & 9.0 & 3.0000 & $6.00 \mathrm{E}-02$ & (20) & $1.51 \mathrm{E}-03$ & (67) & $8.89 \mathrm{E}-04$ & 4,766 & $2.60 \mathrm{E}-02$ & 158,406 & $9.07 \mathrm{E}-02$ & $9.76 \mathrm{E}-09$ \\
\hline BKV1-35.8 & $1.22 \mathrm{E}+05$ & 90 & $5.3 \mathrm{E}-05$ & 9.17 & 9.0 & 2.9998 & $6.00 \mathrm{E}-02$ & (38) & $2.55 \mathrm{E}-03$ & (92) & $1.28 \mathrm{E}-03$ & 10,784 & $5.40 \mathrm{E}-02$ & 156,912 & $7.63 \mathrm{E}-02$ & $2.06 \mathrm{E}-08$ \\
\hline BKV1-35.10 & $1.22 \mathrm{E}+05$ & 90 & $5.6 \mathrm{E}-05$ & 11.32 & 9.0 & 2.9995 & $5.99 \mathrm{E}-02$ & (35) & $2.51 \mathrm{E}-03$ & (83) & $1.17 \mathrm{E}-03$ & 10,261 & $5.46 \mathrm{E}-02$ & 165,851 & $1.20 \mathrm{E}-01$ & $2.08 \mathrm{E}-08$ \\
\hline BKV1-35.12 & $1.22 \mathrm{E}+05$ & 90 & $5.0 \mathrm{E}-05$ & 13.12 & 9.0 & 2.9993 & $5.99 \mathrm{E}-02$ & (31) & $2.01 \mathrm{E}-03$ & $(78)$ & $9.57 \mathrm{E}-04$ & 9,271 & $4.41 \mathrm{E}-02$ & 165,734 & $1.07 \mathrm{E}-01$ & $1.68 \mathrm{E}-08$ \\
\hline BKV1-35.14 & $1.22 \mathrm{E}+05$ & 90 & $5.9 \mathrm{E}-05$ & 14.97 & 9.0 & 2.9991 & $5.99 \mathrm{E}-02$ & (26) & $1.98 \mathrm{E}-03$ & (75) & $1.06 \mathrm{E}-03$ & 8,350 & 4.62E-02 & 158,392 & $9.13 \mathrm{E}-02$ & $1.77 \mathrm{E}-08$ \\
\hline BKV1-35.16 & $1.22 \mathrm{E}+05$ & 90 & $3.7 \mathrm{E}-05$ & 17.29 & 9.0 & 2.9990 & $5.99 \mathrm{E}-02$ & (24) & $1.15 \mathrm{E}-03$ & (108) & $1.12 \mathrm{E}-03$ & 6,950 & $2.44 \mathrm{E}-02$ & 159,845 & $6.22 \mathrm{E}-02$ & $9.27 \mathrm{E}-09$ \\
\hline BKV1-35.18 & $1.22 \mathrm{E}+05$ & 90 & $5.7 \mathrm{E}-05$ & 18.92 & 9.0 & 2.9988 & $5.99 \mathrm{E}-02$ & (29) & $2.11 \mathrm{E}-03$ & (112) & $1.78 \mathrm{E}-03$ & 7,442 & 3.99E-02 & 164,269 & $1.15 \mathrm{E}-01$ & $1.51 \mathrm{E}-08$ \\
\hline \multicolumn{17}{|l|}{ Exp. \#36 } \\
\hline BKV1-36A & $1.39 \mathrm{E}+05$ & 90 & - & - & & - & - & (0) & - & $<25$ & - & $<100$ & - & 156,976 & - & - \\
\hline BKV1-36B & $1.39 \mathrm{E}+05$ & 90 & - & - & & - & - & $(0)$ & - & $<25$ & - & $<100$ & - & 157,718 & - & - \\
\hline BKV1-36C & $1.39 \mathrm{E}+05$ & 90 & - & - & & - & - & $(0)$ & - & $<25$ & - & $<100$ & - & 159,423 & - & - \\
\hline BKV1-36.2 & $1.39 \mathrm{E}+05$ & 90 & $5.6 \mathrm{E}-05$ & 2.18 & 9.0 & 3.0054 & $4.16 \mathrm{E}-02$ & 121 & $1.25 \mathrm{E}-02$ & (101) & $2.21 \mathrm{E}-03$ & 23,409 & $1.79 \mathrm{E}-01$ & 179,183 & $1.34 \mathrm{E}-01$ & $6.66 \mathrm{E}-08$ \\
\hline BKV1-36.3 & $1.39 \mathrm{E}+05$ & 90 & $5.3 \mathrm{E}-05$ & 4.11 & 9.0 & 3.0046 & $6.01 \mathrm{E}-02$ & 65 & 4.44E-03 & (62) & 7.17E-04 & 17,050 & $8.60 \mathrm{E}-02$ & 182,775 & $1.03 \mathrm{E}-01$ & $3.25 \mathrm{E}-08$ \\
\hline BKV1-36.4 & $1.39 \mathrm{E}+05$ & 90 & $6.4 \mathrm{E}-05$ & 5.06 & 9.0 & 3.0042 & $6.00 \mathrm{E}-02$ & (45) & $3.61 \mathrm{E}-03$ & $(52)$ & $6.16 \mathrm{E}-04$ & 13,902 & $8.36 \mathrm{E}-02$ & 178,614 & $1.03 \mathrm{E}-01$ & $3.19 \mathrm{E}-08$ \\
\hline BKV1-36.6 & $1.39 \mathrm{E}+05$ & 90 & $5.8 \mathrm{E}-05$ & 7.15 & 9.0 & 3.0039 & $6.00 \mathrm{E}-02$ & (26) & $1.91 \mathrm{E}-03$ & (91) & $1.39 \mathrm{E}-03$ & 5,686 & $3.10 \mathrm{E}-02$ & 192,192 & $1.56 \mathrm{E}-01$ & $1.16 \mathrm{E}-08$ \\
\hline BKV1-36.8 & $1.39 \mathrm{E}+05$ & 90 & $5.5 \mathrm{E}-05$ & 9.17 & 9.0 & 3.0037 & $6.00 \mathrm{E}-02$ & (30) & 2.09E-03 & (49) & $4.71 \mathrm{E}-04$ & 10,604 & $5.50 \mathrm{E}-02$ & 202,705 & $1.92 \mathrm{E}-01$ & $2.11 \mathrm{E}-08$ \\
\hline BKV1-36.10 & $1.39 \mathrm{E}+05$ & 90 & $5.7 \mathrm{E}-05$ & 11.32 & 9.0 & 3.0035 & $6.00 \mathrm{E}-02$ & (30) & $2.15 \mathrm{E}-03$ & (35) & $2.09 \mathrm{E}-04$ & 15,388 & $8.24 \mathrm{E}-02$ & 170,288 & $5.43 \mathrm{E}-02$ & $3.20 \mathrm{E}-08$ \\
\hline BKV1-36.12 & $1.39 \mathrm{E}+05$ & 90 & $5.5 \mathrm{E}-05$ & 13.12 & 9.0 & 3.0033 & $6.00 \mathrm{E}-02$ & (37) & $2.60 \mathrm{E}-03$ & (28) & $5.99 \mathrm{E}-05$ & 15,153 & $7.89 \mathrm{E}-02$ & 169,887 & $5.11 \mathrm{E}-02$ & $3.05 \mathrm{E}-08$ \\
\hline BKV1-36.14 & $1.39 \mathrm{E}+05$ & 90 & 4.9E-05 & 14.97 & 9.0 & 3.0031 & $6.00 \mathrm{E}-02$ & (32) & $2.01 \mathrm{E}-03$ & (22) & 0.00 & 12,287 & $5.64 \mathrm{E}-02$ & 176,962 & $7.21 \mathrm{E}-02$ & $2.17 \mathrm{E}-08$ \\
\hline BKV1-36.16 & $1.39 \mathrm{E}+05$ & 90 & $3.7 \mathrm{E}-05$ & 17.29 & 9.0 & 3.0030 & $6.00 \mathrm{E}-02$ & (24) & $1.12 \mathrm{E}-03$ & (32) & $9.61 \mathrm{E}-05$ & 6,362 & 2.19E-02 & 177,759 & $5.67 \mathrm{E}-02$ & $8.29 \mathrm{E}-09$ \\
\hline BKV1-36.18 & $1.39 \mathrm{E}+05$ & 90 & $5.2 \mathrm{E}-05$ & 18.92 & 9.0 & 3.0028 & $6.00 \mathrm{E}-02$ & (31) & $2.03 \mathrm{E}-03$ & (45) & $3.75 \mathrm{E}-04$ & 6,913 & $3.37 \mathrm{E}-02$ & 197,826 & $1.62 \mathrm{E}-01$ & $1.26 \mathrm{E}-08$ \\
\hline \multicolumn{17}{|l|}{ Exp. \#37 } \\
\hline BKV1-37A & $8.67 \mathrm{E}+02$ & 70 & - & - & 9.0 & - & - & $<100$ & - & $<10$ & - & $<500$ & - & $<1000$ & - & - \\
\hline BKV1-37B & $8.67 E+02$ & 70 & - & - & 9.0 & - & - & $<100$ & - & $<10$ & - & $<500$ & - & $<1000$ & - & - \\
\hline BKV1-37C & $8.67 \mathrm{E}+02$ & 70 & - & - & 9.0 & - & - & $<100$ & - & $<10$ & - & $<500$ & - & $<1000$ & - & - \\
\hline BKV1-37.1 & $8.67 \mathrm{E}+02$ & 70 & $3.8 \mathrm{E}-05$ & 1.00 & 9.0 & 0.5080 & $1.02 \mathrm{E}-02$ & (7) & 0.00 & (3) & 0.00 & (15) & 0.00 & (91) & 0.00 & $6.42 \mathrm{E}-09$ \\
\hline BKV1-37.2 & $8.67 \mathrm{E}+02$ & 70 & 4.1E-05 & 1.95 & 9.0 & 0.5070 & $1.01 \mathrm{E}-02$ & 326 & 7.02E-02 & 1,010 & $8.73 \mathrm{E}-02$ & 6,462 & $1.38 \mathrm{E}-01$ & 4,631 & $6.92 \mathrm{E}-02$ & $2.71 \mathrm{E}-08$ \\
\hline BKV1-37.3 & $8.67 \mathrm{E}+02$ & 70 & $3.8 \mathrm{E}-05$ & 3.18 & 9.0 & 0.5048 & $1.01 \mathrm{E}-02$ & 481 & $1.09 \mathrm{E}-01$ & 1,492 & $1.20 \mathrm{E}-01$ & 7,160 & $1.43 \mathrm{E}-01$ & 6,580 & $9.83 \mathrm{E}-02$ & $1.33 \mathrm{E}-08$ \\
\hline BKV1-37.4 & $8.67 \mathrm{E}+02$ & 70 & $4.0 \mathrm{E}-05$ & 3.92 & 9.0 & 0.5028 & $1.01 \mathrm{E}-02$ & 481 & $1.16 \mathrm{E}-01$ & 1,491 & $1.26 \mathrm{E}-01$ & 6,279 & $1.31 \mathrm{E}-01$ & 6,589 & $1.04 \mathrm{E}-01$ & $6.01 \mathrm{E}-09$ \\
\hline BKV1-37.5 & $8.67 \mathrm{E}+02$ & 70 & $3.1 \mathrm{E}-05$ & 5.10 & 9.0 & 0.5009 & $1.00 \mathrm{E}-02$ & 487 & $9.17 \mathrm{E}-02$ & 1,517 & $1.00 \mathrm{E}-01$ & 6,204 & $1.01 \mathrm{E}-01$ & 6,721 & 8.32E-02 & $3.60 \mathrm{E}-09$ \\
\hline BKV1-37.6 & $8.67 E+02$ & 70 & $3.9 \mathrm{E}-05$ & 6.01 & 9.0 & 0.4990 & $9.99 \mathrm{E}-03$ & 459 & $1.07 \mathrm{E}-01$ & 1,440 & $1.20 \mathrm{E}-01$ & 5,683 & $1.16 \mathrm{E}-01$ & 6,455 & $1.00 \mathrm{E}-01$ & $3.35 \mathrm{E}-09$ \\
\hline BKV1-37.7 & $8.67 \mathrm{E}+02$ & 70 & $3.9 \mathrm{E}-05$ & 6.94 & 9.0 & 0.4971 & $9.95 \mathrm{E}-03$ & 452 & $1.07 \mathrm{E}-01$ & 1,444 & $1.23 \mathrm{E}-01$ & 5,455 & $1.12 \mathrm{E}-01$ & 6,459 & $1.02 \mathrm{E}-01$ & 2.09E-09 \\
\hline BKV1-37.9 & $8.67 \mathrm{E}+02$ & 70 & $4.0 \mathrm{E}-05$ & 8.77 & 9.0 & 0.4952 & $9.91 \mathrm{E}-03$ & 452 & $1.08 \mathrm{E}-01$ & 1,449 & $1.24 \mathrm{E}-01$ & 5,290 & $1.09 \mathrm{E}-01$ & 6,505 & $1.03 \mathrm{E}-01$ & $6.22 \mathrm{E}-10$ \\
\hline BKV1-37.11 & $8.67 \mathrm{E}+02$ & 70 & $4.0 \mathrm{E}-05$ & 11.16 & 9.0 & 0.4929 & $9.87 \mathrm{E}-03$ & 467 & $1.14 \mathrm{E}-01$ & 1,519 & $1.32 \mathrm{E}-01$ & 5,245 & $1.10 \mathrm{E}-01$ & 6,819 & $1.11 \mathrm{E}-01$ & 0.00 \\
\hline
\end{tabular}


Table B1. SPFT Temperature Sweep, Experimental Conditions, and Dissolution Rates. Data in parenthesis are near quantification limit.

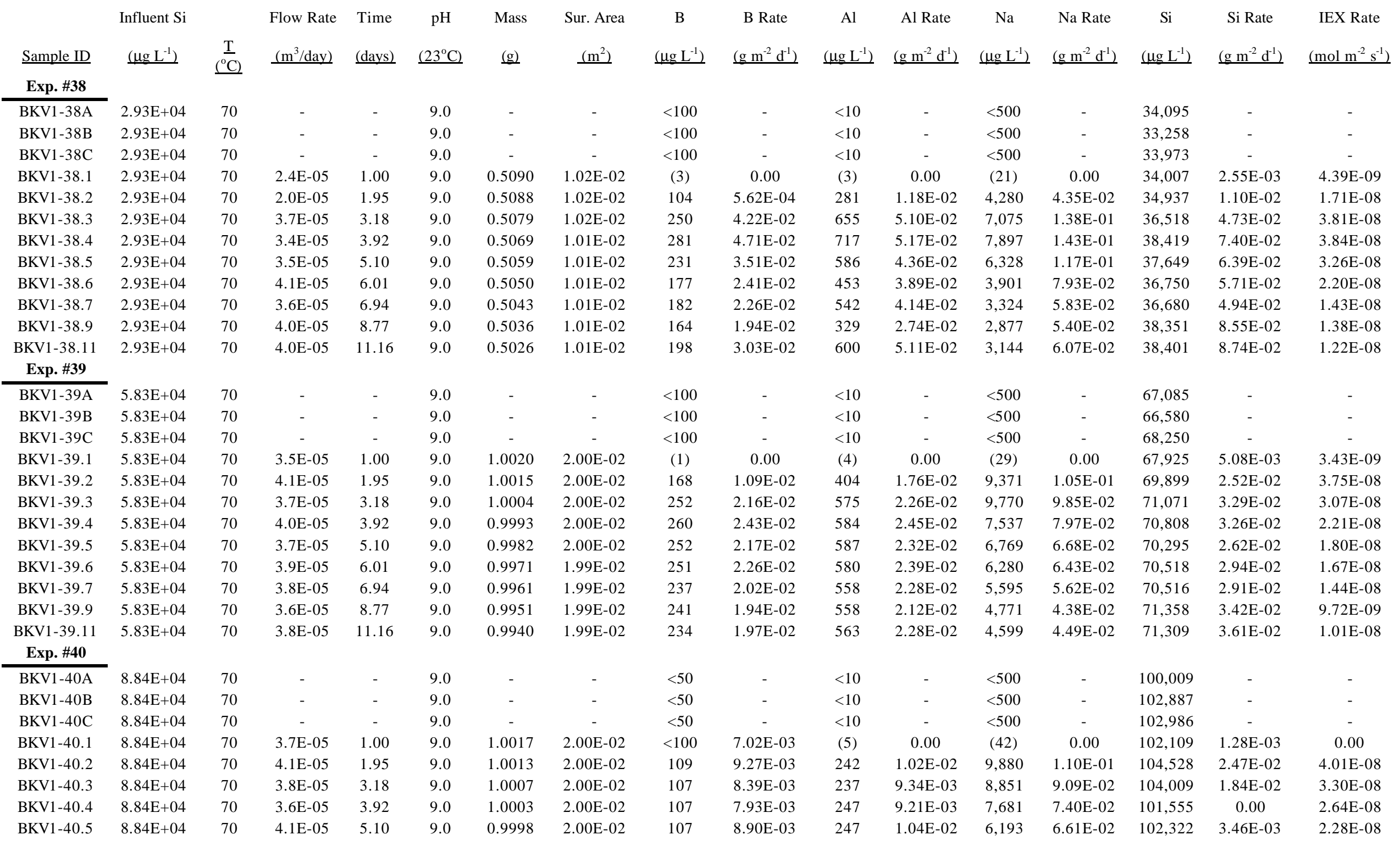


Table B1. SPFT Temperature Sweep, Experimental Conditions, and Dissolution Rates. Data in parenthesis are near quantification limit.

\begin{tabular}{|c|c|c|c|c|c|c|c|c|c|c|c|c|c|c|c|c|}
\hline & Influent $\mathrm{Si}$ & & Flow Rate & Time & $\mathrm{pH}$ & Mass & Sur. Area & B & B Rate & $\mathrm{Al}$ & Al Rate & $\mathrm{Na}$ & Na Rate & $\mathrm{Si}$ & Si Rate & IEX Rate \\
\hline$\underline{\text { Sample ID }}$ & $\underline{\left(\mu g \mathrm{~L}^{-1}\right)}$ & $\frac{\mathrm{T}}{\left({ }^{\circ} \mathrm{C}\right)}$ & $\left(\mathrm{m}^{3} / \mathrm{day}\right)$ & $\underline{\text { (days) }}$ & $\underline{\left(23^{\circ} \mathrm{C}\right)}$ & $\underline{(\mathrm{g})}$ & $\left(\mathrm{m}^{2}\right)$ & $\underline{\left(\mu g \mathrm{~L}^{-1}\right)}$ & $\left(\mathrm{g} \mathrm{m}^{-2} \mathrm{~d}^{-1}\right)$ & $\underline{\left(\mu \mathrm{g} \mathrm{L}^{-1}\right)}$ & $\left(\mathrm{g} \mathrm{m}^{-2} \mathrm{~d}^{-1}\right)$ & $\underline{\left(\mu g \mathrm{~L}^{-1}\right)}$ & $\left(\mathrm{g} \mathrm{m}^{-2} \mathrm{~d}^{-1}\right)$ & $\underline{\left(\mu \mathrm{g} \mathrm{L}^{-1}\right)}$ & $\left(\mathrm{g} \mathrm{m}^{-2} \mathrm{~d}^{-1}\right)$ & $\left(\mathrm{mol} \mathrm{m}^{-2} \mathrm{~s}^{-1}\right)$ \\
\hline BKV1-40.6 & $8.84 \mathrm{E}+04$ & 70 & 3.7E-05 & 6.01 & 9.0 & 0.9993 & $2.00 \mathrm{E}-02$ & 102 & 7.37E-03 & 238 & 8.99E-03 & 5,689 & $5.44 \mathrm{E}-02$ & 102,558 & $5.15 \mathrm{E}-03$ & $1.88 \mathrm{E}-08$ \\
\hline BKV1-40.9 & $8.84 \mathrm{E}+04$ & 70 & $3.7 \mathrm{E}-05$ & 8.77 & 9.0 & 0.9986 & $2.00 \mathrm{E}-02$ & (86) & $5.04 \mathrm{E}-03$ & 246 & $9.33 \mathrm{E}-03$ & 5,146 & $4.87 \mathrm{E}-02$ & 104,978 & $2.60 \mathrm{E}-02$ & $1.74 \mathrm{E}-08$ \\
\hline $\begin{array}{l}\text { BKV1-40.11 } \\
\text { Exp. \#41 }\end{array}$ & $8.84 \mathrm{E}+04$ & 70 & 4.1E-05 & 11.16 & 9.0 & 0.9982 & $2.00 \mathrm{E}-02$ & (70) & $3.18 \mathrm{E}-03$ & 208 & 8.69E-03 & 4,536 & 4.69E-02 & 106,570 & $4.41 \mathrm{E}-02$ & $1.75 \mathrm{E}-08$ \\
\hline BKV1-41A & $1.14 \mathrm{E}+05$ & 70 & - & - & 9.0 & - & - & (9) & - & $<10$ & - & $<500$ & - & 132,990 & - & - \\
\hline BKV1-41B & $1.14 \mathrm{E}+05$ & 70 & - & - & 9.0 & - & - & (1) & - & $<10$ & - & $<500$ & - & 130,337 & - & - \\
\hline BKV1-41C & $1.14 \mathrm{E}+05$ & 70 & - & - & 9.0 & - & - & (0) & - & $<10$ & - & $<500$ & - & 130,548 & - & - \\
\hline BKV1-41.1 & $1.14 \mathrm{E}+05$ & 70 & $3.1 \mathrm{E}-05$ & 1.00 & 9.0 & 1.0038 & $2.01 \mathrm{E}-02$ & $<100$ & $1.16 \mathrm{E}-02$ & (6) & 0.00 & (42) & 0.00 & 146,258 & $1.10 \mathrm{E}-01$ & 0.00 \\
\hline BKV1-41.2 & $1.14 \mathrm{E}+05$ & 70 & $3.9 \mathrm{E}-05$ & 1.95 & 9.0 & 1.0034 & $2.01 \mathrm{E}-02$ & $(80)$ & $1.14 \mathrm{E}-02$ & 135 & $5.25 \mathrm{E}-03$ & 10,684 & $1.13 \mathrm{E}-01$ & 147,091 & $1.44 \mathrm{E}-01$ & $4.06 \mathrm{E}-08$ \\
\hline BKV1-41.3 & $1.14 \mathrm{E}+05$ & 70 & $3.8 \mathrm{E}-05$ & 3.18 & 9.0 & 1.0031 & $2.00 \mathrm{E}-02$ & (58) & $7.88 \mathrm{E}-03$ & 113 & $4.16 \mathrm{E}-03$ & 9,859 & $1.00 \mathrm{E}-01$ & 139,737 & $7.44 \mathrm{E}-02$ & $3.68 \mathrm{E}-08$ \\
\hline BKV1-41.4 & $1.14 \mathrm{E}+05$ & 70 & $4.0 \mathrm{E}-05$ & 3.92 & 9.0 & 1.0029 & $2.00 \mathrm{E}-02$ & (46) & $6.52 \mathrm{E}-03$ & 118 & $4.71 \mathrm{E}-03$ & 7,682 & $8.28 \mathrm{E}-02$ & 129,251 & 0.00 & $3.04 \mathrm{E}-08$ \\
\hline BKV1-41.5 & $1.14 \mathrm{E}+05$ & 70 & $3.8 \mathrm{E}-05$ & 5.10 & 9.0 & 1.0027 & $2.00 \mathrm{E}-02$ & (47) & $6.28 \mathrm{E}-03$ & 131 & 4.93E-03 & 6,609 & $6.57 \mathrm{E}-02$ & 126,650 & 0.00 & $2.37 \mathrm{E}-08$ \\
\hline BKV1-41.6 & $1.14 \mathrm{E}+05$ & 70 & $3.7 \mathrm{E}-05$ & 6.01 & 9.0 & 1.0025 & $2.00 \mathrm{E}-02$ & (47) & $6.12 \mathrm{E}-03$ & 126 & $4.60 \mathrm{E}-03$ & 5,617 & $5.36 \mathrm{E}-02$ & 126,804 & 0.00 & $1.89 \mathrm{E}-08$ \\
\hline BKV1-41.7 & $1.14 \mathrm{E}+05$ & 70 & $4.1 \mathrm{E}-05$ & 6.94 & 9.0 & 1.0023 & $2.00 \mathrm{E}-02$ & (44) & $6.25 \mathrm{E}-03$ & 117 & $4.69 \mathrm{E}-03$ & 5,168 & $5.42 \mathrm{E}-02$ & 126,557 & 0.00 & $1.91 \mathrm{E}-08$ \\
\hline $\begin{array}{c}\text { BKV1-41.11 } \\
\text { Exp. \#42 }\end{array}$ & $1.14 \mathrm{E}+05$ & 70 & $3.7 \mathrm{E}-05$ & 11.16 & 9.0 & 1.0021 & $2.00 \mathrm{E}-02$ & (8) & 7.17E-04 & 74 & $2.54 \mathrm{E}-03$ & 4,241 & $3.96 \mathrm{E}-02$ & 132,154 & $7.51 \mathrm{E}-03$ & $1.55 \mathrm{E}-08$ \\
\hline BKV1-42A & $1.37 \mathrm{E}+05$ & 70 & - & - & 9.0 & - & - & (8) & - & $<10$ & - & $<500$ & - & 156,518 & - & - \\
\hline BKV1-42B & $1.37 \mathrm{E}+05$ & 70 & - & - & 9.0 & - & - & (0) & - & $<10$ & - & $<500$ & - & 158,780 & - & - \\
\hline BKV1-42C & $1.37 \mathrm{E}+05$ & 70 & - & - & 9.0 & - & - & (0) & - & $<10$ & - & $<500$ & - & 158,768 & - & - \\
\hline BKV1-42.1 & $1.37 \mathrm{E}+05$ & 70 & $3.5 \mathrm{E}-05$ & 1.00 & 9.0 & 1.2997 & $2.60 \mathrm{E}-02$ & $<100$ & $1.02 \mathrm{E}-02$ & (5) & 0.00 & $(48)$ & 0.00 & 173,454 & $9.87 \mathrm{E}-02$ & 0.00 \\
\hline BKV1-42.2 & $1.37 \mathrm{E}+05$ & 70 & $3.6 \mathrm{E}-05$ & 1.95 & 9.0 & 1.2993 & $2.60 \mathrm{E}-02$ & (98) & $1.01 \mathrm{E}-02$ & 150 & $4.13 \mathrm{E}-03$ & 12,016 & $9.02 \mathrm{E}-02$ & 177,531 & $1.26 \mathrm{E}-01$ & $3.20 \mathrm{E}-08$ \\
\hline BKV1-42.3 & $1.37 \mathrm{E}+05$ & 70 & $3.9 \mathrm{E}-05$ & 3.18 & 9.0 & 1.2990 & $2.60 \mathrm{E}-02$ & (60) & $6.64 \mathrm{E}-03$ & 96 & $2.77 \mathrm{E}-03$ & 11,578 & $9.48 \mathrm{E}-02$ & 170,672 & $8.91 \mathrm{E}-02$ & $3.52 \mathrm{E}-08$ \\
\hline BKV1-42.4 & $1.37 \mathrm{E}+05$ & 70 & $3.3 \mathrm{E}-05$ & 3.92 & 9.0 & 1.2988 & $2.60 \mathrm{E}-02$ & (37) & $3.41 \mathrm{E}-03$ & 83 & $2.04 \mathrm{E}-03$ & 9,173 & $6.40 \mathrm{E}-02$ & 163,540 & $3.35 \mathrm{E}-02$ & $2.42 \mathrm{E}-08$ \\
\hline BKV1-42.5 & $1.37 \mathrm{E}+05$ & 70 & $3.9 \mathrm{E}-05$ & 5.10 & 9.0 & 1.2987 & $2.60 \mathrm{E}-02$ & (26) & $2.66 \mathrm{E}-03$ & 73 & $2.03 \mathrm{E}-03$ & 7,534 & $6.00 \mathrm{E}-02$ & 161,325 & $2.32 \mathrm{E}-02$ & $2.29 \mathrm{E}-08$ \\
\hline BKV1-42.6 & $1.37 \mathrm{E}+05$ & 70 & $3.5 \mathrm{E}-05$ & 6.01 & 9.0 & 1.2986 & $2.60 \mathrm{E}-02$ & (20) & $1.76 \mathrm{E}-03$ & 67 & $1.64 \mathrm{E}-03$ & 6,550 & 4.63E-02 & 156,218 & 0.00 & $1.78 \mathrm{E}-08$ \\
\hline BKV1-42.7 & $1.37 \mathrm{E}+05$ & 70 & $3.9 \mathrm{E}-05$ & 6.94 & 9.0 & 1.2985 & $2.60 \mathrm{E}-02$ & (20) & $2.05 \mathrm{E}-03$ & 79 & $2.27 \mathrm{E}-03$ & 5,919 & $4.71 \mathrm{E}-02$ & 149,299 & 0.00 & $1.80 \mathrm{E}-08$ \\
\hline BKV1-42.9 & $1.37 \mathrm{E}+05$ & 70 & $3.7 \mathrm{E}-05$ & 8.77 & 9.0 & 1.2985 & $2.60 \mathrm{E}-02$ & (10) & $8.71 \mathrm{E}-04$ & 71 & $1.87 \mathrm{E}-03$ & 5,689 & 4.24E-02 & 146,351 & 0.00 & $1.66 \mathrm{E}-08$ \\
\hline $\begin{array}{l}\text { BKV1-42.11 } \\
\text { Exp. \#43 }\end{array}$ & $1.37 \mathrm{E}+05$ & 70 & $9.8 \mathrm{E}-06$ & 11.16 & 9.0 & 1.2984 & $2.59 \mathrm{E}-02$ & (14) & $3.23 \mathrm{E}-04$ & 87 & $6.26 \mathrm{E}-04$ & 6,663 & $1.33 \mathrm{E}-02$ & 152,294 & 0.00 & $5.17 \mathrm{E}-09$ \\
\hline BKV1-43A & - & 70 & - & - & 7.0 & - & - & $<50$ & - & $<10$ & - & $<500$ & - & (182) & - & - \\
\hline
\end{tabular}


Table B1. SPFT Temperature Sweep, Experimental Conditions, and Dissolution Rates. Data in parenthesis are near quantification limit.

\begin{tabular}{|c|c|c|c|c|c|c|c|c|c|c|c|c|c|c|c|c|}
\hline & Influent $\mathrm{Si}$ & & Flow Rate & Time & $\mathrm{pH}$ & Mass & Sur. Area & B & B Rate & $\mathrm{Al}$ & Al Rate & $\mathrm{Na}$ & Na Rate & $\mathrm{Si}$ & Si Rate & IEX Rate \\
\hline$\underline{\text { Sample ID }}$ & $\underline{\left(\mu g \mathrm{~L}^{-1}\right)}$ & $\frac{\mathrm{T}}{\left({ }^{\circ} \mathrm{C}\right)}$ & $\left(\mathrm{m}^{3} / \mathrm{day}\right)$ & $\underline{\text { (days) }}$ & $\underline{\left(23^{\circ} \mathrm{C}\right)}$ & $\underline{(\mathrm{g})}$ & $\left(\mathrm{m}^{2}\right)$ & $\underline{\left(\mu g \mathrm{~L}^{-1}\right)}$ & $\underline{\left(\mathrm{g} \mathrm{m}^{-2} \mathrm{~d}^{-1}\right)}$ & $\underline{\left(\mu g \mathrm{~L}^{-1}\right)}$ & $\underline{\left(\mathrm{g} \mathrm{m}^{-2} \mathrm{~d}^{-1}\right)}$ & $\underline{\left(\mu g \mathrm{~L}^{-1}\right)}$ & $\underline{\left(\mathrm{g} \mathrm{m}^{-2} \mathrm{~d}^{-1}\right)}$ & $\underline{\left(\mu g \mathrm{~L}^{-1}\right)}$ & $\underline{\left(\mathrm{g} \mathrm{m}^{-2} \mathrm{~d}^{-1}\right)}$ & $\underline{\left(\mathrm{mol} \mathrm{m}^{-2} \mathrm{~s}^{-1}\right)}$ \\
\hline BKV1-43.2 & - & 70 & $4.0 \mathrm{E}-05$ & 2.20 & 7.0 & 1.0044 & $2.01 \mathrm{E}-02$ & 157 & $1.62 \mathrm{E}-02$ & 56 & $1.97 \mathrm{E}-03$ & 12,910 & $1.41 \mathrm{E}-01$ & (704) & $5.42 \mathrm{E}-03$ & $4.97 \mathrm{E}-08$ \\
\hline BKV1-43.4 & - & 70 & $3.8 \mathrm{E}-05$ & 4.12 & 7.0 & 1.0034 & $2.01 \mathrm{E}-02$ & 103 & $7.80 \mathrm{E}-03$ & 55 & $1.85 \mathrm{E}-03$ & 7,407 & $7.58 \mathrm{E}-02$ & (490) & $3.30 \mathrm{E}-03$ & $2.71 \mathrm{E}-08$ \\
\hline BKV1-43.5 & - & 70 & 4.0E-05 & 5.27 & 7.0 & 1.0030 & $2.00 \mathrm{E}-02$ & (90) & $6.06 \mathrm{E}-03$ & 60 & $2.13 \mathrm{E}-03$ & 6,299 & $6.55 \mathrm{E}-02$ & (438) & $2.92 \mathrm{E}-03$ & $2.37 \mathrm{E}-08$ \\
\hline BKV1-43.6 & - & 70 & $3.7 \mathrm{E}-05$ & 6.07 & 7.0 & 1.0026 & $2.00 \mathrm{E}-02$ & (79) & 4.10E-03 & 62 & 2.07E-03 & 5,484 & $5.23 \mathrm{E}-02$ & (401) & $2.39 \mathrm{E}-03$ & $1.92 \mathrm{E}-08$ \\
\hline BKV1-43.7 & - & 70 & $4.0 \mathrm{E}-05$ & 7.17 & 7.0 & 1.0023 & $2.00 \mathrm{E}-02$ & (73) & $3.53 \mathrm{E}-03$ & 62 & $2.23 \mathrm{E}-03$ & 5,036 & $5.17 \mathrm{E}-02$ & $(385)$ & $2.44 \mathrm{E}-03$ & $1.92 \mathrm{E}-08$ \\
\hline BKV1-43.9 & - & 70 & $4.0 \mathrm{E}-05$ & 8.87 & 7.0 & 1.0018 & $2.00 \mathrm{E}-02$ & (65) & $2.26 \mathrm{E}-03$ & 62 & $2.26 \mathrm{E}-03$ & 4,046 & $4.06 \mathrm{E}-02$ & (362) & $2.24 \mathrm{E}-03$ & $1.53 \mathrm{E}-08$ \\
\hline BKV1-43.11 & - & 70 & $4.0 \mathrm{E}-05$ & 10.93 & 7.0 & 1.0014 & $2.00 \mathrm{E}-02$ & (88) & $5.76 \mathrm{E}-03$ & 67 & $2.47 \mathrm{E}-03$ & 3,620 & $3.57 \mathrm{E}-02$ & (391) & $2.51 \mathrm{E}-03$ & $1.19 \mathrm{E}-08$ \\
\hline $\begin{array}{c}\text { BKV1-43.14 } \\
\text { Exp. \#44 }\end{array}$ & - & 70 & 4.1E-05 & 13.94 & 7.0 & 1.0011 & $2.00 \mathrm{E}-02$ & (76) & $4.05 \mathrm{E}-03$ & 54 & $1.91 \mathrm{E}-03$ & 3,055 & $2.96 \mathrm{E}-02$ & (384) & $2.47 \mathrm{E}-03$ & $1.02 \mathrm{E}-08$ \\
\hline BKV1-44A & - & 70 & - & - & 8.0 & - & - & $<100$ & - & $<10$ & - & $<500$ & - & $<1000$ & - & - \\
\hline BKV1-44B & - & 70 & - & - & 8.0 & - & - & $<100$ & - & 16 & - & $<500$ & - & $<1000$ & - & - \\
\hline BKV1-44C & - & 70 & - & - & 8.0 & - & - & $<100$ & - & 10 & - & $<500$ & - & $<1000$ & - & - \\
\hline BKV1-44.1 & - & 70 & 4.0E-05 & 1.19 & 8.0 & 1.0044 & $2.01 \mathrm{E}-02$ & 174 & $1.12 \mathrm{E}-02$ & 302 & $1.23 \mathrm{E}-02$ & 11,445 & $1.23 \mathrm{E}-01$ & 1,589 & $5.46 \mathrm{E}-03$ & $4.47 \mathrm{E}-08$ \\
\hline BKV1-44.3 & - & 70 & $3.9 \mathrm{E}-05$ & 3.02 & 8.0 & 1.0028 & $2.00 \mathrm{E}-02$ & 167 & $1.01 \mathrm{E}-02$ & 449 & $1.85 \mathrm{E}-02$ & 7,025 & $7.35 \mathrm{E}-02$ & 2,204 & $1.12 \mathrm{E}-02$ & $2.53 \mathrm{E}-08$ \\
\hline BKV1-44.4 & - & 70 & 4.1E-05 & 4.12 & 8.0 & 1.0021 & $2.00 \mathrm{E}-02$ & 160 & $9.31 \mathrm{E}-03$ & 447 & $1.90 \mathrm{E}-02$ & 5,661 & $5.98 \mathrm{E}-02$ & 2,170 & $1.12 \mathrm{E}-02$ & $2.02 \mathrm{E}-08$ \\
\hline BKV1-44.5 & - & 70 & $3.9 \mathrm{E}-05$ & 5.27 & 8.0 & 1.0012 & $2.00 \mathrm{E}-02$ & 157 & $8.47 \mathrm{E}-03$ & 411 & $1.67 \mathrm{E}-02$ & 4,373 & $4.29 \mathrm{E}-02$ & 2,171 & $1.07 \mathrm{E}-02$ & $1.38 \mathrm{E}-08$ \\
\hline BKV1-44.6 & - & 70 & 4.1E-05 & 6.07 & 8.0 & 1.0006 & $2.00 \mathrm{E}-02$ & 154 & $8.62 \mathrm{E}-03$ & 442 & $1.92 \mathrm{E}-02$ & 4,238 & $4.43 \mathrm{E}-02$ & 2,154 & $1.13 \mathrm{E}-02$ & $1.42 \mathrm{E}-08$ \\
\hline BKV1-44.7 & - & 70 & $3.9 \mathrm{E}-05$ & 7.17 & 8.0 & 0.9999 & $2.00 \mathrm{E}-02$ & 152 & $7.73 \mathrm{E}-03$ & 436 & $1.78 \mathrm{E}-02$ & 3,996 & $3.88 \mathrm{E}-02$ & 2,127 & $1.03 \mathrm{E}-02$ & $1.24 \mathrm{E}-08$ \\
\hline BKV1-44.8 & - & 70 & 4.2E-05 & 7.99 & 8.0 & 0.9992 & $2.00 \mathrm{E}-02$ & 151 & $8.31 \mathrm{E}-03$ & 419 & $1.85 \mathrm{E}-02$ & 3,712 & $3.88 \mathrm{E}-02$ & 2,161 & $1.15 \mathrm{E}-02$ & $1.22 \mathrm{E}-08$ \\
\hline BKV1-44.9 & - & 70 & $4.2 \mathrm{E}-05$ & 8.87 & 8.0 & 0.9986 & $2.00 \mathrm{E}-02$ & 149 & 7.77E-03 & 428 & $1.87 \mathrm{E}-02$ & 3,547 & $3.62 \mathrm{E}-02$ & 2,097 & $1.07 \mathrm{E}-02$ & $1.14 \mathrm{E}-08$ \\
\hline BKV1-44.11 & - & 70 & $4.1 \mathrm{E}-05$ & 10.93 & 8.0 & 0.9979 & $1.99 \mathrm{E}-02$ & 165 & $1.03 \mathrm{E}-02$ & 425 & $1.84 \mathrm{E}-02$ & 3,012 & $2.97 \mathrm{E}-02$ & 2,096 & $1.07 \mathrm{E}-02$ & 7.76E-09 \\
\hline $\begin{array}{c}\text { BKV1-44.14 } \\
\text { Exp. \#45 }\end{array}$ & - & 70 & $4.2 \mathrm{E}-05$ & 13.94 & 8.0 & 0.9973 & $1.99 \mathrm{E}-02$ & 162 & $1.00 \mathrm{E}-02$ & 408 & $1.79 \mathrm{E}-02$ & 2,758 & $2.71 \mathrm{E}-02$ & 2,196 & $1.18 \mathrm{E}-02$ & $6.82 \mathrm{E}-09$ \\
\hline BKV1-45A & - & 70 & - & - & 9.0 & - & - & $<100$ & - & $<10$ & - & $<500$ & - & $<1000$ & - & - \\
\hline BKV1-45B & - & 70 & - & - & 9.0 & - & - & $<100$ & - & $<10$ & - & $<500$ & - & $<1000$ & - & - \\
\hline BKV1-45C & - & 70 & - & - & 9.0 & - & - & $<100$ & - & $<10$ & - & $<500$ & - & $<1000$ & - & - \\
\hline BKV1-45.1 & - & 70 & $4.1 \mathrm{E}-05$ & 1.19 & 9.0 & 1.0002 & $2.00 \mathrm{E}-02$ & 477 & 7.49E-02 & 1,423 & $6.29 \mathrm{E}-02$ & 8,565 & $1.00 \mathrm{E}-01$ & 6,049 & $5.83 \mathrm{E}-02$ & $1.02 \mathrm{E}-08$ \\
\hline BKV1-45.2 & - & 70 & $3.8 \mathrm{E}-05$ & 2.20 & 9.0 & 0.9974 & $2.00 \mathrm{E}-02$ & 648 & $9.57 \mathrm{E}-02$ & 1,910 & 7.93E-02 & 9,024 & $9.93 \mathrm{E}-02$ & 8,172 & $7.40 \mathrm{E}-02$ & $1.45 \mathrm{E}-09$ \\
\hline BKV1-45.3 & - & 70 & 4.1E-05 & 3.02 & 9.0 & 0.9948 & $1.99 \mathrm{E}-02$ & 650 & $1.02 \mathrm{E}-01$ & 1,919 & $8.49 \mathrm{E}-02$ & 8,163 & $9.57 \mathrm{E}-02$ & 8,191 & 7.91E-02 & 0.00 \\
\hline BKV1-45.4 & - & 70 & $4.0 \mathrm{E}-05$ & 4.12 & 9.0 & 0.9917 & $1.98 \mathrm{E}-02$ & 651 & $1.01 \mathrm{E}-01$ & 1,920 & $8.38 \mathrm{E}-02$ & 7,750 & $8.96 \mathrm{E}-02$ & 8,300 & $7.90 \mathrm{E}-02$ & 0.00 \\
\hline BKV1-45.7 & - & 70 & $3.8 \mathrm{E}-05$ & 7.17 & 9.0 & 0.9831 & $1.97 \mathrm{E}-02$ & 608 & $9.07 \mathrm{E}-02$ & 1,824 & $7.66 \mathrm{E}-02$ & 6,843 & $7.61 \mathrm{E}-02$ & 7,838 & $7.18 \mathrm{E}-02$ & 0.00 \\
\hline
\end{tabular}


Table B1. SPFT Temperature Sweep, Experimental Conditions, and Dissolution Rates. Data in parenthesis are near quantification limit.

\begin{tabular}{|c|c|c|c|c|c|c|c|c|c|c|c|c|c|c|c|c|}
\hline & Influent $\mathrm{S}$ & & Flow Rate & Time & $\mathrm{pH}$ & Mass & Sur. Area & B & B Rate & $\mathrm{Al}$ & Al Rate & $\mathrm{Na}$ & Na Rate & $\mathrm{Si}$ & Si Rate & IEX Rate \\
\hline$\underline{\text { Sample ID }}$ & $\left.\underline{(\mu \mathrm{g} \mathrm{L}} \mathrm{L}^{-1}\right)$ & $\frac{\mathrm{T}}{\left({ }^{\circ} \mathrm{C}\right)}$ & $\left(\mathrm{m}^{3} / \mathrm{day}\right)$ & $\underline{\text { (days) }}$ & $\underline{\left(23^{\circ} \mathrm{C}\right)}$ & $\underline{(\mathrm{g})}$ & $\left(\mathrm{m}^{2}\right)$ & $\left.\underline{(\mu \mathrm{g} \mathrm{L}}{ }^{-1}\right)$ & $\underline{\left(\mathrm{g} \mathrm{m}^{-2} \mathrm{~d}^{-1}\right)}$ & $\left(\mu \mathrm{g} \mathrm{L} \mathrm{L}^{-1}\right)$ & $\left(\mathrm{g} \mathrm{m}^{-2} \mathrm{~d}^{-1}\right)$ & $\underline{\left(\mu \mathrm{g} \mathrm{L}^{-1}\right)}$ & $\underline{\left(\mathrm{g} \mathrm{m}^{-2} \mathrm{~d}^{-1}\right)}$ & $\left(\mu \mathrm{g} \mathrm{L} \mathrm{L}^{-1}\right)$ & $\left(\mathrm{g} \mathrm{m}^{-2} \mathrm{~d}^{-1}\right)$ & $\underline{\left(\mathrm{mol} \mathrm{m}^{-2} \mathrm{~s}^{-1}\right)}$ \\
\hline BKV1-45.8 & - & 70 & $4.2 \mathrm{E}-05$ & 7.99 & 9.0 & 0.9808 & $1.96 \mathrm{E}-02$ & 521 & $8.48 \mathrm{E}-02$ & 1,260 & $5.78 \mathrm{E}-02$ & 5,343 & $6.49 \mathrm{E}-02$ & 6,529 & $6.53 \mathrm{E}-02$ & 0.00 \\
\hline BKV1-45.9 & - & 70 & $3.9 \mathrm{E}-05$ & 8.87 & 9.0 & 0.9786 & $1.96 \mathrm{E}-02$ & 558 & $8.58 \mathrm{E}-02$ & 1,667 & $7.21 \mathrm{E}-02$ & 6,083 & $6.97 \mathrm{E}-02$ & 7,148 & $6.74 \mathrm{E}-02$ & 0.00 \\
\hline BKV1-45.11 & - & 70 & $4.1 \mathrm{E}-05$ & 10.93 & 9.0 & 0.9762 & $1.95 \mathrm{E}-02$ & 568 & $9.20 \mathrm{E}-02$ & 1,361 & $6.21 \mathrm{E}-02$ & 5,674 & $6.86 \mathrm{E}-02$ & 7,193 & $7.16 \mathrm{E}-02$ & 0.00 \\
\hline BKV1-45.14 & - & 70 & $3.7 \mathrm{E}-05$ & 13.94 & 9.0 & 0.9743 & $1.95 \mathrm{E}-02$ & 586 & $8.55 \mathrm{E}-02$ & 1,745 & 7.17E-02 & 6,206 & $6.75 \mathrm{E}-02$ & 7,600 & $6.81 \mathrm{E}-02$ & 0.00 \\
\hline
\end{tabular}

Centerline

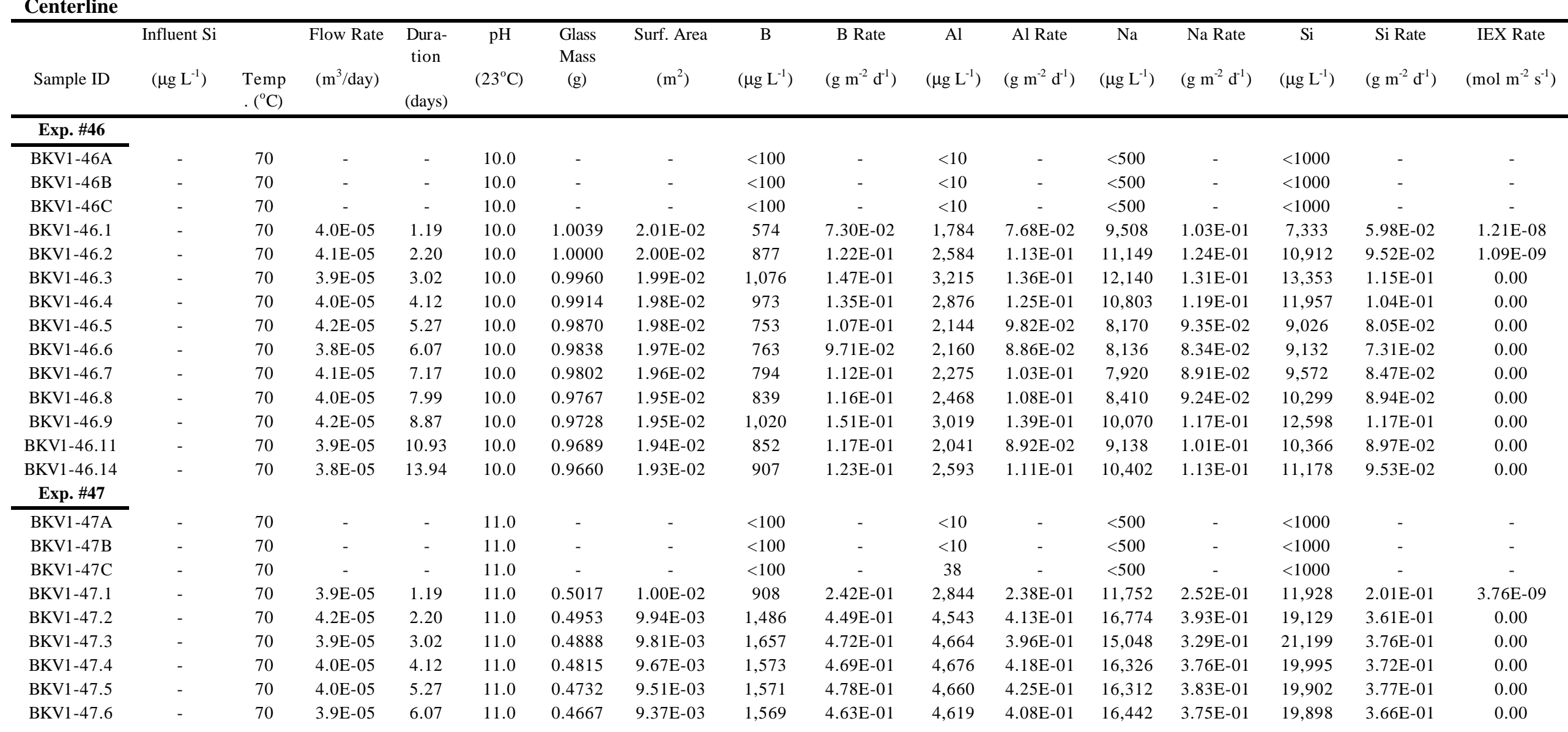


Table B1. SPFT Temperature Sweep, Experimental Conditions, and Dissolution Rates. Data in parenthesis are near quantification limit.

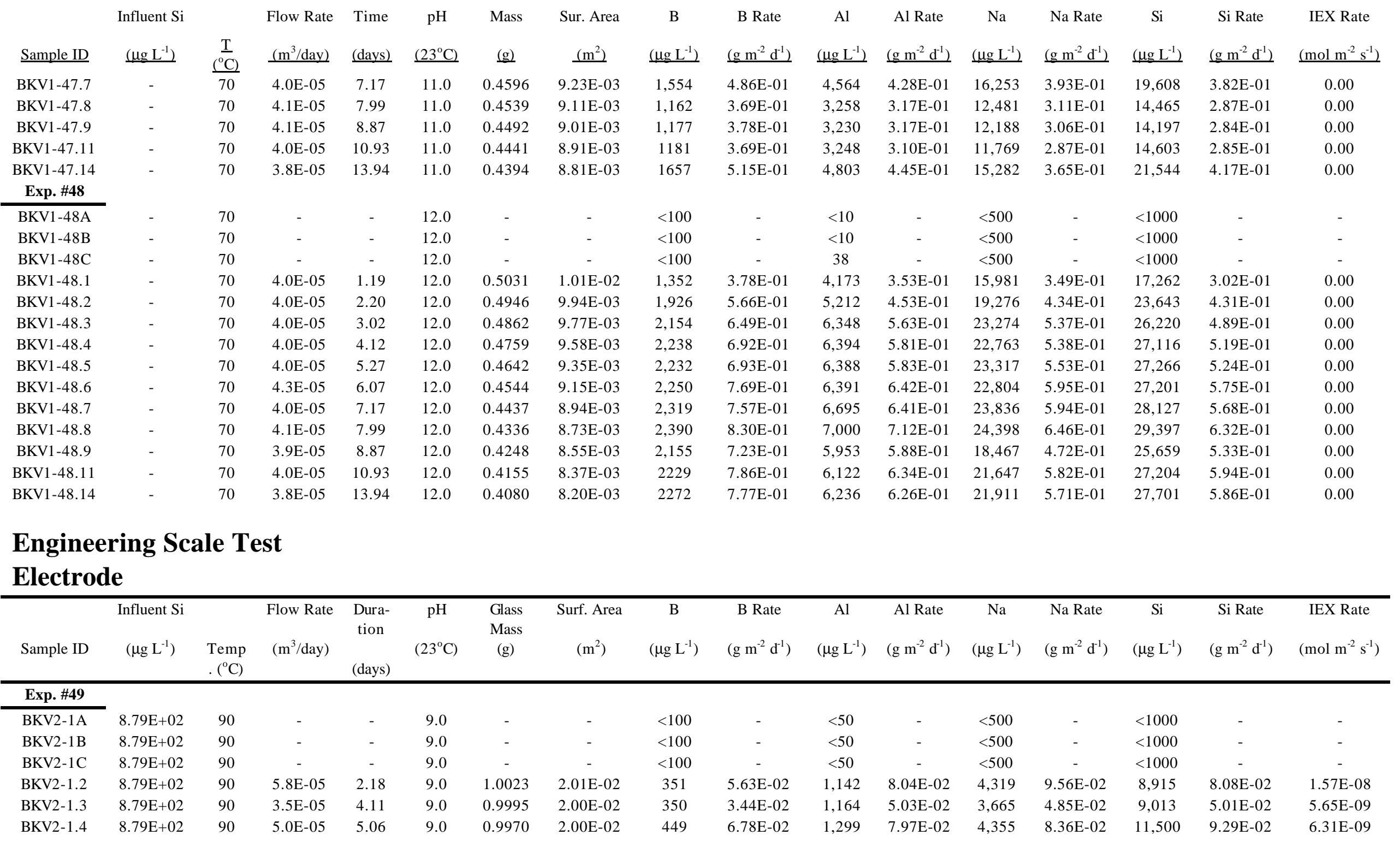


Table B1. SPFT Temperature Sweep, Experimental Conditions, and Dissolution Rates. Data in parenthesis are near quantification limit.

\begin{tabular}{|c|c|c|c|c|c|c|c|c|c|c|c|c|c|c|c|c|}
\hline & Influent Si & & Flow Rate & Time & $\mathrm{pH}$ & Mass & Sur. Area & B & B Rate & $\mathrm{Al}$ & Al Rate & $\mathrm{Na}$ & Na Rate & $\mathrm{Si}$ & Si Rate & IEX Rate \\
\hline$\underline{\text { Sample ID }}$ & $\underline{\left(\mu \mathrm{g} \mathrm{L}^{-1}\right)}$ & $\frac{\mathrm{T}}{\left({ }^{\circ} \mathrm{C}\right)}$ & $\left(\mathrm{m}^{3} / \mathrm{day}\right)$ & $\underline{\text { (days) }}$ & $\underline{\left(23^{\circ} \mathrm{C}\right)}$ & $\underline{(\mathrm{g})}$ & $\left(\mathrm{m}^{2}\right)$ & $\underline{\left(\mu g \mathrm{~L}^{-1}\right)}$ & $\underline{\left(\mathrm{g} \mathrm{m}^{-2} \mathrm{~d}^{-1}\right)}$ & $\left(\mu \mathrm{g} \mathrm{L}^{-1}\right)$ & $\underline{\left(\mathrm{g} \mathrm{m}^{-2} \mathrm{~d}^{-1}\right)}$ & $\underline{\left(\mu g \mathrm{~L}^{-1}\right)}$ & $\underline{\left(\mathrm{g} \mathrm{m}^{-2} \mathrm{~d}^{-1}\right)}$ & $\left(\mu \mathrm{g} \mathrm{L}^{-1}\right)$ & $\left(\mathrm{g} \mathrm{m}^{-2} \mathrm{~d}^{-1}\right)$ & $\left(\mathrm{mol} \mathrm{m} \mathrm{m}^{-2} \mathrm{~s}^{-1}\right)$ \\
\hline BKV2-1.6 & $8.79 \mathrm{E}+02$ & 90 & $5.9 \mathrm{E}-05$ & 7.14 & 9.0 & 0.9941 & $1.99 \mathrm{E}-02$ & 397 & $6.82 \mathrm{E}-02$ & 1,295 & $9.40 \mathrm{E}-02$ & 3,532 & $7.78 \mathrm{E}-02$ & 10,247 & $9.68 \mathrm{E}-02$ & $3.81 \mathrm{E}-09$ \\
\hline BKV2-1.8 & $8.79 \mathrm{E}+02$ & 90 & $5.3 \mathrm{E}-05$ & 9.17 & 9.0 & 0.9915 & $1.98 \mathrm{E}-02$ & 386 & $5.92 \mathrm{E}-02$ & 1,208 & $7.88 \mathrm{E}-02$ & 3,795 & $7.62 \mathrm{E}-02$ & 9,986 & $8.48 \mathrm{E}-02$ & $6.78 \mathrm{E}-09$ \\
\hline BKV2-1.10 & $8.79 \mathrm{E}+02$ & 90 & $5.6 \mathrm{E}-05$ & 11.32 & 9.0 & 0.9886 & $1.98 \mathrm{E}-02$ & 383 & $6.22 \mathrm{E}-02$ & 1,230 & $8.52 \mathrm{E}-02$ & 3,784 & $8.06 \mathrm{E}-02$ & 10,139 & $9.15 \mathrm{E}-02$ & $7.35 \mathrm{E}-09$ \\
\hline BKV2-1.12 & $8.79 \mathrm{E}+02$ & 90 & $4.0 \mathrm{E}-05$ & 13.12 & 9.0 & 0.9864 & $1.97 \mathrm{E}-02$ & 385 & $4.46 \mathrm{E}-02$ & 1,294 & $6.40 \mathrm{E}-02$ & 3,738 & $5.66 \mathrm{E}-02$ & 10,473 & $6.75 \mathrm{E}-02$ & 4.79E-09 \\
\hline BKV2-1.14 & $8.79 \mathrm{E}+02$ & 90 & $5.6 \mathrm{E}-05$ & 14.97 & 9.0 & 0.9843 & $1.97 \mathrm{E}-02$ & 391 & $6.43 \mathrm{E}-02$ & 1,283 & $8.96 \mathrm{E}-02$ & 3,421 & $7.22 \mathrm{E}-02$ & 10,346 & $9.42 \mathrm{E}-02$ & $3.15 \mathrm{E}-09$ \\
\hline BKV2-1.16 & $8.79 \mathrm{E}+02$ & 90 & $5.0 \mathrm{E}-05$ & 17.29 & 9.0 & 0.9816 & $1.96 \mathrm{E}-02$ & 413 & $6.18 \mathrm{E}-02$ & 712 & $4.30 \mathrm{E}-02$ & 4,064 & $7.87 \mathrm{E}-02$ & 11,183 & $9.17 \mathrm{E}-02$ & $6.72 \mathrm{E}-09$ \\
\hline
\end{tabular}

\section{Centerline}

\begin{tabular}{|c|c|c|c|c|c|c|c|c|c|c|c|c|c|c|c|c|}
\hline Exp. \#50 & & & & & & & & & & & & & & & & \\
\hline BKVX-1A & $8.82 \mathrm{E}+02$ & 40 & - & - & 9.0 & - & - & (0) & - & $<25$ & - & $<500$ & - & $<1000$ & - & - \\
\hline BKVX-1.1 & $8.82 \mathrm{E}+02$ & 40 & $9.5 \mathrm{E}-06$ & 1.16 & 9.0 & 1.0040 & $2.01 \mathrm{E}-02$ & (27) & 8.37E-04 & 55 & 3.89E-04 & 1,872 & $4.41 \mathrm{E}-03$ & $(461)$ & - & $1.43 \mathrm{E}-09$ \\
\hline BKVX-1.2 & $8.82 \mathrm{E}+02$ & 40 & $9.5 \mathrm{E}-06$ & 2.01 & 9.0 & 1.0040 & $2.01 \mathrm{E}-02$ & (33) & $1.04 \mathrm{E}-03$ & 101 & $9.82 \mathrm{E}-04$ & 2,208 & $5.51 \mathrm{E}-03$ & (817) & - & $1.78 \mathrm{E}-09$ \\
\hline BKVX-1.4 & $8.82 \mathrm{E}+02$ & 40 & $9.4 \mathrm{E}-06$ & 4.37 & 9.0 & 1.0039 & $2.01 \mathrm{E}-02$ & (32) & $9.90 \mathrm{E}-04$ & 141 & $1.47 \mathrm{E}-03$ & 1,885 & $4.39 \mathrm{E}-03$ & 1,054 & $9.60 \mathrm{E}-05$ & $1.36 \mathrm{E}-09$ \\
\hline BKVX-1.5 & $8.82 \mathrm{E}+02$ & 40 & $9.5 \mathrm{E}-06$ & 5.19 & 9.0 & 1.0039 & $2.01 \mathrm{E}-02$ & (29) & $9.10 \mathrm{E}-04$ & 129 & $1.33 \mathrm{E}-03$ & 1,629 & $3.63 \mathrm{E}-03$ & 1,001 & $2.42 \mathrm{E}-06$ & $1.09 \mathrm{E}-09$ \\
\hline BKVX-1.11 & $8.82 \mathrm{E}+02$ & 40 & $9.4 \mathrm{E}-06$ & 19.08 & 9.0 & 1.0038 & $2.01 \mathrm{E}-02$ & (39) & $1.18 \mathrm{E}-03$ & 102 & $9.71 \mathrm{E}-04$ & $(658)$ & $5.00 \mathrm{E}-04$ & $(815)$ & 0.00 & 0.00 \\
\hline BKVX-1.12 & $8.82 \mathrm{E}+02$ & 40 & $9.2 \mathrm{E}-06$ & 21.05 & 9.0 & 1.0037 & $2.01 \mathrm{E}-02$ & (34) & $1.04 \mathrm{E}-03$ & 103 & $9.68 \mathrm{E}-04$ & (609) & $3.42 \mathrm{E}-04$ & 791 & 0.00 & 0.00 \\
\hline BKVX-1.13 & $8.82 \mathrm{E}+02$ & 40 & $9.4 \mathrm{E}-06$ & 26.00 & 9.0 & 1.0036 & $2.01 \mathrm{E}-02$ & (32) & $9.74 \mathrm{E}-04$ & 101 & $9.61 \mathrm{E}-04$ & 588 & $2.77 \mathrm{E}-04$ & 793 & 0.00 & 0.00 \\
\hline $\begin{array}{c}\text { BKVX-1.14 } \\
\text { Exp. \#51 }\end{array}$ & $8.82 \mathrm{E}+02$ & 40 & $9.4 \mathrm{E}-06$ & 29.99 & 9.0 & 1.0035 & $2.01 \mathrm{E}-02$ & (31) & $9.44 \mathrm{E}-04$ & 85 & $7.60 \mathrm{E}-04$ & 545 & $1.42 \mathrm{E}-04$ & 924 & 0.00 & 0.00 \\
\hline BKVX-2A & $1.61 \mathrm{E}+04$ & 40 & - & - & 9.0 & - & - & (0) & - & $<25$ & - & $<500$ & - & 20,617 & - & - \\
\hline BKVX-2.1 & $1.61 \mathrm{E}+04$ & 40 & $1.1 \mathrm{E}-05$ & 1.16 & 9.0 & 1.0070 & $2.01 \mathrm{E}-02$ & (13) & $4.53 \mathrm{E}-04$ & 30 & $7.80 \mathrm{E}-05$ & 1,480 & $3.56 \mathrm{E}-03$ & 20,639 & $4.51 \mathrm{E}-05$ & $1.24 \mathrm{E}-09$ \\
\hline BKVX-2.2 & $1.61 \mathrm{E}+04$ & 40 & $9.8 \mathrm{E}-06$ & 2.01 & 9.0 & 1.0070 & $2.01 \mathrm{E}-02$ & (22) & $6.92 \mathrm{E}-04$ & 68 & $5.68 \mathrm{E}-04$ & 2,007 & $4.96 \mathrm{E}-03$ & 20,886 & $5.01 \mathrm{E}-04$ & $1.70 \mathrm{E}-09$ \\
\hline BKVX-2.3 & $1.61 \mathrm{E}+04$ & 40 & $9.3 \mathrm{E}-06$ & 3.25 & 9.0 & 1.0070 & $2.01 \mathrm{E}-02$ & (17) & $5.25 \mathrm{E}-04$ & 74 & $6.11 \mathrm{E}-04$ & 1,826 & 4.17E-03 & 21,079 & $8.21 \mathrm{E}-04$ & $1.45 \mathrm{E}-09$ \\
\hline BKVX-2.4 & $1.61 \mathrm{E}+04$ & 40 & $9.5 \mathrm{E}-06$ & 4.37 & 9.0 & 1.0069 & $2.01 \mathrm{E}-02$ & (15) & $4.65 \mathrm{E}-04$ & 77 & $6.65 \mathrm{E}-04$ & 1,651 & $3.68 \mathrm{E}-03$ & 20,828 & $3.81 \mathrm{E}-04$ & $1.29 \mathrm{E}-09$ \\
\hline BKVX-2.5 & $1.61 \mathrm{E}+04$ & 40 & $9.5 \mathrm{E}-06$ & 5.19 & 9.0 & 1.0069 & $2.01 \mathrm{E}-02$ & (12) & $3.84 \mathrm{E}-04$ & 75 & $6.46 \mathrm{E}-04$ & 1,448 & $3.05 \mathrm{E}-03$ & 20,887 & $4.90 \mathrm{E}-04$ & $1.06 \mathrm{E}-09$ \\
\hline BKVX-2.12 & $1.61 \mathrm{E}+04$ & 40 & $9.5 \mathrm{E}-06$ & 21.05 & 9.0 & 1.0069 & $2.01 \mathrm{E}-02$ & (16) & $4.81 \mathrm{E}-04$ & (16) & 0.00 & $(553)$ & $1.69 \mathrm{E}-04$ & 20874 & $4.64 \mathrm{E}-04$ & 0.00 \\
\hline BKVX-2.13 & $1.61 \mathrm{E}+04$ & 40 & $9.5 \mathrm{E}-06$ & 26.00 & 9.0 & 1.0068 & $2.01 \mathrm{E}-02$ & (15) & $4.73 \mathrm{E}-04$ & (15) & 0.00 & (494) & 0.00 & 21017 & $7.29 \mathrm{E}-04$ & 0.00 \\
\hline $\begin{array}{c}\text { BKVX-2.14 } \\
\text { Exp. \#52 }\end{array}$ & $1.61 \mathrm{E}+04$ & 40 & $9.7 \mathrm{E}-06$ & 29.99 & 9.0 & 1.0067 & $2.01 \mathrm{E}-02$ & (14) & $4.52 \mathrm{E}-04$ & (14) & 0.00 & (448) & 0.00 & 20917 & $5.52 \mathrm{E}-04$ & 0.00 \\
\hline BKVX-3A & $3.21 \mathrm{E}+04$ & 40 & - & - & 9.0 & - & - & $(0)$ & - & $<25$ & - & $<500$ & - & 37,332 & - & - \\
\hline BKVX-3.1 & $3.21 \mathrm{E}+04$ & 40 & $1.1 \mathrm{E}-05$ & 1.16 & 9.0 & 2.0040 & $4.01 \mathrm{E}-02$ & (18) & $3.23 \mathrm{E}-04$ & 28 & $2.15 \mathrm{E}-05$ & 1,672 & $2.13 \mathrm{E}-03$ & 38,151 & $8.41 \mathrm{E}-04$ & $7.19 \mathrm{E}-10$ \\
\hline BKVX-3.2 & $3.21 \mathrm{E}+04$ & 40 & $9.5 \mathrm{E}-06$ & 2.01 & 9.0 & 2.0040 & $4.01 \mathrm{E}-02$ & (26) & $4.09 \mathrm{E}-04$ & 56 & $1.96 \mathrm{E}-04$ & 2,444 & $3.13 \mathrm{E}-03$ & 38,072 & $6.76 \mathrm{E}-04$ & $1.09 \mathrm{E}-09$ \\
\hline
\end{tabular}


Table B1. SPFT Temperature Sweep, Experimental Conditions, and Dissolution Rates. Data in parenthesis are near quantification limit.

\begin{tabular}{|c|c|c|c|c|c|c|c|c|c|c|c|c|c|c|c|c|}
\hline & Influent Si & & Flow Rate & Time & $\mathrm{pH}$ & Mass & Sur. Area & B & B Rate & $\mathrm{Al}$ & Al Rate & $\mathrm{Na}$ & Na Rate & $\mathrm{Si}$ & Si Rate & IEX Rate \\
\hline$\underline{\text { Sample ID }}$ & $\underline{\left(\mu g L^{-1}\right)}$ & $\frac{\mathrm{T}}{\left({ }^{\circ} \mathrm{C}\right)}$ & $\underline{\left(\mathrm{m}^{3} / \mathrm{day}\right)}$ & $\underline{\text { (days) }}$ & $\underline{\left(23^{\circ} \mathrm{C}\right)}$ & $\underline{(\mathrm{g})}$ & $\underline{\left(\mathrm{m}^{2}\right)}$ & $\left.\underline{(\mu \mathrm{g} \mathrm{L}}{ }^{-1}\right)$ & $\underline{\left(\mathrm{g} \mathrm{m}^{-2} \mathrm{~d}^{-1}\right)}$ & $\underline{\left(\mu g \mathrm{~L}^{-1}\right)}$ & $\underline{\left(\mathrm{g} \mathrm{m}^{-2} \mathrm{~d}^{-1}\right)}$ & $\underline{\left(\mu g L^{-1}\right)}$ & $\left(\mathrm{g} \mathrm{m}^{-2} \mathrm{~d}^{-1}\right)$ & $\left(\mu g \mathrm{~L}^{-1}\right)$ & $\left(\mathrm{g} \mathrm{m}^{-2} \mathrm{~d}^{-1}\right)$ & $\left(\mathrm{mol} \mathrm{m} \mathrm{m}^{-2} \mathrm{~s}^{-1}\right)$ \\
\hline BKVX-3.3 & $3.21 \mathrm{E}+04$ & 40 & $9.5 \mathrm{E}-06$ & 3.25 & 9.0 & 2.0039 & $4.01 \mathrm{E}-02$ & (26) & $4.01 \mathrm{E}-04$ & 69 & $2.81 \mathrm{E}-04$ & 2,495 & $3.22 \mathrm{E}-03$ & 38,342 & $9.23 \mathrm{E}-04$ & $1.13 \mathrm{E}-09$ \\
\hline BKVX-3.4 & $3.21 \mathrm{E}+04$ & 40 & $9.5 \mathrm{E}-06$ & 4.37 & 9.0 & 2.0039 & $4.01 \mathrm{E}-02$ & (24) & $3.80 \mathrm{E}-04$ & 77 & $3.35 \mathrm{E}-04$ & 2,459 & $3.17 \mathrm{E}-03$ & 38,258 & $8.48 \mathrm{E}-04$ & $1.11 \mathrm{E}-09$ \\
\hline BKVX-3.5 & $3.21 \mathrm{E}+04$ & 40 & $9.6 \mathrm{E}-06$ & 5.19 & 9.0 & 2.0039 & $4.01 \mathrm{E}-02$ & (23) & $3.60 \mathrm{E}-04$ & 83 & $3.76 \mathrm{E}-04$ & 2,312 & $2.95 \mathrm{E}-03$ & 38,608 & $1.18 \mathrm{E}-03$ & $1.03 \mathrm{E}-09$ \\
\hline BKVX-3.11 & $3.21 \mathrm{E}+04$ & 40 & $9.6 \mathrm{E}-06$ & 19.08 & 9.0 & 2.0038 & $4.01 \mathrm{E}-02$ & (23) & $3.56 \mathrm{E}-04$ & 70 & $2.93 \mathrm{E}-04$ & 1209 & $1.15 \mathrm{E}-03$ & 39087 & $1.62 \mathrm{E}-03$ & $3.18 \mathrm{E}-10$ \\
\hline BKVX-3.12 & $3.21 \mathrm{E}+04$ & 40 & $9.6 \mathrm{E}-06$ & 21.05 & 9.0 & 2.0038 & $4.01 \mathrm{E}-02$ & (20) & $3.18 \mathrm{E}-04$ & 67 & $2.71 \mathrm{E}-04$ & 1096 & $9.68 \mathrm{E}-04$ & 38843 & $1.39 \mathrm{E}-03$ & $2.59 \mathrm{E}-10$ \\
\hline BKVX-3.13 & $3.21 \mathrm{E}+04$ & 40 & $9.6 \mathrm{E}-06$ & 26.00 & 9.0 & 2.0037 & $4.01 \mathrm{E}-02$ & (30) & $4.76 \mathrm{E}-04$ & 62 & $2.39 \mathrm{E}-04$ & $(942)$ & $7.17 \mathrm{E}-04$ & 37633 & $2.76 \mathrm{E}-04$ & $9.61 \mathrm{E}-11$ \\
\hline BKVX-4A & $4.78 \mathrm{E}+04$ & 40 & - & - & 9.0 & - & - & (0) & - & $<25$ & - & $<500$ & - & 54,985 & - & - \\
\hline BKVX-4.1 & $4.78 \mathrm{E}+04$ & 40 & $1.1 \mathrm{E}-05$ & 1.16 & 9.0 & 2.0020 & $4.00 \mathrm{E}-02$ & (37) & $6.49 \mathrm{E}-04$ & 51 & $1.86 \mathrm{E}-04$ & 3,230 & $4.96 \mathrm{E}-03$ & 55,708 & $7.43 \mathrm{E}-04$ & $1.72 \mathrm{E}-09$ \\
\hline BKVX-4.2 & $4.78 \mathrm{E}+04$ & 40 & $9.3 \mathrm{E}-06$ & 2.01 & 9.0 & 2.0019 & $4.00 \mathrm{E}-02$ & (67) & $1.02 \mathrm{E}-03$ & 75 & $3.14 \mathrm{E}-04$ & 3,998 & $5.55 \mathrm{E}-03$ & 56,062 & $9.67 \mathrm{E}-04$ & $1.81 \mathrm{E}-09$ \\
\hline BKVX-4.3 & $4.78 \mathrm{E}+04$ & 40 & $9.4 \mathrm{E}-06$ & 3.25 & 9.0 & 2.0019 & $4.00 \mathrm{E}-02$ & (46) & 7.09E-04 & 81 & $3.56 \mathrm{E}-04$ & 3,505 & $4.80 \mathrm{E}-03$ & 56,449 & $1.32 \mathrm{E}-03$ & $1.63 \mathrm{E}-09$ \\
\hline BKVX-4.4 & $4.78 \mathrm{E}+04$ & 40 & $9.5 \mathrm{E}-06$ & 4.37 & 9.0 & 2.0018 & $4.00 \mathrm{E}-02$ & (33) & $5.19 \mathrm{E}-04$ & 82 & $3.70 \mathrm{E}-04$ & 3,094 & $4.19 \mathrm{E}-03$ & 55,634 & $5.93 \mathrm{E}-04$ & $1.46 \mathrm{E}-09$ \\
\hline BKVX-4.5 & $4.78 \mathrm{E}+04$ & 40 & $9.6 \mathrm{E}-06$ & 5.19 & 9.0 & 2.0018 & $4.00 \mathrm{E}-02$ & (24) & $3.74 \mathrm{E}-04$ & 79 & $3.52 \mathrm{E}-04$ & 2,567 & $3.37 \mathrm{E}-03$ & 55,914 & $8.58 \mathrm{E}-04$ & $1.20 \mathrm{E}-09$ \\
\hline BKVX-4.11 & $4.78 \mathrm{E}+04$ & 40 & $9.6 \mathrm{E}-06$ & 19.08 & 9.0 & 2.0017 & $4.00 \mathrm{E}-02$ & (60) & $9.45 \mathrm{E}-04$ & 56 & 2.03E-04 & 925 & $6.92 \mathrm{E}-04$ & 54492 & 0.00 & 0.00 \\
\hline BKVX-4.13 & $4.78 \mathrm{E}+04$ & 40 & $9.2 \mathrm{E}-06$ & 26.00 & 9.0 & 2.0014 & $4.00 \mathrm{E}-02$ & (57) & $8.62 \mathrm{E}-04$ & 52 & $1.69 \mathrm{E}-04$ & 797 & $4.62 \mathrm{E}-04$ & 55003 & $1.60 \mathrm{E}-05$ & 0.00 \\
\hline $\begin{array}{c}\text { BKVX-4.14 } \\
\text { Exp. \#54 }\end{array}$ & $4.78 \mathrm{E}+04$ & 40 & $9.7 \mathrm{E}-06$ & 29.99 & 9.0 & 2.0011 & $4.00 \mathrm{E}-02$ & (56) & $8.95 \mathrm{E}-04$ & 48 & $1.51 \mathrm{E}-04$ & 699 & $3.26 \mathrm{E}-04$ & 54569 & 0.00 & 0.00 \\
\hline BKVX-5A & $6.89 \mathrm{E}+04$ & 40 & - & - & 9.0 & - & - & $(0)$ & - & $<25$ & - & $<500$ & - & 73,883 & - & - \\
\hline BKVX-5.1 & $6.89 \mathrm{E}+04$ & 40 & $1.0 \mathrm{E}-05$ & 1.16 & 9.0 & 3.0050 & $6.01 \mathrm{E}-02$ & (51) & $5.75 \mathrm{E}-04$ & 47 & $1.04 \mathrm{E}-04$ & 4,046 & $4.17 \mathrm{E}-03$ & 74,522 & $4.25 \mathrm{E}-04$ & 1.44E-09 \\
\hline BKVX-5.2 & $6.89 \mathrm{E}+04$ & 40 & $9.6 \mathrm{E}-06$ & 2.01 & 9.0 & 3.0049 & $6.01 \mathrm{E}-02$ & (60) & $6.25 \mathrm{E}-04$ & 68 & $1.86 \mathrm{E}-04$ & 4,929 & $4.78 \mathrm{E}-03$ & 74,452 & $3.48 \mathrm{E}-04$ & $1.66 \mathrm{E}-09$ \\
\hline BKVX-5.3 & $6.89 \mathrm{E}+04$ & 40 & $9.5 \mathrm{E}-06$ & 3.25 & 9.0 & 3.0048 & $6.01 \mathrm{E}-02$ & (68) & $7.00 \mathrm{E}-04$ & 68 & $1.83 \mathrm{E}-04$ & 4,155 & $3.91 \mathrm{E}-03$ & 68,398 & - & $1.28 \mathrm{E}-09$ \\
\hline BKVX-5.4 & $6.89 \mathrm{E}+04$ & 40 & $9.5 \mathrm{E}-06$ & 4.37 & 9.0 & 3.0048 & $6.01 \mathrm{E}-02$ & (50) & $5.18 \mathrm{E}-04$ & 72 & $2.02 \mathrm{E}-04$ & 4,147 & $3.90 \mathrm{E}-03$ & 74,394 & $3.09 \mathrm{E}-04$ & $1.35 \mathrm{E}-09$ \\
\hline BKVX-5.5 & $6.89 \mathrm{E}+04$ & 40 & $9.7 \mathrm{E}-06$ & 5.19 & 9.0 & 3.0047 & $6.01 \mathrm{E}-02$ & (36) & $3.85 \mathrm{E}-04$ & 69 & $1.92 \mathrm{E}-04$ & 3,587 & $3.38 \mathrm{E}-03$ & 74,384 & $3.10 \mathrm{E}-04$ & $1.19 \mathrm{E}-09$ \\
\hline BKVX-5.11 & $6.89 \mathrm{E}+04$ & 40 & $9.6 \mathrm{E}-06$ & 19.08 & 9.0 & 3.0046 & $6.01 \mathrm{E}-02$ & (68) & $7.10 \mathrm{E}-04$ & 45 & 8.49E-05 & 1282 & $8.45 \mathrm{E}-04$ & 74053 & $1.04 \mathrm{E}-04$ & $5.40 \mathrm{E}-11$ \\
\hline BKVX-5.12 & $6.89 \mathrm{E}+04$ & 40 & $9.4 \mathrm{E}-06$ & 21.05 & 9.0 & 3.0045 & $6.01 \mathrm{E}-02$ & (69) & $7.10 \mathrm{E}-04$ & 42 & 7.34E-05 & 1175 & $7.20 \mathrm{E}-04$ & 74081 & $1.20 \mathrm{E}-04$ & $4.00 \mathrm{E}-12$ \\
\hline BKVX-5.13 & $6.89 \mathrm{E}+04$ & 40 & $9.6 \mathrm{E}-06$ & 26.00 & 9.0 & 3.0042 & $6.01 \mathrm{E}-02$ & (70) & 7.37E-04 & 42 & $7.29 \mathrm{E}-05$ & 1090 & $6.41 \mathrm{E}-04$ & 74197 & $1.93 \mathrm{E}-04$ & 0.00 \\
\hline $\begin{array}{c}\text { BKVX-5.14 } \\
\text { Exp. \#55 }\end{array}$ & $6.89 \mathrm{E}+04$ & 40 & $9.7 \mathrm{E}-06$ & 29.99 & 9.0 & 3.0039 & $6.01 \mathrm{E}-02$ & (72) & $7.72 \mathrm{E}-04$ & 37 & $5.46 \mathrm{E}-05$ & 945 & $4.90 \mathrm{E}-04$ & 74297 & $2.58 \mathrm{E}-04$ & 0.00 \\
\hline BKVX-6A & $7.64 \mathrm{E}+04$ & 40 & - & - & 9.0 & - & - & (0) & - & $<25$ & - & $<500$ & - & 85,206 & - & - \\
\hline BKVX-6.1 & $7.64 \mathrm{E}+04$ & 40 & 9.9E-06 & 1.16 & 9.0 & 3.0050 & $6.01 \mathrm{E}-02$ & (59) & $6.38 \mathrm{E}-04$ & 43 & $8.21 \mathrm{E}-05$ & 4,480 & $4.46 \mathrm{E}-03$ & 83,532 & - & $1.53 \mathrm{E}-09$ \\
\hline BKVX-6.2 & $7.64 \mathrm{E}+04$ & 40 & $9.6 \mathrm{E}-06$ & 2.01 & 9.0 & 3.0049 & $6.01 \mathrm{E}-02$ & (58) & $6.03 \mathrm{E}-04$ & 66 & $1.77 \mathrm{E}-04$ & 5,055 & $4.93 \mathrm{E}-03$ & 85,078 & - & $1.73 \mathrm{E}-09$ \\
\hline
\end{tabular}


Table B1. SPFT Temperature Sweep, Experimental Conditions, and Dissolution Rates. Data in parenthesis are near quantification limit.

\begin{tabular}{|c|c|c|c|c|c|c|c|c|c|c|c|c|c|c|c|c|}
\hline & Influent $\mathrm{Si}$ & & Flow Rate & Time & $\mathrm{pH}$ & Mass & Sur. Area & B & B Rate & $\mathrm{Al}$ & Al Rate & $\mathrm{Na}$ & Na Rate & $\mathrm{Si}$ & Si Rate & IEX Rate \\
\hline$\underline{\text { Sample ID }}$ & $\underline{\left(\mu g L^{-1}\right)}$ & $\frac{\mathrm{T}}{\left({ }^{\circ} \mathrm{C}\right)}$ & $\left(\mathrm{m}^{3} / \mathrm{day}\right)$ & $\underline{\text { (days) }}$ & $\underline{\left(23^{\circ} \mathrm{C}\right)}$ & $\underline{(\mathrm{g})}$ & $\left(\mathrm{m}^{2}\right)$ & $\left.\underline{(\mu \mathrm{g} \mathrm{L}}{ }^{-1}\right)$ & $\underline{\left(\mathrm{g} \mathrm{m}^{-2} \mathrm{~d}^{-1}\right)}$ & $\underline{\left(\mu g \mathrm{~L}^{-1}\right)}$ & $\underline{\left(\mathrm{g} \mathrm{m}^{-2} \mathrm{~d}^{-1}\right)}$ & $\underline{\left(\mu g L^{-1}\right)}$ & $\underline{\left(\mathrm{g} \mathrm{m}^{-2} \mathrm{~d}^{-1}\right)}$ & $\underline{\left(\mu g L^{-1}\right)}$ & $\underline{\left(\mathrm{g} \mathrm{m}^{-2} \mathrm{~d}^{-1}\right)}$ & $\left.\underline{(\mathrm{mol} \mathrm{m}} \mathrm{s}^{-2} \mathrm{~s}^{-1}\right)$ \\
\hline BKVX-6.5 & $7.64 \mathrm{E}+04$ & 40 & $9.4 \mathrm{E}-06$ & 5.19 & 9.0 & 3.0048 & $6.01 \mathrm{E}-02$ & (30) & $3.08 \mathrm{E}-04$ & 67 & $1.79 \mathrm{E}-04$ & 3,419 & $3.10 \mathrm{E}-03$ & 85,916 & $4.27 \mathrm{E}-04$ & $1.12 \mathrm{E}-09$ \\
\hline BKVX-6.11 & $7.64 \mathrm{E}+04$ & 40 & $9.4 \mathrm{E}-06$ & 19.08 & 9.0 & 3.0047 & $6.01 \mathrm{E}-02$ & (1) & $1.16 \mathrm{E}-05$ & 33 & $3.26 \mathrm{E}-05$ & 1218 & 7.64E-04 & 88678 & $2.09 \mathrm{E}-03$ & $3.01 \mathrm{E}-10$ \\
\hline BKVX-6.12 & $7.64 \mathrm{E}+04$ & 40 & $9.2 \mathrm{E}-06$ & 21.05 & 9.0 & 3.0046 & $6.01 \mathrm{E}-02$ & $<100$ & $1.00 \mathrm{E}-03$ & 31 & $2.42 \mathrm{E}-05$ & 1225 & $7.53 \mathrm{E}-04$ & 89323 & $2.42 \mathrm{E}-03$ & 0.00 \\
\hline BKVX-6.13 & $7.64 \mathrm{E}+04$ & 40 & $9.4 \mathrm{E}-06$ & 26.00 & 9.0 & 3.0043 & $6.01 \mathrm{E}-02$ & $<100$ & $1.03 \mathrm{E}-03$ & 28 & $1.07 \mathrm{E}-05$ & 1076 & $6.14 \mathrm{E}-04$ & 88901 & $2.23 \mathrm{E}-03$ & 0.00 \\
\hline $\begin{array}{c}\text { BKVX-6.14 } \\
\text { Exp.\#56 }\end{array}$ & $7.64 \mathrm{E}+04$ & 40 & $9.5 \mathrm{E}-06$ & 29.99 & 9.0 & 3.0039 & $6.01 \mathrm{E}-02$ & $<100$ & $1.04 \mathrm{E}-03$ & 25 & $4.70 \mathrm{E}-07$ & 925 & $4.57 \mathrm{E}-04$ & 88456 & $1.98 \mathrm{E}-03$ & 0.00 \\
\hline BKVX-13A & $8.67 \mathrm{E}+02$ & 70 & - & - & 9.0 & - & - & (15) & - & $<50$ & - & $<500$ & - & $<1000$ & - & - \\
\hline BKVX-13B & $8.67 \mathrm{E}+02$ & 70 & - & - & 9.0 & - & - & (6) & - & $<50$ & - & $<500$ & - & $<1000$ & - & - \\
\hline BKVX-13C & $8.67 \mathrm{E}+02$ & 70 & - & - & 9.0 & - & - & (2) & - & $<50$ & - & $<500$ & - & $<1000$ & - & - \\
\hline BKVX-13.1 & $8.67 \mathrm{E}+02$ & 70 & $4.1 \mathrm{E}-05$ & 1.00 & 9.0 & 1.0060 & $2.01 \mathrm{E}-02$ & $(0)$ & - & (7) & - & (5) & - & (137) & - & - \\
\hline BKVX-13.2 & $8.67 \mathrm{E}+02$ & 70 & $3.9 \mathrm{E}-05$ & 1.95 & 9.0 & 1.0055 & $2.01 \mathrm{E}-02$ & 188 & $2.31 \mathrm{E}-02$ & 646 & $3.15 \mathrm{E}-02$ & 4,503 & $5.30 \mathrm{E}-02$ & 4,867 & $2.90 \mathrm{E}-02$ & $1.19 \mathrm{E}-08$ \\
\hline BKVX-13.3 & $8.67 \mathrm{E}+02$ & 70 & 3.7E-05 & 3.18 & 9.0 & 1.0045 & $2.01 \mathrm{E}-02$ & 273 & $3.25 \mathrm{E}-02$ & 945 & $4.52 \mathrm{E}-02$ & 4,404 & $4.93 \mathrm{E}-02$ & 6,915 & $4.23 \mathrm{E}-02$ & $6.73 \mathrm{E}-09$ \\
\hline BKVX-13.4 & $8.67 \mathrm{E}+02$ & 70 & $4.0 \mathrm{E}-05$ & 3.92 & 9.0 & 1.0035 & $2.01 \mathrm{E}-02$ & 288 & $3.68 \mathrm{E}-02$ & 1,015 & $5.23 \mathrm{E}-02$ & 4,071 & $4.85 \mathrm{E}-02$ & 7,493 & 4.99E-02 & 4.67E-09 \\
\hline BKVX-13.5 & $8.67 \mathrm{E}+02$ & 70 & $3.7 \mathrm{E}-05$ & 5.10 & 9.0 & 1.0024 & $2.01 \mathrm{E}-02$ & 286 & $3.40 \mathrm{E}-02$ & 986 & $4.72 \mathrm{E}-02$ & 3,668 & $4.00 \mathrm{E}-02$ & 7,217 & $4.45 \mathrm{E}-02$ & $2.40 \mathrm{E}-09$ \\
\hline BKVX-13.6 & $8.67 \mathrm{E}+02$ & 70 & $4.0 \mathrm{E}-05$ & 6.01 & 9.0 & 1.0013 & $2.00 \mathrm{E}-02$ & 274 & $3.49 \mathrm{E}-02$ & 979 & $5.02 \mathrm{E}-02$ & 3,362 & $3.88 \mathrm{E}-02$ & 7,078 & $4.66 \mathrm{E}-02$ & $1.55 \mathrm{E}-09$ \\
\hline BKVX-13.9 & $8.67 \mathrm{E}+02$ & 70 & $3.6 \mathrm{E}-05$ & 8.77 & 9.0 & 0.9993 & $2.00 \mathrm{E}-02$ & 324 & $3.78 \mathrm{E}-02$ & 1,079 & $5.07 \mathrm{E}-02$ & 3,382 & $3.56 \mathrm{E}-02$ & 8,735 & $5.40 \mathrm{E}-02$ & 0.00 \\
\hline $\begin{array}{c}\text { BKVX13.11 } \\
\text { Exp. \#57 }\end{array}$ & $8.67 \mathrm{E}+02$ & 70 & $3.8 \mathrm{E}-05$ & 11.16 & 9.0 & 0.9979 & $2.00 \mathrm{E}-02$ & 332 & 4.07E-02 & 1,096 & $5.42 \mathrm{E}-02$ & 3,484 & $3.87 \mathrm{E}-02$ & 8,868 & $5.78 \mathrm{E}-02$ & 0.00 \\
\hline BKVX-14A & $2.93 \mathrm{E}+04$ & 70 & - & - & 9.0 & - & - & (13) & - & $<50$ & - & $<500$ & - & 33,215 & - & - \\
\hline BKVX-14B & $2.93 \mathrm{E}+04$ & 70 & - & - & 9.0 & - & - & (3) & - & $<50$ & - & $<500$ & - & 33,139 & - & - \\
\hline BKVX-14C & $2.93 \mathrm{E}+04$ & 70 & - & - & 9.0 & - & - & ND & - & $<50$ & - & $<500$ & - & 33,258 & - & - \\
\hline BKVX-14.1 & $2.93 \mathrm{E}+04$ & 70 & $2.2 \mathrm{E}-05$ & 1.00 & 9.0 & 1.0089 & $2.02 \mathrm{E}-02$ & $<100$ & $6.49 \mathrm{E}-03$ & (9) & - & (52) & - & 32,921 & - & - \\
\hline BKVX-14.2 & $2.93 \mathrm{E}+04$ & 70 & $2.4 \mathrm{E}-05$ & 1.95 & 9.0 & 1.0087 & $2.02 \mathrm{E}-02$ & (80) & $5.57 \mathrm{E}-03$ & 242 & $6.09 \mathrm{E}-03$ & 3,574 & $2.44 \mathrm{E}-02$ & 34,950 & $7.85 \mathrm{E}-03$ & 7.53E-09 \\
\hline BKVX-14.5 & $2.93 \mathrm{E}+04$ & 70 & $1.0 \mathrm{E}-06$ & 3.18 & 9.0 & 1.0086 & $2.02 \mathrm{E}-02$ & 128 & $3.98 \mathrm{E}-04$ & 436 & $5.29 \mathrm{E}-04$ & 3,739 & $1.11 \mathrm{E}-03$ & 36,261 & $5.93 \mathrm{E}-04$ & $2.85 \mathrm{E}-10$ \\
\hline BKVX-14.6 & $2.93 E+04$ & 70 & $1.2 \mathrm{E}-05$ & 3.92 & 9.0 & 1.0085 & $2.02 \mathrm{E}-02$ & 123 & 4.49E-03 & 421 & $5.94 \mathrm{E}-03$ & 3,143 & $1.06 \mathrm{E}-02$ & 35,979 & $6.29 \mathrm{E}-03$ & 2.44E-09 \\
\hline BKVX-14.7 & $2.93 \mathrm{E}+04$ & 70 & $3.3 \mathrm{E}-05$ & 5.10 & 9.0 & 1.0082 & $2.02 \mathrm{E}-02$ & 120 & $1.20 \mathrm{E}-02$ & 409 & $1.58 \mathrm{E}-02$ & 2,512 & $2.22 \mathrm{E}-02$ & 35,776 & $1.60 \mathrm{E}-02$ & 4.05E-09 \\
\hline BKVX-14.9 & $2.93 \mathrm{E}+04$ & 70 & $4.1 \mathrm{E}-05$ & 6.01 & 9.0 & 1.0078 & $2.02 \mathrm{E}-02$ & 110 & $1.36 \mathrm{E}-02$ & 386 & $1.85 \mathrm{E}-02$ & 2,263 & $2.43 \mathrm{E}-02$ & 39,844 & $5.18 \mathrm{E}-02$ & 4.25E-09 \\
\hline $\begin{array}{c}\text { BKVX14.11 } \\
\text { Exp. \#58 }\end{array}$ & $2.93 \mathrm{E}+04$ & 70 & $3.8 \mathrm{E}-05$ & 6.94 & 9.0 & 1.0073 & $2.01 \mathrm{E}-02$ & 139 & $1.63 \mathrm{E}-02$ & 484 & $2.22 \mathrm{E}-02$ & 2,331 & $2.35 \mathrm{E}-02$ & 39,381 & $4.48 \mathrm{E}-02$ & $2.86 \mathrm{E}-09$ \\
\hline BKVX-15A & $5.83 \mathrm{E}+04$ & 70 & - & - & 9.0 & - & - & (8) & - & $<50$ & - & $<500$ & - & 65,464 & - & - \\
\hline BKVX-15B & $5.83 \mathrm{E}+04$ & 70 & - & - & 9.0 & - & - & (0) & - & $<50$ & - & $<500$ & - & 65,163 & - & - \\
\hline BKVX-15C & $5.83 \mathrm{E}+04$ & 70 & - & - & 9.0 & - & - & (0) & - & $<50$ & - & $<500$ & - & 65,292 & - & - \\
\hline
\end{tabular}


Table B1. SPFT Temperature Sweep, Experimental Conditions, and Dissolution Rates. Data in parenthesis are near quantification limit.

\begin{tabular}{|c|c|c|c|c|c|c|c|c|c|c|c|c|c|c|c|c|}
\hline & Influent $\mathrm{Si}$ & & Flow Rate & Time & $\mathrm{pH}$ & Mass & Sur. Area & B & B Rate & $\mathrm{Al}$ & Al Rate & $\mathrm{Na}$ & Na Rate & $\mathrm{Si}$ & Si Rate & IEX Rate \\
\hline$\underline{\text { Sample ID }}$ & $\underline{\left(\mu \mathrm{L} \mathrm{L}^{-1}\right)}$ & $\frac{\mathrm{T}}{\left({ }^{\circ} \mathrm{C}\right)}$ & $\left(\mathrm{m}^{3} / \mathrm{day}\right)$ & $\underline{\text { (days) }}$ & $\underline{\left(23^{\circ} \mathrm{C}\right)}$ & $\underline{(\mathrm{g})}$ & $\left(\mathrm{m}^{2}\right)$ & $\underline{\left(\mu g \mathrm{~L}^{-1}\right)}$ & $\underline{\left(\mathrm{g} \mathrm{m}^{-2} \mathrm{~d}^{-1}\right)}$ & $\underline{\left(\mu g \mathrm{~L}^{-1}\right)}$ & $\underline{\left(\mathrm{g} \mathrm{m}^{-2} \mathrm{~d}^{-1}\right)}$ & $\underline{\left(\mu g \mathrm{~L}^{-1}\right)}$ & $\left(\mathrm{g} \mathrm{m}^{-2} \mathrm{~d}^{-1}\right)$ & $\underline{\left(\mu \mathrm{g} \mathrm{L}^{-1}\right)}$ & $\left(\mathrm{g} \mathrm{m}^{-2} \mathrm{~d}^{-1}\right)$ & $\underline{\left(\mathrm{mol} \mathrm{m} \mathrm{m}^{-2} \mathrm{~s}^{-1}\right)}$ \\
\hline BKVX-15.3 & $5.83 \mathrm{E}+04$ & 70 & $3.8 \mathrm{E}-05$ & 3.18 & 9.0 & 2.0017 & $4.00 \mathrm{E}-02$ & 144 & $8.47 \mathrm{E}-03$ & 412 & $9.31 \mathrm{E}-03$ & 7,040 & $4.21 \mathrm{E}-02$ & 68,455 & $1.15 \mathrm{E}-02$ & $1.34 \mathrm{E}-08$ \\
\hline BKVX-15.5 & $5.83 \mathrm{E}+04$ & 70 & $3.8 \mathrm{E}-05$ & 5.10 & 9.0 & 2.0006 & $4.00 \mathrm{E}-02$ & 150 & $8.72 \mathrm{E}-03$ & 429 & $9.62 \mathrm{E}-03$ & 5,012 & $2.87 \mathrm{E}-02$ & 68,406 & $1.12 \mathrm{E}-02$ & 7.99E-09 \\
\hline BKVX-15.6 & $5.83 \mathrm{E}+04$ & 70 & $3.8 \mathrm{E}-05$ & 6.01 & 9.0 & 2.0001 & $4.00 \mathrm{E}-02$ & 149 & $8.74 \mathrm{E}-03$ & 415 & $9.31 \mathrm{E}-03$ & 4,440 & $2.52 \mathrm{E}-02$ & 68,675 & $1.22 \mathrm{E}-02$ & $6.57 \mathrm{E}-09$ \\
\hline BKVX-15.7 & $5.83 \mathrm{E}+04$ & 70 & $4.0 \mathrm{E}-05$ & 6.94 & 9.0 & 1.9996 & $4.00 \mathrm{E}-02$ & 148 & $9.14 \mathrm{E}-03$ & 417 & $9.92 \mathrm{E}-03$ & 3,868 & $2.28 \mathrm{E}-02$ & 68,503 & $1.22 \mathrm{E}-02$ & $5.45 \mathrm{E}-09$ \\
\hline BKVX-15.9 & $5.83 \mathrm{E}+04$ & 70 & $3.7 \mathrm{E}-05$ & 8.77 & 9.0 & 1.9990 & $4.00 \mathrm{E}-02$ & 142 & $8.13 \mathrm{E}-03$ & 396 & $8.67 \mathrm{E}-03$ & 3,746 & $2.04 \mathrm{E}-02$ & 72,678 & $2.62 \mathrm{E}-02$ & $4.88 \mathrm{E}-09$ \\
\hline BKVX-16A & $8.84 \mathrm{E}+04$ & 70 & - & - & 9.0 & - & - & (8) & - & $<50$ & - & $<500$ & - & 80,491 & - & - \\
\hline BKVX-16B & $8.84 \mathrm{E}+04$ & 70 & - & - & 9.0 & - & - & $(0)$ & - & $<50$ & - & $<500$ & - & 101,545 & - & - \\
\hline BKVX-16C & $8.84 \mathrm{E}+04$ & 70 & - & - & 9.0 & - & - & $(0)$ & - & $<50$ & - & $<500$ & - & 95,404 & - & - \\
\hline BKVX-16.1 & $8.84 \mathrm{E}+04$ & 70 & $4.2 \mathrm{E}-05$ & 1.00 & 9.0 & 2.0067 & $4.01 \mathrm{E}-02$ & $<100$ & $6.29 \mathrm{E}-03$ & (9) & - & (23) & - & 97,754 & $2.11 \mathrm{E}-02$ & - \\
\hline BKVX-16.2 & $8.84 \mathrm{E}+04$ & 70 & $4.1 \mathrm{E}-05$ & 1.95 & 9.0 & 2.0064 & $4.01 \mathrm{E}-02$ & $(81)$ & $4.87 \mathrm{E}-03$ & 212 & $4.44 \mathrm{E}-03$ & 7,269 & $4.65 \mathrm{E}-02$ & 99,282 & $2.64 \mathrm{E}-02$ & $1.66 \mathrm{E}-08$ \\
\hline BKVX-16.3 & $8.84 \mathrm{E}+04$ & 70 & $3.9 \mathrm{E}-05$ & 3.18 & 9.0 & 2.0060 & $4.01 \mathrm{E}-02$ & (80) & $4.57 \mathrm{E}-03$ & 235 & $4.87 \mathrm{E}-03$ & 7,205 & $4.41 \mathrm{E}-02$ & 99,080 & $2.46 \mathrm{E}-02$ & $1.58 \mathrm{E}-08$ \\
\hline BKVX-16.4 & $8.84 \mathrm{E}+04$ & 70 & $3.5 \mathrm{E}-05$ & 3.92 & 9.0 & 2.0058 & $4.01 \mathrm{E}-02$ & (73) & $3.71 \mathrm{E}-03$ & 220 & $4.05 \mathrm{E}-03$ & 5,855 & $3.19 \mathrm{E}-02$ & 98,311 & $1.96 \mathrm{E}-02$ & $1.12 \mathrm{E}-08$ \\
\hline BKVX-16.6 & $8.84 \mathrm{E}+04$ & 70 & 3.9E-05 & 6.01 & 9.0 & 2.0052 & $4.01 \mathrm{E}-02$ & (71) & $3.98 \mathrm{E}-03$ & 211 & $4.24 \mathrm{E}-03$ & 4,499 & $2.63 \mathrm{E}-02$ & 97,946 & $2.03 \mathrm{E}-02$ & $8.90 \mathrm{E}-09$ \\
\hline BKVX-16.7 & $8.84 \mathrm{E}+04$ & 70 & $3.6 \mathrm{E}-05$ & 6.94 & 9.0 & 2.0050 & $4.01 \mathrm{E}-02$ & (66) & $3.44 \mathrm{E}-03$ & 206 & $3.85 \mathrm{E}-03$ & 4,121 & $2.23 \mathrm{E}-02$ & 97,898 & $1.89 \mathrm{E}-02$ & 7.55E-09 \\
\hline BKVX-16.9 & $8.84 \mathrm{E}+04$ & 70 & $3.7 \mathrm{E}-05$ & 8.77 & 9.0 & 2.0047 & $4.01 \mathrm{E}-02$ & $(80)$ & 4.30E-03 & 203 & $3.80 \mathrm{E}-03$ & 3,648 & $1.96 \mathrm{E}-02$ & 109,012 & $5.82 \mathrm{E}-02$ & $6.10 \mathrm{E}-09$ \\
\hline $\begin{array}{c}\text { BKVX16.11 } \\
\text { Exp. \#60 }\end{array}$ & $8.84 \mathrm{E}+04$ & 70 & $3.9 \mathrm{E}-05$ & 11.16 & 9.0 & 2.0044 & $4.01 \mathrm{E}-02$ & (70) & $3.98 \mathrm{E}-03$ & 182 & $3.50 \mathrm{E}-03$ & 3,329 & $1.88 \mathrm{E}-02$ & 107,501 & $5.65 \mathrm{E}-02$ & $5.92 \mathrm{E}-09$ \\
\hline BKVX-17A & $1.14 \mathrm{E}+05$ & 70 & - & - & 9.0 & - & - & (2) & - & $<50$ & - & $<500$ & - & 127,227 & - & - \\
\hline BKVX-17B & $1.14 \mathrm{E}+05$ & 70 & - & - & 9.0 & - & - & $(0)$ & - & $<50$ & - & $<500$ & - & 125,778 & - & - \\
\hline BKVX-17C & $1.14 \mathrm{E}+05$ & 70 & - & - & 9.0 & - & - & (0) & - & $<50$ & - & $<500$ & - & 125,062 & - & - \\
\hline BKVX-17.1 & $1.14 \mathrm{E}+05$ & 70 & $4.5 \mathrm{E}-05$ & 1.00 & 9.0 & 3.0057 & $6.01 \mathrm{E}-02$ & $<100$ & $4.86 \mathrm{E}-03$ & (9) & - & (27) & - & 135,017 & $2.57 \mathrm{E}-02$ & - \\
\hline BKVX-17.2 & $1.14 \mathrm{E}+05$ & 70 & 4.2E-05 & 1.95 & 9.0 & 3.0053 & $6.01 \mathrm{E}-02$ & (89) & $4.03 \mathrm{E}-03$ & 163 & $2.13 \mathrm{E}-03$ & 10,399 & $4.66 \mathrm{E}-02$ & 139,531 & $3.60 \mathrm{E}-02$ & $1.70 \mathrm{E}-08$ \\
\hline BKVX-17.3 & $1.14 \mathrm{E}+05$ & 70 & $3.8 \mathrm{E}-05$ & 3.18 & 9.0 & 3.0050 & $6.01 \mathrm{E}-02$ & (68) & $2.77 \mathrm{E}-03$ & 167 & $1.98 \mathrm{E}-03$ & 10,012 & 4.04E-02 & 128,725 & $6.50 \mathrm{E}-03$ & $1.50 \mathrm{E}-08$ \\
\hline BKVX-17.4 & $1.14 \mathrm{E}+05$ & 70 & $4.0 \mathrm{E}-05$ & 3.92 & 9.0 & 3.0048 & $6.01 \mathrm{E}-02$ & (55) & 2.39E-03 & 178 & $2.31 \mathrm{E}-03$ & 7,900 & $3.34 \mathrm{E}-02$ & 121,948 & 0.00 & $1.24 \mathrm{E}-08$ \\
\hline BKVX-17.5 & $1.14 \mathrm{E}+05$ & 70 & $3.9 \mathrm{E}-05$ & 5.10 & 9.0 & 3.0046 & $6.01 \mathrm{E}-02$ & (48) & $2.02 \mathrm{E}-03$ & 172 & $2.14 \mathrm{E}-03$ & 6,362 & $2.57 \mathrm{E}-02$ & 119,444 & 0.00 & $9.46 \mathrm{E}-09$ \\
\hline BKVX-17.6 & $1.14 \mathrm{E}+05$ & 70 & $3.6 \mathrm{E}-05$ & 6.01 & 9.0 & 3.0044 & $6.01 \mathrm{E}-02$ & (45) & $1.77 \mathrm{E}-03$ & 163 & $1.85 \mathrm{E}-03$ & 5,722 & $2.13 \mathrm{E}-02$ & 121,032 & 0.00 & 7.79E-09 \\
\hline BKVX-17.7 & $1.14 \mathrm{E}+05$ & 70 & $4.0 \mathrm{E}-05$ & 6.94 & 9.0 & 3.0043 & $6.01 \mathrm{E}-02$ & (43) & $1.85 \mathrm{E}-03$ & 157 & $1.94 \mathrm{E}-03$ & 5,201 & $2.14 \mathrm{E}-02$ & 120,293 & 0.00 & $7.80 \mathrm{E}-09$ \\
\hline BKVX-17.9 & $1.14 \mathrm{E}+05$ & 70 & $4.0 \mathrm{E}-05$ & 8.77 & 9.0 & 3.0042 & $6.01 \mathrm{E}-02$ & (26) & $1.14 \mathrm{E}-03$ & 129 & $1.44 \mathrm{E}-03$ & 4,591 & $1.87 \mathrm{E}-02$ & 130,662 & $1.20 \mathrm{E}-02$ & 7.01E-09 \\
\hline $\begin{array}{c}\text { BKVX17.11 } \\
\text { Exp. \#61 }\end{array}$ & $1.14 \mathrm{E}+05$ & 70 & 3.7E-05 & 11.16 & 9.0 & 3.0040 & $6.01 \mathrm{E}-02$ & (37) & $1.50 \mathrm{E}-03$ & 101 & $8.56 \mathrm{E}-04$ & 3,998 & $1.48 \mathrm{E}-02$ & 134,927 & $2.14 \mathrm{E}-02$ & 5.32E-09 \\
\hline
\end{tabular}


Table B1. SPFT Temperature Sweep, Experimental Conditions, and Dissolution Rates. Data in parenthesis are near quantification limit.

\begin{tabular}{|c|c|c|c|c|c|c|c|c|c|c|c|c|c|c|c|c|}
\hline & Influent $\mathrm{Si}$ & & Flow Rate & Time & $\mathrm{pH}$ & Mass & Sur. Area & B & B Rate & $\mathrm{Al}$ & Al Rate & $\mathrm{Na}$ & Na Rate & $\mathrm{Si}$ & Si Rate & IEX Rate \\
\hline$\underline{\text { Sample ID }}$ & $\underline{\left(\mu g L^{-1}\right)}$ & $\frac{\mathrm{T}}{\left({ }^{\circ} \mathrm{C}\right)}$ & $\underline{\left(\mathrm{m}^{3} / \mathrm{day}\right)}$ & $\underline{\text { (days) }}$ & $\underline{\left(23^{\circ} \mathrm{C}\right)}$ & $\underline{(\mathrm{g})}$ & $\underline{\left(\mathrm{m}^{2}\right)}$ & $\underline{\left(\mu \mathrm{g} \mathrm{L}^{-1}\right)}$ & $\underline{\left(\mathrm{g} \mathrm{m}^{-2} \mathrm{~d}^{-1}\right)}$ & $\left.\underline{(\mu \mathrm{g} \mathrm{L}} \mathrm{L}^{-1}\right)$ & $\underline{\left(\mathrm{g} \mathrm{m}^{-2} \mathrm{~d}^{-1}\right)}$ & $\underline{\left(\mu \mathrm{g} \mathrm{L}^{-1}\right)}$ & $\underline{\left(\mathrm{g} \mathrm{m}^{-2} \mathrm{~d}^{-1}\right)}$ & $\left.\underline{(\mu \mathrm{g} \mathrm{L}} \mathrm{L}^{-1}\right)$ & $\underline{\left(\mathrm{g} \mathrm{m}^{-2} \mathrm{~d}^{-1}\right)}$ & $\left.\underline{(\mathrm{mol} \mathrm{m}} \mathrm{s}^{-2} \mathrm{~s}^{-1}\right)$ \\
\hline BKVX-18B & $1.37 \mathrm{E}+05$ & 70 & - & - & 9.0 & - & - & $(0)$ & - & $<50$ & - & $<500$ & - & 154,032 & - & - \\
\hline BKVX-18.1 & $1.37 \mathrm{E}+05$ & 70 & $3.9 \mathrm{E}-05$ & 1.00 & 9.0 & 3.008 & $6.01 \mathrm{E}-02$ & $<100$ & $4.26 \mathrm{E}-03$ & (8) & - & (30) & - & 164,413 & $2.85 \mathrm{E}-02$ & - \\
\hline BKVX-18.2 & $1.37 \mathrm{E}+05$ & 70 & $3.9 \mathrm{E}-05$ & 1.95 & 9.0 & 3.007 & $6.01 \mathrm{E}-02$ & (74) & $3.17 \mathrm{E}-03$ & 119 & $1.21 \mathrm{E}-03$ & 9,798 & 4.09E-02 & 167,917 & $3.72 \mathrm{E}-02$ & $1.51 \mathrm{E}-08$ \\
\hline BKVX-18.3 & $1.37 \mathrm{E}+05$ & 70 & $3.8 \mathrm{E}-05$ & 3.18 & 9.0 & 3.007 & $6.01 \mathrm{E}-02$ & $(50)$ & $2.06 \mathrm{E}-03$ & 121 & $1.21 \mathrm{E}-03$ & 10,232 & 4.14E-02 & 160,764 & $1.87 \mathrm{E}-02$ & $1.57 \mathrm{E}-08$ \\
\hline BKVX-18.4 & $1.37 \mathrm{E}+05$ & 70 & $4.1 \mathrm{E}-05$ & 3.92 & 9.0 & 3.007 & $6.01 \mathrm{E}-02$ & (31) & $1.40 \mathrm{E}-03$ & 117 & $1.24 \mathrm{E}-03$ & 7,935 & $3.47 \mathrm{E}-02$ & 154,822 & $4.84 \mathrm{E}-03$ & $1.33 \mathrm{E}-08$ \\
\hline BKVX-18.6 & $1.37 \mathrm{E}+05$ & 70 & $4.1 \mathrm{E}-05$ & 6.01 & 9.0 & 3.007 & $6.01 \mathrm{E}-02$ & (20) & $9.10 \mathrm{E}-04$ & 102 & $9.68 \mathrm{E}-04$ & 5,741 & $2.44 \mathrm{E}-02$ & 146,310 & 0.00 & $9.37 \mathrm{E}-09$ \\
\hline BKVX-18.7 & $1.37 \mathrm{E}+05$ & 70 & $3.7 \mathrm{E}-05$ & 6.94 & 9.0 & 3.007 & $6.01 \mathrm{E}-02$ & (25) & $1.01 \mathrm{E}-03$ & 120 & $1.18 \mathrm{E}-03$ & 5,110 & $1.95 \mathrm{E}-02$ & 139,516 & 0.00 & 7.38E-09 \\
\hline BKVX-18.9 & $1.37 \mathrm{E}+05$ & 70 & $3.6 \mathrm{E}-05$ & 8.77 & 9.0 & 3.007 & $6.01 \mathrm{E}-02$ & (19) & $7.40 \mathrm{E}-04$ & 108 & $9.43 \mathrm{E}-04$ & 4,324 & $1.57 \mathrm{E}-02$ & 151,374 & 0.00 & $5.97 \mathrm{E}-09$ \\
\hline $\begin{array}{c}\text { BKVX18.11 } \\
\text { Exp. \#62 }\end{array}$ & $1.37 \mathrm{E}+05$ & 70 & $4.6 \mathrm{E}-05$ & 11.16 & 9.0 & 3.007 & $6.01 \mathrm{E}-02$ & (25) & $1.28 \mathrm{E}-03$ & (96) & $9.59 \mathrm{E}-04$ & 4,049 & $1.86 \mathrm{E}-02$ & 153,511 & $1.54 \mathrm{E}-03$ & $6.92 \mathrm{E}-09$ \\
\hline BKVX-19A & $8.79 \mathrm{E}+02$ & 90 & - & - & 9.0 & - & - & (15) & - & $<50$ & - & $<500$ & - & $<1000$ & - & - \\
\hline BKVX-19B & $8.79 \mathrm{E}+02$ & 90 & - & - & 9.0 & - & - & (7) & - & $<50$ & - & $<500$ & - & $<1000$ & - & - \\
\hline BKVX-19C & $8.79 \mathrm{E}+02$ & 90 & - & - & 9.0 & - & - & (4) & - & $<50$ & - & $<500$ & - & $<1000$ & - & - \\
\hline BKVX-19.3 & $8.79 \mathrm{E}+02$ & 90 & $3.6 \mathrm{E}-05$ & 4.11 & 9.0 & 1.0014 & $2.00 \mathrm{E}-02$ & 434 & $4.95 \mathrm{E}-02$ & 1,504 & $6.98 \mathrm{E}-02$ & 4,783 & $5.15 \mathrm{E}-02$ & 10,828 & $6.69 \mathrm{E}-02$ & $8.06 \mathrm{E}-10$ \\
\hline BKVX-19.4 & $8.79 \mathrm{E}+02$ & 90 & $4.6 \mathrm{E}-05$ & 5.06 & 9.0 & 0.9989 & $2.00 \mathrm{E}-02$ & 543 & $8.00 \mathrm{E}-02$ & 1,793 & $1.08 \mathrm{E}-01$ & 6,046 & 8.59E-02 & 13,283 & $1.08 \mathrm{E}-01$ & 2.33E-09 \\
\hline BKVX-19.6 & $8.79 \mathrm{E}+02$ & 90 & $5.6 \mathrm{E}-05$ & 7.14 & 9.0 & 0.9948 & $1.99 \mathrm{E}-02$ & 820 & $1.49 \mathrm{E}-01$ & 2,352 & $1.74 \mathrm{E}-01$ & 7,483 & $1.33 \mathrm{E}-01$ & 10,075 & $9.75 \mathrm{E}-02$ & 0.00 \\
\hline BKVX-19.8 & $8.79 \mathrm{E}+02$ & 90 & $5.0 \mathrm{E}-05$ & 9.17 & 9.0 & 0.9916 & $1.99 \mathrm{E}-02$ & 474 & 7.64E-02 & 1,563 & $1.03 \mathrm{E}-01$ & 4,700 & 7.13E-02 & 11,674 & $1.03 \mathrm{E}-01$ & 0.00 \\
\hline BKVX19.10 & $8.79 \mathrm{E}+02$ & 90 & $5.5 \mathrm{E}-05$ & 11.32 & 9.0 & 0.9888 & $1.98 \mathrm{E}-02$ & 456 & $8.20 \mathrm{E}-02$ & 1,506 & $1.10 \mathrm{E}-01$ & 4,354 & $7.30 \mathrm{E}-02$ & 11,433 & $1.12 \mathrm{E}-01$ & 0.00 \\
\hline BKVX19.12 & $8.79 \mathrm{E}+02$ & 90 & $3.8 \mathrm{E}-05$ & 13.12 & 9.0 & 0.9866 & $1.97 \mathrm{E}-02$ & 467 & $5.73 \mathrm{E}-02$ & 1,526 & $7.60 \mathrm{E}-02$ & 4,495 & $5.16 \mathrm{E}-02$ & 11,720 & $7.83 \mathrm{E}-02$ & 0.00 \\
\hline BKVX19.14 & $8.79 \mathrm{E}+02$ & 90 & $5.8 \mathrm{E}-05$ & 14.97 & 9.0 & 0.9844 & $1.97 \mathrm{E}-02$ & 469 & $8.95 \mathrm{E}-02$ & 1,272 & $9.80 \mathrm{E}-02$ & 4,485 & $8.01 \mathrm{E}-02$ & 17,593 & $1.89 \mathrm{E}-01$ & 0.00 \\
\hline BKVX19.16 & $8.79 \mathrm{E}+02$ & 90 & $5.7 \mathrm{E}-05$ & 17.29 & 9.0 & 0.9815 & $1.96 \mathrm{E}-02$ & 464 & $8.73 \mathrm{E}-02$ & 1,532 & $1.17 \mathrm{E}-01$ & 4,549 & 8.03E-02 & 11,445 & $1.17 \mathrm{E}-01$ & 0.00 \\
\hline $\begin{array}{c}\text { BKVX19.18 } \\
\text { Exp. \#63 }\end{array}$ & $8.79 \mathrm{E}+02$ & 90 & $5.0 \mathrm{E}-05$ & 18.92 & 9.0 & 0.9790 & $1.96 \mathrm{E}-02$ & 485 & 8.03E-02 & 1,596 & $1.07 \mathrm{E}-01$ & 4,729 & 7.37E-02 & 11,900 & $1.07 \mathrm{E}-01$ & 0.00 \\
\hline BKVX-20A & $3.74 \mathrm{E}+04$ & 90 & - & - & 9.0 & - & - & $(0)$ & - & $<50$ & - & $<500$ & - & 43,697 & - & - \\
\hline BKVX-20B & $3.74 \mathrm{E}+04$ & 90 & - & - & 9.0 & - & - & (0) & - & $<50$ & - & $<500$ & - & 42,649 & - & - \\
\hline BKVX-20C & $3.74 \mathrm{E}+04$ & 90 & - & - & 9.0 & - & - & (0) & - & $<50$ & - & $<500$ & - & 42,653 & - & - \\
\hline BKVX-20.2 & $3.74 \mathrm{E}+04$ & 90 & $5.6 \mathrm{E}-05$ & 2.18 & 9.0 & 1.0074 & $2.01 \mathrm{E}-02$ & 151 & $2.75 \mathrm{E}-02$ & 392 & $2.57 \mathrm{E}-02$ & 3,182 & $5.06 \mathrm{E}-02$ & 45,172 & $2.32 \mathrm{E}-02$ & $9.21 \mathrm{E}-09$ \\
\hline BKVX-20.3 & $3.74 \mathrm{E}+04$ & 90 & $6.1 \mathrm{E}-05$ & 4.11 & 9.0 & 1.0060 & $2.01 \mathrm{E}-02$ & 143 & $2.84 \mathrm{E}-02$ & 412 & $2.96 \mathrm{E}-02$ & 2,370 & $3.84 \mathrm{E}-02$ & 44,809 & $2.10 \mathrm{E}-02$ & $3.99 \mathrm{E}-09$ \\
\hline BKVX-20.4 & $3.74 \mathrm{E}+04$ & 90 & $5.6 \mathrm{E}-05$ & 5.06 & 9.0 & 1.0050 & $2.01 \mathrm{E}-02$ & 133 & $2.44 \mathrm{E}-02$ & 404 & $2.69 \mathrm{E}-02$ & 1,867 & $2.60 \mathrm{E}-02$ & 44,724 & $1.85 \mathrm{E}-02$ & $6.14 \mathrm{E}-10$ \\
\hline BKVX-20.6 & $3.74 \mathrm{E}+04$ & 90 & $5.5 \mathrm{E}-05$ & 7.14 & 9.0 & 1.0038 & $2.01 \mathrm{E}-02$ & 239 & $4.33 \mathrm{E}-02$ & 609 & $4.18 \mathrm{E}-02$ & 4,325 & $7.16 \mathrm{E}-02$ & 44,304 & $1.38 \mathrm{E}-02$ & $1.13 \mathrm{E}-08$ \\
\hline BKVX20.12 & $3.74 \mathrm{E}+04$ & 90 & $6.4 \mathrm{E}-05$ & 13.12 & 9.0 & 1.0012 & $2.00 \mathrm{E}-02$ & 118 & $2.48 \mathrm{E}-02$ & 393 & $2.98 \mathrm{E}-02$ & 1,427 & $2.02 \mathrm{E}-02$ & 49,982 & $8.60 \mathrm{E}-02$ & 0.00 \\
\hline
\end{tabular}


Table B1. SPFT Temperature Sweep, Experimental Conditions, and Dissolution Rates. Data in parenthesis are near quantification limit.

\begin{tabular}{|c|c|c|c|c|c|c|c|c|c|c|c|c|c|c|c|c|}
\hline & Influent $\mathrm{Si}$ & & Flow Rate & Time & $\mathrm{pH}$ & Mass & Sur. Area & B & B Rate & $\mathrm{Al}$ & Al Rate & $\mathrm{Na}$ & Na Rate & $\mathrm{Si}$ & Si Rate & IEX Rate \\
\hline$\underline{\text { Sample ID }}$ & $\underline{\left(\mu \mathrm{L} \mathrm{L}^{-1}\right)}$ & $\frac{\mathrm{T}}{\left({ }^{\circ} \mathrm{C}\right)}$ & $\underline{\left(\mathrm{m}^{3} / \mathrm{day}\right)}$ & $\underline{\text { (days) }}$ & $\underline{\left(23^{\circ} \mathrm{C}\right)}$ & $\underline{(\mathrm{g})}$ & $\left(\mathrm{m}^{2}\right)$ & $\underline{\left(\mu g \mathrm{~L}^{-1}\right)}$ & $\underline{\left(\mathrm{g} \mathrm{m}^{-2} \mathrm{~d}^{-1}\right)}$ & $\underline{\left(\mu g \mathrm{~L}^{-1}\right)}$ & $\underline{\left(\mathrm{g} \mathrm{m}^{-2} \mathrm{~d}^{-1}\right)}$ & $\underline{\left(\mu g \mathrm{~L}^{-1}\right)}$ & $\left(\mathrm{g} \mathrm{m}^{-2} \mathrm{~d}^{-1}\right)$ & $\underline{\left(\mu \mathrm{g} \mathrm{L}^{-1}\right)}$ & $\left(\mathrm{g} \mathrm{m}^{-2} \mathrm{~d}^{-1}\right)$ & $\underline{\left(\mathrm{mol} \mathrm{m} \mathrm{m}^{-2} \mathrm{~s}^{-1}\right)}$ \\
\hline BKVX20.14 & $3.74 \mathrm{E}+04$ & 90 & $6.1 \mathrm{E}-05$ & 14.97 & 9.0 & 1.0006 & $2.00 \mathrm{E}-02$ & 103 & $2.06 \mathrm{E}-02$ & 335 & $2.36 \mathrm{E}-02$ & 1,277 & $1.61 \mathrm{E}-02$ & 50,309 & 8.57E-02 & 0.00 \\
\hline BKVX20.16 & $3.74 \mathrm{E}+04$ & 90 & $6.0 \mathrm{E}-05$ & 17.29 & 9.0 & 0.9998 & $2.00 \mathrm{E}-02$ & 120 & $2.37 \mathrm{E}-02$ & 365 & $2.55 \mathrm{E}-02$ & 1,247 & $1.52 \mathrm{E}-02$ & 49,860 & $7.88 \mathrm{E}-02$ & 0.00 \\
\hline $\begin{array}{c}\text { BKVX20.18 } \\
\text { Exp. \#64 }\end{array}$ & $3.74 \mathrm{E}+04$ & 90 & $5.3 \mathrm{E}-05$ & 18.92 & 9.0 & 0.9991 & $2.00 \mathrm{E}-02$ & 128 & $2.21 \mathrm{E}-02$ & 435 & $2.75 \mathrm{E}-02$ & 1,316 & $1.46 \mathrm{E}-02$ & 45,276 & $2.30 \mathrm{E}-02$ & 0.00 \\
\hline BKVX-21A & $7.39 \mathrm{E}+04$ & 90 & - & - & 9.0 & - & - & $(0)$ & - & $<50$ & - & $<500$ & - & 83,653 & - & - \\
\hline BKVX-21B & $7.39 \mathrm{E}+04$ & 90 & - & - & 9.0 & - & - & (0) & - & $<50$ & - & $<500$ & - & 84,280 & - & - \\
\hline BKVX-21C & $7.39 \mathrm{E}+04$ & 90 & - & - & 9.0 & - & - & $(0)$ & - & $<50$ & - & $<500$ & - & 84,146 & - & - \\
\hline BKVX-21.2 & $7.39 \mathrm{E}+04$ & 90 & $5.7 \mathrm{E}-05$ & 2.18 & 9.0 & 2.0034 & $4.01 \mathrm{E}-02$ & 145 & $1.36 \mathrm{E}-02$ & 367 & $1.22 \mathrm{E}-02$ & 8,559 & $7.80 \mathrm{E}-02$ & 86,793 & $1.51 \mathrm{E}-02$ & $2.57 \mathrm{E}-08$ \\
\hline BKVX-21.3 & $7.39 \mathrm{E}+04$ & 90 & $5.8 \mathrm{E}-05$ & 4.11 & 9.0 & 2.0020 & $4.00 \mathrm{E}-02$ & 145 & $1.39 \mathrm{E}-02$ & 372 & $1.27 \mathrm{E}-02$ & 5,898 & $5.35 \mathrm{E}-02$ & 86,717 & $1.51 \mathrm{E}-02$ & $1.58 \mathrm{E}-08$ \\
\hline BKVX-21.4 & $7.39 \mathrm{E}+04$ & 90 & $5.7 \mathrm{E}-05$ & 5.06 & 9.0 & 2.0010 & $4.00 \mathrm{E}-02$ & 139 & $1.31 \mathrm{E}-02$ & 369 & $1.24 \mathrm{E}-02$ & 4,855 & $4.23 \mathrm{E}-02$ & 87,020 & $1.64 \mathrm{E}-02$ & $1.17 \mathrm{E}-08$ \\
\hline BKVX-21.6 & $7.39 \mathrm{E}+04$ & 90 & $5.9 \mathrm{E}-05$ & 7.14 & 9.0 & 1.9998 & $4.00 \mathrm{E}-02$ & 219 & $2.12 \mathrm{E}-02$ & 482 & $1.73 \mathrm{E}-02$ & 8,818 & $8.32 \mathrm{E}-02$ & 87,377 & $1.90 \mathrm{E}-02$ & $2.48 \mathrm{E}-08$ \\
\hline BKVX-21.8 & $7.39 \mathrm{E}+04$ & 90 & $5.7 \mathrm{E}-05$ & 9.17 & 9.0 & 1.9988 & $4.00 \mathrm{E}-02$ & 154 & $1.43 \mathrm{E}-02$ & 428 & $1.46 \mathrm{E}-02$ & 3,786 & $3.17 \mathrm{E}-02$ & 87,860 & $2.09 \mathrm{E}-02$ & $6.93 \mathrm{E}-09$ \\
\hline BKVX21.10 & $7.39 \mathrm{E}+04$ & 90 & $5.5 \mathrm{E}-05$ & 11.32 & 9.0 & 1.9978 & $4.00 \mathrm{E}-02$ & 149 & $1.36 \mathrm{E}-02$ & 430 & $1.43 \mathrm{E}-02$ & 3,529 & $2.85 \mathrm{E}-02$ & 87,847 & $2.04 \mathrm{E}-02$ & $5.97 \mathrm{E}-09$ \\
\hline BKVX21.12 & $7.39 \mathrm{E}+04$ & 90 & $5.5 \mathrm{E}-05$ & 13.12 & 9.0 & 1.9969 & $3.99 \mathrm{E}-02$ & 144 & $1.29 \mathrm{E}-02$ & 408 & $1.33 \mathrm{E}-02$ & 3,173 & $2.49 \mathrm{E}-02$ & 87,283 & $1.72 \mathrm{E}-02$ & 4.76E-09 \\
\hline BKVX21.14 & $7.39 \mathrm{E}+04$ & 90 & $6.1 \mathrm{E}-05$ & 14.97 & 9.0 & 1.9963 & $3.99 \mathrm{E}-02$ & 117 & $1.18 \mathrm{E}-02$ & 342 & $1.22 \mathrm{E}-02$ & 2,544 & $2.14 \mathrm{E}-02$ & 84,432 & $2.40 \mathrm{E}-03$ & $3.82 \mathrm{E}-09$ \\
\hline $\begin{array}{c}\text { BKVX21.18 } \\
\text { Exp. \#65 }\end{array}$ & $7.39 \mathrm{E}+04$ & 90 & $5.7 \mathrm{E}-05$ & 18.92 & 9.0 & 1.9947 & $3.99 \mathrm{E}-02$ & 156 & $1.48 \mathrm{E}-02$ & 456 & $1.58 \mathrm{E}-02$ & 2,688 & $2.14 \mathrm{E}-02$ & 85,523 & $8.27 \mathrm{E}-03$ & 2.64E-09 \\
\hline BKVX-22A & $1.06 \mathrm{E}+05$ & 90 & - & - & 9.0 & - & - & $(0)$ & - & $<50$ & - & $<500$ & - & 123,645 & - & - \\
\hline BKVX-22B & $1.06 \mathrm{E}+05$ & 90 & - & - & 9.0 & - & - & (0) & - & $<50$ & - & $<500$ & - & 123,966 & - & - \\
\hline BKVX-22C & $1.06 \mathrm{E}+05$ & 90 & - & - & 9.0 & - & - & (0) & - & $<50$ & - & $<500$ & - & 122,378 & - & - \\
\hline BKVX-22.2 & $1.06 \mathrm{E}+05$ & 90 & $5.3 \mathrm{E}-05$ & 2.18 & 9.0 & 2.0086 & $4.02 \mathrm{E}-02$ & 105 & $9.20 \mathrm{E}-03$ & 221 & $6.16 \mathrm{E}-03$ & 11,952 & $1.03 \mathrm{E}-01$ & 125,244 & $9.79 \mathrm{E}-03$ & $3.76 \mathrm{E}-08$ \\
\hline BKVX-22.3 & $1.06 \mathrm{E}+05$ & 90 & $5.6 \mathrm{E}-05$ & 4.11 & 9.0 & 2.0080 & $4.02 \mathrm{E}-02$ & (52) & $4.83 \mathrm{E}-03$ & 162 & $4.27 \mathrm{E}-03$ & 6,302 & $5.53 \mathrm{E}-02$ & 127,454 & $2.22 \mathrm{E}-02$ & $2.02 \mathrm{E}-08$ \\
\hline BKVX-22.4 & $1.06 \mathrm{E}+05$ & 90 & $6.1 \mathrm{E}-05$ & 5.06 & 9.0 & 2.0077 & $4.02 \mathrm{E}-02$ & (44) & $4.47 \mathrm{E}-03$ & 145 & $3.96 \mathrm{E}-03$ & 4,597 & $4.26 \mathrm{E}-02$ & 126,688 & $1.98 \mathrm{E}-02$ & $1.52 \mathrm{E}-08$ \\
\hline BKVX-22.6 & $1.06 \mathrm{E}+05$ & 90 & $5.9 \mathrm{E}-05$ & 7.14 & 9.0 & 2.0074 & $4.01 \mathrm{E}-02$ & (37) & $3.62 \mathrm{E}-03$ & 120 & $2.80 \mathrm{E}-03$ & 7,669 & $7.18 \mathrm{E}-02$ & 126,101 & $1.57 \mathrm{E}-02$ & $2.72 \mathrm{E}-08$ \\
\hline BKVX-22.8 & $1.06 \mathrm{E}+05$ & 90 & $5.3 \mathrm{E}-05$ & 9.17 & 9.0 & 2.0072 & 4.01E-02 & (49) & $4.22 \mathrm{E}-03$ & 167 & $4.20 \mathrm{E}-03$ & 3,599 & $2.79 \mathrm{E}-02$ & 124,157 & $4.21 \mathrm{E}-03$ & $9.44 \mathrm{E}-09$ \\
\hline BKVX22.10 & $1.06 \mathrm{E}+05$ & 90 & $5.6 \mathrm{E}-05$ & 11.32 & 9.0 & 2.0069 & $4.01 \mathrm{E}-02$ & (48) & 4.44E-03 & 168 & 4.47E-03 & 3,179 & $2.54 \mathrm{E}-02$ & 125,918 & $1.39 \mathrm{E}-02$ & 8.38E-09 \\
\hline BKVX22.12 & $1.06 \mathrm{E}+05$ & 90 & $6.3 \mathrm{E}-05$ & 13.12 & 9.0 & 2.0066 & $4.01 \mathrm{E}-02$ & (45) & $4.60 \mathrm{E}-03$ & 160 & 4.67E-03 & 3,105 & $2.76 \mathrm{E}-02$ & 126,911 & $2.15 \mathrm{E}-02$ & $9.17 \mathrm{E}-09$ \\
\hline BKVX22.14 & $1.06 \mathrm{E}+05$ & 90 & $5.5 \mathrm{E}-05$ & 14.97 & 9.0 & 2.0063 & $4.01 \mathrm{E}-02$ & (43) & $3.91 \mathrm{E}-03$ & 158 & $4.02 \mathrm{E}-03$ & 2,796 & $2.14 \mathrm{E}-02$ & 124,711 & $7.29 \mathrm{E}-03$ & $6.98 \mathrm{E}-09$ \\
\hline BKVX22.16 & $1.06 \mathrm{E}+05$ & 90 & $5.8 \mathrm{E}-05$ & 17.29 & 9.0 & 2.0058 & $4.01 \mathrm{E}-02$ & (89) & 8.39E-03 & 264 & $8.33 \mathrm{E}-03$ & 3,058 & $2.49 \mathrm{E}-02$ & 126,658 & $1.84 \mathrm{E}-02$ & $6.60 \mathrm{E}-09$ \\
\hline $\begin{array}{c}\text { BKVX22.18 } \\
\text { Exp. \#66 }\end{array}$ & $1.06 \mathrm{E}+05$ & 90 & $5.3 \mathrm{E}-05$ & 18.92 & 9.0 & 2.0054 & $4.01 \mathrm{E}-02$ & (89) & 7.72E-03 & 267 & $7.74 \mathrm{E}-03$ & 2,985 & $2.22 \mathrm{E}-02$ & 124,321 & $5.01 \mathrm{E}-03$ & $5.77 \mathrm{E}-09$ \\
\hline
\end{tabular}


Table B1. SPFT Temperature Sweep, Experimental Conditions, and Dissolution Rates. Data in parenthesis are near quantification limit.

\begin{tabular}{|c|c|c|c|c|c|c|c|c|c|c|c|c|c|c|c|c|}
\hline$\underline{\text { Sample ID }}$ & $\begin{array}{l}\text { Influent } \mathrm{Si} \\
\underline{\left(\mu \mathrm{g} \mathrm{L}^{-1}\right)}\end{array}$ & $\stackrel{\frac{\mathrm{T}}{\left({ }^{o} \mathrm{C}\right)}}{(}$ & $\begin{array}{l}\text { Flow Rate } \\
\underline{\left(\mathrm{m}^{3} / \mathrm{day}\right)}\end{array}$ & $\begin{array}{l}\text { Time } \\
\underline{\text { (days) }}\end{array}$ & $\begin{array}{c}\mathrm{pH} \\
\left(23^{\circ} \mathrm{C}\right) \\
\end{array}$ & $\begin{array}{l}\text { Mass } \\
\underline{(\mathrm{g})}\end{array}$ & $\begin{array}{l}\text { Sur. Area } \\
\qquad \underline{\left(\mathrm{m}^{2}\right)}\end{array}$ & $\begin{array}{c}B \\
\left(\mu \mathrm{g} \mathrm{L}^{-1}\right) \\
\end{array}$ & $\begin{array}{c}\text { B Rate } \\
\left(\mathrm{g} \mathrm{m}^{-2} \mathrm{~d}^{-1}\right) \\
\end{array}$ & $\begin{array}{c}\mathrm{Al} \\
\left.(\mu \mathrm{g} \mathrm{L})^{-1}\right) \\
\end{array}$ & $\begin{array}{l}\text { Al Rate } \\
\left(\mathrm{g} \mathrm{m}^{-2} \mathrm{~d}^{-1}\right) \\
\end{array}$ & $\begin{array}{c}\mathrm{Na} \\
\left(\mu g \mathrm{~L}^{-1}\right) \\
\end{array}$ & $\begin{array}{l}\text { Na Rate } \\
\left(\mathrm{g} \mathrm{m}^{-2} \mathrm{~d}^{-1}\right)\end{array}$ & $\begin{array}{c}\mathrm{Si} \\
\left(\mu \mathrm{g} \mathrm{L^{-1 } )}\right. \\
\end{array}$ & $\begin{array}{l}\text { Si Rate } \\
\left(\mathrm{g} \mathrm{m}^{-2} \mathrm{~d}^{-1}\right) \\
\end{array}$ & $\begin{array}{c}\text { IEX Rate } \\
\left(\mathrm{mol} \mathrm{m}^{-2} \mathrm{~s}^{-1}\right) \\
\end{array}$ \\
\hline BKVX-23.2 & $1.22 \mathrm{E}+05$ & $\overline{90}$ & $5.5 \mathrm{E}-05$ & 2.18 & 9.0 & 3.0076 & $6.01 \mathrm{E}-02$ & 109 & $6.55 \mathrm{E}-03$ & 162 & $2.80 \mathrm{E}-03$ & 15,694 & $9.47 \mathrm{E}-02$ & 156,174 & $4.38 \mathrm{E}-02$ & $3.52 \mathrm{E}-08$ \\
\hline BKVX-23.3 & $1.22 \mathrm{E}+05$ & 90 & $5.6 \mathrm{E}-05$ & 4.11 & 9.0 & 3.0071 & $6.01 \mathrm{E}-02$ & (32) & $1.93 \mathrm{E}-03$ & 99 & $1.24 \mathrm{E}-03$ & 7,969 & 4.72E-02 & 157,831 & $5.02 \mathrm{E}-02$ & $1.81 \mathrm{E}-08$ \\
\hline BKVX-23.4 & $1.22 \mathrm{E}+05$ & 90 & $6.2 \mathrm{E}-05$ & 5.06 & 9.0 & 3.0069 & $6.01 \mathrm{E}-02$ & (19) & $1.28 \mathrm{E}-03$ & 77 & $7.41 \mathrm{E}-04$ & 5,188 & $3.27 \mathrm{E}-02$ & 163,054 & 7.62E-02 & $1.26 \mathrm{E}-08$ \\
\hline BKVX-23.6 & $1.22 \mathrm{E}+05$ & 90 & $5.2 \mathrm{E}-05$ & 7.14 & 9.0 & 3.0068 & $6.01 \mathrm{E}-02$ & (35) & $2.03 \mathrm{E}-03$ & 76 & $6.05 \mathrm{E}-04$ & 12,534 & $7.11 \mathrm{E}-02$ & 161,714 & $6.00 \mathrm{E}-02$ & $2.76 \mathrm{E}-08$ \\
\hline BKVX-23.8 & $1.22 \mathrm{E}+05$ & 90 & $5.4 \mathrm{E}-05$ & 9.17 & 9.0 & 3.0066 & $6.01 \mathrm{E}-02$ & (18) & $1.09 \mathrm{E}-03$ & 104 & $1.33 \mathrm{E}-03$ & 4,728 & $2.59 \mathrm{E}-02$ & 158,652 & $5.15 \mathrm{E}-02$ & $9.90 \mathrm{E}-09$ \\
\hline BKVX23.10 & $1.22 \mathrm{E}+05$ & 90 & $5.6 \mathrm{E}-05$ & 11.32 & 9.0 & 3.0066 & $6.01 \mathrm{E}-02$ & (11) & $6.53 \mathrm{E}-04$ & 84 & 8.49E-04 & 4,025 & $2.23 \mathrm{E}-02$ & 162,903 & $6.85 \mathrm{E}-02$ & 8.64E-09 \\
\hline BKVX23.14 & $1.22 \mathrm{E}+05$ & 90 & $6.7 \mathrm{E}-05$ & 14.97 & 9.0 & 3.0065 & $6.01 \mathrm{E}-02$ & ND & - & 54 & $1.07 \mathrm{E}-04$ & 2,940 & $1.85 \mathrm{E}-02$ & 156,050 & $5.27 \mathrm{E}-02$ & 0.00 \\
\hline BKVX23.16 & $1.22 \mathrm{E}+05$ & 90 & $5.5 \mathrm{E}-05$ & 17.29 & 9.0 & 3.0065 & $6.01 \mathrm{E}-02$ & (3) & $1.99 \mathrm{E}-04$ & 75 & $6.10 \mathrm{E}-04$ & 2,501 & $1.24 \mathrm{E}-02$ & 161,250 & $6.11 \mathrm{E}-02$ & $4.86 \mathrm{E}-09$ \\
\hline $\begin{array}{c}\text { BKVX23.18 } \\
\text { Exp. \#67 }\end{array}$ & $1.22 \mathrm{E}+05$ & 90 & $5.8 \mathrm{E}-05$ & 18.92 & 9.0 & 3.0065 & $6.01 \mathrm{E}-02$ & (22) & $1.40 \mathrm{E}-03$ & 110 & $1.58 \mathrm{E}-03$ & 3,244 & $1.81 \mathrm{E}-02$ & 163,081 & $7.21 \mathrm{E}-02$ & 6.67E-09 \\
\hline BKVX-24A & $1.39 \mathrm{E}+05$ & 90 & - & - & 9.0 & - & - & (0) & - & $<50$ & - & $<500$ & - & 156,189 & - & - \\
\hline BKVX-24B & $1.39 \mathrm{E}+05$ & 90 & - & - & 9.0 & - & - & $(0)$ & - & $<50$ & - & $<500$ & - & 161,855 & - & - \\
\hline BKVX-24C & $1.39 \mathrm{E}+05$ & 90 & - & - & 9.0 & - & - & (0) & - & $<50$ & - & $<500$ & - & 159,634 & - & - \\
\hline BKVX-24.2 & $1.39 \mathrm{E}+05$ & 90 & $5.7 \mathrm{E}-05$ & 2.18 & 9.0 & 3.0058 & $6.01 \mathrm{E}-02$ & (51) & $3.19 \mathrm{E}-03$ & 94 & $1.13 \mathrm{E}-03$ & 10,869 & $6.68 \mathrm{E}-02$ & 178,580 & $7.05 \mathrm{E}-02$ & $2.54 \mathrm{E}-08$ \\
\hline BKVX-24.4 & $1.39 \mathrm{E}+05$ & 90 & $5.2 \mathrm{E}-05$ & 5.06 & 9.0 & 3.0054 & $6.01 \mathrm{E}-02$ & (11) & $6.20 \mathrm{E}-04$ & 59 & $2.04 \mathrm{E}-04$ & 6,402 & $3.45 \mathrm{E}-02$ & 176,252 & $5.63 \mathrm{E}-02$ & $1.35 \mathrm{E}-08$ \\
\hline BKVX-24.6 & $1.39 \mathrm{E}+05$ & 90 & $5.7 \mathrm{E}-05$ & 7.14 & 9.0 & 3.0053 & $6.01 \mathrm{E}-02$ & (26) & $1.65 \mathrm{E}-03$ & 76 & $6.62 \mathrm{E}-04$ & 12,119 & $7.51 \mathrm{E}-02$ & 195,370 & $1.32 \mathrm{E}-01$ & $2.93 \mathrm{E}-08$ \\
\hline BKVX-24.8 & $1.39 \mathrm{E}+05$ & 90 & $4.9 \mathrm{E}-05$ & 9.17 & 9.0 & 3.0053 & $6.01 \mathrm{E}-02$ & (4) & $1.96 \mathrm{E}-04$ & 58 & $1.83 \mathrm{E}-04$ & 5,082 & $2.56 \mathrm{E}-02$ & 193,239 & $1.08 \mathrm{E}-01$ & $1.02 \mathrm{E}-08$ \\
\hline BKVX24.10 & $1.39 \mathrm{E}+05$ & 90 & $5.6 \mathrm{E}-05$ & 11.32 & 9.0 & 3.0052 & $6.01 \mathrm{E}-02$ & (1) & $6.47 \mathrm{E}-05$ & (39) & 0.00 & 6,873 & $4.02 \mathrm{E}-02$ & 168,783 & $3.41 \mathrm{E}-02$ & $1.60 \mathrm{E}-08$ \\
\hline BKVX24.12 & $1.39 \mathrm{E}+05$ & 90 & $5.3 \mathrm{E}-05$ & 13.12 & 9.0 & 3.0049 & $6.02 \mathrm{E}-02$ & $<100$ & $5.79 \mathrm{E}-03$ & (31) & 0.00 & 7,463 & 4.17E-02 & 167,027 & $2.64 \mathrm{E}-02$ & $1.43 \mathrm{E}-08$ \\
\hline BKVX24.14 & $1.39 \mathrm{E}+05$ & 90 & $6.3 \mathrm{E}-05$ & 14.97 & 9.0 & 3.0044 & $6.02 \mathrm{E}-02$ & $<100$ & $6.86 \mathrm{E}-03$ & (27) & 0.00 & 6,069 & $3.95 \mathrm{E}-02$ & 179,573 & $8.16 \mathrm{E}-02$ & $1.30 \mathrm{E}-08$ \\
\hline BKVX24.16 & $1.39 \mathrm{E}+05$ & 90 & $5.8 \mathrm{E}-05$ & 17.29 & 9.0 & 3.0037 & $6.02 \mathrm{E}-02$ & $<100$ & $6.29 \mathrm{E}-03$ & (40) & 0.00 & 3,011 & $1.63 \mathrm{E}-02$ & 182,382 & $8.52 \mathrm{E}-02$ & 4.00E-09 \\
\hline BKVX24.18 & $1.39 \mathrm{E}+05$ & 90 & $5.6 \mathrm{E}-05$ & 18.92 & 9.0 & 3.0031 & $6.02 \mathrm{E}-02$ & $<100$ & $6.12 \mathrm{E}-03$ & 62 & $2.98 \mathrm{E}-04$ & 3,054 & $1.61 \mathrm{E}-02$ & 193,396 & $1.22 \mathrm{E}-01$ & 4.00E-09 \\
\hline
\end{tabular}

\section{Foam}

\begin{tabular}{|c|c|c|c|c|c|c|c|c|c|c|c|c|c|c|c|c|}
\hline Exp. \#68 & & & & & & & & & & & & & & & & \\
\hline BKV3-1A & $8.97 \mathrm{E}+02$ & 23 & - & - & 9.0 & - & - & $(0)$ & - & $<25$ & - & $(100)$ & - & $<1000$ & - & - \\
\hline BKV3-1.1 & $8.97 \mathrm{E}+02$ & 23 & $4.8 \mathrm{E}-06$ & 2.11 & 9.0 & 4.0139 & $8.03 \mathrm{E}-02$ & 244 & $8.51 \mathrm{E}-04$ & 244 & $2.75 \mathrm{E}-04$ & 3,576 & $1.19 \mathrm{E}-03$ & 1,378 & $1.05 \mathrm{E}-04$ & $1.34 \mathrm{E}-10$ \\
\hline BKV3-1.2 & $8.97 \mathrm{E}+02$ & 23 & $4.8 \mathrm{E}-06$ & 4.15 & 9.0 & 4.0136 & 8.03E-02 & 373 & $1.30 \mathrm{E}-03$ & 409 & $4.83 \mathrm{E}-04$ & 4,393 & $1.46 \mathrm{E}-03$ & 2,297 & $3.59 \mathrm{E}-04$ & $6.57 \mathrm{E}-11$ \\
\hline BKV3-1.4 & $8.97 \mathrm{E}+02$ & 23 & $9.7 \mathrm{E}-06$ & 6.14 & 9.0 & 4.0128 & $8.02 \mathrm{E}-02$ & 306 & $2.16 \mathrm{E}-03$ & 381 & $9.05 \mathrm{E}-04$ & 3,072 & $2.05 \mathrm{E}-03$ & 1,998 & $5.58 \mathrm{E}-04$ & 0.00 \\
\hline BKV3-1.5 & $8.97 \mathrm{E}+02$ & 23 & $9.4 \mathrm{E}-06$ & 7.24 & 9.0 & 4.0125 & $8.02 \mathrm{E}-02$ & 269 & $1.84 \mathrm{E}-03$ & 361 & $8.29 \mathrm{E}-04$ & 2,723 & $1.75 \mathrm{E}-03$ & 1,863 & 4.69E-04 & 0.00 \\
\hline BKV3-1.6 & $8.97 \mathrm{E}+02$ & 23 & $1.0 \mathrm{E}-05$ & 8.07 & 9.0 & 4.0123 & $8.02 \mathrm{E}-02$ & 231 & $1.69 \mathrm{E}-03$ & 338 & $8.28 \mathrm{E}-04$ & 2,621 & $1.81 \mathrm{E}-03$ & 1,710 & $4.14 \mathrm{E}-04$ & $4.67 \mathrm{E}-11$ \\
\hline BKV3-1.16 & $8.97 \mathrm{E}+02$ & 23 & $9.7 \mathrm{E}-06$ & 36.97 & 9.0 & 4.0121 & $8.02 \mathrm{E}-02$ & (74) & $5.22 \mathrm{E}-04$ & 168 & $3.64 \mathrm{E}-04$ & $(680)$ & $4.00 \mathrm{E}-04$ & $(880)$ & 0.00 & 0.00 \\
\hline
\end{tabular}


Table B1. SPFT Temperature Sweep, Experimental Conditions, and Dissolution Rates. Data in parenthesis are near quantification limit.

\begin{tabular}{|c|c|c|c|c|c|c|c|c|c|c|c|c|c|c|c|c|}
\hline$\underline{\text { Sample ID }}$ & $\begin{array}{l}\text { Influent Si } \\
\qquad \underline{\left(\mu g L^{-1}\right)}\end{array}$ & $\frac{\mathrm{T}}{\left({ }^{\circ} \mathrm{C}\right)}$ & $\begin{array}{l}\text { Flow Rate } \\
\underline{\left(\mathrm{m}^{3} / \mathrm{day}\right)}\end{array}$ & $\begin{array}{l}\text { Time } \\
\text { (days) } \\
\end{array}$ & $\begin{array}{c}\mathrm{pH} \\
\left(23^{\circ} \mathrm{C}\right) \\
\end{array}$ & Mass & $\begin{array}{l}\text { Sur. Area } \\
\qquad \underline{\left(\mathrm{m}^{2}\right)}\end{array}$ & $\begin{array}{c}\text { B } \\
\left(\mu \mathrm{g} \mathrm{L}{ }^{-1}\right) \\
\end{array}$ & $\begin{array}{c}\text { B Rate } \\
\left(\mathrm{g} \mathrm{m}^{-2} \mathrm{~d}^{-1}\right) \\
\end{array}$ & $\begin{array}{c}\mathrm{Al} \\
\left(\mu \mathrm{g} \mathrm{L}^{-1}\right) \\
\end{array}$ & $\begin{array}{c}\text { Al Rate } \\
\left(\mathrm{g} \mathrm{m}^{-2} \mathrm{~d}^{-1}\right) \\
\end{array}$ & $\begin{array}{c}\mathrm{Na} \\
\left(\mu \mathrm{g} \mathrm{L}^{-1}\right) \\
\end{array}$ & $\begin{array}{l}\text { Na Rate } \\
\left(\mathrm{g} \mathrm{m}^{-2} \mathrm{~d}^{-1}\right) \\
\end{array}$ & $\begin{array}{c}\mathrm{Si} \\
\left(\mu g \mathrm{~L}^{-1}\right) \\
\end{array}$ & $\begin{array}{l}\text { Si Rate } \\
\left(\mathrm{g} \mathrm{m}^{-2} \mathrm{~d}^{-1}\right)\end{array}$ & $\begin{array}{l}\text { IEX Rate } \\
\underline{\left(\mathrm{mol} \mathrm{m}^{-2} \mathrm{~s}^{-1}\right)}\end{array}$ \\
\hline BKV3-1.17 & $8.97 \mathrm{E}+02$ & 23 & $9.5 \mathrm{E}-06$ & 39.93 & 9.0 & 4.0119 & $8.02 \mathrm{E}-02$ & (67) & $4.63 \mathrm{E}-04$ & 168 & $3.59 \mathrm{E}-04$ & (706) & 4.12E-04 & $(867)$ & 0.00 & 0.00 \\
\hline BKV3-1.18 & $8.97 \mathrm{E}+02$ & 23 & $9.6 \mathrm{E}-06$ & 44.86 & 9.0 & 4.0116 & $8.02 \mathrm{E}-02$ & $(60)$ & 4.24E-04 & 162 & $3.47 \mathrm{E}-04$ & (597) & $3.41 \mathrm{E}-04$ & (809) & 0.00 & 0.00 \\
\hline $\begin{array}{c}\text { BKV3-1.19 } \\
\text { Exp.\#69 }\end{array}$ & $8.97 \mathrm{E}+02$ & 23 & $9.9 \mathrm{E}-06$ & 47.01 & 9.0 & 4.0115 & $8.02 \mathrm{E}-02$ & (60) & 4.34E-04 & 170 & $3.77 \mathrm{E}-04$ & $(625)$ & $3.70 \mathrm{E}-04$ & $(824)$ & 0.00 & 0.00 \\
\hline BKV3-2A & $5.24 \mathrm{E}+04$ & 23 & - & - & 9.0 & - & - & $(0)$ & - & $<25$ & - & $(100)$ & - & 83,641 & - & - \\
\hline BKV3-2.1 & $5.24 \mathrm{E}+04$ & 23 & $4.9 \mathrm{E}-06$ & 2.11 & 9.0 & 4.0149 & 8.03E-02 & 184 & $6.58 \mathrm{E}-04$ & 32 & $8.48 \mathrm{E}-06$ & 3,996 & $1.36 \mathrm{E}-03$ & 94,998 & $3.23 \mathrm{E}-03$ & $2.82 \mathrm{E}-10$ \\
\hline BKV3-2.3 & $5.24 \mathrm{E}+04$ & 23 & $2.1 \mathrm{E}-05$ & 4.90 & 9.0 & 4.0145 & 8.03E-02 & 193 & $2.93 \mathrm{E}-03$ & 38 & $7.06 \mathrm{E}-05$ & 3,481 & $5.04 \mathrm{E}-03$ & 85,104 & $1.77 \mathrm{E}-03$ & $8.42 \mathrm{E}-10$ \\
\hline BKV3-2.4 & $5.24 \mathrm{E}+04$ & 23 & $9.9 \mathrm{E}-06$ & 6.14 & 9.0 & 4.0143 & $8.03 \mathrm{E}-02$ & 143 & $1.04 \mathrm{E}-03$ & 32 & $1.74 \mathrm{E}-05$ & 2,681 & $1.83 \mathrm{E}-03$ & 81,350 & 0.00 & $3.17 \mathrm{E}-10$ \\
\hline BKV3-2.5 & $5.24 \mathrm{E}+04$ & 23 & $9.5 \mathrm{E}-06$ & 7.24 & 9.0 & 4.0141 & $8.03 \mathrm{E}-02$ & 125 & $8.66 \mathrm{E}-04$ & 31 & $1.53 \mathrm{E}-05$ & 2,306 & $1.50 \mathrm{E}-03$ & 80,433 & 0.00 & $2.53 \mathrm{E}-10$ \\
\hline BKV3-2.6 & $5.24 \mathrm{E}+04$ & 23 & $1.0 \mathrm{E}-05$ & 8.07 & 9.0 & 4.0140 & $8.03 \mathrm{E}-02$ & 127 & $9.37 \mathrm{E}-04$ & 30 & $1.37 \mathrm{E}-05$ & 2,089 & $1.44 \mathrm{E}-03$ & 79,683 & 0.00 & $2.01 \mathrm{E}-10$ \\
\hline BKV3-2.16 & $5.24 \mathrm{E}+04$ & 23 & $9.7 \mathrm{E}-06$ & 36.97 & 9.0 & 4.0139 & 8.03E-02 & (29) & $2.04 \mathrm{E}-04$ & 23 & 0.00 & (543) & $3.06 \mathrm{E}-04$ & 77881 & 0.00 & $4.09 \mathrm{E}-11$ \\
\hline BKV3-2.17 & $5.24 \mathrm{E}+04$ & 23 & $9.5 \mathrm{E}-06$ & 39.93 & 9.0 & 4.0139 & 8.03E-02 & (20) & $1.37 \mathrm{E}-04$ & 29 & $9.06 \mathrm{E}-06$ & (501) & $2.72 \mathrm{E}-04$ & 77824 & 0.00 & $5.35 \mathrm{E}-11$ \\
\hline BKV3-2.18 & $5.24 \mathrm{E}+04$ & 23 & $9.6 \mathrm{E}-06$ & 44.86 & 9.0 & 4.0138 & $8.03 \mathrm{E}-02$ & (13) & $9.28 \mathrm{E}-05$ & 25 & $6.47 \mathrm{E}-07$ & $(441)$ & $2.34 \mathrm{E}-04$ & 77913 & 0.00 & $5.63 \mathrm{E}-11$ \\
\hline $\begin{array}{c}\text { BKV3-2.19 } \\
\text { Exp.\#70 }\end{array}$ & $5.24 \mathrm{E}+04$ & 23 & $9.8 \mathrm{E}-06$ & 47.01 & 9.0 & 4.0138 & 8.03E-02 & (11) & 7.65E-05 & 26 & $2.62 \mathrm{E}-06$ & (441) & 2.39E-04 & 77731 & 0.00 & $6.51 \mathrm{E}-11$ \\
\hline BKV3-3A & $8.79 \mathrm{E}+02$ & 90 & - & - & & - & - & $<100$ & - & $<25$ & - & $<1000$ & - & $<1000$ & - & - \\
\hline BKV3-3.2 & $8.79 \mathrm{E}+02$ & 90 & $5.3 \mathrm{E}-05$ & 0.81 & 9.0 & 1.0330 & $2.07 \mathrm{E}-02$ & (5) & - & 5 & - & (108) & - & $(88)$ & - & $4.39 \mathrm{E}-10$ \\
\hline BKV3-3.4 & $8.79 \mathrm{E}+02$ & 90 & $4.1 \mathrm{E}-05$ & 2.05 & 9.0 & 1.0317 & $2.06 \mathrm{E}-02$ & 547 & $5.21 \mathrm{E}-02$ & 1,357 & $5.61 \mathrm{E}-02$ & 6,169 & $5.91 \mathrm{E}-02$ & 6,882 & $5.46 \mathrm{E}-02$ & $2.78 \mathrm{E}-09$ \\
\hline BKV3-3.6 & $8.79 \mathrm{E}+02$ & 90 & $4.8 \mathrm{E}-05$ & 4.79 & 9.0 & 1.0293 & $2.06 \mathrm{E}-02$ & 669 & 7.83E-02 & 2,060 & $1.01 \mathrm{E}-01$ & 6,061 & $6.82 \mathrm{E}-02$ & 9,956 & $9.79 \mathrm{E}-02$ & 0.00 \\
\hline BKV3-3.8 & $8.79 \mathrm{E}+02$ & 90 & $5.4 \mathrm{E}-05$ & 6.84 & 9.0 & 1.0266 & $2.05 \mathrm{E}-02$ & 647 & $8.37 \mathrm{E}-02$ & 1,982 & $1.08 \mathrm{E}-01$ & 5,854 & $7.28 \mathrm{E}-02$ & 9,607 & $1.05 \mathrm{E}-01$ & 0.00 \\
\hline BKV3-3.10 & $8.79 \mathrm{E}+02$ & 90 & $9.2 \mathrm{E}-05$ & 8.94 & 9.0 & 1.0231 & $2.05 \mathrm{E}-02$ & 653 & $1.45 \mathrm{E}-01$ & 2,116 & $1.98 \mathrm{E}-01$ & 5,920 & $1.27 \mathrm{E}-01$ & 9,960 & $1.87 \mathrm{E}-01$ & 0.00 \\
\hline $\begin{array}{c}\text { BKV3-3.12 } \\
\text { Exp. \#71 }\end{array}$ & $8.79 \mathrm{E}+02$ & 90 & $5.4 \mathrm{E}-05$ & 10.70 & 9.0 & 1.0203 & $2.04 \mathrm{E}-02$ & 740 & $9.82 \mathrm{E}-02$ & 2,330 & $1.28 \mathrm{E}-01$ & 6,721 & $8.61 \mathrm{E}-02$ & 11,094 & $1.23 \mathrm{E}-01$ & 0.00 \\
\hline BKV3-4A & $1.39 \mathrm{E}+05$ & 90 & - & - & 9.0 & - & - & $(0)$ & - & $<25$ & - & $<1000$ & - & 161,536 & - & - \\
\hline BKV3-4.2 & $1.39 \mathrm{E}+05$ & 90 & $4.1 \mathrm{E}-05$ & 0.81 & 9.0 & 3.0913 & $6.18 \mathrm{E}-02$ & 361 & $1.39 \mathrm{E}-02$ & 81 & $7.83 \mathrm{E}-04$ & 13,548 & $4.73 \mathrm{E}-02$ & 180,275 & $5.49 \mathrm{E}-01$ & $1.33 \mathrm{E}-08$ \\
\hline BKV3-4.4 & $1.39 \mathrm{E}+05$ & 90 & $4.1 \mathrm{E}-05$ & 2.05 & 9.0 & 3.0907 & $6.18 \mathrm{E}-02$ & 104 & $4.00 \mathrm{E}-03$ & 102 & $1.08 \mathrm{E}-03$ & 8,685 & $2.90 \mathrm{E}-02$ & 192,400 & $5.86 \mathrm{E}-01$ & $9.98 \mathrm{E}-09$ \\
\hline BKV3-4.6 & $1.39 \mathrm{E}+05$ & 90 & $4.9 \mathrm{E}-05$ & 4.79 & 9.0 & 3.0904 & $6.18 \mathrm{E}-02$ & (63) & $2.91 \mathrm{E}-03$ & 92 & $1.12 \mathrm{E}-03$ & 7,291 & $2.87 \mathrm{E}-02$ & 202,952 & $7.47 \mathrm{E}-01$ & $1.03 \mathrm{E}-08$ \\
\hline BKV3-4.8 & $1.39 \mathrm{E}+05$ & 90 & $5.9 \mathrm{E}-05$ & 6.84 & 9.0 & 3.0902 & $6.18 \mathrm{E}-02$ & (31) & $1.73 \mathrm{E}-03$ & 91 & $1.33 \mathrm{E}-03$ & 4,914 & $2.14 \mathrm{E}-02$ & 176,142 & 7.77E-01 & $7.86 \mathrm{E}-09$ \\
\hline BKV3-4.10 & $1.39 \mathrm{E}+05$ & 90 & $9.1 \mathrm{E}-05$ & 8.94 & 9.0 & 3.0901 & $6.18 \mathrm{E}-02$ & (24) & $2.02 \mathrm{E}-03$ & 121 & $2.98 \mathrm{E}-03$ & 4,364 & $2.83 \mathrm{E}-02$ & 187,733 & $1.28 \mathrm{E}+00$ & $1.05 \mathrm{E}-08$ \\
\hline BKV3-4.12 & $1.39 \mathrm{E}+05$ & 90 & $5.1 \mathrm{E}-05$ & 10.70 & 9.0 & 3.0900 & $6.18 \mathrm{E}-02$ & (11) & $5.47 \mathrm{E}-04$ & 94 & $1.19 \mathrm{E}-03$ & 3,984 & $1.40 \mathrm{E}-02$ & 217,334 & $8.26 \mathrm{E}-01$ & 5.39E-09 \\
\hline BKV3-4.19 & $1.39 \mathrm{E}+05$ & 90 & $5.4 \mathrm{E}-05$ & 18.74 & 9.0 & 3.0900 & $6.18 \mathrm{E}-02$ & (14) & $7.30 \mathrm{E}-04$ & 81 & $1.04 \mathrm{E}-03$ & $(3,144)$ & $1.08 \mathrm{E}-02$ & \#\#\#\#\# & $6.60 \mathrm{E}-01$ & 4.04E-09 \\
\hline BKV3-4.21 & $1.39 \mathrm{E}+05$ & 90 & $3.7 \mathrm{E}-05$ & 20.71 & 9.0 & 3.0899 & $6.18 \mathrm{E}-02$ & (27) & $9.28 \mathrm{E}-04$ & 210 & $2.32 \mathrm{E}-03$ & $(3,313)$ & $7.88 \mathrm{E}-03$ & 166307 & $4.57 \mathrm{E}-01$ & $2.78 \mathrm{E}-09$ \\
\hline
\end{tabular}


Table B1. SPFT Temperature Sweep, Experimental Conditions, and Dissolution Rates. Data in parenthesis are near quantification limit.

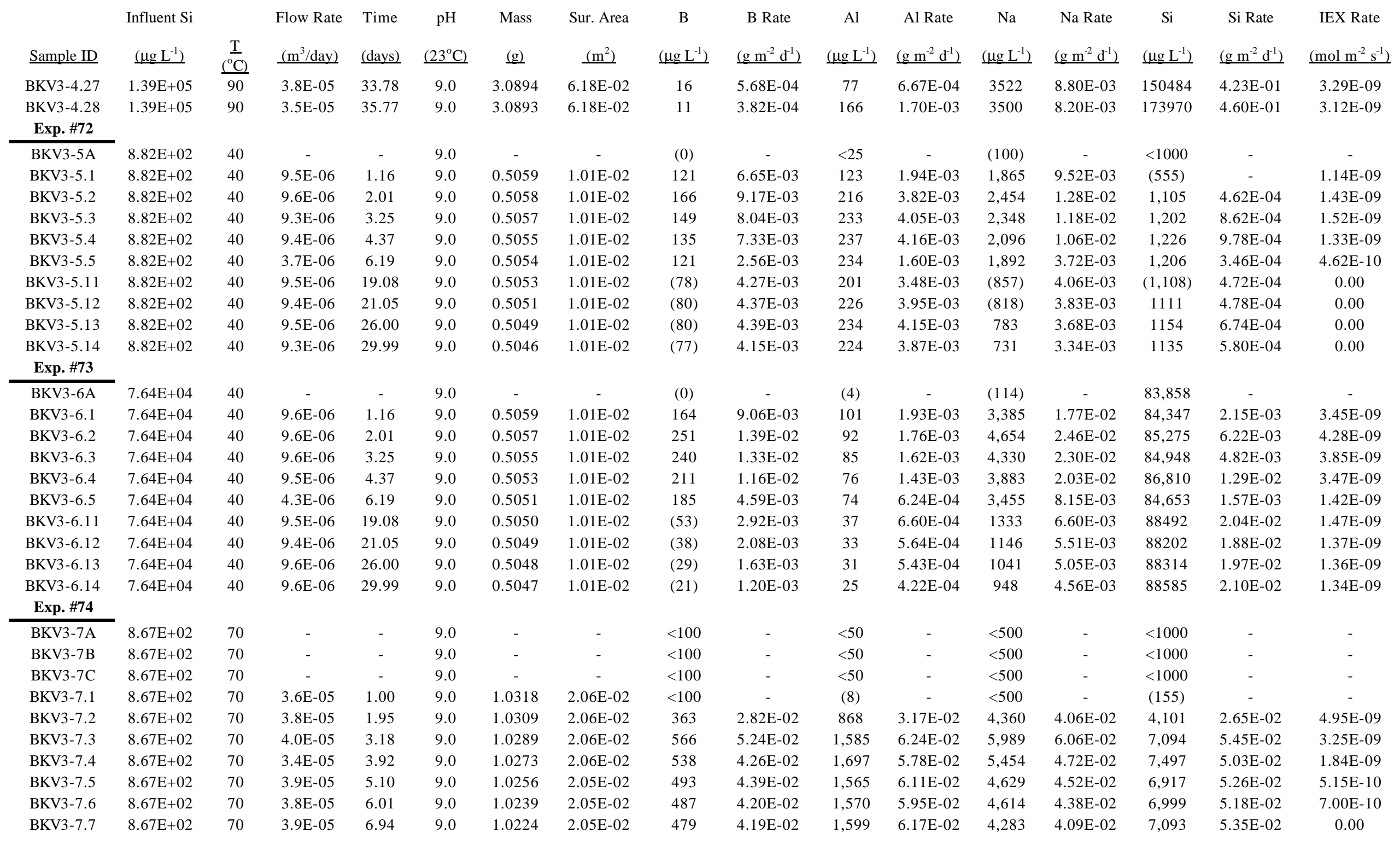


Table B1. SPFT Temperature Sweep, Experimental Conditions, and Dissolution Rates. Data in parenthesis are near quantification limit.

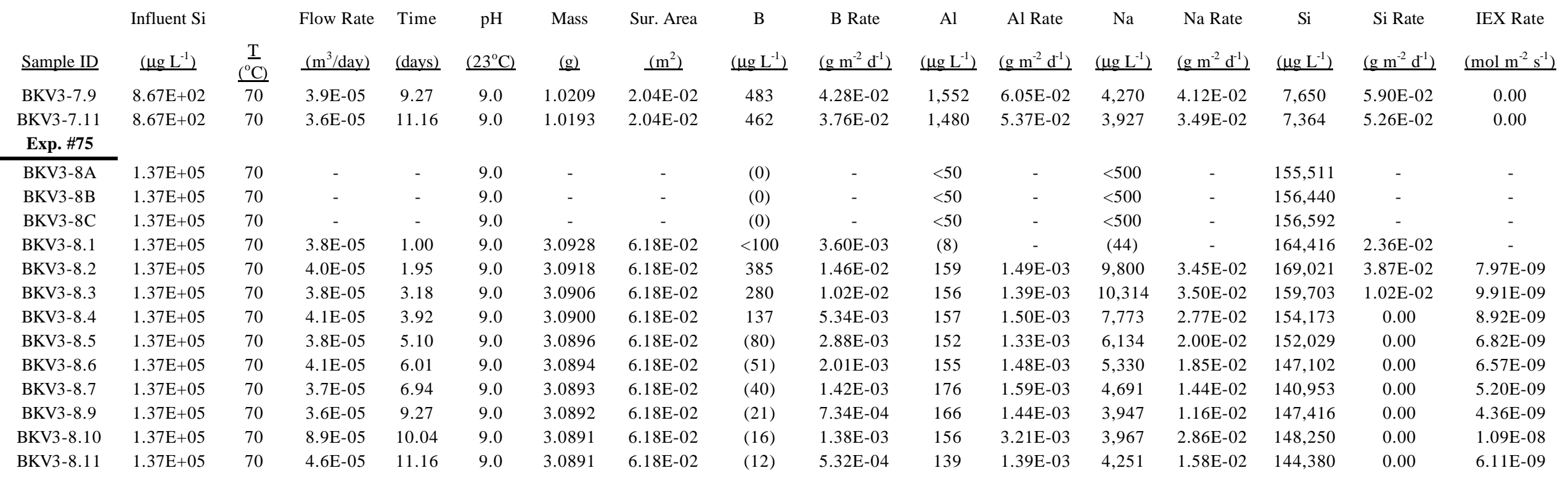

\section{Large Scale Test \#2}

\section{Centerline}

\begin{tabular}{|c|c|c|c|c|c|c|c|c|c|c|c|c|c|c|c|c|}
\hline Sample ID & $\begin{array}{l}\text { Influent } \mathrm{Si} \\
\quad\left(\mu \mathrm{g} \mathrm{L}^{-1}\right)\end{array}$ & $\begin{array}{l}\text { Temp } \\
.\left({ }^{\circ} \mathrm{C}\right)\end{array}$ & $\begin{array}{l}\text { Flow Rate } \\
\left(\mathrm{m}^{3} / \text { day }\right)\end{array}$ & $\begin{array}{l}\text { Dura- } \\
\text { tion } \\
\text { (days) }\end{array}$ & $\begin{array}{c}\mathrm{pH} \\
\left(23^{\circ} \mathrm{C}\right)\end{array}$ & $\begin{array}{c}\text { Glass } \\
\text { Mass } \\
(\mathrm{g})\end{array}$ & $\begin{array}{l}\text { Surf. Area } \\
\qquad\left(\mathrm{m}^{2}\right)\end{array}$ & $\begin{array}{c}\mathrm{B} \\
\left(\mu \mathrm{g} \mathrm{L}^{-1}\right)\end{array}$ & $\begin{array}{c}\text { B Rate } \\
\left(\mathrm{g} \mathrm{m}^{-2} \mathrm{~d}^{-1}\right)\end{array}$ & $\begin{array}{c}\mathrm{Al} \\
\left(\mu \mathrm{g} \mathrm{L}^{-1}\right)\end{array}$ & $\begin{array}{c}\text { Al Rate } \\
\left(\mathrm{g} \mathrm{m}^{-2} \mathrm{~d}^{-1}\right)\end{array}$ & $\begin{array}{c}\mathrm{Na} \\
\left(\mu \mathrm{g} \mathrm{L}^{-1}\right)\end{array}$ & $\begin{array}{l}\text { Na Rate } \\
\left(\mathrm{g} \mathrm{m}^{-2} \mathrm{~d}^{-1}\right)\end{array}$ & $\begin{array}{c}\mathrm{Si} \\
\left(\mu \mathrm{g} \mathrm{L}^{-1}\right)\end{array}$ & $\begin{array}{l}\text { Si Rate } \\
\left(\mathrm{g} \mathrm{m}^{-2} \mathrm{~d}^{-1}\right)\end{array}$ & $\begin{array}{c}\text { IEX Rate } \\
\left(\mathrm{mol} \mathrm{m}^{-2} \mathrm{~s}^{-1}\right)\end{array}$ \\
\hline
\end{tabular}

\begin{tabular}{|c|c|c|c|c|c|c|c|c|c|c|c|c|c|c|c|c|}
\hline Exp. \#76 & & & & & & & & & & & & & & & & \\
\hline BKV4-1A & $8.79 \mathrm{E}+02$ & 90 & - & - & 9.0 & - & - & (50) & - & $<25$ & - & $(500)$ & - & $<1000$ & - & - \\
\hline BKV4-1.2 & $8.79 \mathrm{E}+02$ & 90 & $4.9 \mathrm{E}-05$ & 1.93 & 9.0 & 1.0022 & $2.95 \mathrm{E}-02$ & 265 & $1.95 \mathrm{E}-02$ & 811 & $3.03 \mathrm{E}-02$ & 1,793 & $1.96 \mathrm{E}-02$ & 5,195 & $2.76 \mathrm{E}-02$ & $2.80 \mathrm{E}-11$ \\
\hline BKV4-1.3 & $8.79 \mathrm{E}+02$ & 90 & $6.1 \mathrm{E}-05$ & 2.84 & 9.0 & 1.0004 & $2.95 \mathrm{E}-02$ & 467 & $4.71 \mathrm{E}-02$ & 1,375 & $6.48 \mathrm{E}-02$ & 2,733 & $4.21 \mathrm{E}-02$ & 8,659 & $6.27 \mathrm{E}-02$ & 0.00 \\
\hline BKV4-1.4 & $8.79 \mathrm{E}+02$ & 90 & $5.3 \mathrm{E}-05$ & 3.69 & 9.0 & 0.9984 & $2.94 \mathrm{E}-02$ & 506 & $4.43 \mathrm{E}-02$ & 1,473 & $5.98 \mathrm{E}-02$ & 2,889 & $3.87 \mathrm{E}-02$ & 9,209 & $5.79 \mathrm{E}-02$ & 0.00 \\
\hline BKV4-1.5 & $8.79 \mathrm{E}+02$ & 90 & $5.4 \mathrm{E}-05$ & 4.94 & 9.0 & 0.9958 & $2.94 \mathrm{E}-02$ & 547 & 4.99E-02 & 1,599 & $6.71 \mathrm{E}-02$ & 3,175 & $4.48 \mathrm{E}-02$ & 10,008 & $6.56 \mathrm{E}-02$ & 0.00 \\
\hline BKV4-1.6 & $8.79 \mathrm{E}+02$ & 90 & $5.4 \mathrm{E}-05$ & 6.06 & 9.0 & 0.9929 & $2.93 \mathrm{E}-02$ & 565 & $5.20 \mathrm{E}-02$ & 1,654 & $6.99 \mathrm{E}-02$ & 3,113 & $4.40 \mathrm{E}-02$ & 10,382 & $6.87 \mathrm{E}-02$ & 0.00 \\
\hline BKV4-1.7 & $8.79 \mathrm{E}+02$ & 90 & $5.5 \mathrm{E}-05$ & 6.70 & 9.0 & 0.9909 & $2.92 \mathrm{E}-02$ & 544 & $5.06 \mathrm{E}-02$ & 1,122 & $4.78 \mathrm{E}-02$ & 2,855 & $4.03 \mathrm{E}-02$ & 10,456 & $7.03 \mathrm{E}-02$ & 0.00 \\
\hline BKV4-2A & $3.74 \mathrm{E}+04$ & 90 & - & - & 9.0 & - & - & $(50)$ & - & $<25$ & - & $(500)$ & - & 44,927 & - & - \\
\hline
\end{tabular}


Table B1. SPFT Temperature Sweep, Experimental Conditions, and Dissolution Rates. Data in parenthesis are near quantification limit.

\begin{tabular}{|c|c|c|c|c|c|c|c|c|c|c|c|c|c|c|c|c|}
\hline & Influent $\mathrm{Si}$ & & Flow Rate & Time & $\mathrm{pH}$ & Mass & Sur. Area & B & B Rate & $\mathrm{Al}$ & Al Rate & $\mathrm{Na}$ & Na Rate & $\mathrm{Si}$ & Si Rate & IEX Rate \\
\hline$\underline{\text { Sample ID }}$ & $\underline{\left(\mu \mathrm{L}^{-1}\right)}$ & $\frac{\mathrm{T}}{\left({ }^{\circ} \mathrm{C}\right)}$ & $\left(\mathrm{m}^{3} / \mathrm{day}\right)$ & $\underline{\text { (days) }}$ & $\underline{\left(23^{\circ} \mathrm{C}\right)}$ & $\underline{(\mathrm{g})}$ & $\underline{\left(\mathrm{m}^{2}\right)}$ & $\underline{\left(\mu g L^{-1}\right)}$ & $\underline{\left(\mathrm{g} \mathrm{m}^{-2} \mathrm{~d}^{-1}\right)}$ & $\underline{\left(\mu \mathrm{g} \mathrm{L}^{-1}\right)}$ & $\underline{\left(\mathrm{g} \mathrm{m}^{-2} \mathrm{~d}^{-1}\right)}$ & $\underline{\left(\mu g \mathrm{~L}^{-1}\right)}$ & $\underline{\left(\mathrm{g} \mathrm{m}^{-2} \mathrm{~d}^{-1}\right)}$ & $\underline{\left(\mu \mathrm{g} \mathrm{L}^{-1}\right)}$ & $\underline{\left(\mathrm{g} \mathrm{m}^{-2} \mathrm{~d}^{-1}\right)}$ & $\underline{\left(\mathrm{mol} \mathrm{m} \mathrm{m}^{-2} \mathrm{~s}^{-1}\right)}$ \\
\hline BKV4-2.2 & $3.74 \mathrm{E}+04$ & 90 & $5.2 \mathrm{E}-05$ & 1.93 & 9.0 & 1.0048 & $2.96 \mathrm{E}-02$ & (58) & $7.92 \mathrm{E}-04$ & 161 & $5.54 \mathrm{E}-03$ & (797) & $4.76 \mathrm{E}-03$ & 46,826 & $1.32 \mathrm{E}-02$ & $1.59 \mathrm{E}-09$ \\
\hline BKV4-2.3 & $3.74 \mathrm{E}+04$ & 90 & $5.9 \mathrm{E}-05$ & 2.84 & 9.0 & 1.0044 & $2.96 \mathrm{E}-02$ & (93) & 4.65E-03 & 284 & $1.19 \mathrm{E}-02$ & 1,356 & $1.55 \mathrm{E}-02$ & 47,336 & $1.89 \mathrm{E}-02$ & 4.33E-09 \\
\hline BKV4-2.4 & $3.74 \mathrm{E}+04$ & 90 & $6.4 \mathrm{E}-05$ & 3.69 & 9.0 & 1.0040 & $2.96 \mathrm{E}-02$ & 117 & $7.88 \mathrm{E}-03$ & 356 & $1.66 \mathrm{E}-02$ & 1,413 & $1.80 \mathrm{E}-02$ & 47,540 & $2.24 \mathrm{E}-02$ & 4.04E-09 \\
\hline BKV4-2.5 & $3.74 \mathrm{E}+04$ & 90 & $5.5 \mathrm{E}-05$ & 4.94 & 9.0 & 1.0032 & $2.96 \mathrm{E}-02$ & 148 & $9.98 \mathrm{E}-03$ & 445 & $1.81 \mathrm{E}-02$ & 1,535 & $1.75 \mathrm{E}-02$ & 47,417 & $1.83 \mathrm{E}-02$ & $3.01 \mathrm{E}-09$ \\
\hline BKV4-2.6 & $3.74 \mathrm{E}+04$ & 90 & $5.8 \mathrm{E}-05$ & 6.06 & 9.0 & 1.0024 & $2.95 \mathrm{E}-02$ & 158 & $1.15 \mathrm{E}-02$ & 469 & $2.01 \mathrm{E}-02$ & 1,477 & $1.73 \mathrm{E}-02$ & 47,201 & $1.75 \mathrm{E}-02$ & 2.32E-09 \\
\hline BKV4-2.7 & $3.74 \mathrm{E}+04$ & 90 & $4.5 \mathrm{E}-05$ & 6.70 & 9.0 & 1.0019 & $2.95 \mathrm{E}-02$ & 133 & $6.92 \mathrm{E}-03$ & 406 & $1.35 \mathrm{E}-02$ & 1,178 & $9.42 \mathrm{E}-03$ & 46,855 & $1.16 \mathrm{E}-02$ & $9.96 \mathrm{E}-10$ \\
\hline BKV4-3A & $7.39 \mathrm{E}+04$ & 90 & - & - & 9.0 & - & - & (50) & - & $<25$ & - & (500) & - & 88,371 & - & - \\
\hline BKV4-3.2 & $7.39 \mathrm{E}+04$ & 90 & $6.0 \mathrm{E}-05$ & 1.93 & 9.0 & 2.0068 & $5.91 \mathrm{E}-02$ & (65) & $8.18 \mathrm{E}-04$ & 233 & $4.88 \mathrm{E}-03$ & 2,579 & $1.91 \mathrm{E}-02$ & 91,647 & $1.31 \mathrm{E}-02$ & 7.31E-09 \\
\hline BKV4-3.3 & $7.39 \mathrm{E}+04$ & 90 & $5.4 \mathrm{E}-05$ & 2.84 & 9.0 & 2.0064 & $5.91 \mathrm{E}-02$ & (88) & $1.87 \mathrm{E}-03$ & 282 & $5.43 \mathrm{E}-03$ & 2,859 & $1.95 \mathrm{E}-02$ & 91,848 & $1.25 \mathrm{E}-02$ & 7.05E-09 \\
\hline BKV4-3.4 & $7.39 \mathrm{E}+04$ & 90 & $5.2 \mathrm{E}-05$ & 3.69 & 9.0 & 2.0061 & $5.91 \mathrm{E}-02$ & (74) & $1.15 \mathrm{E}-03$ & 227 & $4.12 \mathrm{E}-03$ & 1,914 & $1.13 \mathrm{E}-02$ & 85,324 & 0.00 & 4.07E-09 \\
\hline BKV4-3.5 & $7.39 \mathrm{E}+04$ & 90 & $5.4 \mathrm{E}-05$ & 4.94 & 9.0 & 2.0057 & $5.91 \mathrm{E}-02$ & (88) & $1.92 \mathrm{E}-03$ & 215 & $4.03 \mathrm{E}-03$ & 1,606 & $9.24 \mathrm{E}-03$ & 89,775 & $5.10 \mathrm{E}-03$ & $2.92 \mathrm{E}-09$ \\
\hline BKV4-3.6 & $7.39 \mathrm{E}+04$ & 90 & $5.9 \mathrm{E}-05$ & 6.06 & 9.0 & 2.0052 & $5.91 \mathrm{E}-02$ & (77) & $1.49 \mathrm{E}-03$ & 215 & $4.41 \mathrm{E}-03$ & 1,394 & $8.13 \mathrm{E}-03$ & 92,240 & $1.53 \mathrm{E}-02$ & $2.65 \mathrm{E}-09$ \\
\hline BKV4-3.7 & $7.39 \mathrm{E}+04$ & 90 & $5.6 \mathrm{E}-05$ & 6.70 & 9.0 & 2.0050 & $5.91 \mathrm{E}-02$ & (73) & $1.18 \mathrm{E}-03$ & 213 & $4.10 \mathrm{E}-03$ & 1,281 & $6.69 \mathrm{E}-03$ & 92,532 & $1.55 \mathrm{E}-02$ & $2.20 \mathrm{E}-09$ \\
\hline BKV4-3.16 & $7.39 \mathrm{E}+04$ & 90 & $3.1 \mathrm{E}-05$ & 16.71 & 9.0 & 2.0046 & $5.91 \mathrm{E}-02$ & 192 & $4.06 \mathrm{E}-03$ & 450 & $5.17 \mathrm{E}-03$ & 1560 & $5.07 \mathrm{E}-03$ & 90648 & $4.73 \mathrm{E}-03$ & $4.00 \mathrm{E}-10$ \\
\hline BKV4-3.20 & 7.39E+04 & 90 & $3.7 \mathrm{E}-05$ & 24.72 & 9.0 & 2.0016 & $5.90 \mathrm{E}-02$ & 195 & 4.93E-03 & 401 & $5.44 \mathrm{E}-03$ & 1260 & 4.32E-03 & 85444 & 0.00 & 0.00 \\
\hline BKV4-3.22 & $7.39 \mathrm{E}+04$ & 90 & $3.8 \mathrm{E}-05$ & 29.79 & 9.0 & 2.0002 & $5.90 \mathrm{E}-02$ & 190 & $4.95 \mathrm{E}-03$ & 369 & $5.17 \mathrm{E}-03$ & 1429 & $5.48 \mathrm{E}-03$ & 90987 & $6.72 \mathrm{E}-03$ & $2.13 \mathrm{E}-10$ \\
\hline BKV4-3.23 & $7.39 \mathrm{E}+04$ & 90 & $3.5 \mathrm{E}-05$ & 31.77 & 9.0 & 1.9990 & $5.89 \mathrm{E}-02$ & 196 & $4.66 \mathrm{E}-03$ & 381 & $4.82 \mathrm{E}-03$ & 1321 & 4.36E-03 & 88126 & 0.00 & 0.00 \\
\hline \multicolumn{17}{|l|}{ Exp. \#79 } \\
\hline BKV4-4A & $1.06 \mathrm{E}+05$ & 90 & - & - & 9.0 & - & - & $(50)$ & - & $<25$ & - & $(500)$ & - & 133,518 & - & - \\
\hline BKV4-4.2 & $1.06 \mathrm{E}+05$ & 90 & $3.4 \mathrm{E}-05$ & 1.93 & 9.0 & 2.0039 & $5.90 \mathrm{E}-02$ & (26) & 0.00 & 126 & $1.33 \mathrm{E}-03$ & 2,084 & $8.15 \mathrm{E}-03$ & 134,482 & $2.16 \mathrm{E}-03$ & $3.54 \mathrm{E}-09$ \\
\hline BKV4-4.3 & $1.06 \mathrm{E}+05$ & 90 & $6.8 \mathrm{E}-05$ & 2.84 & 9.0 & 2.0038 & $5.90 \mathrm{E}-02$ & (35) & 0.00 & 156 & $3.51 \mathrm{E}-03$ & 2,529 & $2.13 \mathrm{E}-02$ & 135,128 & 7.34E-03 & 8.89E-09 \\
\hline BKV4-4.4 & $1.06 \mathrm{E}+05$ & 90 & $6.1 \mathrm{E}-05$ & 3.69 & 9.0 & 2.0037 & $5.90 \mathrm{E}-02$ & (21) & 0.00 & 122 & $2.31 \mathrm{E}-03$ & 1,881 & $1.29 \mathrm{E}-02$ & 134,491 & $3.96 \mathrm{E}-03$ & $5.81 \mathrm{E}-09$ \\
\hline BKV4-4.5 & $1.06 \mathrm{E}+05$ & 90 & $5.5 \mathrm{E}-05$ & 4.94 & 9.0 & 2.0036 & $5.90 \mathrm{E}-02$ & (10) & 0.00 & 95 & $1.51 \mathrm{E}-03$ & 1,389 & $7.51 \mathrm{E}-03$ & 136,252 & $1.00 \mathrm{E}-02$ & $3.82 \mathrm{E}-09$ \\
\hline BKV4-4.6 & $1.06 \mathrm{E}+05$ & 90 & $6.1 \mathrm{E}-05$ & 6.06 & 9.0 & 2.0036 & $5.90 \mathrm{E}-02$ & (6) & 0.00 & 84 & $1.40 \mathrm{E}-03$ & 1,092 & $5.55 \mathrm{E}-03$ & 136,539 & $1.23 \mathrm{E}-02$ & $3.20 \mathrm{E}-09$ \\
\hline BKV4-4.7 & $1.06 \mathrm{E}+05$ & 90 & $5.9 \mathrm{E}-05$ & 6.70 & 9.0 & 2.0036 & $5.90 \mathrm{E}-02$ & (2) & 0.00 & 75 & $1.16 \mathrm{E}-03$ & (927) & $3.90 \mathrm{E}-03$ & 137,334 & $1.51 \mathrm{E}-02$ & $2.60 \mathrm{E}-09$ \\
\hline BKV4-4.16 & $1.06 \mathrm{E}+05$ & 90 & $3.1 \mathrm{E}-05$ & 16.71 & 9.0 & 2.0033 & $5.90 \mathrm{E}-02$ & 182 & $3.77 \mathrm{E}-03$ & 376 & $4.26 \mathrm{E}-03$ & 1588 & $5.18 \mathrm{E}-03$ & 134755 & $2.56 \mathrm{E}-03$ & $5.61 \mathrm{E}-10$ \\
\hline BKV4-4.18 & $1.06 \mathrm{E}+05$ & 90 & $3.9 \mathrm{E}-05$ & 20.71 & 9.0 & 2.0022 & $5.90 \mathrm{E}-02$ & 156 & $3.78 \mathrm{E}-03$ & 299 & $4.16 \mathrm{E}-03$ & 1240 & $4.40 \mathrm{E}-03$ & 132446 & 0.00 & $2.51 \mathrm{E}-10$ \\
\hline BKV4-4.20 & $1.06 \mathrm{E}+05$ & 90 & $4.3 \mathrm{E}-05$ & 24.72 & 9.0 & 2.0008 & $5.90 \mathrm{E}-02$ & 140 & $3.59 \mathrm{E}-03$ & 266 & $4.08 \mathrm{E}-03$ & 1170 & $4.46 \mathrm{E}-03$ & 129450 & 0.00 & $3.48 \mathrm{E}-10$ \\
\hline BKV4-4.22 & $1.06 \mathrm{E}+05$ & 90 & $3.4 \mathrm{E}-05$ & 29.79 & 9.0 & 1.9998 & $5.89 \mathrm{E}-02$ & 122 & $2.24 \mathrm{E}-03$ & 219 & $2.55 \mathrm{E}-03$ & 1048 & $2.82 \mathrm{E}-03$ & 131577 & 0.00 & $2.34 \mathrm{E}-10$ \\
\hline BKV4-4.23 & $1.06 \mathrm{E}+05$ & 90 & $3.7 \mathrm{E}-05$ & 31.77 & 9.0 & 1.9990 & $5.89 \mathrm{E}-02$ & 132 & $2.81 \mathrm{E}-03$ & 216 & $2.78 \mathrm{E}-03$ & 1005 & 2.89E-03 & 131385 & 0.00 & $2.98 \mathrm{E}-11$ \\
\hline \multicolumn{17}{|l|}{ Exp. \#80 } \\
\hline
\end{tabular}


Table B1. SPFT Temperature Sweep, Experimental Conditions, and Dissolution Rates. Data in parenthesis are near quantification limit.

\begin{tabular}{|c|c|c|c|c|c|c|c|c|c|c|c|c|c|c|c|c|}
\hline$\underline{\text { Sample ID }}$ & $\begin{array}{l}\text { Influent Si } \\
\underline{\left(\mu g \mathrm{~L}^{-1}\right)}\end{array}$ & $\frac{\mathrm{T}}{\left({ }^{\circ} \mathrm{C}\right)}$ & $\begin{array}{l}\text { Flow Rate } \\
\left(\mathrm{m}^{3} / \mathrm{day}\right) \\
\end{array}$ & $\begin{array}{l}\text { Time } \\
\underline{\text { (days) }}\end{array}$ & $\begin{array}{c}\mathrm{pH} \\
\underline{\left(23^{\circ} \mathrm{C}\right)} \\
\end{array}$ & $\begin{array}{l}\text { Mass } \\
\underline{(\mathrm{g})}\end{array}$ & $\begin{array}{l}\text { Sur. Area } \\
\qquad\left(\mathrm{m}^{2}\right)\end{array}$ & $\begin{array}{c}B \\
\left(\mu g \mathrm{~L}^{-1}\right) \\
\end{array}$ & $\begin{array}{c}\text { B Rate } \\
\left(\mathrm{g} \mathrm{m}^{-2} \mathrm{~d}^{-1}\right) \\
\end{array}$ & $\begin{array}{c}\mathrm{Al} \\
\left.(\mu \mathrm{g} \mathrm{L})^{-1}\right) \\
\end{array}$ & $\begin{array}{l}\text { Al Rate } \\
\left(\mathrm{g} \mathrm{m}^{-2} \mathrm{~d}^{-1}\right) \\
\end{array}$ & $\begin{array}{c}\mathrm{Na} \\
\left(\mu g \mathrm{~L}^{-1}\right) \\
\end{array}$ & $\begin{array}{l}\text { Na Rate } \\
\underline{\left(\mathrm{g} \mathrm{m}^{-2} \mathrm{~d}^{-1}\right)} \\
\end{array}$ & $\begin{array}{c}\mathrm{Si} \\
\left(\mu g \mathrm{~L}^{-1}\right) \\
\end{array}$ & $\begin{array}{l}\text { Si Rate } \\
\left(\mathrm{g} \mathrm{m}^{-2} \mathrm{~d}^{-1}\right) \\
\end{array}$ & $\begin{array}{c}\text { IEX Rate } \\
\underline{\left(\mathrm{mol} \mathrm{m}^{-2} \mathrm{~s}^{-1}\right)} \\
\end{array}$ \\
\hline BKV4-5.3 & $1.22 \mathrm{E}+05$ & 90 & $5.7 \mathrm{E}-05$ & 2.84 & 9.0 & 3.0048 & $8.85 \mathrm{E}-02$ & (8) & 0.00 & 94 & $1.02 \mathrm{E}-03$ & 2,176 & $9.72 \mathrm{E}-03$ & 163,403 & 0.00 & 4.46E-09 \\
\hline BKV4-5.5 & $1.22 \mathrm{E}+05$ & 90 & $5.2 \mathrm{E}-05$ & 4.94 & 9.0 & 3.0047 & $8.85 \mathrm{E}-02$ & (5) & 0.00 & 71 & $6.24 \mathrm{E}-04$ & 2,186 & $9.03 \mathrm{E}-03$ & 170,993 & 0.00 & $4.18 \mathrm{E}-09$ \\
\hline BKV4-5.6 & $1.22 \mathrm{E}+05$ & 90 & $6.1 \mathrm{E}-05$ & 6.06 & 9.0 & 3.0047 & $8.85 \mathrm{E}-02$ & ND & - & 88 & $9.96 \mathrm{E}-04$ & 1,925 & $8.85 \mathrm{E}-03$ & 174,321 & $1.29 \mathrm{E}-03$ & 0.00 \\
\hline BKV4-5.7 & $1.22 \mathrm{E}+05$ & 90 & $4.8 \mathrm{E}-05$ & 6.70 & 9.0 & 3.0047 & $8.85 \mathrm{E}-02$ & ND & - & 74 & $6.17 \mathrm{E}-04$ & 1,703 & $5.93 \mathrm{E}-03$ & 174,022 & $3.82 \mathrm{E}-04$ & 0.00 \\
\hline BKV4-5.16 & $1.22 \mathrm{E}+05$ & 90 & $3.7 \mathrm{E}-05$ & 16.71 & 9.0 & 3.0046 & $8.85 \mathrm{E}-02$ & 115 & $1.45 \mathrm{E}-03$ & 110 & $8.16 \mathrm{E}-04$ & 1544 & $3.91 \mathrm{E}-03$ & 175772 & $3.14 \mathrm{E}-03$ & $9.83 \mathrm{E}-10$ \\
\hline BKV4-5.20 & $1.22 \mathrm{E}+05$ & 90 & $3.7 \mathrm{E}-05$ & 24.72 & 9.0 & 3.0033 & $8.85 \mathrm{E}-02$ & 80 & $6.85 \mathrm{E}-04$ & 54 & $2.84 \mathrm{E}-04$ & 810 & $1.18 \mathrm{E}-03$ & 172590 & 0.00 & $1.96 \mathrm{E}-10$ \\
\hline BKV4-5.22 & $1.22 \mathrm{E}+05$ & 90 & $3.3 \mathrm{E}-05$ & 29.79 & 9.0 & 3.0027 & $8.85 \mathrm{E}-02$ & 75 & $5.04 \mathrm{E}-04$ & 42 & $1.51 \mathrm{E}-04$ & 716 & $7.36 \mathrm{E}-04$ & 174776 & $1.38 \mathrm{E}-03$ & $9.26 \mathrm{E}-11$ \\
\hline $\begin{array}{c}\text { BKV4-5.23 } \\
\text { Exp. \#81 }\end{array}$ & $1.22 \mathrm{E}+05$ & 90 & $3.8 \mathrm{E}-05$ & 31.77 & 9.0 & 3.0023 & $8.85 \mathrm{E}-02$ & 77 & $6.37 \mathrm{E}-04$ & 60 & $3.54 \mathrm{E}-04$ & 763 & $1.03 \mathrm{E}-03$ & 158266 & 0.00 & $1.58 \mathrm{E}-10$ \\
\hline BKV4-6A & $1.39 \mathrm{E}+05$ & 90 & - & - & 9.0 & - & - & $(0)$ & - & $<25$ & - & $(500)$ & - & 204,757 & - & - \\
\hline BKV4-6.2 & $1.39 \mathrm{E}+05$ & 90 & $5.6 \mathrm{E}-05$ & 1.93 & 9.0 & 3.0079 & $8.86 \mathrm{E}-02$ & (22) & $7.54 \mathrm{E}-04$ & 65 & $5.90 \mathrm{E}-04$ & 3,010 & $1.44 \mathrm{E}-02$ & 203,798 & 0.00 & $5.47 \mathrm{E}-09$ \\
\hline BKV4-6.3 & $1.39 \mathrm{E}+05$ & 90 & $5.1 \mathrm{E}-05$ & 2.84 & 9.0 & 3.0079 & $8.86 \mathrm{E}-02$ & (9) & $2.78 \mathrm{E}-04$ & 70 & 5.99E-04 & 2,892 & $1.26 \mathrm{E}-02$ & 178,641 & 0.00 & $4.91 \mathrm{E}-09$ \\
\hline BKV4-6.4 & $1.39 \mathrm{E}+05$ & 90 & $5.8 \mathrm{E}-05$ & 3.69 & 9.0 & 3.0079 & $8.86 \mathrm{E}-02$ & ND & 0.00 & 68 & $6.53 \mathrm{E}-04$ & 2,137 & $9.66 \mathrm{E}-03$ & 180,783 & 0.00 & $3.86 \mathrm{E}-09$ \\
\hline BKV4-6.6 & $1.39 \mathrm{E}+05$ & 90 & $5.0 \mathrm{E}-05$ & 6.06 & 9.0 & 3.0079 & $8.86 \mathrm{E}-02$ & ND & 0.00 & 50 & $3.34 \mathrm{E}-04$ & 1,948 & $7.45 \mathrm{E}-03$ & 195,506 & 0.00 & $2.97 \mathrm{E}-09$ \\
\hline BKV4-6.7 & $1.39 \mathrm{E}+05$ & 90 & $5.7 \mathrm{E}-05$ & 6.70 & 9.0 & 3.0079 & $8.86 \mathrm{E}-02$ & ND & 0.00 & 39 & $2.10 \mathrm{E}-04$ & 1,742 & $7.25 \mathrm{E}-03$ & 200,002 & 0.00 & $2.90 \mathrm{E}-09$ \\
\hline BKV4-6.16 & $1.39 \mathrm{E}+05$ & 90 & $3.5 \mathrm{E}-05$ & 16.71 & 9.0 & 3.0079 & 8.86E-02 & (14) & $2.99 \mathrm{E}-04$ & 77 & $4.76 \mathrm{E}-04$ & 1174 & $2.42 \mathrm{E}-03$ & 168282 & 0.00 & $8.49 \mathrm{E}-10$ \\
\hline BKV4-6.18 & $1.39 \mathrm{E}+05$ & 90 & $3.5 \mathrm{E}-05$ & 20.71 & 9.0 & 3.0079 & $8.86 \mathrm{E}-02$ & ND & - & 23 & 0.00 & 726 & $8.10 \mathrm{E}-04$ & 182509 & 0.00 & $3.23 \mathrm{E}-10$ \\
\hline BKV4-6.20 & $1.39 \mathrm{E}+05$ & 90 & $3.7 \mathrm{E}-05$ & 24.72 & 9.0 & 3.0079 & $8.86 \mathrm{E}-02$ & ND & - & 9 & 0.00 & 706 & $7.89 \mathrm{E}-04$ & 142925 & 0.00 & $3.15 \mathrm{E}-10$ \\
\hline BKV4-6.22 & $1.39 \mathrm{E}+05$ & 90 & $3.6 \mathrm{E}-05$ & 29.79 & 9.0 & 3.0079 & 8.86E-02 & ND & - & 8 & 0.00 & 602 & $3.70 \mathrm{E}-04$ & 142393 & 0.00 & $1.48 \mathrm{E}-10$ \\
\hline BKV4-6.23 & $1.39 \mathrm{E}+05$ & 90 & $3.7 \mathrm{E}-05$ & 31.77 & 9.0 & 3.0079 & $8.86 \mathrm{E}-02$ & ND & - & 14 & 0.00 & 684 & $7.03 \mathrm{E}-04$ & 164910 & 0.00 & $2.81 \mathrm{E}-10$ \\
\hline
\end{tabular}

\section{Foam}

Exp. \#82

$\begin{array}{ll}\text { BKV5-1A } & 8.79 \mathrm{E}+02 \\ \text { BKV5-1.2 } & 8.79 \mathrm{E}+02 \\ \text { BKV5-1.3 } & 8.79 \mathrm{E}+02 \\ \text { BKV5-1.4 } & 8.79 \mathrm{E}+02 \\ \text { BKV5-1.5 } & 8.79 \mathrm{E}+02 \\ \text { BKV5-1.6 } & 8.79 \mathrm{E}+02 \\ \text { BKV5-1.7 } & 8.79 \mathrm{E}+02\end{array}$

Exp. \#83

$\begin{array}{lccccc}90 & - & - & 9.0 & - & - \\ 90 & 5.5 \mathrm{E}-05 & 1.93 & 9.0 & 1.0054 & 2.96 \mathrm{E}-02 \\ 90 & 5.7 \mathrm{E}-05 & 2.84 & 9.0 & 1.0027 & 2.96 \mathrm{E}-02 \\ 90 & 5.1 \mathrm{E}-05 & 3.69 & 9.0 & 1.0003 & 2.95 \mathrm{E}-02 \\ 90 & 5.6 \mathrm{E}-05 & 4.94 & 9.0 & 0.9971 & 2.94 \mathrm{E}-02 \\ 90 & 5.6 \mathrm{E}-05 & 6.06 & 9.0 & 0.9938 & 2.93 \mathrm{E}-02 \\ 90 & 5.1 \mathrm{E}-05 & 6.70 & 9.0 & 0.9916 & 2.92 \mathrm{E}-02\end{array}$

$<25$
492
696
653
658
648
633

-
$4.57 \mathrm{E}-02$
$6.74 \mathrm{E}-02$
$5.71 \mathrm{E}-02$
$6.31 \mathrm{E}-02$
$6.25 \mathrm{E}-02$
$5.60 \mathrm{E}-02$

$1,440 \quad 5.36 \mathrm{E}-02$

$1,977 \quad 7.58 \mathrm{E}-02$

$1,852 \quad 6.43 \mathrm{E}-02$

$1,894 \quad 7.20 \mathrm{E}-02$

$1,831 \quad 7.01 \mathrm{E}-02$

895

3.09E-02 3,127

$3,127 \quad 3.79 \mathrm{E}-02$

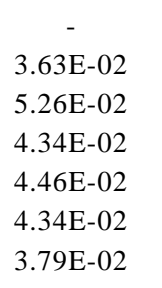

$<1000$

7,004 5.04E-02

$7.37 \mathrm{E}-02$

0.00

9,570

8,930

9,066

$6.18 \mathrm{E}-02$

$6.88 \mathrm{E}-02$

$6.67 \mathrm{E}-02$

0.00

0.00

0.00

$8,232 \quad 5.70 \mathrm{E}-02$ 
Table B1. SPFT Temperature Sweep, Experimental Conditions, and Dissolution Rates. Data in parenthesis are near quantification limit.

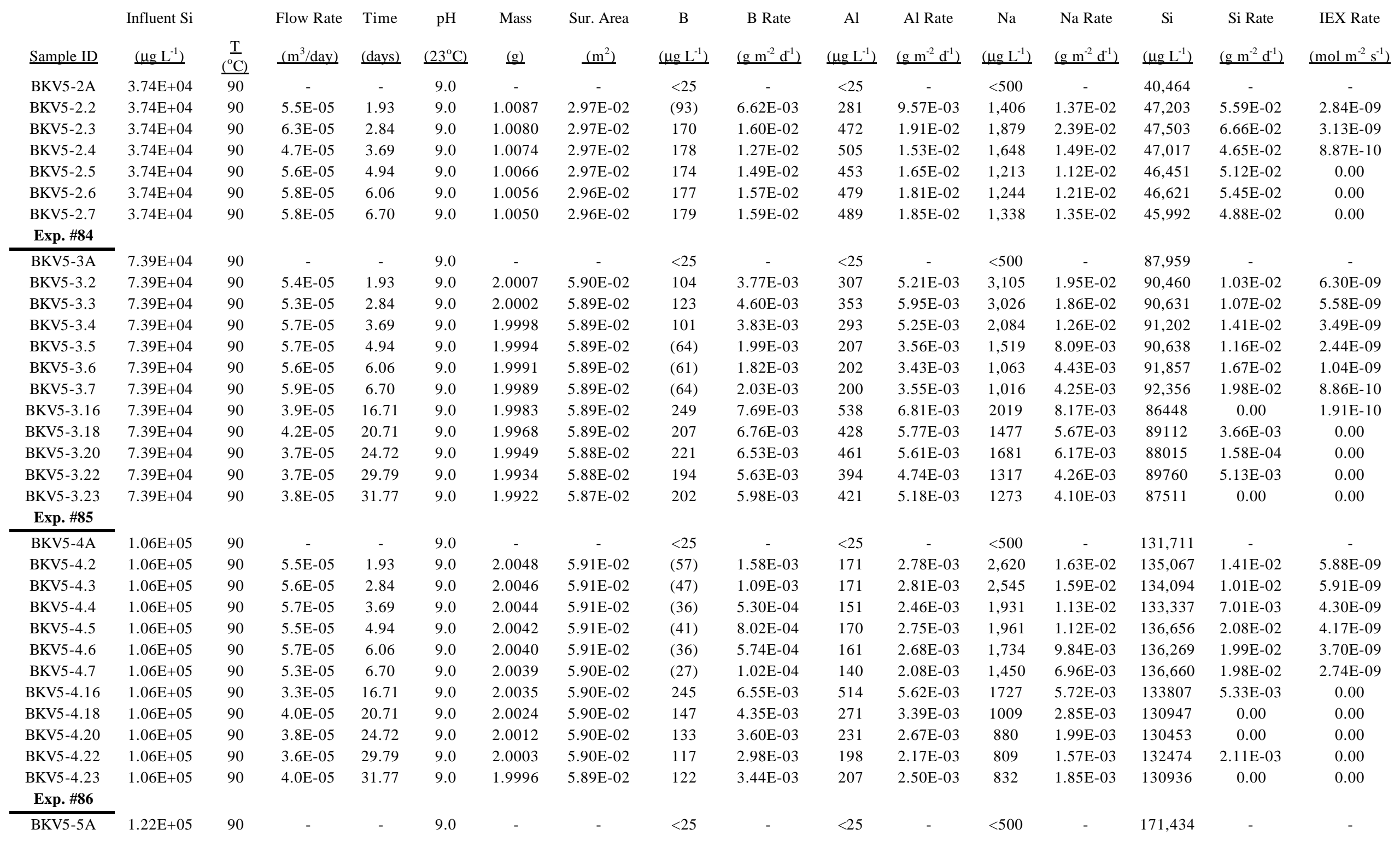


Table B1. SPFT Temperature Sweep, Experimental Conditions, and Dissolution Rates. Data in parenthesis are near quantification limit.

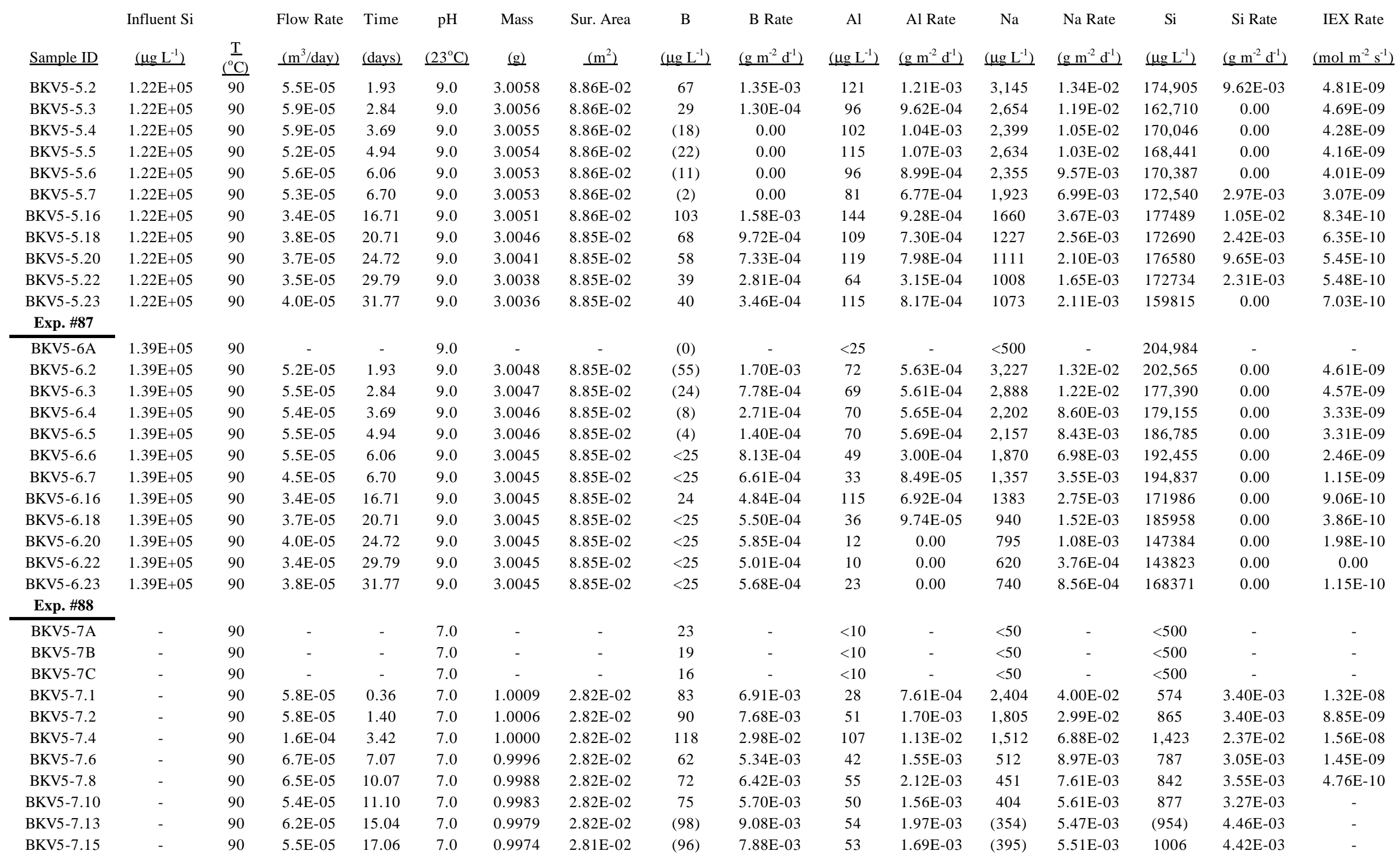


Table B1. SPFT Temperature Sweep, Experimental Conditions, and Dissolution Rates. Data in parenthesis are near quantification limit.

\begin{tabular}{|c|c|c|c|c|c|c|c|c|c|c|c|c|c|c|c|c|}
\hline$\underline{\text { Sample ID }}$ & $\begin{array}{l}\text { Influent Si } \\
\underline{\left(\mu \mathrm{g} \mathrm{L}^{-1}\right)}\end{array}$ & $\frac{\mathrm{T}}{\left({ }^{\circ} \mathrm{C}\right)}$ & $\begin{array}{l}\text { Flow Rate } \\
\underline{\left(\mathrm{m}^{3} / \mathrm{day}\right)}\end{array}$ & $\begin{array}{l}\text { Time } \\
\underline{\text { (days) }}\end{array}$ & $\begin{array}{c}\mathrm{pH} \\
\left(23^{\circ} \mathrm{C}\right) \\
\end{array}$ & $\begin{array}{l}\text { Mass } \\
\underline{(\mathrm{g})}\end{array}$ & $\begin{array}{l}\text { Sur. Area } \\
\qquad \underline{\left(\mathrm{m}^{2}\right)}\end{array}$ & $\begin{array}{c}B \\
\left(\mu \mathrm{g} \mathrm{L}^{-1}\right) \\
\end{array}$ & $\begin{array}{c}\text { B Rate } \\
\left(\mathrm{g} \mathrm{m}^{-2} \mathrm{~d}^{-1}\right) \\
\end{array}$ & $\begin{array}{c}\mathrm{Al} \\
\left.(\mu \mathrm{g} \mathrm{L})^{-1}\right) \\
\end{array}$ & $\begin{array}{l}\text { Al Rate } \\
\left(\mathrm{g} \mathrm{m}^{-2} \mathrm{~d}^{-1}\right) \\
\end{array}$ & $\begin{array}{c}\mathrm{Na} \\
\underline{\left(\mu g \mathrm{~L}^{-1}\right)} \\
\end{array}$ & $\begin{array}{l}\text { Na Rate } \\
\underline{\left(\mathrm{g} \mathrm{m}^{-2} \mathrm{~d}^{-1}\right)} \\
\end{array}$ & $\begin{array}{c}\mathrm{Si} \\
\left(\mu \mathrm{g} \mathrm{L}^{-1}\right) \\
\end{array}$ & $\begin{array}{l}\text { Si Rate } \\
\left(\mathrm{g} \mathrm{m}^{-2} \mathrm{~d}^{-1}\right) \\
\end{array}$ & $\begin{array}{c}\text { IEX Rate } \\
\underline{\left(\mathrm{mol} \mathrm{m}^{-2} \mathrm{~s}^{-1}\right)}\end{array}$ \\
\hline Exp. \#89 & & & & & & & & & & & & & & & & \\
\hline BKV5-8B & - & 90 & - & - & 8.0 & - & - & $<100$ & - & $<10$ & - & 64 & - & $<500$ & - & - \\
\hline BKV5-8C & - & 90 & - & - & 8.0 & - & - & $<100$ & - & $<10$ & - & 203 & - & $<500$ & - & - \\
\hline BKV5-8.1 & - & 90 & $5.9 \mathrm{E}-05$ & 0.36 & 8.0 & 1.0009 & $2.82 \mathrm{E}-02$ & 74 & 0.00 & 179 & $7.16 \mathrm{E}-03$ & 1,276 & $1.98 \mathrm{E}-02$ & 885 & $3.61 \mathrm{E}-03$ & 9.03E-09 \\
\hline BKV5-8.2 & - & 90 & 5.9E-05 & 1.40 & 8.0 & 1.0003 & 2.82E-02 & 179 & $8.63 \mathrm{E}-03$ & 454 & $1.88 \mathrm{E}-02$ & 1,816 & $2.90 \mathrm{E}-02$ & 2,377 & $1.76 \mathrm{E}-02$ & $8.15 \mathrm{E}-09$ \\
\hline BKV5-8.4 & - & 90 & $1.2 \mathrm{E}-04$ & 3.42 & 8.0 & 0.9994 & $2.82 \mathrm{E}-02$ & 233 & $3.06 \mathrm{E}-02$ & 639 & $5.60 \mathrm{E}-02$ & 1,331 & $4.36 \mathrm{E}-02$ & 2,940 & $4.81 \mathrm{E}-02$ & 5.19E-09 \\
\hline BKV5-8.6 & - & 90 & $6.7 \mathrm{E}-05$ & 7.07 & 8.0 & 0.9982 & $2.82 \mathrm{E}-02$ & 243 & $1.79 \mathrm{E}-02$ & 648 & $3.08 \mathrm{E}-02$ & 1,265 & $2.24 \mathrm{E}-02$ & 3,051 & $2.73 \mathrm{E}-02$ & $1.80 \mathrm{E}-09$ \\
\hline BKV5-8.8 & - & 90 & $6.0 \mathrm{E}-05$ & 10.07 & 8.0 & 0.9947 & $2.81 \mathrm{E}-02$ & 360 & 2.92E-02 & 988 & $4.25 \mathrm{E}-02$ & 1,616 & $2.63 \mathrm{E}-02$ & 4,709 & $4.05 \mathrm{E}-02$ & 0.00 \\
\hline BKV5-8.10 & - & 90 & $6.3 \mathrm{E}-05$ & 11.10 & 8.0 & 0.9919 & $2.80 \mathrm{E}-02$ & 344 & $2.86 \mathrm{E}-02$ & 959 & $4.31 \mathrm{E}-02$ & 1,679 & $2.86 \mathrm{E}-02$ & 4,372 & $3.90 \mathrm{E}-02$ & $1.78 \mathrm{E}-11$ \\
\hline BKV5-8.13 & - & 90 & $6.3 \mathrm{E}-05$ & 15.04 & 8.0 & 0.9903 & $2.80 \mathrm{E}-02$ & 348 & $2.92 \mathrm{E}-02$ & 927 & $4.18 \mathrm{E}-02$ & 1527 & $2.60 \mathrm{E}-02$ & 4661 & $4.21 \mathrm{E}-02$ & 0.00 \\
\hline $\begin{array}{c}\text { BKV5-8.15 } \\
\text { Exp. \#90 }\end{array}$ & - & 90 & $5.6 \mathrm{E}-05$ & 17.06 & 8.0 & 0.9885 & $2.79 \mathrm{E}-02$ & 343 & $2.54 \mathrm{E}-02$ & 903 & $3.61 \mathrm{E}-02$ & 1632 & $2.47 \mathrm{E}-02$ & 4691 & $3.75 \mathrm{E}-02$ & 0.00 \\
\hline BKV5-9A & - & 90 & - & - & 9.0 & - & - & $<100$ & - & $<10$ & - & $<50$ & - & $<500$ & - & - \\
\hline BKV5-9B & - & 90 & - & - & 9.0 & - & - & $<100$ & - & $<10$ & - & $<50$ & - & $<500$ & - & - \\
\hline BKV5-9.1 & - & 90 & $6.2 \mathrm{E}-05$ & 0.36 & 9.0 & 0.5008 & $1.41 \mathrm{E}-02$ & 146 & $1.05 \mathrm{E}-02$ & 448 & $3.89 \mathrm{E}-02$ & 922 & $3.14 \mathrm{E}-02$ & 1,870 & $2.70 \mathrm{E}-02$ & 8.36E-09 \\
\hline BKV5-9.2 & - & 90 & $6.2 \mathrm{E}-05$ & 1.40 & 9.0 & 0.4993 & $1.41 \mathrm{E}-02$ & 423 & 7.44E-02 & 1,219 & $1.08 \mathrm{E}-01$ & 2,138 & $7.53 \mathrm{E}-02$ & 5,281 & $9.43 \mathrm{E}-02$ & $3.60 \mathrm{E}-10$ \\
\hline BKV5-9.4 & - & 90 & $1.3 \mathrm{E}-04$ & 3.42 & 9.0 & 0.4974 & $1.41 \mathrm{E}-02$ & 442 & $1.66 \mathrm{E}-01$ & 1,289 & $2.40 \mathrm{E}-01$ & 2,145 & $1.59 \mathrm{E}-01$ & 5,572 & $2.11 \mathrm{E}-01$ & 0.00 \\
\hline BKV5-9.6 & - & 90 & $6.9 \mathrm{E}-05$ & 7.07 & 9.0 & 0.4951 & $1.40 \mathrm{E}-02$ & 459 & $9.30 \mathrm{E}-02$ & 1,333 & $1.32 \mathrm{E}-01$ & 2,219 & $8.80 \mathrm{E}-02$ & 5,882 & $1.19 \mathrm{E}-01$ & 0.00 \\
\hline BKV5-9.8 & - & 90 & $6.5 \mathrm{E}-05$ & 10.07 & 9.0 & 0.4886 & $1.38 \mathrm{E}-02$ & 602 & $1.24 \mathrm{E}-01$ & 1,844 & $1.75 \mathrm{E}-01$ & 3,054 & $1.16 \mathrm{E}-01$ & 7,411 & $1.46 \mathrm{E}-01$ & 0.00 \\
\hline BKV5-9.10 & - & 90 & $5.7 \mathrm{E}-05$ & 11.10 & 9.0 & 0.4818 & $1.37 \mathrm{E}-02$ & 1,214 & $2.44 \mathrm{E}-01$ & 3,590 & $3.03 \mathrm{E}-01$ & 5,859 & $1.99 \mathrm{E}-01$ & 14,100 & $2.55 \mathrm{E}-01$ & 0.00 \\
\hline BKV5-9.13 & - & 90 & $6.0 \mathrm{E}-05$ & 15.04 & 9.0 & 0.4781 & $1.35 \mathrm{E}-02$ & 607 & $1.19 \mathrm{E}-01$ & 1,671 & $1.51 \mathrm{E}-01$ & 2834 & $1.02 \mathrm{E}-01$ & 7896 & $1.49 \mathrm{E}-01$ & 0.00 \\
\hline $\begin{array}{c}\text { BKV5-9.15 } \\
\text { Exp. \#91 }\end{array}$ & - & 90 & $5.6 \mathrm{E}-05$ & 17.06 & 9.0 & 0.4751 & $1.34 \mathrm{E}-02$ & 608 & $1.11 \mathrm{E}-01$ & 1,687 & $1.41 \mathrm{E}-01$ & 3009 & $1.01 \mathrm{E}-01$ & 7921 & $1.38 \mathrm{E}-01$ & 0.00 \\
\hline BKV5-10A & - & 90 & - & - & 10.0 & - & - & $<100$ & - & 12 & - & 51 & - & 501 & - & - \\
\hline BKV5-10B & - & 90 & - & - & 10.0 & - & - & $<100$ & - & 23 & - & $<50$ & - & $<500$ & - & - \\
\hline BKV5-10C & - & 90 & - & - & 10.0 & - & - & $<100$ & - & 22 & - & $<50$ & - & $<500$ & - & - \\
\hline BKV5-10.1 & - & 90 & $6.4 \mathrm{E}-05$ & 0.36 & 10.0 & 0.5048 & $1.42 \mathrm{E}-02$ & 187 & $2.05 \mathrm{E}-02$ & 663 & $5.84 \mathrm{E}-02$ & 1,100 & $3.86 \mathrm{E}-02$ & 2,378 & $3.78 \mathrm{E}-02$ & $7.25 \mathrm{E}-09$ \\
\hline BKV5-10.2 & - & 90 & $6.4 \mathrm{E}-05$ & 1.40 & 10.0 & 0.5020 & $1.42 \mathrm{E}-02$ & 766 & $1.57 \mathrm{E}-01$ & 2,404 & $2.17 \mathrm{E}-01$ & 4,062 & $1.48 \mathrm{E}-01$ & 9,292 & $1.77 \mathrm{E}-01$ & 0.00 \\
\hline BKV5-10.4 & - & 90 & $1.3 \mathrm{E}-04$ & 3.42 & 10.0 & 0.4981 & $1.41 \mathrm{E}-02$ & 927 & $3.97 \mathrm{E}-01$ & 2,753 & $5.07 \mathrm{E}-01$ & 4,448 & $3.31 \mathrm{E}-01$ & 10,945 & 4.29E-01 & 0.00 \\
\hline BKV5-10.6 & - & 90 & $6.9 \mathrm{E}-05$ & 7.07 & 10.0 & 0.4933 & $1.40 \mathrm{E}-02$ & 963 & $2.22 \mathrm{E}-01$ & 2,778 & $2.75 \mathrm{E}-01$ & 4,798 & $1.92 \mathrm{E}-01$ & 11,387 & $2.40 \mathrm{E}-01$ & 0.00 \\
\hline
\end{tabular}


Table B1. SPFT Temperature Sweep, Experimental Conditions, and Dissolution Rates. Data in parenthesis are near quantification limit.

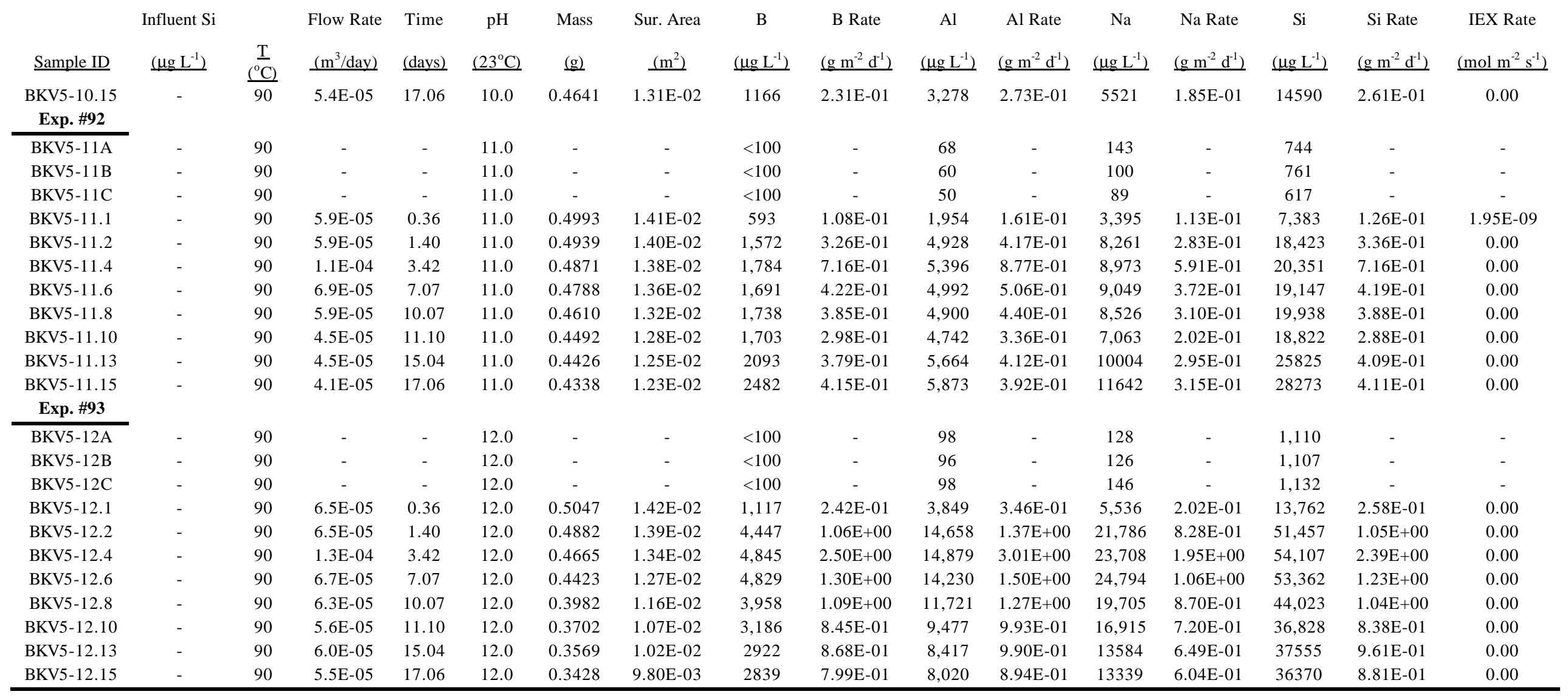




\subsection{Appendix C - Steam Reformer SPFT Test Data}

Table C1. SPFT Test Temperature Sweep, Experimental Conditions, Dissolution Rate for SR Product Steam Reformation SPFT Test

\section{Fluidized Bed-Steam Reformer Material}

\begin{tabular}{|c|c|c|c|c|c|c|c|c|c|c|c|c|c|}
\hline Sample ID & $\begin{array}{c}\text { Dura- } \\
\text { tion } \\
\text { (days) }\end{array}$ & $\begin{array}{c}\mathrm{pH} \\
\left(23^{\circ} \mathrm{C}\right) \\
\end{array}$ & $\begin{array}{c}\text { Flow Rate } \\
\left(\mathrm{m}^{3} / \text { day }\right)\end{array}$ & $\begin{array}{c}\mathrm{Al} \\
\left(\mu \mathrm{g} \mathrm{L}^{-1}\right) \\
\end{array}$ & $\begin{array}{l}\text { Al Rate } \\
\left(\mathrm{g} \mathrm{m}^{-2} \mathrm{~d}^{-1}\right)\end{array}$ & $\begin{array}{c}\mathrm{Si} \\
\left(\mathrm{mg} \mathrm{L}^{-1}\right) \\
\end{array}$ & $\begin{array}{c}\text { Si Rate } \\
\left(\mathrm{g} \mathrm{m}^{-2} \mathrm{~d}^{-1}\right)\end{array}$ & $\begin{array}{c}\mathrm{Na} \\
\left(\mathrm{mg} \mathrm{L}^{-1}\right) \\
\end{array}$ & $\begin{array}{l}\text { Na Rate } \\
\left(\mathrm{g} \mathrm{m}^{-2} \mathrm{~d}^{-1}\right)\end{array}$ & $\begin{array}{c}\mathrm{S} \\
\left(\mu \mathrm{g} \mathrm{L} \mathrm{L}^{-1}\right) \\
\end{array}$ & $\begin{array}{c}\text { S Rate } \\
\left(\mathrm{g} \mathrm{m}^{-2} \mathrm{~d}^{-1}\right) \\
\end{array}$ & $\begin{array}{c}\mathrm{Re} \\
\left(\mu \mathrm{g} \mathrm{L}^{-1}\right) \\
\end{array}$ & $\begin{array}{l}\text { Re Rate } \\
\left(\mathrm{g} \mathrm{m}^{-2} \mathrm{~d}^{-1}\right)\end{array}$ \\
\hline \multicolumn{14}{|l|}{ Cell SCT2-1 } \\
\hline SCT2-1A & - & - & - & 7.9 & - & 0.02 & - & 0.03 & - & 110 & - & 0.012 & - \\
\hline SCT2-1B & - & - & - & 8.6 & - & 0.02 & - & 0.04 & - & 97 & - & 0.012 & - \\
\hline SCT2-1C & - & - & - & 13.3 & - & 0.03 & - & 0.05 & - & 103 & - & 0.012 & - \\
\hline SCT2-1.1 & 1 & 7.465 & $5.80 \mathrm{E}-05$ & 1122 & $3.17 \mathrm{E}-04$ & 15 & $4.20 \mathrm{E}-03$ & 157 & $4.84 \mathrm{E}-02$ & 1145 & $1.36 \mathrm{E}-02$ & 3.14 & $2.68 \mathrm{E}-02$ \\
\hline SCT2-1.2 & 1.84 & 7.343 & $3.80 \mathrm{E}-05$ & 552 & $1.03 \mathrm{E}-04$ & 13 & $2.46 \mathrm{E}-03$ & 94 & $1.91 \mathrm{E}-02$ & 2247 & $1.85 \mathrm{E}-02$ & 4.55 & $2.58 \mathrm{E}-02$ \\
\hline SCT2-1.3 & 3.11 & 7.249 & $6.20 \mathrm{E}-05$ & 529 & $1.58 \mathrm{E}-04$ & 8.9 & $2.61 \mathrm{E}-03$ & 58 & $1.90 \mathrm{E}-02$ & 1521 & $1.97 \mathrm{E}-02$ & 2.67 & $2.43 \mathrm{E}-02$ \\
\hline SCT2-1.6 & 10.29 & 7.111 & $5.50 \mathrm{E}-05$ & 262 & $6.80 \mathrm{E}-05$ & 7.1 & $1.86 \mathrm{E}-03$ & 21 & $6.03 \mathrm{E}-03$ & 1241 & $1.40 \mathrm{E}-02$ & 2.2 & $1.77 \mathrm{E}-02$ \\
\hline SCT2-1.11 & 13.02 & 7.248 & 7.30E-05 & 181 & $6.12 \mathrm{E}-05$ & 7.2 & $2.49 \mathrm{E}-03$ & 15 & $5.92 \mathrm{E}-03$ & 1002 & $1.47 \mathrm{E}-02$ & 1.82 & $1.94 \mathrm{E}-02$ \\
\hline SCT2-1.14 & 16.07 & 7.084 & $5.70 \mathrm{E}-05$ & 199 & $5.28 \mathrm{E}-05$ & 10 & $2.76 \mathrm{E}-03$ & 20 & $6.12 \mathrm{E}-03$ & 1081 & $1.25 \mathrm{E}-02$ & 2.01 & $1.68 \mathrm{E}-02$ \\
\hline SCT2-1.17 & 19.13 & 7.064 & 4.10E-05 & 186 & $3.58 \mathrm{E}-05$ & 10 & $1.98 \mathrm{E}-03$ & 18 & $3.97 \mathrm{E}-03$ & 836 & $6.79 \mathrm{E}-03$ & 1.41 & $8.52 \mathrm{E}-03$ \\
\hline SCT2-1.20 & 20.12 & 7.039 & $6.80 \mathrm{E}-05$ & 153 & $4.77 \mathrm{E}-05$ & 8.8 & $2.85 \mathrm{E}-03$ & 14 & $4.88 \mathrm{E}-03$ & 515 & $6.27 \mathrm{E}-03$ & 0.79 & $7.81 \mathrm{E}-03$ \\
\hline SCT2-1.21 & 21.09 & 7.027 & $3.60 \mathrm{E}-05$ & 161 & 2.67E-05 & 10 & $1.72 \mathrm{E}-03$ & 16 & $3.10 \mathrm{E}-03$ & 572 & $3.79 \mathrm{E}-03$ & 0.91 & $4.78 \mathrm{E}-03$ \\
\hline SCT2-1.22 & 22.05 & 6.989 & $7.20 \mathrm{E}-05$ & 146 & $4.82 \mathrm{E}-05$ & 7.7 & $2.64 \mathrm{E}-03$ & 12 & $4.45 \mathrm{E}-03$ & 424 & $5.19 \mathrm{E}-03$ & 0.595 & $6.20 \mathrm{E}-03$ \\
\hline SCT2-1.23 & 23 & 7.051 & $5.20 \mathrm{E}-05$ & 154 & $3.66 \mathrm{E}-05$ & 8.4 & $2.06 \mathrm{E}-03$ & 12 & $3.28 \mathrm{E}-03$ & 365 & $3.03 \mathrm{E}-03$ & 0.52 & $3.88 \mathrm{E}-03$ \\
\hline \multicolumn{14}{|l|}{ Cell SCT2-2 } \\
\hline SCT2-2A & - & - & - & 13 & - & 0.07 & - & 0.05 & - & 106 & - & 0.012 & - \\
\hline SCT2-2B & - & - & - & 7.3 & - & 0.07 & - & 0.04 & - & 102 & - & 0.012 & - \\
\hline SCT2-2C & - & - & - & 7.8 & - & 0.07 & - & 0.06 & - & 101 & - & 0.012 & - \\
\hline SCT2-2.1 & 1 & 8.315 & $7.20 \mathrm{E}-05$ & 7090 & $2.50 \mathrm{E}-03$ & 13 & $4.43 \mathrm{E}-03$ & 107 & $4.08 \mathrm{E}-02$ & 653 & $8.88 \mathrm{E}-03$ & 1.63 & $1.72 \mathrm{E}-02$ \\
\hline SCT2-2.2 & 1.84 & 8.263 & $4.40 \mathrm{E}-05$ & 5311 & $1.14 \mathrm{E}-03$ & 10 & $2.14 \mathrm{E}-03$ & 56 & $1.31 \mathrm{E}-02$ & 256 & $1.50 \mathrm{E}-03$ & 0.399 & $2.50 \mathrm{E}-03$ \\
\hline SCT2-2.3 & 3.11 & 8.161 & $7.10 \mathrm{E}-05$ & 4972 & $1.72 \mathrm{E}-03$ & 9.3 & $3.11 \mathrm{E}-03$ & 36 & $1.34 \mathrm{E}-02$ & 514 & $6.50 \mathrm{E}-03$ & 1.24 & $1.28 \mathrm{E}-02$ \\
\hline SCT2-2.6 & 10.29 & 8.189 & $7.30 \mathrm{E}-05$ & 4208 & $1.51 \mathrm{E}-03$ & 7.6 & $2.63 \mathrm{E}-03$ & 15 & $5.99 \mathrm{E}-03$ & 1088 & $1.62 \mathrm{E}-02$ & 2.03 & $2.19 \mathrm{E}-02$ \\
\hline SCT2-2.11 & 13.02 & 8.323 & $5.30 \mathrm{E}-05$ & 3936 & $1.03 \mathrm{E}-03$ & 7.1 & $1.79 \mathrm{E}-03$ & 15 & $4.15 \mathrm{E}-03$ & 1126 & $1.22 \mathrm{E}-02$ & 2.11 & $1.65 \mathrm{E}-02$ \\
\hline SCT2-2.14 & 16.07 & 8.146 & $7.80 \mathrm{E}-05$ & 4025 & $1.54 \mathrm{E}-03$ & 7.2 & $2.66 \mathrm{E}-03$ & 13 & $5.30 \mathrm{E}-03$ & 940 & $1.47 \mathrm{E}-02$ & 1.43 & $1.64 \mathrm{E}-02$ \\
\hline SCT2-2.17 & 19.13 & 8.098 & $4.30 \mathrm{E}-05$ & 3354 & 7.07E-04 & 5.7 & $1.15 \mathrm{E}-03$ & 9.8 & $2.22 \mathrm{E}-03$ & 812 & $6.85 \mathrm{E}-03$ & 1.39 & $8.76 \mathrm{E}-03$ \\
\hline SCT2-2.20 & 20.12 & 8.081 & $7.30 \mathrm{E}-05$ & 2890 & $1.04 \mathrm{E}-03$ & 5 & $1.71 \mathrm{E}-03$ & 7.3 & $2.83 \mathrm{E}-03$ & 616 & $8.44 \mathrm{E}-03$ & 1.04 & $1.11 \mathrm{E}-02$ \\
\hline
\end{tabular}


Table C1. SPFT Test Temperature Sweep, Experimental Conditions, Dissolution Rate for SR Product Steam Reformation SPFT Test

\section{Fluidized Bed-Steam Reformer Material}

\begin{tabular}{|c|c|c|c|c|c|c|c|c|c|c|c|c|c|}
\hline Sample ID & $\begin{array}{c}\text { Dura- } \\
\text { tion } \\
\text { (days) }\end{array}$ & $\begin{array}{c}\mathrm{pH} \\
\left(23^{\circ} \mathrm{C}\right) \\
\end{array}$ & $\begin{array}{c}\text { Flow Rate } \\
\left(\mathrm{m}^{3} / \text { day }\right)\end{array}$ & $\begin{array}{c}\mathrm{Al} \\
\left(\mu \mathrm{g} \mathrm{L}^{-1}\right)\end{array}$ & $\begin{array}{l}\text { Al Rate } \\
\left(\mathrm{g} \mathrm{m}^{-2} \mathrm{~d}^{-1}\right)\end{array}$ & $\begin{array}{c}\mathrm{Si} \\
\left(\mathrm{mg} \mathrm{L}^{-1}\right)\end{array}$ & $\begin{array}{c}\text { Si Rate } \\
\left(\mathrm{g} \mathrm{m}^{-2} \mathrm{~d}^{-1}\right)\end{array}$ & $\begin{array}{c}\mathrm{Na} \\
\left(\mathrm{mg} \mathrm{L}^{-1}\right)\end{array}$ & $\begin{array}{l}\text { Na Rate } \\
\left(\mathrm{g} \mathrm{m}^{-2} \mathrm{~d}^{-1}\right)\end{array}$ & $\begin{array}{c}\mathrm{S} \\
\left(\mu \mathrm{g} \mathrm{L}^{-1}\right)\end{array}$ & $\begin{array}{c}\text { S Rate } \\
\left(\mathrm{g} \mathrm{m}^{-2} \mathrm{~d}^{-1}\right)\end{array}$ & $\begin{array}{c}\mathrm{Re} \\
\left(\mu \mathrm{g} \mathrm{L}^{-1}\right) \\
\end{array}$ & $\begin{array}{l}\text { Re Rate } \\
\left(\mathrm{g} \mathrm{m}^{-2} \mathrm{~d}^{-1}\right)\end{array}$ \\
\hline SCT2-2.21 & 21.09 & 8.094 & $5.00 \mathrm{E}-05$ & 2957 & $7.27 \mathrm{E}-04$ & 5.1 & $1.21 \mathrm{E}-03$ & 7.7 & $2.05 \mathrm{E}-03$ & 627 & $5.90 \mathrm{E}-03$ & 1.08 & 7.92E-03 \\
\hline SCT2-2.22 & 22.05 & 8.089 & $7.20 \mathrm{E}-05$ & 2852 & $9.99 \mathrm{E}-04$ & 4.7 & $1.59 \mathrm{E}-03$ & 6.6 & $2.49 \mathrm{E}-03$ & 539 & $7.00 \mathrm{E}-03$ & 0.872 & 9.09E-03 \\
\hline SCT2-2.23 & 23 & 8.094 & $7.30 \mathrm{E}-05$ & 2746 & $9.82 \mathrm{E}-04$ & 4.6 & $1.59 \mathrm{E}-03$ & 6.3 & $2.41 \mathrm{E}-03$ & 483 & $6.23 \mathrm{E}-03$ & 0.754 & $8.00 \mathrm{E}-03$ \\
\hline \multicolumn{14}{|l|}{ Cell SCT2-3 } \\
\hline SCT2-3A & - & - & - & 12 & - & 0.42 & - & 0.04 & - & 105 & - & NS & - \\
\hline SCT2-3B & - & - & - & 10 & - & 0.42 & - & 0.05 & - & 108 & - & 0.012 & - \\
\hline SCT2-3C & - & - & - & 8.8 & - & 0.21 & - & 0.04 & - & 52 & - & 0.012 & - \\
\hline SCT2-3.1 & 1 & 9.443 & $8.00 \mathrm{E}-05$ & 5292 & $2.07 \mathrm{E}-03$ & 5.62 & $2.00 \mathrm{E}-03$ & 10 & $4.22 \mathrm{E}-03$ & 134 & $8.21 \mathrm{E}-04$ & 2.25 & $2.63 \mathrm{E}-02$ \\
\hline SCT2-3.2 & 1.84 & 9.754 & $8.50 \mathrm{E}-05$ & 31379 & $1.30 \mathrm{E}-02$ & 32 & $1.28 \mathrm{E}-02$ & 69 & $3.09 \mathrm{E}-02$ & 449 & $6.83 \mathrm{E}-03$ & 0.925 & $1.14 \mathrm{E}-02$ \\
\hline SCT2-3.3 & 3.11 & 8.996 & $8.40 \mathrm{E}-05$ & 22659 & $9.28 \mathrm{E}-03$ & 24 & $9.48 \mathrm{E}-03$ & 43 & $1.88 \mathrm{E}-02$ & 270 & $3.39 \mathrm{E}-03$ & 0.394 & 4.71E-03 \\
\hline SCT2-3.6 & 10.29 & 9.049 & $8.30 \mathrm{E}-05$ & 14724 & $5.97 \mathrm{E}-03$ & 16 & $6.25 \mathrm{E}-03$ & 16 & 7.13E-03 & 124 & $6.64 \mathrm{E}-04$ & 0.043 & $3.75 \mathrm{E}-04$ \\
\hline SCT2-3.11 & 13.02 & 9.174 & $3.60 \mathrm{E}-05$ & 11398 & $2.01 \mathrm{E}-03$ & 13 & $2.18 \mathrm{E}-03$ & 9.6 & $1.83 \mathrm{E}-03$ & 258 & $1.37 \mathrm{E}-03$ & 0.491 & $2.55 \mathrm{E}-03$ \\
\hline SCT2-3.14 & 16.07 & 8.692 & $7.60 \mathrm{E}-05$ & 8396 & $3.12 \mathrm{E}-03$ & 10 & $3.46 \mathrm{E}-03$ & 38 & $1.53 \mathrm{E}-02$ & 450 & $6.15 \mathrm{E}-03$ & 1.04 & $1.15 \mathrm{E}-02$ \\
\hline SCT2-3.17 & 19.13 & 8.767 & $5.10 \mathrm{E}-05$ & 16063 & $4.01 \mathrm{E}-03$ & 17 & $4.10 \mathrm{E}-03$ & 5 & $1.35 \mathrm{E}-03$ & 1034 & $1.08 \mathrm{E}-02$ & 2.47 & $1.85 \mathrm{E}-02$ \\
\hline SCT2-3.20 & 20.12 & 8.917 & $8.40 \mathrm{E}-05$ & 13177 & $5.39 \mathrm{E}-03$ & 14 & $5.46 \mathrm{E}-03$ & 5.4 & $2.35 \mathrm{E}-03$ & 1012 & $1.73 \mathrm{E}-02$ & 2.26 & $2.77 \mathrm{E}-02$ \\
\hline SCT2-3.21 & 21.09 & 8.792 & $5.20 \mathrm{E}-05$ & 13714 & $3.48 \mathrm{E}-03$ & 15 & $3.58 \mathrm{E}-03$ & 6.4 & $1.75 \mathrm{E}-03$ & 1087 & $1.16 \mathrm{E}-02$ & 2.47 & $1.88 \mathrm{E}-02$ \\
\hline SCT2-3.22 & 22.05 & 8.846 & $8.80 \mathrm{E}-05$ & 10697 & $4.61 \mathrm{E}-03$ & 12 & $4.77 \mathrm{E}-03$ & 5.6 & $2.61 \mathrm{E}-03$ & 895 & $1.59 \mathrm{E}-02$ & 1.91 & $2.46 \mathrm{E}-02$ \\
\hline SCT2-3.23 & 23 & 8.931 & $6.10 \mathrm{E}-05$ & 11876 & $3.52 \mathrm{E}-03$ & 13 & $3.58 \mathrm{E}-03$ & 6.9 & $2.20 \mathrm{E}-03$ & 1043 & $1.29 \mathrm{E}-02$ & 2.14 & $1.90 \mathrm{E}-02$ \\
\hline \multicolumn{14}{|l|}{ Cell SCT2-4 } \\
\hline SCT2-4A & - & - & - & 7.8 & - & 0.35 & - & 0.13 & - & 111 & - & 0.012 & - \\
\hline SCT2-4B & - & - & - & 12 & - & 0.43 & - & 0.16 & - & 98 & - & 0.012 & - \\
\hline SCT2-4C & - & - & - & 11 & - & 0.57 & - & 0.2 & - & 101 & - & 0.012 & - \\
\hline SCT2-4.1 & 1 & 9.866 & $7.20 \mathrm{E}-05$ & 26191 & $9.24 \mathrm{E}-03$ & 29 & $9.68 \mathrm{E}-03$ & 57 & $2.16 \mathrm{E}-02$ & 252 & $2.39 \mathrm{E}-03$ & 0.429 & 4.42E-03 \\
\hline SCT2-4.2 & 1.84 & 9.456 & $4.80 \mathrm{E}-05$ & 27937 & $6.58 \mathrm{E}-03$ & 30 & $6.84 \mathrm{E}-03$ & 49 & $1.23 \mathrm{E}-02$ & 199 & $1.03 \mathrm{E}-03$ & 0.189 & $1.25 \mathrm{E}-03$ \\
\hline SCT2-4.3 & 3.11 & 8.92 & $7.90 \mathrm{E}-05$ & 21371 & $8.34 \mathrm{E}-03$ & 24 & $8.87 \mathrm{E}-03$ & 33 & $1.37 \mathrm{E}-02$ & 174 & $1.25 \mathrm{E}-03$ & 0.156 & $1.69 \mathrm{E}-03$ \\
\hline SCT2-4.6 & 10.29 & 8.968 & $6.50 \mathrm{E}-05$ & 15221 & $4.84 \mathrm{E}-03$ & 17 & $5.24 \mathrm{E}-03$ & 15.9 & $5.41 \mathrm{E}-03$ & 126 & $3.32 \mathrm{E}-04$ & 0.056 & 4.17E-04 \\
\hline SCT2-4.11 & 13.02 & 9.052 & $3.80 \mathrm{E}-05$ & 9929 & $1.84 \mathrm{E}-03$ & 12 & $2.00 \mathrm{E}-03$ & 9.5 & $1.86 \mathrm{E}-03$ & 513 & $3.47 \mathrm{E}-03$ & 1.15 & $6.33 \mathrm{E}-03$ \\
\hline SCT2-4.14 & 16.07 & 8.711 & $5.00 \mathrm{E}-05$ & 9022 & $2.22 \mathrm{E}-03$ & 10 & $2.36 \mathrm{E}-03$ & 35.5 & $9.40 \mathrm{E}-03$ & 638 & $6.02 \mathrm{E}-03$ & 1.58 & $1.16 \mathrm{E}-02$ \\
\hline SCT2-4.17 & 19.13 & 8.694 & $5.80 \mathrm{E}-05$ & 16197 & $4.60 \mathrm{E}-03$ & 18 & $4.71 \mathrm{E}-03$ & 5.4 & $1.59 \mathrm{E}-03$ & 1289 & $1.54 \mathrm{E}-02$ & 2.95 & $2.51 \mathrm{E}-02$ \\
\hline
\end{tabular}


Table C1. SPFT Test Temperature Sweep, Experimental Conditions, Dissolution Rate for SR Product Steam Reformation SPFT Test

\section{Fluidized Bed-Steam Reformer Material}

\begin{tabular}{|c|c|c|c|c|c|c|c|c|c|c|c|c|c|}
\hline Sample ID & $\begin{array}{c}\text { Dura- } \\
\text { tion } \\
\text { (days) }\end{array}$ & $\begin{array}{c}\mathrm{pH} \\
\left(23^{\circ} \mathrm{C}\right) \\
\end{array}$ & $\begin{array}{c}\text { Flow Rate } \\
\left(\mathrm{m}^{3} / \text { day }\right)\end{array}$ & $\begin{array}{c}\mathrm{Al} \\
\left(\mu \mathrm{g} \mathrm{L}^{-1}\right)\end{array}$ & $\begin{array}{c}\text { Al Rate } \\
\left(\mathrm{g} \mathrm{m}^{-2} \mathrm{~d}^{-1}\right)\end{array}$ & $\begin{array}{c}\mathrm{Si} \\
\left(\mathrm{mg} \mathrm{L}^{-1}\right)\end{array}$ & $\begin{array}{c}\text { Si Rate } \\
\left(\mathrm{g} \mathrm{m}^{-2} \mathrm{~d}^{-1}\right)\end{array}$ & $\begin{array}{c}\mathrm{Na} \\
\left(\mathrm{mg} \mathrm{L}^{-1}\right)\end{array}$ & $\begin{array}{l}\text { Na Rate } \\
\left(\mathrm{g} \mathrm{m}^{-2} \mathrm{~d}^{-1}\right)\end{array}$ & $\begin{array}{c}S \\
\left(\mu \mathrm{g} \mathrm{L}^{-1}\right)\end{array}$ & $\begin{array}{c}\text { S Rate } \\
\left(\mathrm{g} \mathrm{m}^{-2} \mathrm{~d}^{-1}\right)\end{array}$ & $\begin{array}{c}\mathrm{Re} \\
\left(\mu \mathrm{g} \mathrm{L}^{-1}\right) \\
\end{array}$ & $\begin{array}{l}\text { Re Rate } \\
\left(\mathrm{g} \mathrm{m}^{-2} \mathrm{~d}^{-1}\right)\end{array}$ \\
\hline SCT2-4.20 & 20.12 & 8.867 & $8.00 \mathrm{E}-05$ & 12646 & $4.95 \mathrm{E}-03$ & 14 & $5.19 \mathrm{E}-03$ & 6.5 & $2.68 \mathrm{E}-03$ & 1140 & $1.85 \mathrm{E}-02$ & 2.4 & $2.81 \mathrm{E}-02$ \\
\hline SCT2-4.21 & 21.09 & 8.786 & $5.70 \mathrm{E}-05$ & 13418 & $3.73 \mathrm{E}-03$ & 15 & $3.90 \mathrm{E}-03$ & 7.6 & $2.22 \mathrm{E}-03$ & 1192 & $1.38 \mathrm{E}-02$ & 2.54 & $2.11 \mathrm{E}-02$ \\
\hline SCT2-4.22 & 22.05 & 8.821 & $8.40 \mathrm{E}-05$ & 10791 & $4.45 \mathrm{E}-03$ & 12 & $4.55 \mathrm{E}-03$ & 6.8 & $2.96 \mathrm{E}-03$ & 960 & $1.62 \mathrm{E}-02$ & 1.96 & $2.42 \mathrm{E}-02$ \\
\hline SCT2-4.23 & 23 & 8.911 & $5.60 \mathrm{E}-05$ & 10953 & $3.03 \mathrm{E}-03$ & 12 & $3.13 \mathrm{E}-03$ & 7.6 & $2.22 \mathrm{E}-03$ & 1022 & $1.16 \mathrm{E}-02$ & 2.02 & $1.67 \mathrm{E}-02$ \\
\hline \multicolumn{14}{|c|}{ Cell SCT2-5 } \\
\hline SCT2-5A & - & - & - & 10 & - & 0.2 & - & 0.03 & - & 106 & - & 0.012 & - \\
\hline SCT2-5B & - & - & - & 8.5 & - & 0.2 & - & 0.03 & - & 103 & - & 0.012 & - \\
\hline SCT2-5C & - & - & - & 8.1 & - & 0.2 & - & 0.04 & - & 141 & - & 0.012 & - \\
\hline SCT2-5.1 & 1 & 9.756 & $1.90 \mathrm{E}-05$ & 32814 & $3.10 \mathrm{E}-03$ & 34 & $3.06 \mathrm{E}-03$ & 74 & $7.57 \mathrm{E}-03$ & 681 & $2.43 \mathrm{E}-03$ & 1.35 & $3.80 \mathrm{E}-03$ \\
\hline SCT2-5.2 & 1.84 & 9.556 & $1.01 \mathrm{E}-04$ & 26764 & $1.32 \mathrm{E}-02$ & 28 & $1.34 \mathrm{E}-02$ & 56 & $2.99 \mathrm{E}-02$ & 321 & $4.62 \mathrm{E}-03$ & 0.641 & $9.34 \mathrm{E}-03$ \\
\hline SCT2-5.3 & 3.11 & 8.899 & $9.10 \mathrm{E}-05$ & 18507 & $8.23 \mathrm{E}-03$ & 20 & 8.73E-03 & 31 & $1.50 \mathrm{E}-02$ & 169 & $1.06 \mathrm{E}-03$ & 0.216 & $2.73 \mathrm{E}-03$ \\
\hline SCT2-5.6 & 10.29 & 9.431 & $8.60 \mathrm{E}-05$ & 16017 & $6.72 \mathrm{E}-03$ & 18 & $7.41 \mathrm{E}-03$ & 20 & $8.85 \mathrm{E}-03$ & 131 & $2.82 \mathrm{E}-04$ & 0.095 & $1.05 \mathrm{E}-03$ \\
\hline SCT2-5.11 & 13.02 & 9.498 & $1.05 \mathrm{E}-04$ & 13156 & $6.73 \mathrm{E}-03$ & 15 & $7.36 \mathrm{E}-03$ & 14 & 7.59E-03 & 791 & $1.58 \mathrm{E}-02$ & 1.57 & $2.40 \mathrm{E}-02$ \\
\hline SCT2-5.14 & 16.07 & 9.792 & $8.90 \mathrm{E}-05$ & 15561 & $6.77 \mathrm{E}-03$ & 17 & $7.14 \mathrm{E}-03$ & 15 & $6.81 \mathrm{E}-03$ & 1384 & $2.52 \mathrm{E}-02$ & 2.46 & $3.20 \mathrm{E}-02$ \\
\hline SCT2-5.17 & 19.13 & 9.582 & $6.30 \mathrm{E}-05$ & 14581 & $4.52 \mathrm{E}-03$ & 16 & $4.76 \mathrm{E}-03$ & 13 & $4.30 \mathrm{E}-03$ & 1466 & $1.91 \mathrm{E}-02$ & 2.61 & $2.42 \mathrm{E}-02$ \\
\hline SCT2-5.20 & 20.12 & 9.592 & $9.30 \mathrm{E}-05$ & 11424 & $5.19 \mathrm{E}-03$ & 12 & $5.37 \mathrm{E}-03$ & 9.7 & $4.74 \mathrm{E}-03$ & 1035 & $1.91 \mathrm{E}-02$ & 1.92 & $2.61 \mathrm{E}-02$ \\
\hline SCT2-5.21 & 21.09 & 9.304 & $6.60 \mathrm{E}-05$ & 12645 & $4.07 \mathrm{E}-03$ & 14 & 4.19E-03 & 11 & $3.65 \mathrm{E}-03$ & 1065 & $1.40 \mathrm{E}-02$ & 1.99 & $1.92 \mathrm{E}-02$ \\
\hline SCT2-5.22 & 22.05 & 9.487 & $1.01 \mathrm{E}-04$ & 10177 & $5.01 \mathrm{E}-03$ & 11 & $5.27 \mathrm{E}-03$ & 8.7 & $4.59 \mathrm{E}-03$ & 784 & $1.50 \mathrm{E}-02$ & 1.49 & $2.19 \mathrm{E}-02$ \\
\hline SCT2-5.23 & 23 & 9.491 & $7.60 \mathrm{E}-05$ & 10814 & 4.04E-03 & 12 & 4.19E-03 & 8.8 & $3.52 \mathrm{E}-03$ & 746 & $1.07 \mathrm{E}-02$ & 1.4 & $1.56 \mathrm{E}-02$ \\
\hline \multicolumn{14}{|l|}{ Cell SCT2-6 } \\
\hline SCT2-6A & - & - & - & 18 & - & 0.84 & - & 0.11 & - & 28 & - & NS & - \\
\hline SCT2-6B & - & - & - & 17 & - & 0.85 & - & 0.13 & - & 32 & - & 0.012 & - \\
\hline SCT2-6C & - & - & - & 24 & - & 0.89 & - & 0.15 & - & 29 & - & 0.012 & - \\
\hline SCT2-6.1 & 1 & - & $7.20 \mathrm{E}-05$ & 35927 & $1.26 \mathrm{E}-02$ & 32 & $1.07 \mathrm{E}-02$ & 132 & $5.02 \mathrm{E}-02$ & 620 & $9.49 \mathrm{E}-03$ & 1.66 & $1.74 \mathrm{E}-02$ \\
\hline SCT2-6.2 & 1.84 & - & $7.90 \mathrm{E}-05$ & 39540 & $1.53 \mathrm{E}-02$ & 38 & $1.39 \mathrm{E}-02$ & 78 & $3.25 \mathrm{E}-02$ & 225 & $3.45 \mathrm{E}-03$ & 0.421 & $4.75 \mathrm{E}-03$ \\
\hline SCT2-6.3 & 3.11 & - & $9.20 \mathrm{E}-05$ & 28972 & $1.31 \mathrm{E}-02$ & 28 & $1.21 \mathrm{E}-02$ & 45 & $2.20 \mathrm{E}-02$ & 183 & $3.18 \mathrm{E}-03$ & 0.328 & $4.30 \mathrm{E}-03$ \\
\hline SCT2-6.6 & 10.29 & 11.061 & $9.60 \mathrm{E}-05$ & 24961 & $1.18 \mathrm{E}-02$ & 28 & $1.22 \mathrm{E}-02$ & 21 & $1.08 \mathrm{E}-02$ & 465 & $9.39 \mathrm{E}-03$ & 0.674 & $9.40 \mathrm{E}-03$ \\
\hline SCT2-6.11 & 13.02 & 11.165 & $1.17 \mathrm{E}-04$ & 22427 & $1.29 \mathrm{E}-02$ & 24 & $1.30 \mathrm{E}-02$ & 18 & $1.12 \mathrm{E}-02$ & 143 & $2.96 \mathrm{E}-03$ & 0.213 & $3.47 \mathrm{E}-03$ \\
\hline SCT2-6.14 & 16.07 & 11.037 & $9.90 \mathrm{E}-05$ & 23845 & $1.16 \mathrm{E}-02$ & 26 & $1.17 \mathrm{E}-02$ & 21 & $1.10 \mathrm{E}-02$ & 128 & $2.20 \mathrm{E}-03$ & 0.266 & $3.73 \mathrm{E}-03$ \\
\hline
\end{tabular}


Table C1. SPFT Test Temperature Sweep, Experimental Conditions, Dissolution Rate for SR Product Steam Reformation SPFT Test

Fluidized Bed-Steam Reformer Material

\begin{tabular}{|c|c|c|c|c|c|c|c|c|c|c|c|c|c|}
\hline Sample ID & $\begin{array}{c}\text { Dura- } \\
\text { tion } \\
\text { (days) }\end{array}$ & $\begin{array}{c}\mathrm{pH} \\
\left(23^{\circ} \mathrm{C}\right) \\
\end{array}$ & $\begin{array}{c}\text { Flow Rate } \\
\left(\mathrm{m}^{3} / \text { day }\right)\end{array}$ & $\begin{array}{c}\mathrm{Al} \\
\left(\mu \mathrm{g} \mathrm{L}^{-1}\right)\end{array}$ & $\begin{array}{l}\text { Al Rate } \\
\left(\mathrm{g} \mathrm{m}^{-2} \mathrm{~d}^{-1}\right)\end{array}$ & $\begin{array}{c}\mathrm{Si} \\
\left(\mathrm{mg} \mathrm{L}^{-1}\right)\end{array}$ & $\begin{array}{c}\text { Si Rate } \\
\left(\mathrm{g} \mathrm{m}^{-2} \mathrm{~d}^{-1}\right)\end{array}$ & $\begin{array}{c}\mathrm{Na} \\
\left(\mathrm{mg} \mathrm{L}^{-1}\right)\end{array}$ & $\begin{array}{l}\text { Na Rate } \\
\left(\mathrm{g} \mathrm{m}^{-2} \mathrm{~d}^{-1}\right)\end{array}$ & $\begin{array}{c}\mathrm{S} \\
\left(\mu \mathrm{g} \mathrm{L}^{-1}\right)\end{array}$ & $\begin{array}{c}\text { S Rate } \\
\left(\mathrm{g} \mathrm{m}^{-2} \mathrm{~d}^{-1}\right)\end{array}$ & $\begin{array}{c}\operatorname{Re} \\
\left(\mu \mathrm{g} \mathrm{L}^{-1}\right) \\
\end{array}$ & $\begin{array}{l}\text { Re Rate } \\
\left(\mathrm{g} \mathrm{m}^{-2} \mathrm{~d}^{-1}\right)\end{array}$ \\
\hline SCT2-6.17 & 19.13 & 10.846 & $8.10 \mathrm{E}-05$ & 22771 & $9.08 \mathrm{E}-03$ & 24 & $9.04 \mathrm{E}-03$ & 19 & $8.21 \mathrm{E}-03$ & 173 & $2.62 \mathrm{E}-03$ & 0.281 & $3.23 \mathrm{E}-03$ \\
\hline SCT2-6.20 & 20.12 & 10.972 & $1.06 \mathrm{E}-04$ & 20139 & $1.05 \mathrm{E}-02$ & 21 & $1.04 \mathrm{E}-02$ & 17 & $9.70 \mathrm{E}-03$ & 232 & $4.80 \mathrm{E}-03$ & 0.4 & $6.06 \mathrm{E}-03$ \\
\hline SCT2-6.21 & 21.09 & 10.941 & $7.00 \mathrm{E}-05$ & 20657 & $7.12 \mathrm{E}-03$ & 22 & 7.13E-03 & 18 & $6.54 \mathrm{E}-03$ & 214 & $2.90 \mathrm{E}-03$ & 0.374 & $3.75 \mathrm{E}-03$ \\
\hline SCT2-6.22 & 22.05 & 10.954 & $1.07 \mathrm{E}-04$ & 17640 & $9.29 \mathrm{E}-03$ & 19 & $9.41 \mathrm{E}-03$ & 15 & $8.52 \mathrm{E}-03$ & 281 & $6.06 \mathrm{E}-03$ & 0.504 & $7.80 \mathrm{E}-03$ \\
\hline SCT2-6.23 & 23 & 10.972 & $8.20 \mathrm{E}-05$ & 18879 & $7.59 \mathrm{E}-03$ & 20 & $7.49 \mathrm{E}-03$ & 16 & $6.78 \mathrm{E}-03$ & 331 & $5.55 \mathrm{E}-03$ & 0.651 & 7.73E-03 \\
\hline
\end{tabular}




\section{$\underline{\text { DISTRIBUTION }}$}

No. of

$\underline{\text { Copies }}$

OFFSITE

1 Westinghouse Savannah River

Company

P. O. Box 616

Aiken, SC 29802

Attn: G. G. Wicks

1 Sandia National Laboratories

1515 Eubank SE - MSIN 0748

Albuquerque, NM 87123-0748

Attn: R. D. Waters

\section{ONSITE}

3 U.S. Department of Energy

Office of River Protection

C. A. Babel, H6-60

P. E. Lamont, H6-60

B. M. Mauss, H6-60
No. of

$\underline{\text { Copies }}$

2 Fluor Federal Services, Inc.

R. J. Puigh, E6-17
R. Khaleel, E6-17

20 Pacific Northwest National Laboratory

L. M. Bagaason, K6-28

T. M. Brouns, K9-69

P. A. Gauglitz, K6-28 (3)

B. P. McGrail, K6-81 (5)

A. T. Owen, K6-81

E. M. Pierce, K6-81

E. A. Rodriguez, K6-81

H. T. Schaef, K6-81

J. L. Steele, K1-60

J. S. Tixier, K6-24

J. D. Vienna, K6-24

D. M. Wellman, K6-81

Information Release, K1-06 (2)

13 CH2M HILL Hanford, Inc.

K. D. Boomer, R1-44

K. A. Gasper, H6-03

D. W. Hamilton, H6-03 (5)

M. E. Johnson, R1-44

F. M. Mann, E6-35 (3)

R. E. Raymond, H6-22

G. W. Reddick, Jr., R1-44 